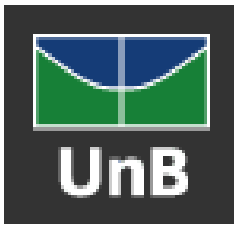

Universidade de Brasília (UnB)

Faculdade de Economia, Administração e Contabilidade (Face)

Departamento de Economia

\title{
REDE DE PESQUISA NO INSTITUTO DE PESQUISA ECONOMICA APLICADA (IPEA): UMA ANALISE DA PRODUÇÃO CIENTIFICA A PARTIR DOS TEXTOS PARA DISCUSSÃO (TD)
}

\section{Veruska da Silva Costa}

Dissertação de Mestrado apresentada ao Departamento de Economia da Universidade de Brasília (UnB), como parte dos requisitos para obtenção do grau de Mestre em Economia e Gestão do Setor Público 
Universidade de Brasília (UnB)

Faculdade de Economia, Administração e Contabilidade (Face)

Departamento de Economia

\section{REDE DE PESQUISA NO INSTITUTO DE PESQUISA ECONOMICA APLICADA (IPEA): UMA ANALISE DA PRODUÇÃO CIENTIFICA A PARTIR DOS TEXTOS PARA DISCUSSÃO (TD)}

Autor: Veruska da Silva Costa Orientadora: Dra. Andrea Felippe Cabello 
Costa, Veruska da Silva.

Rede de pesquisa no Instituto de Pesquisa Econômica Aplicada (Ipea): uma análise da produção cientifica a partir dos Textos para Discussão (TD) / Veruska da Silva Costa. - Brasília, 2016.

$\mathrm{xxi}+147 \mathrm{p}$.

Dissertação (Mestrado em Economia) - Universidade de Brasília (UnB), Brasília, 2016.

Orientadora: Dra. Andrea Felippe Cabello.

1. Rede de Pesquisa. 2. Análise de coautoria. 3. Análise de Redes Sociais. 4. Instituto de Pesquisa Econômica Aplicada (Ipea). 5. História do Pensamento Econômico Brasileiro. 6. Economia do Conhecimento. I. Título

CDU: $330.101 .8(81)$

CDD: 330.09 


\title{
Folha de aprovação
}

Dissertação de autoria de Veruska da Silva Costa, intitulada "REDE DE PESQUISA NO INSTITUTO DE PESQUISA ECONÔMICA APLICADA (IPEA): UMA ANÁLISE DA PRODUÇÃO CIENTIFICA A PARTIR DOS TEXTOS PARA DISCUSSÃO (TD)", apresentada ao Departamento de Economia da Universidade de Brasília (UnB), como parte dos requisitos para obtenção do grau de Mestre em Economia e Gestão do Setor Público, em 29/09/2016, defendida e aprovada pela banca examinadora abaixo assinada:

\author{
Profa. Dra. Andrea Felippe Cabello \\ Orientadora \\ Departamento de Economia - UnB
}
Prof. Dr. Roberto de Goes Ellery Junior
Membro da Banca
Departamento de Economia - UnB

Prof. Dr. Marcelo D. Wilbert

Membro da Banca

Departamento de Contabilidade - UnB
Profa. Dra. Adriana Moreira Amado
Membro da Banca - Suplente
Departamento de Economia - UnB

Brasília, DF
2016 
Epígrafe

"É precisamente na fronteira do conhecimento que a imaginação tem seu papel mais importante; o que ontem foi apenas um sonho, amanha poderá se tornar realidade".

Marcelo Gleiser 
Dedicatória

Aos bravos professores, pesquisadores e cientistas brasileiros. 


\section{AGRADECIMENTOS}

Agradeço à minha orientadora, profa. Dra. Andrea Felippe Cabello, pela orientação e contribuições vindas das discussões relacionadas à análise da produção científica e de redes de pesquisa.

Á Faculdade de Economia, Administração e Contabilidade (Face, da Universidade de Brasília (UnB), por toda a infraestrutura e corpo docente, em nome do prof. Dr. Roberto Ellery Júnior, Diretor da Face, e à profa. Dra. Adriana Moreira Amado, coordenadora do Mestrado em Economia e Gestão do Setor Público.

Aos presidentes do Instituto de Pesquisa Econômica Aplicada (Ipea), com quem trabalhei diretamente, Dr. Sergei Suarez Dillon Soares, Dr. Marcelo Côrtes Neri e Dr. Marcio Pochmann, pelo apoio e inspiração.

Ao Dr. Luiz Cezar Loureiro de Azeredo (Ipea), Diretor que me liberou para o mestrado, lenda viva que acompanhou todo o período de existência da série temporal de 37 anos aqui estudada, pelos comentários e apontamentos críticos à pesquisa.

Ao Dr. Fábio Ferreira Batista (Ipea), pelas inúmeras recomendações, sugestões e por todo o aprendizado proporcionado durante esse processo.

À profa. Dra. Sely Costa (UnB), mentora e orientadora, por me revelar a beleza da disciplina "Comunicação Científica", base para todos os argumentos desta pesquisa. Professora pioneira no estudo do Acesso Aberto no Brasil, agradeço imensamente o apoio e o carinho a mim sempre dispensados e as diversas orientações desde a graduação.

Ao Dr. Giovanni Pacelli Carvalho Lustosa da Costa (CGU) e Dr. Alexandre Xavier Ywata de Carvalho (Ipea-UnB), pelo apoio e comentários precisos à pesquisa, que tanto me ajudaram no desenvolvimento desta dissertação.

Aos meus amigos queridos, que prefiro não nomear, para não correr o risco de esquecer alguém, pela compreensão relativa às minhas ausências e faltas durante esses dois anos e pela parceria de sempre!

Para finalizar, mas não menos importante, muito pelo contrário, à minha família, em nome de minha mãe, Maria Luzia da Silva Costa, e meus irmãos, Roberta da Silva Costa e Otávio Augusto da Costa, pelo amor incondicional, base fundamental para que eu atingisse meus objetivos. 


\title{
REDE DE PESQUISA NO INSTITUTO DE PESQUISA ECONOMICA APLICADA (IPEA): UMA ANALISE DA PRODUÇÃO CIENTIFICA A PARTIR DOS TEXTOS PARA DISCUSSAO (TD).
}

\begin{abstract}
RESUMO
O Instituto de Pesquisa Econômica Aplicada (Ipea) é uma fundação pública vinculada ao Ministério do Planejamento. Suas atividades de pesquisa e planejamento apoiam o governo na implementação de políticas públicas. Sabe-se que estudar a constituição, a dinâmica e o funcionamento da comunicação cientifica torna-se estratégico para países como o Brasil. Essa é uma importante ferramenta de estudo e análise, que pode contribuir para que possamos nos deslocar da chamada zona periférica da ciência, onde estamos localizados hoje, para a zona central da ciência. Estudos dessa natureza são relevantes para países em desenvolvimento como o Brasil, pois desnuda as relações entre "produtos e insumos" da pesquisa científica no mundo e demonstram como países desenvolvidos, que detém o fluxo da comunicação científica no mundo, têm se comportado. O trabalho analisa a produção do Ipea com base na série periódica "Textos para Discussão" (TD). Este trabalho teve como objetivo o estudo da série periódica em relação a três aspectos: aspectos formais; aspectos quantitativos e aspectos qualitativos. Este estudo caracterizase pela utilização do método quantitativo descritivo, e teve a realização de entrevistas com o objetivo de melhorar os resultados em termos qualitativos. O estudo baseou-se na análise da série temporal, construída ao longo de 37 anos e na análise de coautoria, com base na Análise de Redes Sociais (ARS). Os resultados obtidos demonstraram que a série temporal pode ser utilizada pelo Ipea como um indicador de produção, de forma a entender o seu desempenho ao longo dos 37 anos de existência da série. O Ipea, ao observar os picos e quedas de sua produção, a partir desta variável que nomeamos Produção Anual de Textos para Discussão (PATD), pode entender melhor como o seu desempenho é influenciado por outras variáveis e agir corretivamente. Os resultados relacionados a análise formal da série fornecem um conjunto de características comuns relacionadas a periódicos que podem auxiliar o Ipea no aprimoramento deste importante canal de comunicação. Como resultado da análise de coautoria, o estudo apresenta os resultados que se inserem no escopo de estudos e pesquisas que utilizaram a Análise de Redes Sociais (ARS) aplicada à área de Ciência da Informação, mais especificamente à Comunicação Científica, e apresenta os resultados relacionados às redes de colaboração em pesquisa ou colaboração científica, a partir de um grupo central de autores vinculados ao Instituto de Pesquisa Econômica Aplicada (Ipea).
\end{abstract}

Palavras-chave: 1. Rede de Pesquisa. 2. Análise de coautoria. 3. Análise de Redes Sociais (ARS). 4. Instituto de Pesquisa Econômica Aplicada (Ipea). 5. História do Pensamento Econômico Brasileiro. 6. Economia do Conhecimento. 


\title{
RESEARCH NETWORK IN THE INSTITUTE FOR APPLIED ECONOMIC RESEARCH (IPEA): A PRODUCTION SCIENTIFIC ANALYSIS FROM THE DISCUSSION PAPERS (TD)
}

\begin{abstract}
The Institute for Applied Economic Research (Ipea) is a public foundation linked to the Ministry of Planning. Its research activities aid the government in planning and implementing public policies. It is known to study the formation, dynamics and functioning of scientific communication is strategic for countries like Brazil. This is an important study and analysis tool that can help us to move in the so-called peripheral zone of science, where we are located today to the central area of science. Such studies are relevant to developing countries such as Brazil, as denuded relations between "products and inputs" of scientific research in the world and demonstrate how to developed countries, which holds the flow of scientific communication in the world, have behaved. The paper analyzes the production of IPEA based on periodic series "Discussion paper". This work aimed to study the periodic series on three aspects: formal aspects; quantitative aspects, and qualitative aspects. This study is characterized by the use of descriptive quantitative method, and had interviews with the aim of improving the results in qualitative terms. The study was based on analysis of time series, built over 37 years and co-author of the analysis, based on the Social Network Analysis (SNA). The results showed that the time series can be used as an indicator IPEA production in order to understand its performance over the 37 years of the existence of the series. Ipea can to observe the peaks and troughs of its production from this variable that we named Annual Production of Texts for Discussion (PATD), and can better understand how their performance is influenced by other variables and act correctively. The results related to formal analysis of the series provide a common set of characteristics related to journals that can help the IPEA in the improvement of this important channel of communication. As a result of co-authorship analysis, the study presents the results fall within the scope of studies and research using the Social Network Analysis (SNA) applied to the area of Information Science, specifically the Scientific Communication, and presents the results related collaborative networks for research or scientific collaboration, from a core group of authors linked to the Institute for Applied Economic Research (Ipea).
\end{abstract}


OBJETO DE ESTUDO

PERGUNTAS DA PESQUISA

OBJETIVO GERAL

OBJETIVOS ESPECÍFICOS

PREFÁCIO

1 INTRODUÇÃO

2 REFERENCIAL TEÓRICO 22

3 METODOLOGIA 50

4 RESULTADOS 54

4.1 RESULTADOS: DESCOBERTA DA SÉRIE TEMPORAL 54

4.2 RESULTADOS: ANÁLISE DA SÉRIE TEMPORAL 56

4.3 RESULTADOS: ANÁLISE POR PERÍODOS DE GESTÃo 4.4 RESULTADOS: ANÁLISE POR PERÍODOS DE GESTÃO INTERNA 66 4.5 RESULTADOS: ANÁLISE POR ÁREA TEMÁTICA 68

4.6 RESULTADOS: ANÁLISE POR TIPO DE AUTORIA 73

$\begin{array}{lr}\text { 4.7 RESULTADOS: ANÁLISE FORMAL } & 81\end{array}$

5. ANÁLISE DE REDES SOCIAIS (ARS) 85

5.1 REFERENCIAL TEÓRICO

5.6 RESULTADOS: ANÁLISE DA REDE IPEA 91

$\begin{array}{lr}\text { 6. CONCLUSÕES } & 137\end{array}$

REFERÊNCIAS BIBLIOGRÁFICAS

$\begin{array}{lr}\text { APÊNDICES } & 148\end{array}$

APÊNDICE A: TABELA DE CODIFICAÇÃO DE AUTORES 148 


\title{
OBJETO DE ESTUDO
}

\author{
A SÉRIE PERIÓDICA “TEXTOS PARA DISCUSSÃO”(TD) DO IPEA.
}

\section{PERGUNTAS DA PESQUISA}

1) Como os dados de um periódico nacional de 37 anos podem revelar uma "variável" importante do ponto de vista da análise do desempenho do Ipea? Como encontrar padrões não aleatórios na série temporal TD do Ipea? É possível escrever uma "função matemática perfeitamente determinada", como lei de formação da série temporal Yt? É possível calcular o valor assumido por Y em consequência do valor que $\mathrm{X}$ assumiu $(\mathrm{Y}=\mathrm{f}(\mathrm{x}))$ ? Quais outras variáveis podem ser criadas e coletadas a partir da série periódica "Textos para Discussão (TD)" do Ipea, que podem fornecer dados para avaliações de correlação? A variável observada pode ser considerada um "indicador de produção" do Ipea? Pode-se apresentar a série temporal como uma "proxy" para o Ipea?

2) Como se dá a avaliação de um periódico em relação as suas características formais? É possível que um periódico brasileiro, não reconhecido pela comunidade acadêmica e que teoricamente não pertence ao conjunto de periódicos validados internacionalmente pelas principais editoras científicas mundiais, reúna características até então não descritas? Analisar o TD de acordo com as suas características de forma e indicadores de qualidade pode contribuir em futuras decisões sobre o aperfeiçoamento desse canal de comunicação?

3) É possível fazer uma análise quantitativa, referente às questões de autoria, na série TD do Ipea? Como ocorreu a publicação dos resultados de estudos e pesquisas no que se refere às múltiplas formas de coautoria adotadas? Publicar em grupo ou sozinho? A tendência mundial observada na literatura científica, por diversos autores, relacionada ao aumento do $\mathrm{n}^{\mathbf{0}}$ de trabalhos publicados em multiautoria, também pode ser observada na série periódica Texto para Discussão do Ipea? E a tendência observada na literatura científica mundial, em diversas áreas do conhecimento, quanto à tendência de redução do número de trabalhos em autoria única? É possível fazer uma análise quantitativa referente à temática dos trabalhos publicados? Como ocorreu a publicação na série em relação à temática dos trabalhos?

4) E possível realizar uma estudo das redes de pesquisa do Ipea com base na análise de coautoria da série "Textos para Discussão (TD)"? Como se pode, a partir de uma série temporal de 37 anos, estudar os grafos de uma grande rede de colaboração? 


\section{OBJETIVO GERAL}

Analisar a série periódica "Textos para Discussão (TD) do Ipea" em relação a três aspectos: aspectos formais; aspectos quantitativos e aspectos qualitativos.

\section{OBJETIVOS ESPECÍFICOS:}

1) Organizar e analisar os dados quantitativos da série, ao longo dos seus 37 anos de existência. Cruzar os dados quantitativos da série, reorganizados por ano, com determinados fatos históricos do contexto econômico-político nacional. Buscar encontrar padrões não aleatórios na série temporal, com foco na variável de interesse, a partir dos diferentes fatos observados. Buscar a observação detalhada deste comportamento passado, que poderá permitir fazer previsões sobre o futuro, orientando a tomada de decisões. Verificar se os dados crescentes observados na publicação da série periódica, do ponto de vista do desempenho do Ipea nos últimos 37 anos, podem ser explicados a partir da "tendência mundial de aumento observada na produção científica". Verificar se outras variáveis internas do Ipea podem ter influenciado (KING, 2004); Registrar os dados relativos a outras variáveis internas que podem ter influenciado esse crescimento verificado na produção do Ipea, tais como: $\mathrm{x} 1=$ número de pesquisadores; $\mathrm{x} 2=$ capital intelectual humano total; $\mathrm{x} 3=$ programas de mestrado e doutorado para pesquisadores e técnicos de desenvolvimento; programas de bolsas de pesquisa para graduação, mestrado e doutorado, como PNPD; $\mathrm{x} 4=$ volume do conhecimento produzido; $\mathrm{x} 5=$ concursos realizados ao longo dos anos.

2) Recolher dados sobre a variável observada e verificar se a relação é sempre perfeita,e se podemos escrever uma "função matemática perfeitamente determinada", como lei de formação da série temporal Yt. Calcular o valor assumido por $\mathrm{Y}$ em consequênciado valor que a variável " $\mathrm{X}$ " assumiu ( $\mathrm{Y}=\mathrm{f}(\mathrm{x})$ ); Selecionar a variável $\mathrm{X}$ para traçar a reta $\mathrm{AB}$.

3) Analisar os TDa partir dos seus aspectos formais e de qualidade,a fim decaracterizá-lo de acordo com a literatura cientifica sobre o tema. Levantar as características próprias do TD como canal de comunicação científica para analisar suas características como periódico, com o objetivo de fornecer informações relevantes para o aperfeiçoamento desse importante canal de comunicação brasileiro;

4) Classificar a série TD do Ipea, 2.203 títulos, com o objetivo de gerar novos dados para a análise da Rede do Ipea, do ponto de vista dos assuntos pesquisados. Utilizar para a classificação dos dados o Sistema de Classificação do Journal of Economic Literature (JEL). A classificação temática objetiva a identificação dos temas mais pesquisados pelo Ipea e a publicação gráfica desses dados da série, ano a ano, e por períodos de gestão no Brasil. Publicar os resultados da classificação e a Cobertura Temática da série periódica Textos para Discussão (TD) de forma gráfica, visto que nenhum dos dois trabalhos anteriores a esse, O TD 1000 (2004) e o TD 2000 (2014), que também analisaram os TD, publicaram somente informações textuais. 
5) Gerar novos dados para a série, a partir da Análise de Coautoria de cerca de 1.237 trabalhos publicados em coautoria, de um total de $\mathbf{2 . 2 0 3}$ trabalhos publicados na série periódica "Textos para Discussão (TD)" do Ipea. Do ponto de vista da Comunicação Cientifica, (HUDSON 1996;Abt 2007;NABOUT et al., 2014), objetiva verificar se há um aumento no número de trabalhos em coautoria e multiautoria na série ao longo dos seus 37 anos de existência, confirmando ou rejeitando a tendência "publish/perish, verificada em muitos periódicos científicos no mundo e confirmada por inúmeras pesquisas.

6) Analisar a Rede do Ipea a partir da análise de coautoria na série periódica TD do Ipea. O caráter longitudinal da Rede, 37 anos, propiciará futura análise da evolução estrutural da rede, tendo em vista a riqueza da base para pesquisas na área de ARS. Nesse sentido, objetiva-se disponibilizar a base de dados da Rede do Ipea para a colaboração do estudo de ARS no Brasil. Realizar a análise da Rede a partir da lógica de sistemas, do funcionamento das partes que estão interconectadas como um grande circuito, por períodos. A análise de redes de coautoria, inédita para a série, do ponto de vista da ARS; objetiva revelar a inédita Rede de pesquisa de Ipea. Objetiva explorar o banco de dados construído por meio da estruturação dos dados em matrizes construídas no Excel e migradas para o software UCINET; classificar a Rede quanto às relações entre autores, como egocêntricas (puras e interconectadas) ou sociocêntricas; descrever o máximo da rede a partir dos grafos gerados, com foco inicial na descrição de grandes componentes, blocos, subgrafos máximos, principais vértices, cutpoints, cliques. Calcular a densidade e o grau médio da Rede; a centralidade de grau e de intermediação dos atores em todos os períodos. 


\section{PREFÁCIO}

\section{Aprender a pensar com a história da ciência}

Durante o período de realização do mestrado, uma estratégia foi estudar a história da ciência, desde os primórdios, sob vários aspectos. Interessava os mais variados canais de informação, dentre esses, livros, teses e séries científicas. Ao ter acesso a diversos vídeos sobre como pesquisadores de destaque, e que coordenam laboratórios de pesquisa no mundo todo, fazem ciência e como são os métodos utilizados por eles nas pesquisas, foi possível pensar na pesquisa de forma racional, no que diz respeito à escolha dos métodos. Um relato sobre uma pesquisa em inteligência artificial, mais especificamente visão computacional, mostrou como seria possível usar a cabeça para se ter uma bela ideia de pesquisa. A pesquisadora chefe foi relatando como a imaginação era importante para superar os resultados negativos, muitas vezes encontrados, e dar continuidade a pesquisa por novos caminhos.

Um documentário de 2010, chamado "Gênios da Grã-Bretanha", ou "Genius of Britain", em seu título original, foi muito importante nesse processo. Buscou-se inspiração em histórias como a de Christopher Wren, que pertencia ao "Colégio Invisível" por volta de 1664. Sua experiência conhecida como "O experimento do Baço de Wren", estabeleceu a noção de que as superstições podem ser tratadas com a experiência prática. Outros cientistas notáveis, como Robert Hooke e Robert Boyle, que se juntaram para construir a primeira bomba de vácuo britânica, apresentada para a Royal Society em 1661, demonstraram que unidos os dois eram mais fortes. As ideias de um, eram colocadas em prática pelo outro.

Outra história que chamou a atenção foi a de Isambard Brunel, que nasceu em 1806. Brunel foi responsável pela construção de grandes navios britânicos, dentre eles o SS Great Britain. O método de pesquisa de Brunel estava baseado em anotações detalhadas que este fazia sobre o desempenho das hélices. Brunel variava o tamanho das hélices e anotava os diferentes desempenhos em função do tamanho testado. Essas anotações sistemáticas e o método descrito em relação aos processos adotados, de experimentar, testar e aperfeiçoar; fizeram com que Brunel fosse considerado por muitos o criador da pesquisa e do desenvolvimento, para estes, nascia aqui a engenharia moderna.

Dentre todos os belos exemplos, se destaca o grande gênio de todos os tempos, Isaac Newton. Seu exemplo nos mostrou a importância da matemática para a comprovação das teorias e detalhes relacionados à comunicação científica desde os primórdios da ciência. Nascido em 1643, chegou a Cambridge por volta de 1661. Dizem que foi por volta de 1664 que Newton começou a se perguntar se a "matemática poderia explicar todos os fenômenos naturais". No final da década de 60, por volta de 1669, Newton apresenta sua teoria sobre a Luz à Royal Society. Mesmo confessando ter partido de estudos de Hooke, Newton não conseguiu que suas ideias fossem aceitas. Newton voltou para Cambridge, rompendo completamente as relações com a Royal Society. Passados cerca de 20 anos, Newton ainda estava isolado em Cambridge, quando um jovem de 22 anos, um cientista chamado Edmund Halley, pertencente a Royal Society, convenceu-se que apenas ele poderia ajudá-lo com os cálculos matemáticos. Autor da obra "Mapa das estrelas do hemisfério sul", Halley achava que apenas Newton poderia ajudá-lo a calcular a rota do cometa que depois levaria seu nome. Halley procurou Newton, em Cambridge, em 1684, e o desafiou a explicar o funcionamento dos astros. Desafiado e instigado por 
pensar que Hooke poderia estar prestes a fazer a descoberta, apenas três anos depois, em 1687, Newton apresenta ao mundo sua obra prima, "Principio Matemático de Newton". Inocentado de todas as acusações anteriores, Newton é eleito presidente da Royal Society, colocando a matemática como chave para toda a ciência.

Estava claro neste exemplo, que a seletividade e os "egos" da ciência, por vezes, a fazia errar. Nesse episódio de Newton, foi possível ver que a "ciência" nada podia fazer quanto ao conhecimento científico matematicamente comprovado. $\mathrm{O}$ caráter exato e preciso da matemática, dava às teorias o aval que precisavam para serem aceitas pela academia científica. A forma como a evolução da informação científica se dava no contexto da Comunicação Científica chamou atenção. Descobrir como os primeiros pesquisadores criaram os métodos, principalmente os astrônomos, que faziam coletas de dados em sofridas expedições, durante longos anos, para tentarem comprovar ou refutar, por exemplo, a teoria da relatividade de Einstein, mostrou o caráter cumulativo da ciência. 


\section{INTRODUÇÃO}

\subsection{A "Produção Anual de Textos para Discussão" (PATD)}

No decorrer deste trabalho pretende-se demonstrar como e porque os dados internacionais que avaliam a ciência, os dados de citação, mostraram-se mais frágeis para esta pesquisa do que os "dados de uma série temporal" no Brasil. No início desta pesquisa, ao trabalhar com uma série de dados da produção científica internacional, deparou-se com a realidade sobre os dados que tinham sido coletados. Como os dados de citação são baseados em "metodologias ainda questionáveis" por muitos autores (VELHO, 2014), optou-se por escolher para este estudo, dados mais robustos e confiáveis do ponto de vista metodológico. Dessa forma, ao final, ter-se-ia resultados cientificamente mais robustos. A partir desta constatação, de que os dados sobre a questão do "Fator de Impacto" não poderiam fornecer o que se buscava, saiu-se em busca de um conjunto de dados que pudesse ser considerado "seguro".

Ao coletar os dados da "série temporal" construída a partir da publicação dos Textos para Discussão (TD) do Ipea, nos últimos 37 anos, foi possível observar o comportamento da variável Y ao longo dos anos, e percebemos que uma explicação possível poderia ser dada aos fenômenos observados, com base em sua linha de tendência.

Gráfico 1: Produção Anual de Textos para Discussão do Ipea (PATD) e sua Linha de Tendência (linear)

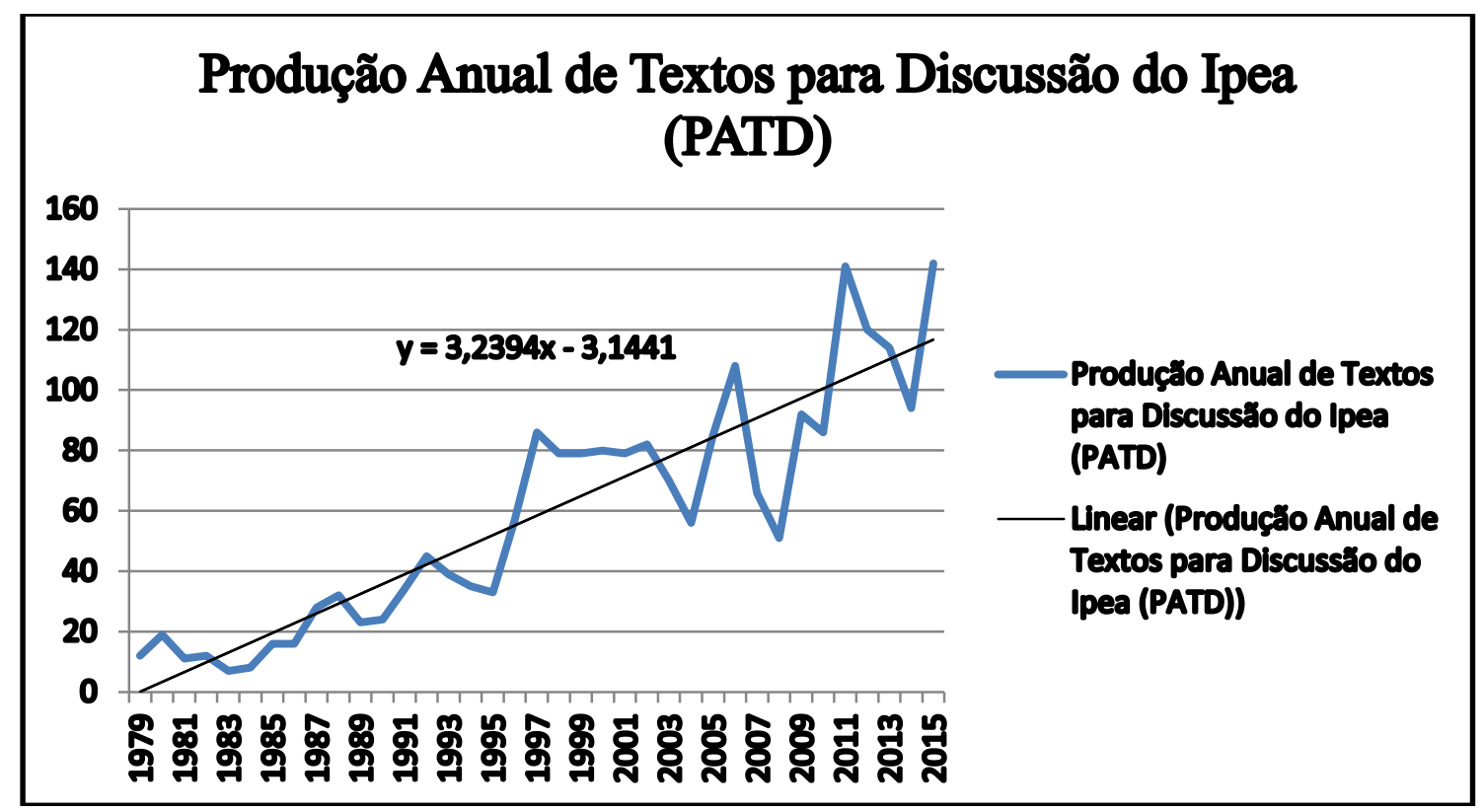

Nota: Elaboração da autora 
Pode-se dizer que a produção anual de Textos para Discussão (TD) do Ipea é determinada pela soma dos de todos os TD produzidos nos 12 meses do ano. Pode-se então escrever a seguinte função matemática, como lei de formação da série temporal $\mathrm{Yt}_{\mathrm{t}}$

\section{$\mathbf{Y} \mathbf{t}=\mathrm{Jant}+\mathrm{Fevt}+$ Mart + Abrt + Mait + Jut + Jult + Agot + Sett + Outt + Novt + Dezt}

Observou-se que essa variável Y, que nomeamos como PATD, "Produção Anual de Textos para Discussão", sofria a influência de outras variáveis, que a fazia ter quedas e picos em todo o período. Caberia à pesquisa buscar as explicações que estariam relacionadas a esse aumento e diminuição da produção do Ipea ao longo dos anos. Foi assim que se encontrou, como um dos resultados desta pesquisa, no âmbito do Mestrado em Economia e Gestão do Setor Público, essa importante Proxy de pesquisa para o Ipea. Objetivamente, percebeu-se que, a priori, poder-se-ia apresentar como um dos resultados diretos desta pesquisa, a utilização desta "série temporal" como forma do Ipea entender o seu desempenho ao longo dos 37 anos da existência da série. O Ipea, ao observar os picos e quedas de sua produção, a partir desta variável PATD, poderia entender melhor como o seu desempenho é influenciado por outras variáveis e agir corretivamente.

A série periódica "Textos para Discussão (TD) nunca havia sido estudada até então do ponto de vista proposto pela presente pesquisa. Conforme visto, adotá-la como objeto de estudo foi uma escolha acertada em vários aspectos. Este canal de comunicação, que estava sendo desprezado pela Cientometria, pois não era um periódico científico em seu significado tradicional, forneceu um resultado até então ainda não explorado por ela.

Em relação à análise formal do TD, ao se trabalhar com a produção do Ipea para a construção do Repositório do Conhecimento do Ipea (RCIpea), em 2012, perguntou-se sobre a importância dos Textos para Discussão (TD) como canal de comunicação cientifica. Será que seria possível classificá-lo como periódico? E como periódico científico? Sabia-se que muitos pesquisadores do Ipea consideram os Textos para Discussão (TD) um canal de comunicação para publicação de "discussão preliminar de resultados de pesquisa". Poderiam ser classificados então como "working papers" ou préprints? Quais características diferenciavam a série periódica TD do Ipea?

Ao analisar a pontuação do TD no Sistema Qualis, um fato curioso chamou a atenção. A pontuação do TD para área de "Economia" era 0 (zero), mas para área "Interdisciplinar", era B1. Isso poderia significar que os professores e pesquisadores vinculados aos programas de pós-graduação da Economia não consideravam o TD, um canal de comunicação adequado para publicação de resultados de pesquisa. Por outro lado, se o TD estava avaliado em B1 no Sistema Qualis, significava que já havia sido informado por um outro grupo de professores, pertencentes a outras áreas do conhecimento, em seus relatórios dos Programas de Pós-Graduação à Capes, como sendo um canal de comunicação escolhido para a publicação de resultados de suas pesquisas.

Para entender como eram avaliados os canais de comunicação científica tradicionais, aqueles que provavelmente professores e pesquisadores de Economia escolhem para publicar seus resultados de pesquisa, decidiu-se verificar os principais índices mundiais de avaliação da ciência. Consultou-se, por exemplo, o Science Citation Index (SCI), que é compilado desde 1963 pela empresa americana Institute for Scientific Information (ISI); o Scimago, onde verificou-se o posicionamento das principais revistas brasileiras e latinoamericanas em Economia e áreas afins; e ainda o atual e relevante serviço de Métricas do 
Google Acadêmico, Google Scholar Metrics, serviço vinculado a maior empresa da atualidade e uma das maiores gigantes no quesito "banco de dados" de busca e citação de informação cientifica no mundo.

Ao verificar a posição dos melhores periódicos de Economia brasileiros, no contexto mundial da avaliação da ciência disponibilizados pela SCI, os resultados eram muito baixos. Se comparado aos países da América Latina, o Brasil ocupa sempre as primeiras posições. Mas se comparado aos países do mundo, nossa contribuição a ciência torna-se quase imperceptível. Ficava claro que, mesmo para os melhores periódicos nacionais na área, não era nada fácil competir com os periódicos internacionais consagrados. Será que esses periódicos brasileiros chegarão um dia a posições mais representativas no ranking mundial da ciência?

Nesse contexto, perguntava-se se os Textos para Discussão (TD) do Ipea, como principal canal de comunicação do Ipea para publicação dos resultados de seus estudos e pesquisas, deveriam seguir de alguma forma esses "critérios de qualidade" que fazem dos periódicos científicos canais de comunicação valorizados. Complementarmente, sabendo-se que os TD são uma publicação periódica vinculada a um instituto de pesquisa pertencente à Administração Pública Brasileira (APB), por esta razão, possui evidentemente outros atributos e características em função dos objetivos que persegue em razão de sua missão institucional. Percebeu-se que tais atributos, se elencados e organizados, poderiam auxiliar no entendimento desta importante série periódica brasileira.

Ao pesquisar o impacto de alguns estudos e pesquisas publicados pela série periódica Textos para Discussão (TD) do Ipea, observou-se que muitos deles tinham sim impacto na produção científica brasileira. Por meio dos mecanismos de busca do Google Acadêmico, verificamos que alguns trabalhos do Ipea tinham um número de citações muito superior a alguns títulos de artigos apontados pelo próprio "Google Metrics" como tendo maior impacto, por pertencerem a determinados periódicos. Os dados de citação foram recolhidos e organizados para futuros estudos sobre o impacto da PATD.

Tinha-se então uma série de perguntas sobre o este rico objeto de estudo. O objetivo desta pesquisa é então analisar a série periódica Textos para Discussão do Ipea (TD), com foco inicial em aspectos ainda não incluídos e explorados nos dois trabalhos anteriores a este, o TD 1000 e o TD 2000, publicados pelo próprio Ipea em 2004 e 2014.

Outro fato que chamou a atenção sobre os Textos para Discussão (TD) do Ipea, diz respeito à ponte que se pode fazer por meio da análise da série temporal, que se localiza entre a Cientometria, área que "mede a ciência", e a Econometria, área que mede a Economia. Escolher a série periódica TD do Ipea mostra novos caminhos para ambos os ramos da ciência. Este trabalho inova ao buscar no "desconhecido", ou no "nãoreconhecido" periódico nacional, respostas para questões ligadas à Econometria e à Cientometria ou Bibliometria.

Tais trabalhos que antecederam esta pesquisa não "enxergaram" os dados quantitativos da série do ponto de vista da "Proxy de desempenho" que aqui foram inicialmente explorados e não utilizaram essa rica fonte de dados para análise de redes a partir das relações de coautoria. Ambos os dados, a série temporal, que se apresenta como forma de medir o desempenho do Ipea, e os dados de coautoria, que foram utilizados para análise 
da rede, são robustos o suficiente para serem usados com segurança, e, no entanto, não haviam sido explorados.

Estava escolhido o "objeto de estudo". Era sabido que, se se quisesse dizer algo na pesquisa, que pudesse vir a ser considerado um dia, a escolha do "objeto de estudo" deveria ser muito bem-feita. Uma série temporal de 37 anos tem por si só muito valor para a Economia e para a Econometria. Para a Bibliometria ou Cientometria, escolher um periódico brasileiro, até então desprezado pela área, foi um desafio.

\subsection{A Comunicação Científica como força motora das Redes de pesquisa}

A Comunicação Científica é a força motora das redes de pesquisa. Já a alma da ciência está naqueles que possuem cérebro, que pensam e formulam perguntas de pesquisa todos os dias, em diversos lugares do mundo. São atores em uma grande rede mundial. O grafo abaixo, figura 2, é um dos resultados da pesquisa feita pela OCDE (2010), na área de Análise de Redes Sociais (ARS), a partir da análise de coautoria, no contexto do Sistema de Patentes. Pode-se ver o Brasil e outros importantes países em um típico grafo da rede mundial que se estabelece a partir das relações de coautoria de patentes existentes e mapeadas entre estes países.

\section{Figura 1 - Figura da OCDE que mostra a rede que se formou a partir do Sistema de Patentes no mundo, em 2008}

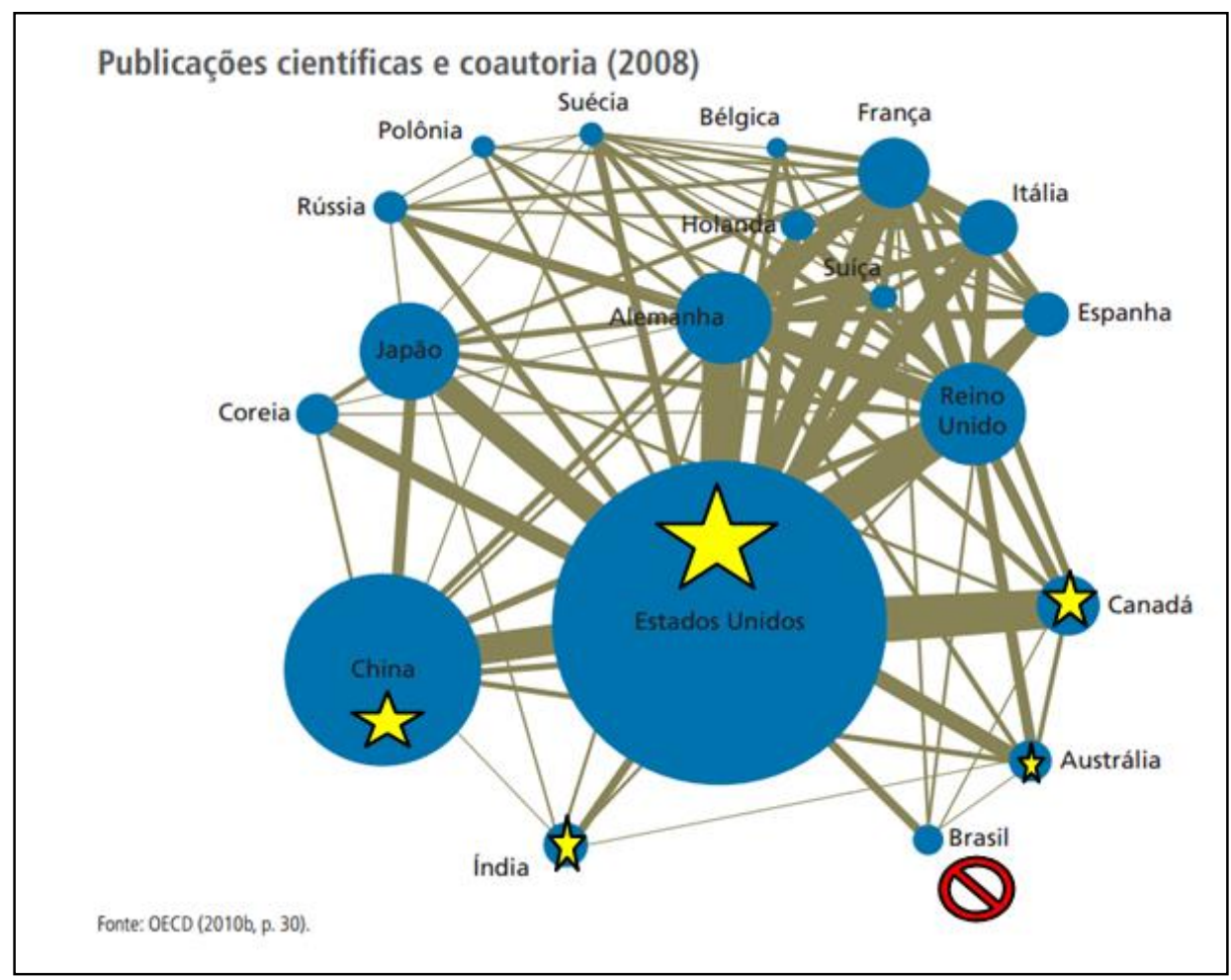

Fonte: OCDE (2010b, p.30)

A partir deste exemplo, começou-se a pensar sobre a questão das redes de coautoria e entender os diferentes tamanhos atribuídos a cada um dos atores (países) no grafo. Percebeu-se, mesmo antes de conhecer a teoria de ARS, as diferentes posições de cada 
um em relação à rede; os laços fortes, fracos e ausentes existentes entre os pares de atores; as posições de centralidade de alguns países; percebeu-se a existência dos cutpoints, que são atores que ligam blocos na rede e o número de ligações entre cada um deles.

Conforme se pode ver a partir do grafo acima, próximos ao Brasil estão os Estados Unidos, a Austrália, o Canadá e a Índia. O Brasil está ligado a cinco países, mas não à Índia. O laço mais forte que o Brasil estabeleceu foi com os Estados Unidos. Como é possível verificar, o Brasil também está ligado ao Reino Unido e à França, que parecem estar em outro bloco da rede, distantes, mas ligados ao Brasil por meio de ligações mais fracas do que o laço que o Brasil estabeleceu com os Estados Unidos. Os outros dois países, Austrália e Canadá, também estão ligados ao Brasil, mas por laços ainda mais fracos, se comparados aos que ligam o Brasil ao Reino Unido e à França.

O trabalho original da OCDE (2010b) mostra o aumento das publicações de patentes em coautoria no mundo, em uma década, por meio de grafos produzidos de 1998 e 2008. Em 1998, o Brasil tinha apenas três ligações, ou linkages, com três países nessa rede. Ligavase aos Estados Unidos, ao Reino Unido e à França. Em 2008 apareceram mais dois laços com dois países, Austrália e Canadá. A Índia, que parece integrar o polo da rede onde o Brasil se encontra, continua sem laços com o Brasil. Voltar-se-á a este gráfico na conclusão da pesquisa, a priori percebeu-se que este grafo está conectado, pois todo par de pontos está conectado por um caminho e que não existem subgrafos ou clusters neste grafo, ou seja, um agrupamento "paralelo" de atores na rede.

Nesse exemplo, viu-se como a análise de redes, a partir da análise de coautoria, traz informações estratégicas sobre as relações entre os países e como fica perceptível a frequência de colaboração entre os países e a centralidade de determinados países em relação a outros. A transferência de conhecimentos, que ocorre a partir dos diversos canais de Comunicação Científica, é fundamental para o desenvolvimento da ciência e, por essa razão, podemos considerá-la um de seus principais elementos.

Estudar a constituição, a dinâmica e o funcionamento da Comunicação Cientifica tornase estratégico para países como o Brasil. Essa é uma importante ferramenta de estudo e análise, que pode contribuir para que o Brasil possa se deslocar da chamada zona periférica da ciência, onde está localizado hoje, para a zona central da ciência. Estudos dessa natureza são relevantes pois desnudam as relações entre "produtos e insumos" da pesquisa científica no mundo e demonstram como países desenvolvidos, que detém o fluxo da comunicação científica no mundo, têm se comportado.

Esta pesquisa insere-se no escopo de estudos e pesquisas que utilizaram a Análise de Redes Sociais (ARS) aplicada à área de Ciência da Informação, mais especificamente à Comunicação Científica, e apresenta os resultados relacionados às redes de colaboração em pesquisa ou colaboração científica, a partir de um grupo central de autores vinculados ao Instituto de Pesquisa Econômica Aplicada (Ipea).

Destaca-se o fato de que os resultados apresentados nesta pesquisa são oriundos de uma proposta de estudo, inédita e original, de como vimos a aplicação de ARS para análise da rede de pesquisa do Ipea com base na análise das relações de coautoria estabelecidas no decorrer de 37 anos de existência da série temporal. O objeto de estudo desta pesquisa, os "Textos para Discussão" (TD), que publica os principais "resultados das atividades de 
pesquisa" do Ipea, mostrou-se muito útil no decorrer da pesquisa que diz respeito ao estudo da Rede Ipea.

Do ponto de vista da análise de coautoria, o objeto de estudo mostrou-se um dos mais ricos para o entendimento da Rede de Pesquisa do Ipea, seus principais atores e componentes. Para se ter uma ideia, o banco de dados construído e os resultados da pesquisa abrem caminhos para uma análise longitudinal das Redes, onde será possível descrever a evolução estrutural da Rede, por exemplo, em 37 grafos. A análise longitudinal permite, por exemplo, entender as mudanças ocorridas na Rede de Pesquisa do Ipea ao longo dos anos, destacando os principais vértices que foram ou ainda são importantes para o Ipea. A análise estrutural da rede objetiva estudar os papéis e posições dos autores na rede, e para tanto precisa recorrer a teoria dos grafos (caminho geodésico), que fornece a base matemática para determinação de padrões e visualização das redes e das matrizes que devem ser utilizadas para os cálculos computacionais.

Interessante acompanhar os pesquisadores, que no passado tiveram um papel importante (cutpoints), do ponto de vista da composição da Rede, que com o passar dos anos podem desaparecer da Rede e levar consigo atores (nós) que estão ligados à Rede somente a partir desses atores, que desempenham o papel de ligar blocos à rede.

O estudo identificou redes de colaboração em pesquisa, entre pesquisadores do Ipea, que estabeleceram relações de coautoria entre si e com outros pesquisadores do país e do exterior. Os vértices da rede de colaboração, também chamados de nós, ou simplesmente atores, são esses autores que publicaram trabalhos, em coautoria, na série periódica "Textos para Discussão (TD)" do Ipea. Os dados de coautoria, ao contrário dos dados de citação, são considerados dados confiáveis para análise de redes sociais. Não há como ter dúvidas sobre a relação estabelecida, pois ela está impressa na autoria dos trabalhos.

Por meio do levantamento das colaborações em pesquisa foram identificadas as possíveis relações de união e grau de colaboração dos membros dessa rede. Os resultados apontam a relevância do estudo de redes de coautoria no estudo da produção científica de um grupo de pesquisa. A rede é formada principalmente por: membros vinculados ao Ipea (Ipeanos); pesquisadores visitantes; bolsistas e assistentes de pesquisa. Compõem a rede, além dos Ipeanos, professores e pesquisadores de Institutos de Pesquisa e Instituições de Ensino Superior (IES) e membros da Administração Pública Brasileira. Alguns atores da rede, em função de suas duplas e triplas vinculações, trazem desafios futuros para questões relevantes na análise da Rede do Ipea.

Do ponto de vista da análise quantitativa, explorada em 37 anos de existência da reconhecida série periódica no contexto acadêmico nacional, a série temporal, que possui caráter longitudinal, parece explicar questões relacionadas à produção do Ipea, que parecem estar ligadas a outras variáveis, como o número de pesquisadores. Durante o fechamento desta pesquisa foi apresentada a "Proxy" de desempenho para alguns pesquisadores do Ipea, com objetivo de avaliarem a descoberta e concederem entrevista para complementarmos as observações qualitativamente.

Tendo em vista se tratar de uma dissertação ampla, o referencial teórico está apresentado em duas partes e os resultados obtidos foram organizados em sete diferentes capítulos. Espera-se assim facilitar a organização e leitura deste trabalho. 


\section{REFERENCIAL TEÓRICO (Referencial teórico para Análise de Redes, ver p. 97 -102)}

\subsection{Primórdios da Comunicação Científica}

A comunicação científica é a força motora das redes de pesquisa. A transferência de conhecimentos, que ocorre a partir dos diversos canais de comunicação científica, é fundamental para o desenvolvimento da ciência, por essa razão a consideramos tão importante. Estudar a sua constituição, dinâmica e funcionamento torna-se estratégico para países como o Brasil, que almeja avançar da chamada zona periférica da ciência, onde estamos localizados hoje, para a zona Central da ciência.

O termo "comunicação científica", segundo Christovão (1997), foi "cunhado pelo físico e historiador da ciência irlandês John Bernal, na década de 40, e denota o amplo processo de geração e transferência de informação científica". Quase 40 anos depois da definição de Bernal, surge uma das definições mais citadas e difundidas desta expressão. William Garvey (1979) descreve a comunicação científica como "o conjunto de atividades associadas à produção, disseminação e uso da informação, desde o momento em que o cientista concebe uma ideia para pesquisar, até que a informação sobre os resultados da pesquisa seja aceita e passe a constituir uma parte do conhecimento científico".

No mesmo sentido, em um dicionário especializado, Cunha (2008) apresenta o seu significado para o termo que, para o autor, se refere ao "processo específico de produção, consumo e transferência de informação no campo científico". Em outro glossário, encontramos a definição de Lara (2006), que define a comunicação científica como um processo que abrange a construção, a comunicação e o uso do conhecimento científico, com o propósito de promover a sua evolução. Lara (2006) absorve a classificação básica de Meadows (1999), subdividindo a comunicação científica a partir dos seus canais formais e informais, ambos utilizados pelos pesquisadores e cientistas tanto para publicarem os resultados de suas pesquisas, quanto para informar sobre os resultados alcançados por outros pesquisadores.

Como visto com Garvey (1979), o processo de "disseminação da comunicação científica" se inicia desde o momento em que o pesquisador inicia a pesquisa até que os resultados sejam integrados ao conhecimento científico. $\mathrm{O}$ autor acrescenta que o processo de "disseminação da comunicação científica" inclui várias etapas, dentre as quais destaca: os relatórios preliminares; a conclusão dos trabalhos de pesquisa; os relatórios de pesquisa para pequenos grupos de audiência e para audiências restritas; as comunicações em eventos profissionais especializados, tais como congressos e conferências, com seus respectivos anais ou proceedings.

$\mathrm{O}$ autor segue listando encontros e eventos presenciais, a partir de suas características de localização (locai, regionais) e periodicidade (anuais). Abrange ainda os relatórios técnicos; a submissão de manuscritos; a distribuição de pré-prints; a divulgação em listas de aceitação de manuscritos; a publicação em periódicos científicos; a inclusão em índices de resumos e sumários; a aparição em revisões anuais, a citação em outros artigos científicos; a inclusão em boletins e finalmente em tratados especializados (GARVEY, 1972). 
Somam-se a todas as definições para o termo, uma proposta interessante feita por Crane (1972), para quem a "comunicação científica constitui uma forma de difusão", na qual as ideias são transmitidas em uma rede de colaboração, de pessoa para pessoa, "paralelamente a um processo de interação social". O autor traz para a definição o que chamou de processo de interação social. Interessa-nos muito esse aspecto da comunicação científica que abre portas para o estudo de redes de colaboração no contexto da produção científica, um dos objetivos desta pesquisa.

A comunicação científica abrange um conjunto de funções inerentes ao seu principal propósito. Kaplan e Storer (1968), a partir de um estudo de Menzel (1966), descrevem as seguintes funções para a comunicação científica: 1. Disponibilizar aos cientistas as melhores respostas para questões específicas; 2 . Contribuir para que o cientista conheça as novas descobertas em seu campo de atuação; 3. Estimular os cientistas a captarem novos conhecimentos, que vão além de suas áreas de interesse; 4. Divulgar as principais tendências de pesquisa de áreas emergentes, fornecendo aos cientistas uma ideia da relevância de seu trabalho; 5. Provar a confiabilidade dos novos conhecimentos, ante a possibilidade de depoimentos e de verificações; 6. Ampliar o papel e o interesse dos cientistas e, por fim, 7. Fornecer conhecimentos que retroalimentam e aperfeiçoam a produção do pesquisador.

Destacam-se ainda Roosendaal e Geurts (1998), que definem outras funções da comunicação científica, quais sejam: 1. Prover o registro de autoria, assegurando o reconhecimento e a propriedade sobre um determinado avanço ou descoberta científica; 2. Fornecer a certificação, permitindo que sejam assegurados tanto o controle da qualidade, como a validade de determinado conhecimento, por meio do processo rigoroso de avaliação pelos pares; 3 . Manter a atualização da comunidade científica, possibilitando a disseminação e o acesso às pesquisas, permitindo que a comunidade científica se mantenha atualizada em relação às novas descobertas e por fim, contribuir para o armazenamento da informação científica, guardando e preservando os valiosos registros do conhecimento científico por tempo indeterminado.

Costa (2000), afirma que:

\footnotetext{
"Pesquisadores em qualquer área do conhecimento precisam comunicar seus resultados por meio de um sistema de comunicação e no mais breve espaço de tempo possível. Destarte, a dinâmica do processo de comunicação científica como um sistema complexo de interdependência, constitui uma boa arena para o estudo de comunidades" (COSTA, 2000).
}

Nesse contexto, optou-se por compreender a Comunicação Científica, esse importante sistema que coloca indivíduos em contato por meio da produção científica, entender as atividades mais remotas que tiveram e têm impacto na comunicação científica moderna. Embora o sistema de comunicação científica exista desde a antiguidade, vários autores consideram que os primeiros periódicos científicos publicados no séc. XVII foram os precursores do modelo moderno de comunicação científica estabelecido. Esse modelo tem sido, a partir do surgimento dos computadores e da Internet, frequente objeto de estudo, em função das alterações na concepção dos próprios elementos constituintes da comunicação científica, do papel de seus atores nesse novo contexto e das mudanças de prioridades em relação ao conhecimento científico (LARA, 2006). 
Sabe-se que as atividades mais remotas que tiveram impacto na comunicação científica moderna foram as dos gregos, que se valeram da fala e da escrita. Os termos "Academia" e "Simpósio", por exemplo, eram utilizados pelos gregos para definirem respectivamente o "lugar na periferia de Atenas, onde, nos séculos V e VI aC, pessoas se reuniam para debater questões filosóficas" e "festa grega onde debates e bebidas circulavam livremente"; ambos os conceitos utilizados no contexto da pesquisa falada, ou comunicação cientifica oral. Em relação à pesquisa comunicada na forma escrita, os gregos, tendo à frente Aristóteles, que teve seus debates em manuscritos copiados repetidas vezes, circulando pela Europa; influenciaram a cultura árabe e depois a Europa ocidental (MEADOWS, 1999).

Francis Bacon, autor do Novum Organum (Novo Instrumento), nasceu em Londres, em 22 de janeiro de 1561. Naquela época, a Inglaterra já apontava como a mais poderosa nação da era moderna. Com apenas 12 anos, Bacon foi enviado ao Trinity College, em Cambridge. Sabe-se que desde muito cedo se interessou pela filosofia, pela política e pela ciência. O título do Novum Organum, sua obra máxima publicada no ano de 1620, é uma contraposição à obra Organon de Aristóteles. Nela Bacon apresenta e descreve seu método para as ciências, tendo se destacado por sua obra onde a ciência era exaltada como benéfica para o homem. Em suas investigações, ocupou-se especialmente da metodologia científica e do empirismo, sendo muitas vezes chamado de "fundador da ciência moderna".

Meadows (1999) traz para a discussão o argumento de Francis Bacon, de que: o aumento do conhecimento está ligado à sua comunicação. Para Meadows a maneira como o cientista transmite informações depende do veículo empregado, da natureza das informações e do público-alvo. O meio disponível e a natureza da comunicação científica afetam não só a forma como a informação e apresentada, mas também a quantidade de informações em circulação".

King (2004) destaca que o número global de artigos científicos publicados, em diferentes áreas do conhecimento, tem aumentado ao longo dos anos. Além disso, sabe-se que a produção científica das nações está relacionada com as características socioeconômicas dos países.

Derek de Solla Price (1976), relacionou o fato do conhecimento científico não mais perder-se no passado, a mercê de sua própria sorte, graças à comunicação científica. A invenção da imprensa por Johann Gutenberg, no século XV, é um dos acontecimentos que também é apontado como que decisivos na mudança da história da leitura e da circulação de ideias. Até a invenção da imprensa, a humanidade passou várias vezes pela deterioração de suas tradições científicas. Como destaca o autor, o saber científico rompeu essa desastrosa sina do esquecimento a partir da invenção da imprensa e de sua rápida disseminação pela Europa, que, segundo o autor, alterou drasticamente os hábitos de leitura e o esquema acadêmico das nações.

Bem-David (1974, p. 37), diz que a invenção da imprensa trouxe solução para as chamadas deficiências nos mecanismos de transmissão e difusão do conhecimento. Para o autor, o acúmulo rápido de conhecimento, que caracterizou o desenvolvimento da ciência a partir do século XVII, nunca ocorreu antes dessa época. O novo tipo de conhecimento surgiu apenas em alguns países da Europa Ocidental, e se limitou a essa pequena área durante aproximadamente duzentos anos. A partir do século XVII o 
conhecimento científico foi assimilado pelo resto do mundo. Segundo o autor, essa assimilação não ocorreu por meio da incorporação da ciência às culturas e instituições, ao contrário, ocorreu por meio da disseminação dos modelos de atividade científica e papéis científicos da Europa Ocidental para outras partes do mundo.

Meadows (1999) escreve sobre praticamente todos os aspectos da comunicação científica, passando por seus atores, canais e redes. Nesta pesquisa, estuda-se uma importante série periódica brasileira, e busca-se, de certa forma, descrevê-la a partir dos critérios estabelecidos para os canais de comunicação científica. Pode-se tanto levantar características dobre os TDs, como analisar a produção científica e a produtividade do Ipea a partir da série. Além disso, a análise da coautoria forneceu importantes resultados do ponto de vista da Análise de Redes Sociais (ARS). Os estudos dos canais, dos atores e das redes, como pontuado por Meadows (1999), podem ser importantes instrumentos de gestão para instituições que pensam e produzem conhecimento. Este é o caso do Ipea, instituto de pesquisa criado no âmbito da Administração Pública Brasileira (APB), importante ator no contexto da história do pensamento econômico brasileiro.

O autor aborda, há mais de 17 anos, questões como o a diferença entre a quantidade de informação produzida, que pode ser contada a partir do número de trabalhos publicados, e o volume de conhecimento de fato produzido. Este dado nos interessa, pois podemos relacionar futuramente o "volume do conhecimento" e a "quantidade de conhecimento", no caso da produção científica do Ipea.

"Estima-se que a produção média de livros por ano no mundo aumentou de 420, no período de 1436-1535, para 5.750 durante os cem anos seguintes (1536-1636). A maior parte desses livros nada tinham a ver com a comunicação da ciência, mas sabemos que o "livro impresso" teve grande impacto na difusão das informações" (MEADOWS, 1999, p. 3).

O ano de 1543 foi o ano da publicação de duas grandes obras: a "Das revoluções dos corpos celestes", de autoria de Copérnico, que fundou a astronomia moderna; e a "Da estrutura do corpo humano", de Versálio, tida como a primeira obra moderna sobre anatomia humana. Tais obras estavam ligadas a produção científica de autores ligados às universidades, cujos serviços de impressão e edição, como, por exemplo, a "Oxford University Press", foi estabelecida na segunda metade do século XV. Os serviços postais e os primeiros jornais surgiram um pouco depois, no século XVI.

Meadows (1999) destaca que "a introdução da imprensa na Europa, no século XV" possibilitou aos docentes das universidades, como os de Oxford nos tempos de Chaucer, terem acesso aos manuscritos e livros que continham análise e interpretação de novas ideias. Sabe-se, no entanto, que a transição da forma manuscrita para a forma impressa não se deu instantaneamente, de uma hora para outra. Noticiários manuscritos continuaram a ser produzidos durante todo século XVII até o século XVIII.

A comunicação científica pode ser definida como sendo o processo de comunicação e troca de informações e conhecimento entre os membros da comunidade científica mundial. Pode ocorrer por meio de canais formais e informais de comunicação científica, segundo a classificação feita por Meadows (1999, p. 39). Para o autor, os canais informais são formas efêmeras de comunicação, justamente por ficarem à disposição de um público limitado e por pouco tempo. O autor cita conversas e encontros científicos como exemplos. Os e-mails devem ser considerados como parte das comunicações informais, 
por não acontecer "formalmente" no contexto da comunicação científica e ter caráter privado e não público.

Os canais formais se caracterizam por serem uma comunicação de caráter público e duradouro, que fica disponível por longos períodos de tempo, para um público amplo. Podemos citar, por exemplo, periódicos científicos, livros, relatórios e proceedings, que são uma espécie de "coleção de artigos científicos" publicados no contexto de conferências acadêmicas. (Meadows, 1999). Percebe-se que para o autor, a definição do que são os canais formais de comunicação científica tem relação com os meios que dão suporte para o registro do conhecimento, a informação científica registrada ou ainda o conhecimento cientifico explícito. Entre os canais formais, passados cerca de 400 anos, ainda se destacamos periódicos científicos.

Meadows (1999) destaca que, já no início do século XVII, as publicações resultantes de iniciativas como as da importante família de banqueiros, os Fuggers; que forneciam aos seus clientes boletins de notícias comerciais vindas de toda a Europa; foram, certamente, os ancestrais dos jornais modernos, que também serviram de modelo para o surgimento dos periódicos científicos. $\mathrm{Na}$ metade deste mesmo século, surgiram as revistas científicas.

\subsection{O surgimento dos periódicos científicos}

Para Weisman (1972), a origem dos periódicos científicos está relacionada com a necessidade de compartilhamento de conhecimentos entre os cientistas e foi marcada inicialmente pela troca de correspondência entre os cientistas. Uma carta de um cientista era, com frequência, enviada a outros cientistas. Com a invenção e difusão da tipografia, os periódicos especializados começaram a ocupar o espaço das cartas como um meio de intercâmbio de informação.

Para Meadows (1999), o periódico científico surgiu há mais de 350 anos. A partir do século XVII, gradualmente ele foi substituindo e ampliando os canais de comunicação à época, como a correspondência pessoal e os livros científicos. Por razões diversas ocorreu esta substituição, dentre as quais o autor destaca necessidade do debate coletivo para a construção do conhecimento científico e a importância da validação própria da ciência.

Stumpf (1996) fala que o declínio do livro científico, como meio mais importante e completo para a publicação da pesquisa original, foi devido às pressões que começaram a ocorrer dentro da comunidade de pesquisadores, principalmente as relacionadas: 1) às queixas pela prioridade e originalidade das descobertas científicas; 2) à demora na publicação dos livros; ao custo da produção e até mesmo a extensão destes.

A restauração da monarquia na Inglaterra ocorreu em 1660, fato que precedeu à formação da Royal Society, em 1662, que desde cedo se dedicou à comunicação científica. Os fundadores dessa pioneira "Sociedade Real" foram influenciados pelos trabalhos de Francis Bacon; que, ao descrever as atividades de uma instituição de pesquisa, recomendara que concedessem alta prioridade à coleta e análise de informações importantes. 
Dentre as recomendações de Bacon, encontra-se a de que certos membros de uma instituição de pesquisa deveriam viajar o estrangeiro com o objetivo de coletarem dados por meio de conversas e observações diretas; e que tantos outros deveriam permanecer na instituição elaborando resumos da literatura publicada no mundo todo. Sabe-se que outro método adotado consistiu em eleger membros da sociedade vindos de países estrangeiros, para que esses pudessem relatar à Royal Society os progressos ocorridos em diferentes países. O primeiro desses membros estrangeiros foi John Winthrop.

Outra estratégia alinhada às recomendações de Bacon foi desempenhada pelo poliglota, Henry Oldenburg, que, no papel de secretário da nova sociedade, era responsável pelas cartas destinadas a correspondentes no país e no exterior, atuando como um núcleo de coleta e disseminação de novas ideias e pesquisas. Concomitantemente, em Paris, pesquisadores atuavam com o mesmo objetivo, tendo Marin Marsenne e Denis de Sallo como pioneiros no papel de Oldenburg.

\subsection{Os dois primeiros periódicos da história: Journal des Savants e Philosophical Transactions}

Em 5 de janeiro de 1665, sob a responsabilidade de Denis de Sallo, foi publicado na França, o primeiro número do "Journal des Sçavans" (que teve seu título alterado para "Journal des Savants" no começo do século XIX); esta considerada a primeira revista em sentido moderno.

Para se ter uma ideia da velocidade que a comunicação da ciência, entre centros importantes naquela época, apenas seis dias após a publicação do primeiro número do "Journal des Savants", exatamente no dia 11 de janeiro de 1665, Oldenburg leu parte de seu conteúdo em uma reunião da Royal Society. Inspirados, tudo leva a crer pela publicação do primeiro número dessa revista, o Conselho da Royal Society determinou a criação da "Philosophical Transactions" (também conhecida pelo seu título abreviado "Phil. Trans."), sugerindo uma periodicidade mensal, caso houvesse matéria para isso. Não havia um número pré-fixado de artigos, no entanto, já se previa a avaliação pelos pares, que deveria ser feita por membros da Royal Society e a determinação de um fluxo de aprovação, que necessariamente passaria pelo Conselho.

Meadows (1999) diferencia o surgimento dos dois primeiros periódicos da história da seguinte forma:

\footnotetext{
"Embora as revistas francesa e inglesa surgissem no cenário ao mesmo tempo, havia nítidas diferenças de conteúdo e intenções. No prefácio do primeiro fascículo do Journal des Scavans, Denis de Sallo explicava que seu periódico destinava-se a realizar inúmeras coisas diferentes: catalogar e resumir os livros mais importantes publicados na Europa; publicar necrológios de personalidades eminentes; descrever os progressos científicos e técnicos; registrar as principais decisões jurídicas e, em geral, cobrir todos os tópicos de interesse dos homens letrados".O título original completo do periódico da Royal Society - Philosophical Transactions: Giving some Account ofthe present Undertakings, Studies and Labours of the Ingenious in many considerable parts of the World - sugere cobertura igualmente ampla" (Meadows, 1999).
}

A limitação anterior acerca do estudo de certos temas permanecia, uma vez que a Royal Society alegava que somente se interessava por estudos experimentais. As Philosophical Transactions são consideradas o precursor do moderno periódico científico. O Journal 
de Scavans não conseguiu manter o amplo número de temas e passou a se concentrar em temas tidos como não científicos, sendo considerado o precursor do periódico moderno de humanidades.

Os periódicos científicos, que como visto, surgiram na segunda metade do século XVII, traziam a necessidade crescente de comunicação, que deveria ocorrer de modo mais eficiente possível, como o motivo principal de seu surgimento. As implicações da introdução do periódico para a comunicação científica, em particular, significavam uma "formalização" do processo de comunicação científica.

\subsection{A formação das chamadas "sociedades" científicas e a criação da Royal Society}

Os esforços relativos à expansão do conhecimento assumiram um local de destaque no mundo ocidental durante o século XVII. A comunicação dos resultados de pesquisas era apontada como importante instrumento, uma vez que havia uma suposição de que o mundo antigo não havia detido o monopólio da criação de novos conhecimentos.

Solla Price (1976) apontou que, antes deste período, a humanidade passou várias vezes pela "deterioração de suas tradições cientificas". Em muitas sociedades, uma geração contemporânea de cientistas e pesquisadores teve que começar de estágios já ultrapassados pelos seus antecessores, ignorando avanços e descobertas anteriormente feitas, por razão da deficiência no processo da comunicação cientifica. O conhecimento era apontado como cumulativo. Podiam ser acrescentadas novas ideias e comentários ao conhecimento conhecido de modo a criar um nível mais elevado de conhecimento. Esse processo de acumulação de conhecimento era recíproco, envolvia o fornecimento de informações para o recebimento de outras.

As Sociedades científicas são apontadas como um antigo canal ou veículo da comunicação científica. As sociedades realizavam encontros periódicos, onde a difusão "informal" de informações ocorria de diversas formas. As sociedades científicas passaram a estabelecer programas editoriais em complemento às reuniões. Os objetivos eram: 1) tornar público os trabalhos de seus sócios; 2) ampliarem o acesso aos resultados para pessoas de fora da sociedade; e 3) proporcionar um registro adequado do conhecimento para transmissão às gerações futuras.

Sociedades científicas foram fundadas em todas as áreas do conhecimento. Em 1666, na França, foi fundada a Académie Royale des Sciences, aos moldes da Royal Society. Outras academias já haviam sido criadas em Paris à época: A Académie Française (1635); a Académie Royale de Peinture et de Sculpture (1648) e a Académie Royale de Inscriptions et Belles-Lettres (1663).

No século seguinte, o sec. XVIII, observou-se um crescimento acelerado no número de novas sociedades, tendo sido registrado cerca de 70 novas sociedades científicas. Os termos "academias" ou "sociedades" eram empregados a partir de diferentes enfoques organizacionais. O Estado oferecia apoio financeiro ou de outra natureza às academias e estas, por sua vez, estavam mais sujeitas ao controle do governo que as sociedades, que por sua vez contavam com membros diletantes. As academias ofereciam salários aos seus servidores e as sociedades cobravam de seus membros uma taxa relativa à sociedade. A 
frequência média nas reuniões das sociedades era superior a frequência nas academias, ademais, havia diferenças na forma de comunicação científica adotada por ambas.

A Académie Royale des Sciences editava um volume anual no qual colaboravam apenas os seus membros. De outro modo, a Royal Society, por meio das Philosophical Transactions, aceitava publicações de trabalhos de não-sócios e eram editadas várias vezes por ano, tendo condições de oferecer informações mais atualizadas. A periodicidade, uma das principais características dos periódicos científicos, que lhes conferem inclusive parte da terminologia de seu termo linguístico definidor, já era observada pela Philosophical Transactions.

\subsection{Periódicos científicos: definições e conceitos}

A "revista", ou "journal", termo em inglês, no contexto da comunicação científica, pode ser definida como uma coletânea ou conjunto de artigos escritos por autores diversos, distribuídos periodicamente, sob um título único. Outros termos genéricos em inglês, como "transactions" e "proceedings", "atas" em português, são utilizados para publicações resultantes das atividades de um grupo.

Meadows (1999) diz que a forma como os periódicos científicos apresentam as informações evoluiu gradualmente durante os três últimos séculos. $\mathrm{O}$ desenvolvimento do periódico científico influenciou as mudanças de significado ligadas a palavra "journal". Originalmente em inglês, o significado para esta palavra era como um jornal, ou "newspaper".

A partir do século XVII, o termo passou a ser aplicado à publicação periódica que reunisse um conjunto de artigos. Em época aproximada, o termo "magazine" também passou a ser empregado para uma publicação que continha diversos artigos. Nos dois séculos seguintes, o termo "journal" passou a significar uma publicação científica, que continha ideias originais. Ao passo que o termo "magazine" foi sendo utilizado para publicações populares, como as que são vendidas em bancas de jornais.

O termo "periodical" entrou em uso na metade do século XVIII e seu uso é muito similar ao uso do termo "journal". Se refere a publicações com periodicidade definida e artigos diversos de autoria também diversificada. Por fim, a palavra "serial", que pode ser traduzida como seriado ou publicação seriada, surgiu no século XIX para designar quaisquer publicações editadas em partes sucessivas e conexas (MEADOWS, 1999, p. 08).

Outras denominações para o termo "periódico científico" foram elencadas por Stumpf. Tal diversidade é apontada por Castedo (2009) como sendo uma das razões pela qual enfrentamos dificuldade ao propor uma definição adequada para o termo. Stumpf (1998) destaca o uso indistinto e frequente, nos círculos acadêmicos, dos seguintes sinônimos para o termo "periódico científico": 1) revistas científicas; 2) publicações periódicas; 3 ) publicações seriadas". 
A definição de Souza (1992), para os periódicos científicos é:

\begin{abstract}
"Publicações editadas em fascículos, com encadeamento numérico e cronológico, aparecendo a intervalos regulares ou irregulares, por um tempo indeterminado, trazendo a colaboração de vários autores, sob a direção de uma ou mais pessoas, mas geralmente de uma entidade responsável, tratando de assuntos diversos, no entanto, dentro dos limites de um esquema mais ou menos definido" (SOUZA, 1992).
\end{abstract}

Organizações internacionais, tais como a ISO e a ISSN, incluem os periódicos científicos no âmbito das publicações seriadas ou serials. O Código Anglo-Americano de Catalogação os definem como recursos contínuos, ou seja, recursos bibliográficos com periodicidade definida e fascículos sucessivos.

Os "periódicos científicos eletrônicos" são muito recentes. Se considerarmos a data em que surgiram, apontaremos a década de 1970. Se considerarmos a publicação propriamente dita, somente em 1990, 20 anos depois do seu surgimento, foi publicado o primeiro periódico científico em formato eletrônico, devidamente revisado por pares, sob o título de Postmodern Culture. Passados quase 50 anos do seu surgimento, os periódicos científicos eletrônicos respondem quase que totalmente pela totalidade dos periódicos científicos atuais.

Sondak e Schwarz (1973) denominaram essas publicações como "paperless" (sem papel), os autores buscavam uma definição que expressasse melhor a dimensão desse novo formato. Lancaster (1995), também identificou os benefícios dos periódicos científicos eletrônicos e denominou-os a partir de uma de suas principais características, a acessibilidade, propondo um novo conceito denominado "online". Antes de Lancaster, Roistacher (1978) propôs o termo "virtual journal".

Para Sens (2003) o periódico eletrônico realmente não revolucionou a publicação científica, mas acentuou tensões existentes relacionadas à flutuação de preços, à durabilidade, à duplicação de informação, à inovação e obsolescência relacionadas com a vida efêmera dos periódicos. Schirmbacher (2006) abordou o periódico eletrônico, considerando que é importante não somente criar uma reprodução eletrônica da publicação tradicional, mas também mudar o conjunto de processos relacionados, aproveitando todas as vantagens da comunicação eletrônica, para deixarmos para trás práticas editoriais ultrapassadas.

Como foi possível observar, o periódico científico, considerando o seu destacado papel, traz consigo as funções próprias da Comunicação Científica. Diversos autores abordam as diversas funções do periódico científico, que claramente não se limitam à divulgação dos resultados de estudos e pesquisa.

Serviram como base para o estudo "do objeto desta pesquisa", do ponto de vista da forma e da qualidade da pesquisa, autores como Meadows (1999), Aguiar (1991), Albornoz (1994), Spinak (1996 e 1998), Abadal (2006), Guédon (2011) e Velho (1996), dentre outros autores, todos eles discutem as características dos periódicos científicos e foram considerados para a construção do quadro de análise formal, um dos resultados da pesquisa. 


\subsection{Periódicos científicos e os indicadores de qualidade da ciência}

Abadal (2006) propõe uma organização das características e indicadores de qualidade a partir de seus aspectos formais, de difusão e impacto e de adequação ao formato digital que foram muito úteis para a pesquisa. Ademais, a atual forma sob as quais as informações científicas são apresentadas nos periódicos de hoje é resultado das "transformações tecnológicas e das exigências cambiantes da comunidade cientifica". Meadows (1999) destaca que ao examinar um fascículo e os seus respectivos artigos científicos, certamente encontraremos o mesmo "padrão básico" ou forma.

A informação cientifica se diferencia dos demais tipos de informação por sua natureza e pelo seu particular sistema de difusão e comunicação. Aguiar (1991) apresenta as funções da informação científica: i) Divulgar o conhecimento novo obtido a partir de uma pesquisa científica, assegurando assim a prioridade intelectual; ii) Constituir insumo para a atividade de pesquisa científica da mesma forma que representa o produto; iii) A informação científica, contendo a metodologia seguida na execução da pesquisa, serve como instrumento para possibilitar a própria validação do novo conhecimento.

Dessa forma, pode-se resumir informação científica como sendo aquela que envolve o registro de resultados de pesquisas, registrados em um veículo formal, que além de assegurar a autoria, deve possuir uma metodologia clara e que sirva de insumo para geração de novos conhecimentos. Campelo e Campos (1993) listam como funções do periódico o registro público, o reconhecimento dos autores e a difusão das informações, este último papel é exaustivamente enfatizado por diversos autores como Mayor (1996) e Valério (2005).

O registro público ou a publicização, na opinião de Hayashi et al. (2007) está ligado com a questão da avaliação, pois permite "realizar o processo de controle de qualidade do artigo por meio da aplicação do sistema de revisão pelos pares, peer review ou refereeing, em inglês, que objetiva a verificação da veracidade, originalidade, importância e qualidade dos artigos submetidos à publicação a partir da troca de informações entre editores e avaliadores.

Considerando a avaliação de periódicos, há vários critérios propostos na literatura, alguns relativos à forma, outros à qualidade. Braga e Oberhofer (1982) falam em sete critérios: normalização, duração, periodicidade, indexação, difusão, colaboração e divisão de conteúdo e autoridade. Stumpf (2003) discute a relevância de critérios referentes à qualidade do conteúdo, à reputação da instituição que o publica e dos autores, além de medidas de citação como fator de impacto.

Correia (2001) destaca a insatisfação dos autores e outros atores envolvidos quanto ao papel dos periódicos científicos como um veículo privilegiado para a comunicação científica. Entre essas insatisfações, podemos listar: 1) o processo demorado de submissão, avaliação e publicação, o que prejudica a rápida difusão de conhecimentos. Tal insatisfação pode ainda a se agravar frente a outras possíveis plataformas de difusão que flexibilizam algumas etapas e questionam o processo de publicação científica como um todo; 2) também ligado à ideia de difusão, a questão de direitos autorais, que muitas vezes dificultam à rápida divulgação de resultados. Esse ponto tem efeitos inclusive sobre as avaliações de pesquisadores, baseadas em fator de impacto, já que um acesso mais aberto às publicações tende a aumentar o alcance das pesquisas; 3 ) o rigor do processo de 
peer-review, com favorecimento de instituições de prestígio e atrasos desnecessários; e 4) o seu próprio funcionamento em uma época em que versões preliminares são divulgadas antecipadamente, tornando difícil uma blind review efetiva.

Ainda relacionado a essa questão de direitos autorais, há também a questão do custo da pesquisa para a sociedade, explicitado por um desencontro entre o valor das assinaturas proprietárias dos periódicos e os orçamentos das universidades e instituições de pesquisa que, muitas vezes, foram as que financiaram ou pagaram por aquelas pesquisas e são obrigadas a recomprar os seus resultados por meio dessas assinaturas. De acordo com Dawrs (2012), os valores das assinaturas anuais de publicações científicas cresceram a uma taxa superior às taxas de inflação, levando a um aumento de US\$1.496.775 para US\$4.660.349 entre 1986 e 2001 na despesa média anual das publicações seriadas das bibliotecas da Association of Research Libraries. Kyrillidou, Morris e Roebuck (2011) apontam um aumento de $381 \%$ desde 1986 , ou seja, em média de 7,4\% ao ano, chegando a US\$7.193.291 em 2009.

A informação científica, esclarece Velho (2014), é registrada e publicada em diferentes canais de comunicação científica, dentre estes, artigos científicos, livros, teses e dissertações. Para a autora, as avaliações quantitativas das publicações científicas apontam caminhos para a distribuição de recursos destinados ao desenvolvimento científico e tecnológico.

Dessa forma, sabemos que os indicadores bibliométricos são uma forma de avaliar as dinâmicas das atividades científicas e tecnológicas. Spinak (1998) considera que qualquer indicador para a avaliação do chamado "sistema de comunicação científica" deve ter como uma de suas referências as metas estabelecidas para o país pela política nacional científica, "não necessariamente condizente com a ciência internacional". Nesse sentido, Velho complementa:

\footnotetext{
"A avaliação do trabalho científico através de indicadores quantitativos é um tema que vem ganhando cada vez mais espaço em estudos acadêmicos e não é por acaso. Essa avaliação, ou melhor, os diversos tipos de avaliações de trabalhos científicos, são um dos critérios utilizados por governos e órgãos multinacionais, como a Unesco ou a Organização Mundial da Saúde, para decidir como direcionar seus recursos destinados à pesquisa e ao desenvolvimento. Trata-se de um instrumento com o qual está-se decidindo quem vai ganhar dinheiro para pesquisar ou quem será tido como improdutivo e que, por isso, vai ter que se contentar com menos ou nenhum recurso. Para os mais diversos donos e gestores de recursos, faz cada vez mais sentido utilizar avaliações da produção científica, pois a disponibilidade de recursos para ciência é limitada e compete com os demais setores de investimento público" (VELHO, 2014).
}

No mesmo sentido, Albornoz (1994) assinala que, com muita frequência, "os indicadores escolhidos estão inspirados em sistemas estatísticos de países desenvolvidos e apresentam dificuldades de aplicação no contexto local". Por essa razão, Velho (2014) sugere reunir todas as estatísticas geradas nas tentativas de planificar e administrar a ciência, em seguida fazer os ajustes necessários e depois procurar teorias subjacentes.

Guédon (2011) denuncia o controle dos índices internacionais, de valoração de periódicos científicos, por parte das grandes corporações responsáveis pela editoração científica. Para o autor, o propósito seria manter o controle destas ferramentas, validadas e reconhecidas pela comunidade científica, que mantém a divisão da ciência central em relação à ciência periférica, onde se encontra toda produção dos países da América Latina. 
Esta situação se mostra prejudicial para a produção científica regional, já que sistematicamente sua visibilidade por aqueles canais ficaria prejudicada.

Velho (2014) destaca certos "vícios de origem" dos índices usados para avaliações quantitativas dos trabalhos científicos. O resultado de tais avaliações "apontam para este ou aquele cientista, esta ou aquela área do conhecimento, este ou aquele país, como mais férteis ou mais produtivos". A autora toma como exemplo o índice que serve de base para quase todas as avaliações da produção científica no mundo, o conhecido Science Citation Index (SCI), que é compilado desde 1963 pela empresa americana Institute for Scientific Information (ISI). O SCI elabora suas avaliações a partir das citações a autores em artigos publicados exclusivamente em revistas indexadas em suas bases de dados. Para se ter uma ideia diz a autora, em um total de 3.762 revistas, apenas 3 (três) são brasileiras. Em uma lista "paralela", intitulada "SCI Expanded" há apenas 15 (quinze) revistas brasileiras para 5.891 indexadas.

A partir destas citações, uma lista dos trabalhos mais citados aparece, gerando conceitos e métodos para medir a produção científica. Os avanços tecnológicos proporcionam recursos para a manipulação de dados, onde informações sobre a produção científica podem ser facilmente encontradas, como por exemplo, quantas vezes tal cientista foi citado ou qual disciplina tem maior número de citações.

O SCI lista a produção científica por: 1) publicações, destacando os títulos dos artigos e periódicos; 2) citações e autores e coautores, destacando cientistas e pesquisadores, projetos, departamentos, institutos e países. Os dados são agregados de diferentes formas, como por escolas de pensamento, por grupos teóricos, por especialidades, "redes", aglomerados, etc. No final tem-se a representação estrutural e gráfica domínios e níveis da atividade de pesquisa na ciência.

Sobre citações como medida de desempenho, diz Velho (2014):

\footnotetext{
“Aparentemente simples e direto, e por isso adotado sem cerimônias por quase todos os que se dispõem a avaliar produção científica, o SCI enquanto base de dados, de fato, apresenta uma série de problemas, tanto do ponto de vista conceitual como metodológico" (Velho, 2014).
}

Os estudos de citações como medidas do desempenho científico estão baseados em um ponto crucial, na "qualidade", ou seja, critérios científicos que devem ser seguidos para que uma publicação científica gere impacto, isto é, o número de citações que um artigo recebe num dado período.

Neste contexto, Velho (2014) relaciona uma série de questões controversas relacionadas à premissa de que uma publicação científica deve ter certa qualidade básica para então gerar impacto. Para a autora, tal premissa é bastante discutível por uma série de questões, dentre os quais destaca: 1) Tendência de autocitação observada entre cientistas que, frequentemente, citam seus próprios trabalhos; 2) Tendência de citação de trabalhos de amigos; 3) Imperfeição do próprio Sistema de Comunicação Científica Internacional, tornando questionável a mensuração a partir das citações, uma vez que o próprio "acesso" a produção científica é variável; 4) Barreira linguística que separa os cientistas de determinadas publicações. Há uma barreira linguística que separa os cientistas de determinadas publicações indexadas no SCI em uma "zona central da ciência", de onde são colhidas as citações; 5) Tendência de citação da pesquisa fundamental em detrimento da experimental, produzindo um falso desprestígio para a segunda, que não é menos 
importante que a primeira; 6) Diversidade de práticas relacionadas a publicação de resultados de pesquisa em periódicos, conforme a área de conhecimento; 7) Citação leviana ou superficial, quando trabalhos são citados sem que tenham sido sequer lidos ou analisados cuidadosamente; 8) Citação por tabela, ou de segunda mão, quando são feitas a partir de um artigo secundário, sem que o artigo primário leve o crédito, não sendo este lido ou citado; 9) Citações decorativas, encaixadas nos trabalhos científicos após a sua elaboração, como forma de adequá-lo ao ritual "acadêmico".

Atualmente, muitos autores questionam métricas relacionadas à qualidade dos periódicos de um país ou seu desempenho científico, quando medidos a partir de estudos de citações, ou seja, a partir do número de citações que um artigo recebe em um determinado período. Recentemente, um membro de destaque na Comunidade científica mundial, ganhador do Prêmio Nobel de Medicina e Fisiologia de 2013, Randy Schekman (2013) denunciou as revistas científicas pela mercantilização da ciência. Em artigo publicado no jornal inglês The Guardian, em dezembro de 2013, ele afirma que os incentivos ofertados pelas principais revistas distorcem a ciência.

Schekman, mostrando-se atento à mercantilização da pesquisa, diz que:

\footnotetext{
“As decisões editoriais das grandes revistas científicas são guiadas por interesses comerciais, não apenas científicos, e que a cultura de supervalorização dessas publicações como estandartes de qualidade é prejudicial à ciência como um todo" (SCHEKMAN, 2013).
}

Colocar as grandes revistas científicas como "prejudiciais" a Ciência, principalmente se considerarmos que ele é um pesquisador ganhador de um Prêmio Nobel, membro da Sociedade Americana de Ciências, e sendo os Estados Unidos hoje a maior potência mundial em termos de produção cientifica e produção de patentes; foi um ato de bastante coragem e ousadia. Não diz respeito apenas a mercantilização da ciência, mas, sobretudo sobre uma "censura mundial" ou "seleção não-qualitativa" que encobre os resultados da ciência e direcionam os olhos de quem consome a ciência nos dias atuais.

Em dezembro de 2013, o ANDES-SN, Sindicato Nacional dos Docentes das Instituições de Ensino Superior, fez denúncia semelhante em reportagem da Revista Dossiê Nacional Precarização II, intitulada: Desvio ideológico na concepção do mérito acadêmico, provocado por esse sistema de produção igualmente conhecido como "mcdonaldização" da ciência.

Schekman (2013) classificou esses "periódicos supervalorizados", no contexto da Comunicação Científica, de "revistas de luxo" e levantou argumentos para denunciá-los. O principal argumento apontado pelo professor é que esses periódicos de luxo publicam muitos trabalhos importantes, notadamente, mas não só trabalhos importantes; e destacou o fato de que nem são elas as únicas a publicarem pesquisas relevantes e importantes. $\mathrm{O}$ professor argumenta que inúmeras vezes os critérios de escolha do que é publicado ou rejeitado nessas "revistas de luxo" baseiam-se numa "avaliação de impacto" que não reflete necessariamente ou unicamente a qualidade e/ou a importância de um trabalho científico, mas refletem também a própria repercussão na mídia e o número de citações que ele poderá trazer para a revista.

O que se pode concluir das palavras de Schekman (2013), é que as pesquisas científicas não são avaliadas por esses "periódicos de luxo" apenas pelo seu impacto científico, mas também pelo seu potencial impacto midiático e econômico. São revistas comerciais, diz 
o pesquisador, que cobram muito caro pelo seu conteúdo e precisam vender assinaturas para sobreviver financeiramente.

Como visto, estes "periódicos de luxo" além de venderem assinaturas, como destacado pelo Nobel, passam a adotar o Open Acess, ou Acesso Aberto, como modelo de negócios, onde não existe a intenção primeira de publicização da ciência, sem fins lucrativos, como podemos observar nas Revistas Científicas da "Via Dourada de Harnad (2001), mas apenas objetivam a extensão de seus ganhos econômicos. Ao contrário do praticado atualmente por estas revistas de luxo, acredita-se que este modelo de Acesso Aberto, que é o modelo adotado pelo Ipea para a publicação da série "Textos para Discussão (TD)", seja extremamente adequado para a divulgação de resultados de estudos e pesquisas financiadas com recursos públicos.

Sobre o Fator de Impacto (FI), Schekman (2013) diz que é preciso considerar que:

\footnotetext{
“O Fator de Impacto (FI) é uma nota média, baseada no total de citações recebidas por todos os trabalhos publicados numa revista ao longo de um determinado período, e que mesmo o fato de um trabalho ser muitas vezes citado não significa, necessariamente, que ele seja muito importante para a ciência" (Schekman, 2013).
}

O pesquisador enumera outras razões que podem levar um artigo a ser demasiadamente citado. Um trabalho pode ser muito citado porque é de fato boa ciência, ou porque é chamativo ou provocativo ou ainda incorreto. Relativizando a importância do FI como um indicador de qualidade e relevância para a ciência, e, denunciando a mercantilização da ciência, sobretudo sobre uma censura mundial ou seleção não-qualitativa, que encobre os resultados da ciência e direciona os olhos de quem consome a ciência nos dias atuais; o pesquisador nos apresenta o cenário que denomina de "prostituição da ciência".

Para ele, os editores das "revistas de luxo", por conhecerem as características de um trabalho chamativo e provocativo, acabam por aceitarem trabalhos que vão repercutir porque tratam de assuntos que são "sexy" ou propõem conclusões desafiadoras. Tais decisões, relativas à comunicação científica, acabam direcionando os investimentos em determinadas pesquisas em detrimento de outras. Enquanto encorajam um certo "modismo científico", desencorajam pesquisadores de qualidade, em relação a continuidade de pesquisas da boa ciência, que frequentemente veem seus trabalhos rejeitados por essas "revistas de luxo". Resultados negativos, por exemplo, são muitas vezes rejeitados. Segundo Schekman (2013) as decisões dos editores dessas "revistas de luxo" influenciam a ciência que os cientistas produzem; construindo o que denominou de bolhas de "pesquisa fashion", nas quais os pesquisadores podem fazer propostas ousadas que essas revistas desejam, e desencorajando a realização de outras pesquisas importantes, como a replicação de resultados.

Como alternativa a esse modelo, Schekman defende a publicação em revistas de acesso aberto na internet, os chamados open access journals, sem fins lucrativos. Como falamos, o modelo adotado pelo Ipea para a publicação da série "Textos para Discussão (TD)" é open access journals, extremamente adequado para a divulgação de resultados de estudos e pesquisas financiadas com recursos públicos. Enquanto muitos institutos de pesquisa no mundo todo correm para remodelar seus modelos de negócios, o Ipea tem um periódico científico de relativa idade e que responde exatamente à orientação do Conselho de 
Competitividade da União Europeia, anunciada em 27 de maio de 2016. Tal orientação diz que todos os artigos científicos produzidos por instituições públicas europeias e custeados com recursos públicos, deverão adotar o modelo Open Access (OA) até 2020, modelo no qual não há cobrança pelo acesso aos conteúdos de periódicos científicos.

Velho (2014) lembra que existem vícios de origem nas avaliações da ciência, por meio de índices como o SCI. As avaliações estão baseadas na afirmação subjetiva de que o objetivo da ciência é unicamente, ou principalmente, a produção de novos conhecimentos científicos, como os que são divulgados em periódicos científicos.

Acredita-se, assim como a autora, que outros importantes objetivos da pesquisa científica devem ser destacados, pois contribuem para a análise dos canais de comunicação científica e são de fato muito importantes para o desenvolvimento do país, um dos objetivos para o investimento em ciência e tecnologia. Acredita-se ainda que tais indicadores colocam os periódicos em pedestais e contribuem para que sejam ignorados outros objetivos da pesquisa científica, como a de trazer contribuições para a solução de problemas de um país, papel claramente desempenhado pela série "Textos para Discussão" do Ipea.

A construção dos critérios que integram nosso quadro de avaliação da série TD, do ponto de vista formal, que se apresenta como parte dos resultados desta pesquisa, também levou em consideração os outros objetivos citados por Velho (2014), a saber:

\footnotetext{
“A contribuição para solução de problemas nacionais, regionais, locais; a contribuição para o desenvolvimento tecnológico; a formação e treinamento de novos pesquisadores e de pessoal qualificado para as profissões; o aumento do prestígio nacional e internacional de um país (o que, nas sociedades modernas, tem uma conotação de poder); garantia da autonomia de um país num determinado setor e a influência sobre a visão de mundo da sociedade em geral. Todos esses aspectos não são considerados pelos indicadores quantitativos de "output", tais como os que utilizam as citações em periódicos" (Velho, 2014).
}

Outra questão que fundamenta a utilização de índices como o SCI é de que o produto da ciência e sua qualidade refletem-se integralmente nos instrumentos escritos formais de comunicação científica, particularmente nos periódicos científicos. Tem relação com o reconhecimento dos pesquisadores por seus próprios pares, um tipo de recompensa pelas contribuições originais que fazem ao avanço do conhecimento científico, por meio de seus artigos publicados (VELHO, 2001).

Pode-se diferenciar o conhecimento explícito, que é aquele encontrado nos artigos científicos, do conhecimento tácito, aquele que ainda não foi explicitado e está contido na cabeça do pesquisador (NONAKA e TAKEUCHI, 1995). Nesse sentido, vários autores consideram que a publicação formal é apenas uma das formas de comunicação da ciência, e, portanto, ponderam sobre a derivação das medidas quantitativas a partir unicamente do conhecimento científico explícito.

Este é certamente um dos diferenciais dos países desenvolvidos, que frequentemente se destacam na ciência. Certamente conhecem muito bem as diversas formas de organização e repasse do conhecimento tácito entre os seus pesquisadores e pesquisadores de outros países, para aplicação na pesquisa. São líderes na organização de bases de dados de melhores práticas na pesquisa e lições aprendidas com erros e acertos nesse contexto. 
Alguns conhecimentos tácitos foram descritos por Velho (2001), que destacou as técnicas de laboratório e o treinamento em processos de pesquisas. Para a autora, ignorar as diferentes formas e meios de comunicação informal da ciência, como fazem os indicadores quantitativos convencionais, é muito mais do que simplesmente escolher uma técnica analítica; significa a consagração de um relato demasiadamente racional dos processos científicos, que sistematicamente e insistentemente obscurece suas características fundamentais.

Nesse mesmo sentido, sobre os métodos quantitativos de avaliação da ciência, diz Edge (1979):

"oferecendo uma visão geral objetiva da ciência, como ela é, tais métodos implicam um enfoque impropriamente positivista e realista" (EDGE, 1979).

Outra questão levantada, que diz respeito à quantificação da ciência, tem relação com o "volume" das comunicações científicas e a "importância de certas descobertas". Importa considerar que, as descobertas que colaboram para a quebra de paradigmas têm um peso muito maior para a evolução dos conhecimentos científicos, do que outras contribuições pontuais de menor impacto sobre as teorias estabelecidas. O volume da informação científica, explorada por Meadows (1999), também nos faz ponderar sobre os "indicadores quantitativos da ciência", pois colocam em xeque uma contagem simplista, que considera apenas os números quantitativos da produção da ciência e não o volume, ou seja, aspecto diretamente relacionado com o real "aumento comunicação científica", ou não.

Nesse sentido pondera Velho (2014), que diz:

\footnotetext{
"Mesmo ignorando todas essas objeções, para transformar uma contagem de publicações em uma medida do conhecimento gerado, tem que se admitir que todo artigo contém a mesma contribuição ao conhecimento, apesar dessa premissa ser muito pouco plausível” (Velho, 2014).
}

Outra limitação dos indicadores científicos de "output", apontada por Velho (2014), é que eles não levam em consideração as diferenças significativas dos sistemas de comunicação e do comportamento dos cientistas, se considerarmos ainda as diferentes áreas do conhecimento; as diferentes realidades de cada país e a naturezas diversa das pesquisas, no que diz respeito a serem básicas e aplicadas.

Os responsáveis pela publicação do SCI, em 1985, abriram as portas Institute for Scientific Information (ISI), na Filadélfia, para abrigar uma reunião financiada pela Fundação Rockfeller e pela National Science Foundation (NSF/EUA), que objetivou especificamente discutir a seguinte questão: "a ciência feita nos países de terceiro mundo está adequadamente representada nos indicadores bibliométricos internacionais de produtividade científica?". Sabemos que o relatório final dessa reunião menciona que os participantes estimaram ou subestimaram que apenas cerca da metade da produção desses países, que atinge os padrões internacionais de excelência, está incluída no SCI", como cita Moravcsik (1987). De fato, não existem evidências que justifiquem essa conclusão. Ela é baseada em dois pressupostos, que podem estar equivocados.

O primeiro pressuposto tem relação com a afirmação de que a cobertura desigual e incompleta da produção científica dos países do Terceiro Mundo feita pelo SCI afeta todos os países periféricos e todas as áreas do conhecimento da mesma maneira. Frame 
(1977) afirma que a produção científica brasileira é mais subestimada que a dos outros países latino-americanos, por estar escrita em língua portuguesa.

Chatelin e Arvanitis (1988), afirmam que a contribuição científica de países periféricos, ou do terceiro mundo, varia em função das especialidades da pesquisa. Relatam os autores que a produção é muito maior em determinadas áreas de pesquisa, exemplificando que cerca de metade de toda a produção científica em solos tropicais tem origem no terceiro Mundo. No mesmo sentido, Rabkin et al. (1979) descobriram que a produção científica das ex-colônias britânicas na África, por publicarem em inglês, tem mais visibilidade internacional do que a produção científica de outros países africanos.

O segundo pressuposto tem relação com a afirmação de que a literatura científica produzida pelos países periféricos ou do terceiro mundo, não são indexadas pelo SCI por não atenderem aos padrões internacionais de "excelência". Tal pressuposto rebaixa a produção científica produzida localmente por esses países em suas próprias línguas nativas que não são publicadas por pelos "periódicos conhecidos" e as classifica como sendo de baixa qualidade ou sem interesse para a ciência internacional. Cria-se um modelo que faz uma correspondência direta entre a visibilidade internacional da pesquisa, a qualidade da pesquisa e relevância de pesquisa.

A cerca dessa última questão, sabemos que as decisões de cientistas de países periféricos em relação a escolha do periódico para publicar resultados de estudos e pesquisas científicos é influenciada por diversos fatores, que podem não ter relação direta com a crença na "qualidade da pesquisa" inerente aos canais de comunicação formais da ciência internacional. Muitos estudos exploram e tentam identificar explicações para os diferentes comportamentos encontrados. A quem tiver interesse no aprofundamento dessa questão, sugere-se a consulta aos estudos de Velho (1985) sobre a comunidade científica da área agrícola no Brasil; ou o estudo de Eisemon e Davis (1988), que pesquisaram as áreas de física, biologia, bioquímica, computação e engenharia elétrica em quatro países asiáticos, Coréia do Sul, Formosa, Singapura e Malásia.

Lembra-se novamente que nesse contexto, como relatam diversos autores, dentre eles Meadows (1999) e Velho (1985), há certo consenso no sentido de que o número de publicações não reflete necessariamente a qualidade em ciência. Por essa razão é que se utiliza a contagem de citações recebidas por um determinado trabalho como medida de sua qualidade.

Por outro lado, essa equivalência de número de citações com a qualidade de um artigo é provavelmente o aspecto mais controverso e debatido em toda a literatura sobre indicadores científicos. Vários autores que estudaram o tema escreveram sobre o delicado uso dos dados de citação. Kaplan (1965) disse que é muito fácil fazer inferências não justificadas a partir de análise de citações. Mulkay (1969), afirma que o uso dos padrões de citações [...] claramente envolve uma teoria de citação que está longe de ser satisfatoriamente elaborada.

Outros autores ratificam que a análise de citações requer fundamentos epistemológicos mais seguros. Apesar disso, dados de citação têm se tornado cada vez mais usados. Quase que a totalidade dos estudos empíricos que tentaram estabelecer as relações entre citações e reconhecimento foram conduzidos nos EUA, na área de física e no contexto acadêmico. 
Dessa forma, torna a extensão dos indicadores para as outras áreas, países e contextos, passível de questionamento (VELHO, 2014).

A falta de referencial para comparação das medidas obtidas é outra questão que faz com que se pondere sobre o uso demasiado e exclusivo de indicadores de "output". Morison (1982) aponta que ninguém tem qualquer ideia real sobre qual é a proporção da população científica que está pesquisando o que e quantos são os artigos que deveriam ser publicados proporcionalmente a cada ano.

Por todas essas questões expostas, é muito importante que as avaliações da produção científica levem em consideração que os índices podem abrigar, como dito, vícios de origem, principalmente por não estarem correlacionados com diferentes objetivos da pesquisa.

É necessário ter claro que os objetivos da pesquisa científica, ou o peso a ser dado a cada dimensão desses objetivos, variam conforme o país, o momento histórico e as instituições envolvidas. Esse é um dos grandes problemas da avaliação da pesquisa, pois os pesquisadores e cientistas, os políticos e planejadores, os financiadores públicos ou privados e a própria sociedade têm expectativas diferentes em relação aos objetivos da pesquisa e da ciência, e consequentemente em relação aos produtos das pesquisas, assim como com relação aos padrões de excelência pelos quais elas deveriam ser avaliadas.

Verifica-se que canais alternativos têm sido desenvolvidos para superar alguns desses obstáculos. Publicações científicas eletrônicas têm crescido consideravelmente, buscando a disseminação rápida de resultados. Lagoze e Van de Sompel (2001) apontaram que as disciplinas acadêmicas, especialmente as chamadas de "ciências duras" como, por exemplo, Física e a Ciência da Computação, estão produzindo resultados de pesquisa em um ritmo cada vez maior. Isso significa que talvez o sistema atual de publicação não seja mais adequado para dar vazão a esse ritmo de produção.

Crescendo e ocupando os espaços deixados pelos periódicos estão os e-prints, que têm tido um papel importante na difusão de resultados científicos. E-print é uma versão digital de um documento de pesquisa científica, normalmente um artigo, um livro, ou uma tese, que são revisados pelos pares, antes ou depois da publicação. Antes da revisão pelos pares e publicação, são chamados de preprints, depois da aprovação e arbitragem, são chamados de postprints. Incluem pré-impressões e pós-impressões, bem como rascunhos significantes e intermediários e quaisquer atualizações posteriores à publicação. Nesse modelo, os pesquisadores são encorajados a auto arquivarem os seus trabalhos em repositórios institucionais, fazendo com que os resultados das pesquisas circulem antes mesmo da publicação formal, agilizando assim o processo de comunicação científica. De acordo com Lagoze e Van de Sompel (2001), os e-prints são um exemplo de um modelo mais justo e eficiente para a disseminação dos resultados de pesquisa. Os e-print são, assim, um modelo alternativo de comunicação para algumas áreas da pesquisa (VAN DE SOMPEL e LAGOZE, 2000).

Os e-prints servem o que Harnad (1995) chama de "esoteric scholarly publication" ou publicação acadêmica esotérica. O termo "esotérico" foi utilizado pelo autor como sinônimo de não-comercial, impulsionando a máxima distribuição dos resultados de sua pesquisa e consequentemente maior visibilidade. 
Uma iniciativa antiga e bem-sucedidas quanto ao desenvolvimento e manutenção de um sistema para o armazenamento e disseminação de arquivos e-prints é o arXiv. O arXiv é mantido pelo Laboratório Nacional de Los Alamos, no Novo México, e teve seu desenvolvimento iniciado em 1991, por Paul Ginsparg. Eventualmente, ele se transformou em um repositório global de artigos não-revisados por pares em Física, Matemática e Ciência da Computação. Parte de sua estratégia de comunicação científica é a publicação de resultados de pesquisas em periódicos científicos renomados.

Em conformidade com as diretrizes do arXiv, as versões iniciais das pesquisas não ficam apenas depositadas no repositório, são posteriormente publicadas nessas revistas científicas. Van de Sompel e Lagoze (2000) citaram ainda outros esforços existentes no mundo para a criação de arquivos de e-prints: 1) o CogPrints $<$ http://cogprints.soton.ac.uk/ $>$, organizado pela Universidade de Southampton, do Reino Unido. Criado de acordo com o modelo do arXiv, reúne produções das áreas da Psicologia, Linguística, Neurociências, Ciência da Computação, Filosofia e Biologia; 2) o NCSTRL<http://www.ncstrl.org/>, ou Networked Computer Science TechnicalReference Library, que é uma coleção internacional sobre relatórios de pesquisa em Ciência da Computação. O sistema foi criado formando uma rede, com um modelo descentralizado, no qual os documentos são armazenados em repositórios distribuídos e disponibilizados por serviços também distribuídos, via protocolos de comunicação; 3) o NDLTD, ou Networked Digital Library ofThesesandDissertations, que é uma biblioteca digital de teses e dissertações das instituições membros da rede. Em Economia, destaca-se a RePec, ResearchPapers in Economics, que opera em um modelo distribuído, fornecendo aos autores o envio dos trabalhos por meio do uso de protocolos. Os Textos para Discussão (TD) do Ipea são referenciados e distribuídos pela RePec.

\subsection{Questões econômicas e o movimento "Open Access"}

Patentes e direitos autorais são supostamente utilizados para encorajar o desenvolvimento e a criação de novos do conhecimento. Nas palavras grafadas na constituição americana, "the progress of science and useful arts". Mas será que estão realmente cumprindo esse papel? Será que de fato as proteções temporárias relacionadas ao conhecimento estão mesmo encorajando o desenvolvimento do conhecimento mais que desencorajando? Será que ao permitir a criação de "monopólios do conhecimento" o Estado tem encorajado o desenvolvimento da ciência?

A Propriedade Intelectual é baseada em monopólios temporários concedidos pelo Estado aos criadores de obras literárias, científicas e artísticas. Da mesma forma, as patentes podem ser definidas como o conjunto de direitos exclusivos concedidos aos responsáveis por inovações e invenções e inserem-se nos denominados direitos de Propriedade Industrial. Inicialmente, o surgimento da proteção legal à propriedade das ideias estava relacionado ao benefício social (COSTA, 2015).

O Estado concedia, por um tempo pré-determinado, o direto exclusivo de exploração aos criadores e, em contrapartida, a sociedade poderia desfrutar da criação. O objetivo era assegurar o contínuo fluxo do conhecimento, garantindo a incorporação das novas ideias pela sociedade e não a constituição de uma economia de monopólios. Segundo Silveira (2006), o monopólio temporário concedido aos inventores, responsáveis por inovações, era entendido como um mal necessário e um preço a ser pago. 
Foram os ingleses os primeiros a identificarem nos inventos e criações uma importante fonte de renda e instituíram os chamados royalties. Foi durante a revolução industrial que a Inglaterra aprimorou o sistema de cobrança de royalties, na oportunidade de exploração da invenção da máquina a vapor e, posteriormente, do motor a combustão. Estava criada a base da Propriedade intelectual (COSTA, 2015).

No contexto da Economia do conhecimento, tendo em vista o estudo sobre as externalidades, os "monopólios do conhecimento" são considerados externalidades positivas. Para Stiglitz (1999) as falhas de mercado são um problema que faz com que a economia de mercado gere um resultado que não maximiza a eficiência. O aquecimento global, em consequência da emissão de combustíveis fósseis, é um exemplo clássico do que economistas chamam de externalidade negativa. São justamente nessas falhas que o Estado age, e, normalmente, intervém. Uma externalidade ocorre sempre que ações de alguém pioram ou melhoram a situação de outra parte, sem que a outra parte assuma os "custos" ou "prejuízos" ou receba os "benefícios" de suas ações. O Estado intervém para que, em ambas as situações, de "prejuízos" ou "benefícios, tais ações não sejam prejudiciais ao desenvolvimento econômico e social de um país.

O financiamento das pesquisas é outra questão econômica relacionada à produção de conhecimento. Pesquisadores em todo o mundo sabem da importância de produzir artigos científicos. Muito disto está se dá pelo fato da produção cientifica estar relacionada com a distribuição de recursos financeiros, com a admissão em grupos de pesquisa e com os programas de pós-graduação (De Meis et al. 2003; Barré 2005).

Percebe-se a existência de uma relação entre o conhecimento científico, inovação e o desenvolvimento econômico. A inovação é posta como uma arma essencial na competição entre empresas e um meio para o crescimento econômico e o progresso da humanidade. Segundo Baumol (2002), o que mais diferencia a economia capitalista típica, de todas as outras formas de sistema econômico, são as pressões das forças de livre-mercado, que obrigam as empresas a um contínuo processo de inovação.

A Teoria da Inovação vincula-se, enquanto legado teórico, a Joseph Schumpeter, sendo reconhecido como um dos primeiros economistas a considerar as inovações tecnológicas como motor do desenvolvimento capitalista. Para ele, as longas ondas dos ciclos do desenvolvimento no capitalismo resultam da conjugação ou da combinação de inovações, que criam um setor líder na economia, ou um novo paradigma, que passa a impulsionar o crescimento rápido dessa economia (KLEINKNECHT, 1990).

Na teoria econômica sobre o desenvolvimento, segundo o enfoque Shumpeteriano, a concorrência não é o oposto de monopólio; a concorrência busca inovações que produzirão condições de monopólio, ainda que temporário. No entanto, a teoria econômica clássica aponta que os monopólios acabam reduzindo o ritmo das inovações.

De um lado temos os que defendem o modelo proprietário, alegando que a base da criatividade é a propriedade. Para eles é a propriedade que garante a produção continua de novos conhecimentos e inventos. A humanidade só teria interesse em criar se pudesse tirar das suas criações o máximo benefício econômico. Do outro lado estão os defensores do modelo livre, alegando que a base da criatividade é a liberdade e o compartilhamento de novas ideias. Para eles é a liberdade que garante a continua produção de novos conhecimentos. A história da ciência e seu avanço foi resultado de vários fatores, mas 
certamente o acúmulo contínuo do conhecimento e a troca livre de saberes foram elementos centrais na evolução cientifica. Isaac Newton, em uma frase célebre sobre a construção da ciência, disse: "Se eu vi mais longe, foi por estar de pé sobre ombros de gigantes" (COSTA, 2015).

É indiscutível a importância do compartilhamento ou disseminação do conhecimento científico para que novos conhecimentos possam surgir. Teorias são provisoriamente aceitas, até que sejam testadas, contestadas, revistas ou questionadas. Novas ideias põem em xeque paradigmas antes estabelecidos. Projetos inovadores em Tecnologia da Informação e Comunicação, como os baseados na construção de softwares livres, estão sendo realizados fora do modelo hegemônico de direitos de propriedade e da concessão de monopólios (Silveira, 2006).

Tais projetos têm gerado ganho economicamente distribuído entre os seus desenvolvedores. Esse ganho não se estabelece a partir das exigências dos direitos exclusivos ou monopólios do conhecimento e enfraquece o paradigma do monopólio econômico da exploração da obra ou invento como elemento primordial para a obtenção de ganho econômico e incentivo a criatividade e inovação. Abre um belo caminho para a chamada iniciativa de acesso aberto ao conhecimento. (Costa, 2014).

King (2004) destaca que o número global de artigos científicos publicados, em diferentes áreas do conhecimento, tem aumentado ao longo dos anos. Além disso, a produção científica das nações está relacionada com as características socioeconômicas dos países.

Associado ao aumento da produtividade científica, Nelson e Brammer (2008), destacam o aumento da participação feminina na produção cientifica. Holmgren e Schnitzer (2004), abordam o aumento da contribuição e da colaboração na produção cientifica nos países em desenvolvimento. Hudson (1996), já falava que o aumento de artigos em multiautoria estava sendo observado em várias áreas do conhecimento.

\subsection{0 movimento "Open Access"}

O Movimento de Acesso Aberto ao Conhecimento, como aponta Harnad (1995), começou como um movimento da comunidade científica que não se sentia representada pelas grandes editoras cientificas mundiais, que concentram grande parte da produção científica. Os interesses comerciais existentes por trás desses monstros da comunicação científica, as editoras científicas de luxo, colocaram em xeque a própria comunidade científica. Professores e pesquisadores levantaram o debate que está relacionado à mercantilização da ciência.

Tal movimento, iniciado em 2001, representava um esforço da Comunidade Científica, em frear a hegemonia das grandes Editoras Científicas. Hoje, após 15 anos, o movimento se consolida no mundo com a criação crescente e exponencial de periódicos científicos de acesso aberto, os chamados Open Access Journals, proposta defendida por Schekman (2013), que confirma o que Harnad (1995) já havia dito quando propôs os caminhos para implementação desse novo modelo, a Via Verde e a Via Dourada.

O Ipea tem um periódico de relativa idade, 37 anos, que responde exatamente à orientação do Conselho de Competitividade da União Europeia, anunciada em 27 de maio de 2016, 
que diz que todos os artigos científicos produzidos por instituições públicas europeias e custeados com recursos públicos, deverão adotar o modelo Open Access (OA) até 2020, modelo no qual não há cobrança pelo acesso aos conteúdos de periódicos científicos.

Um fato curioso chama a atenção durante o levantamento de dados desta pesquisa, observa-se que um grande número de "periódicos de destaque e renome", no contexto mundial da Comunicação Científica, começaram a estabelecer um novo "modelo de negócios" com base na ideia do "Movimento de Acesso Aberto ao Conhecimento".

As grandes e poderosas Editoras Científicas, ao se verem ameaçadas pelo "Movimento de Acesso Aberto", iniciaram, uma nova forma de cobrança, onde os autores ou universidades, ou instituições de pesquisa, continuam pagando a conta para que os resultados das pesquisas sejam referendados pelos pares, nessas grandes Editoras Científicas. Na prática observa-se que houve uma mudança de polo em relação ao ente científico que paga a conta para que os artigos estejam em Acesso Aberto. Antes pagavam as instituições de pesquisa, que precisam manter o seu corpo de pesquisadores atualizados sobre as novas descobertas, mantendo as assinaturas dos caros periódicos de acesso restrito, que coexistem com o outro modelo tradicional de acesso restrito.

No que se denominou "falso modelo de Acesso Aberto", adotado pelas grandes Editoras Científicas, o ente científico que paga a conta são justamente as instituições que fizeram as novas descobertas. Pagam para publicar em acesso aberto, assim terão eles próprios e toda a comunidade científica acesso amplo e livre aos seus resultados. A Science, por exemplo, cobra atualmente taxas que variam entre U\$ 3.000 a U\$ 5.000 por artigo a ser publicado em acesso aberto.

É preciso então diferenciar o Acesso Aberto em Repositórios de instituições científicas e o praticado pelos chamados Open Access Journals, do "Acesso Aberto" adotado por Editoras Científicas, responsáveis pela publicação dos "Periódicos de Luxo" ou "Periódicos Predatórios", como bem definiu Schekman (2013). A observação direta mostrou que eles se diferenciam quanto aos seus objetivos principais: os primeiros visam à publicação livre e sem barreiras dos resultados da ciência, os periódicos de luxo o lucro.

Percebe-se que as editoras científicas de renome apenas ampliaram seus modelos de negócios, tendo em vista as possibilidades advindas das novas tecnologias da comunicação e informação (a Busca), com base na filosofia capitalista, com foco na economia e no lucro, e fundamentada na exploração não só dos direitos autorais individuais, mas também na exploração de instituições de pesquisa no mundo todo.

Já os verdadeiros "periódicos de acesso aberto", pertencentes à Via Dourada de Hannard (1995), lançaram mão das oportunidades abertas pelas tecnologias da comunicação e informação (a Busca), com base na verdadeira filosofia do "Acesso Aberto", uma filosofia que caminha em sentido contrário, com foco na socialização da descoberta científica para que mais conhecimentos possam surgir. Os verdadeiros periódicos de Acesso Aberto não têm como objetivo principal o ganho econômico, mas o escoamento da produção científica represada, que não encontrou outros caminhos para romper as barreiras impostas pelas grandes Editoras Científicas.

Os verdadeiros periódicos de Acesso Aberto demonstram não abrir mão da adoção da "avaliação pelos pares", que têm um importante e indiscutível papel do ponto de vista da 
qualidade e da aceitação ou certificação de novos conhecimentos, como forma de garantir a qualidade dos trabalhos publicados. Eles cobram muitas vezes taxas simbólicas, se comparadas com os valores cobrados pelas grandes Editoras ou "Revistas de luxo". São periódicos científicos que se encontram fora do Modelo hegemônico de Comunicação Científica, fora do modelo estabelecido pelas revistas de luxo ou predatórias.

\subsection{Instituto de Pesquisa Econômica Aplicada (Ipea)}

Loureiro (1997) descreve o processo de criação do IPEA, com suas origens ainda na década de 1960. O objetivo seria de uma instituição voltada para políticas públicas, como um thinktank. Segundo a autora, "os institutos de pesquisa econômica aplicada", IPEA, IBRE, IPE, desempenharam um papel crucial: eles permitiram, de forma direta ou indireta, a produção da visibilidade dos economistas fora dos meios acadêmicos e enquanto interlocutores políticos, através da discussão pública sobre o significado dos indicadores econômicos produzidos e suas eventuais repercussões sobre a economia" (LOUREIRO, 1997).

Inicialmente, há relato de fortes vínculos entre a instituição e outros centros nacionais, como a Fundação Getúlio Vargas (FGV-RJ) e estrangeiros, inclusive com a vinda de pesquisadores colaboradores (CARVALHO, 1996). Essa tradição será mantida ao longo da história do órgão, tanto com fortes relações com universidades, com outros setores do governo, como com a Associação Nacional de Pós-Graduação em Economia (ANPEC). Dessa forma, na opinião de Loureiro (1997), "mais do que as próprias atividades de planejamento, o IPEA teve papel crucial na produção de conhecimento econômico no país, através de suas atividades sistemáticas de pesquisas aplicadas tanto em áreas macroeconômicas, quanto em área setoriais e sociais - agricultura, indústria, tecnologia, desenvolvimento regional, energia, mercado de trabalho, educação, saúde, previdência, etc."

Além do trabalho voltado para a formulação de políticas públicas e a produção de conhecimento científico, o IPEA também teve um papel importante na formação de quadros, por meio do Centro de Treinamento para o Desenvolvimento Econômico (CENDEC), com cursos de capacitação em planejamento econômico. Loureiro e Abrucio (1999) lembram que o Ipea foi um dos principais órgãos a fornecer quadros ao alto escalão para o Ministério da Fazenda. Complementarmente, sabe-se que muitos técnicos do instituto formam os quadros no Ministério do Planejamento e de outros órgãos da Administração Pública Brasileira (APB).

O Ipea é um instituto de pesquisa que integra a estrutura da Administração Pública Brasileira (APB) e tem mais de meio século de existência, são exatos 52 anos de idade, completados agora em 2016. O instituto foi criado em 1964, como Escritório de Pesquisa Econômica Aplicada, e somente assumiu o nome atual em 1967, quando se tornou fundação pública.

Parte da revitalização ocorrida no órgão após a crise das décadas de 1980 e 1990 é creditada a fontes alternativas de financiamento à pesquisa, como acordos com o PNUD, Banco Mundial e outros órgãos do governo, como a Fundação Banco do Brasil (LOUREIRO, 1997). O Programa Nacional de Pesquisa Econômica (PNPE) que permite o pagamento de bolsas também teve destaque. 
Loureiro (1997), entretanto, enfatiza a importância política atribuída ao órgão no governo Fernando Henrique Cardoso, assumindo um papel de assessoria técnica do Ministério do Planejamento, com caráter independente.

Segundo a autora,

"O traço particular que diferencia a assessoria fornecida pelo IPEA das demais assessorias dos ministérios governamentais é seu caráter independente. Hoje, como foi no passado, afirmam reiteradamente seus técnicos, o governo não interfere na produção de conhecimento gerado nesse instituto. Em outras palavras, as agências governamentais apenas solicitam as informações e análises produzidas pelo IPEA e as utilizam ou não conforme suas conveniências políticas, não impedindo inclusive a publicação de visões eventualmente contrárias a suas orientações” (LOUREIRO, 1997, p. 34).

O Ipea é hoje uma fundação pública vinculada ao Ministério do Planejamento, Desenvolvimento e Gestão. Encontramos uma das funções deste importante instituto brasileiro inscrita em uma de suas próprias publicações, datada de setembro de 2016 , que diz que "o Ipea fornece suporte técnico e institucional às ações governamentais, possibilitando a formulação de inúmeras políticas públicas e programas de desenvolvimento brasileiro, e disponibiliza, para a sociedade, pesquisas e estudos realizados".

O Ipea busca contribuir para o planejamento do desenvolvimento nacional, bem como para o melhor desenho e avaliação das políticas públicas, por meio da realização de estudos e pesquisas aplicadas e da disseminação do conhecimento resultante. Nesse contexto, percebemos o importante papel da pesquisa desenvolvida pelo órgão, que fornece apoio técnico e institucional ao governo e à sociedade, por meio da elaboração de relatórios, estudos e pesquisas que são importantes elementos para a solução de problemas e desafios de superação do subdesenvolvimento (BATISTA, et al. 2014).

O Ipea definiu ainda uma série de conceitos relacionados ao processo de planejamento estratégico institucional, dentre eles sua missão, valores e princípios, visão e formas de atuação. Como missão institucional, o Ipea se propõe a "produzir e disseminar conhecimento com a finalidade de aprimorar as políticas públicas essenciais ao desenvolvimento brasileiro". Dentre as formas de atuação do Ipea, destacamos: 1) desenvolver e disseminar estudos e pesquisas aplicadas; 2) subsidiar a elaboração de planos, políticas e programas governamentais; 3) acompanhar e avaliar os planos, as políticas e os programas governamentais; 4) assessorar processos decisórios de instituições governamentais; 5) realizar ações para a formação de quadros na gestão pública; 6) cooperar com governos e entidades nacionais e internacionais no seu campo de atuação.

O Ipea passou a ser conhecido, ao longo de sua existência, como uma das entidades que tem a "missão de pensar o Brasil". Os estudos e as pesquisas da instituição servem de subsídio ao governo federal no processo de implementação de políticas públicas, assim como nas atividades relacionadas ao planejamento do desenvolvimento brasileiro. Sabemos que a instituição dissemina conhecimentos produzidos por meio de diversas publicações, seminários e eventos, acordos de cooperação técnica, cursos, e etc.

Dentre as várias publicações do Ipea, podemos citar: 1) Texto para Discussão (TD); 2) Pesquisa e Planejamento Econômico (PPE); 3) Radar: Tecnologia, Produção e Comércio 
Exterior; 4) Carta de conjuntura; 5) Conjuntura em foco; 6) Boletim de Economia e Política Internacional; 7) Mercado de Trabalho: Conjuntura e Análise; 8) Políticas Sociais: Conjuntura e Análise; 9) Boletim Regional, Urbano e Ambiental; 10) Boletim de Análise Político-Institucional; 11) Brasil em Desenvolvimento (BD); 12) Planejamento e Políticas Públicas (PPP); e diversos 13) Livros. Nosso objeto de estudo pertence a esse conjunto de publicações do Ipea. A série periódica “Textos para Discussão (TD)" do Ipea é, reconhecidamente o principal canal de comunicação da instituição e por essa razão foi escolhida como objeto de estudo para esta pesquisa.

\subsection{A série periódica “Texto de Discussão (TD)" do Ipea}

A série periódica "Texto de Discussão (TD)" do Ipea chamava-se inicialmente "Texto para Discussão Interna" e teve seu primeiro número publicado em 1979. Apontada pelo próprio Ipea como sendo o seu principal canal de comunicação, responsável pela publicação de resultados de estudos e pesquisas realizados pelo órgão ao longo dos últimos 37 anos. Nesse sentido, não há dúvida de que os TDs do Ipea são um canal de comunicação muito relevante para o Ipea, para a Administração Pública e para a sociedade brasileira. Sendo uma série periódica de 37 anos de idade, a série "Texto para Discussão (TD)" do Ipea, além de ocupar o papel de importante canal de comunicação e divulgação da produção do Instituto de Pesquisa Econômica Aplicada (Ipea), mostrou-se muito relevante do ponto de vista da análise da série temporal como "Proxy de pesquisa" para o Ipea.

O TD 1000, (IPEA, 2004), é um dos dois trabalhos publicados pelo Ipea, com base na série, abordou e discutiu algumas questões ligadas à produção publicada até aquele momento, quando os TD completavam na ocasião seu milésimo fascículo. Esse estudo, realizado pelo próprio Ipea, compreendeu a análise de exatos 999 títulos, sendo o TD 1000 o título publicado com o resultado da historiografia. O objetivo daquela edição foi de "apresentar um registro da história do Ipea por meio das contribuições mais relevantes e inovadoras contidas nos TDs", onde ressaltam-se 1) novas metodologias de pesquisa; 2) instrumentos de análise de dados, com destaque para 3) novas abordagens econométricas e 4) análise de fenômenos sociais e 5) critérios de avaliação.

Neste fascículo de número 1000, o Ipea diz que os Textos para Discussão (TD) "são o mais genuíno meio de divulgação, circulação de ideias e de propostas de políticas públicas em curso na Instituição" e que "não seguem uma linha editorial específica, um rigor teórico e metodológico uniforme e, por isso mesmo, refletem, de maneira espontânea, a diversidade e o caráter interdisciplinar do Ipea". Para o Ipea, surge desta mistura de propósitos a série TD do Ipea, que são, para a instituição, a "expressão da heterogeneidade de linhas de pensamento existentes entre os técnicos do Instituto e das diferentes interpretações sobre os fenômenos econômicos e sociais correntes no país, ao longo do último quarto de século, a cada período e à sua época".

No TD 1000 a análise foi dividida em 28 áreas sobre as quais foi feito um breve comentário sobre as contribuições dos TDs até então. As áreas classificadas foram: agricultura; competitividade externa; desenvolvimento econômico; economia e demografia; economia internacional; economia regional e desenvolvimento econômico; educação; energia; finanças públicas; gasto público social; gestão pública; infraestrutura econômica; inovação tecnológica; macroeconomia e economia monetária; mercado de 
trabalho; métodos quantitativos; microeconomia; pobreza e desigualdade no Brasil; política e organização industrial; política e reforma tributária; política urbana, habitação, transporte e saneamento; previdência, seguridade e assistência social; privatização; reestruturação produtiva e competitividade; regulação ambiental; regulação econômica e defesa da concorrência; saúde; segurança pública e criminalidade.

O TD 1000, em comemoração aos 40 anos do Ipea, apresentou a evolução do pensamento econômico e social do Instituto de Pesquisa Econômica Aplicada (Ipea) sob a perspectiva dos Textos para Discussão (TD), publicados desde 1979."Ao longo de sua história, os técnicos do Ipea sempre produziram uma ampla variedade de trabalhos, publicados na forma de relatórios de pesquisa; livros; trabalhos acadêmicos divulgados nos melhores periódicos indexados, nacionais ou estrangeiros; o tradicional Boletim de Conjuntura; boletins de atividades setoriais; e notas técnicas para assessoramento da direção-geral do instituto e para diferentes órgãos do Poder Executivo". Integravam esta lista do Ipea em 2004 os Textos para Discussão (TD), à época a nossa série completava 25 anos de idade e estava na sua milésima edição.

A milésima edição foi resultado de um "esforço para resgatar as contribuiçõoes contidas nos TD” e levou à definição de áreas em que o Ipea tinha sido pioneiro. O TD 1000 destacou 1) a introdução de novos métodos de análise econômica; 2) a identificação de problemas e tendências econômicas e sociais ao longo do tempo; 3 ) os avanços da análise econométrica; 4) as técnicas de análise de problemas sociais; e 5) as propostas de medidas de política econômica relevantes eventualmente adotadas.

Os autores chamaram a atenção principalmente para contribuições metodológicas em diversas áreas e para uma tendência a temas de avaliação de política pública, além de forte influência da conjuntura macroeconômica de cada época: enquanto na década de 1970, o desenvolvimento econômico e políticas de industrialização eram tópicos bastante discutidos, ao longo da década de 1980, a crise da hiperinflação e os problemas fiscais do governo tomaram frente. Já na década de 1990, temas ligados à abertura comercial, competitividade de taxa de câmbio ganharam espaço, assim como questões relacionadas à política monetária com a adoção do regime de metas de inflação.

Um esforço de análise dos temas tratados nos TDs ao longo dos anos foi feito pela própria instituição, publicado como no TD 1000. A partir deste trabalho de 2004 pode-se perceber que há uma variedade grande de temas e objetivos nos mais de 1000 TDs existentes à época.

Em 2014, o Ipea publica outro trabalho com base nas contribuições contidas na série periódica Texto para Discussão (TD). O TD 2000, (IPEA, 2014), organizado a partir das seis diretorias de pesquisa do órgão, acrescenta, na ocasião do aniversário de 50 anos do Ipea, mais um capítulo à sua própria historiografia baseada na série. O TD 2000 faz uma exposição sucinta, mas significativa, dos trabalhos realizados pelo Ipea após a publicação do TD 1000. As seis diretorias do Ipea descreveram neste trabalho de 2014 suas contribuições a partir da organização de grandes temas.

Nas palavras do instituto, eles procuraram neste último trabalho "demonstrar a pujança do desenvolvimento das diversas linhas de pesquisa que realizamos neste período e as novas áreas temáticas que exploramos com a criação de duas diretorias, uma que trata de assuntos internacionais e seus impactos no nosso país e outra que estuda o Estado, sua 
ação e importância, procurando auxiliar no desenvolvimento da qualidade dos serviços prestados à população". O TD 2000 revela o esforço do Ipea em "estabelecer parcerias com os diversos órgãos setoriais de todos os poderes, que visam o assessoramento do governo federal para a criação, avaliação e modificação de políticas públicas essenciais ao desenvolvimento do país".

O primeiro capítulo do TD 2000, publicado sob a responsabilidade da Diretoria de Estudos e Políticas do Estado, das Instituições e da Democracia (DIEST) descreve a contribuição do Ipea em estudos e pesquisas relacionados aos seguintes temas: 1) papel do Estado e das instituições para fazer avançar a democracia e o desenvolvimento brasileiro; 2) mecanismos de democracia representativa e participativa e questões federativas; 3) o papel da organização e das capacidades do Estado para empreender as políticas públicas; 4) o desenho de instituições e de regulação de mercado para garantir o desenvolvimento ambiental sustentável e a provisão adequada de bens e serviços privados em situações nas quais há falhas de mercado; 5) principais contribuições do Ipea para o acesso à Justiça, incluindo o direito à segurança pública.

O segundo capítulo, publicado sob a responsabilidade da Diretoria de Estudos e PolíticasMacroeconômicas (DIMAC) descreve a contribuição do Ipea em estudos e pesquisas relacionados à área, mas de forma textual, não em tópicos. As contribuições e iniciativas da Dimac foram descritas de forma geral, evidenciando sua responsabilidade relativa aos estudos macroeconômicos e seu caráter interdisciplinar. Para a diretoria, a área macroeconômica deveincluir os aspectos macroeconômicos do mercado de trabalho e da política fiscal, abarcando ainda aspectos macroeconômicos do comércio e das finanças internacionais e das políticas de previdência e assistência social. Este capítulo aborda amplamente as estratégias de atuação da diretoria no decorrer dos últimos anos, tornando-se relevante do ponto de vista histórico.

O terceiro capítulo, publicado sob a responsabilidade da Diretoria de Estudos e Políticas Regionais, Urbanas e Ambientais (DIRUR), esclarece que a diretoria atua "em áreas multidisciplinares, que contêm o enfoque comum da análise espacial, do estudo do território e das implicações dos recortes administrativos". Além disso, apresenta sucintamente as contribuições mais relevantes do período posterior ao TD $1000 \mathrm{em}$ relação às questões urbanas e regionais, na escala das cidades e da região; acrescentando ao debate as implicações impostas pelos limites municipais e estaduais e o rebate federativo e, finalmente, subjacente ao território, investiga aspectos de sustentabilidade ambiental.

O quarto capítulo do TD 2000, publicado sob a responsabilidade da Diretoria de Estudos e Políticas Setoriais de Inovação, Regulação e Infraestrutura (DISET). A Diset destaca que "desenvolveu um conjunto extenso de trabalhos de pesquisa, pautada por uma linha de ação conectada com as preocupações presentes nas principais economias, a saber:a realização de análises sobre as causas, os condicionantes e os impactos dos processos de inovação tecnológica nas empresas, bem como avaliações das ações e políticas das instituições que apoiam o desenvolvimento científico e tecnológico. Este capítulo também aborda amplamente as estratégias de atuação e as parcerias estabelecidas no decorrer dos últimos anos pela diretoria, tornando-se relevante do ponto de vista histórico.

O quinto capítulo, publicado sob a responsabilidade da Diretoria de Estudos e Política Sociais (DISOC)abre o capítulo apresentando sua competência regimental e descreve a 
contribuição do Ipea em estudos e pesquisas relacionadas às áreas de políticas sociais, a partir das três principais linhas de atividade estruturantes da Disoc, a saber: 1) o acompanhamento e monitoramento das políticas sociais; 2) a análise da situação social; e 3) o assessoramento ao governo e avaliação de programas.Demonstra seu caráter interdisciplinar e destaca a contribuição do Ipea em estudos e pesquisas relacionados aos seguintes temas: Previdência, Assistência Social e Desigualdade e Pobreza; Saúde; Educação; Trabalho e Renda; Cultura; Desenvolvimento rural e Igualdade racial e igualdade de gênero.

Por fim, mas não menos importante, o sexto capítulo, publicado sob a responsabilidade da Diretoria de Estudos e Relações Econômicas e Políticas Internacionais (DINTE), descreve a contribuição do Ipea a partir da estrutura interna da diretoria, a Coordenação de Estudos em Relações Econômicas e Políticas Internacionais (Corin) e a Coordenação de Estudos em Instituições e Governança Internacional (Cogin). Segundo a Dinte, a Corin "trabalha com temas da agenda econômica internacional, especialmente relativos: ao comércio internacional, investimentos externos diretos, sistemas monetário e financeiro internacionais, governança econômica global, integração regional, em sua dimensão econômica". Já a Cogin "consolidou ao longo dos últimos cinco anos uma agenda de pesquisa diversificada, que se estrutura em torno de três grandes eixos: a cooperação internacional brasileira e internacional para o desenvolvimento; a integração sulamericana e as relações da região com os demais países da América Latina e do Caribe; e a defesa nacional e a segurança no entorno estratégico brasileiro".

Como percebemos, a série periódica Texto para Discussão (TD) do Ipea foi explorada pelo próprio instituto do ponto de vista das colaborações relevantes de estudos e pesquisas realizados e publicados em forma de TD. Esses dois trabalhos, o TD 1000/2004 e o TD 2000/2014, reuniram a produção com o objetivo de apresentar à sociedade o resultado concreto da produção do Ipea, de forma sucinta e resumida. A partir desses trabalhos é possível verificar pontualmente as contribuições mais relevantes ao longo dos anos. Podem ser consideradas como parte da historiografia do Ipea e foram publicadas na ocasião da comemoração dos 40 e 50 anos do instituto.

Este estudo se diferencia dos dois acima pelos objetivos diversos que propusemos. Não fizemos uma análise profunda e especializada dos estudos e pesquisas como a realizada pelos TDs 1000 e 2000; ao contrário, como veremos, tomamos para esta pesquisa outros dados e outros aspectos desta rica série periódica brasileira, chamada Texto para Discussão (TD). 


\section{METODOLOGIA}

A metodologia foi desenvolvida para se cumprir os seis objetivos propostos, visando a elaboração dos resultados da análise formal, da análise quantitativa-descritiva e da análise qualitativa. $\mathrm{Na}$ análise formal lançamos mão do levantamento bibliográfico a da análise documental para caracterização do objeto. A análise quantitativa-descritiva foi realizada por meio da coleta de dados sobre a série temporal e construção do banco de dados, feita a partir da análise de coautoria. A análise qualitativa foi realizada por meio de entrevistas, que foram realizadas com o intuito de melhorarmos as observações qualitativamente.

\subsection{COLETA E CONSTRUÇÃO DA BASE DE DADOS}

A construção do banco de dados foi realizada a partir da coleta de dados da série TD do Ipea em diversas páginas web. Incialmente coletamos dados na página do Repositório do Conhecimento do Ipea (RCIpea) www.repositorio.ipea.gov.br; no Portal Ipea http://www.ipea.gov.br/portal/ e na página Domínio Público http://www.dominiopublico.gov.br/.

Para complementarmos as buscas relativas aos dados que levantamos para a pesquisa e para excluirmos dúvidas relativas aos dados coletados, principalmente na análise de detalhes relativos a coautoria e à vinculação, foram consultados em alguns casos os resumos e sumários executivos da série e em muitos casos os próprios fascículos dos Textos para Discussão (TD), nossa fonte principal de informação para a construção da base de dados da pesquisa.

A amostra da pesquisa, totalizando $\mathbf{2 . 2 0 3}$ títulos da série periódica, foi complementada e atualizada até o dia 01/07/2016, data limite estabelecida para que os últimos 40 fascículos fossem integrados a amostra da pesquisa para uma completa análise de coautoria.

\subsection{ANÁLISE DA SÉRIE TEMPORAL}

Para a análise da série temporal, utilizou-se o software Excel e suas funcionalidades para análise de dados. Recorreu-se ao software para organização do banco de dados da pesquisa, utilizando-se da ferramenta de análise estatística para calcularmos a correlação entre as variáveis PATD e o número de pesquisadores envolvidos nos estudos e pesquisas a cada ano.

Reunimos informações relacionadas aos períodos de gestão para analisarmos em detalhes a produção do Ipea nos últimos 37 anos. As tendências de multiautoria e autoria única foram observadas a partir da utilização dos dados contidos no banco de dados da pesquisa.

\subsection{ANÁLISE QUANTITATIVA POR ÁREA TEMÁTICA}

Em relação à tarefa de classificação dos trabalhos publicados, optou-se por utilizar o Código de Classificação do Journal of Economic Literature (JEL), o chamado "Journal of Economic Literature Classification System (JELCS)". Utilizamos as 20 (vinte) categorias de assunto definidas pelo JELCS, no primeiro nível de organização do conhecimento. A classificação temática foi realizada no decorrer da pesquisa, com base 
nas informações descritivas dos itens, nos seus resumos e conteúdos. Cada item recebeu apenas um assunto, tendo em vista alguns dos trabalhos abrangerem e poderem ser classificados em mais de uma área do conhecimento.

Tabela 1 - Categorias de Assuntos - JELCS

\begin{tabular}{|l|}
\hline \multicolumn{1}{|c|}{ Categorias } \\
\hline (A) Economia Geral e Ensino da Economia \\
\hline (B) História do Pensamento Econômico, Metodologia e Abordagens Heterodoxas \\
\hline (C) Matemática e Métodos Quantitativos \\
\hline (D) Microeconomia \\
\hline (E) Macroeconomia e Economia Monetária \\
\hline (F) Economia Internacional \\
\hline (G) Economia Financeira \\
(H) Economia Pública \\
\hline (I) Saúde, Educação e Bem-Estar \\
(J) Trabalho e Economia Demográfica \\
\hline (K) Direito e Economia \\
\hline (L) Organização Industrial \\
(M) Administração de Empresas e Economia Empresarial, Marketing e Contabilidade \\
\hline (N) História Econômica \\
(O) Desenvolvimento Econômico, Mudança Tecnológica e Crescimento \\
\hline (P) Sistemas Econômicos \\
(Q) Economia Agrícola e de Recursos Naturais \\
(R) Economia Urbana, Rural e Regional \\
(Y) Categorias Variadas \\
(Z) Outros Tópicos Especiais \\
\hline
\end{tabular}

Nota: Tabela elaborada pela autora.

Ressalta-se que, apesar dos técnicos entrevistados acharem que poderíamos apresentar este resultado por apenas 10 categorias de assunto, a tarefa de sintetizar as 20 categorias principais em apenas 10 categorias, alteraria a estrutura básica deste importante Código de Classificação para a tarefa, o que pensamos não ser adequado. Além do mais, se considerarmos a diversidade temática dos estudos e pesquisas do Ipea, classificar os TDs a partir das 20 categorias do JELCS já é uma tarefa difícil, tendo em vista o foco do JELCS na área Econômica. Classificar por 10 categorias prejudicaria o resultado final almejado, uma vez que nos forçaria a encaixar determinados estudos em categorias temáticas ou muito genéricas ou muito específicas.

O esforço de classificar os TDs por temas foi realizado a partir da indexação de 2.203 fascículos coletados até 01 de julho de 2016. Os dados foram organizados por períodos de gestão, a partir da elaboração de gráficos que continham os temas e os anos de publicação, proporcionando uma visão gráfica dos estudos e pesquisas realizados ao longo dos 37 anos da série temporal. 


\subsection{ANÁLISE FORMAL}

$\mathrm{Na}$ análise formal lançou-se mão do levantamento bibliográfico a da análise documental para caracterização do objeto. Identificamos na literatura a maior parte das características listadas, resultado da coleta de dados na bibliografia especializada consultada, que compõe o referencial teórico desta pesquisa. Em seguida elaborou-se um quadro com as 52 (cinquenta e duas) características gerais encontradas em séries periódicas, periódicos e canais de comunicação para publicação de resultados de estudos e pesquisas.

\subsection{ANÁLISE DA REDE IPEA}

A análise quantitativa-descritiva foi realizada por meio da coleta de dados sobre a série temporal e construção do banco de dados, feita a partir da análise de coautoria.

Para a análise da rede Ipea, na fase inicial da pesquisa, a organização de todo o banco de dados da pesquisa foi realizada com a ajuda do software Excel. A série analisada contém 2.203 títulos ao todo, escritos por cerca de $\mathbf{1 . 4 1 0}$ autores. Os dados para a análise quantitativa da série temporal considerados nesta pesquisa vão até dezembro de 2015. A amostra quantitativa totalizou $\mathbf{2 . 2 0 3}$ trabalhos, publicados em 37 anos de existência da série. Foram excluídos 963 fascículos, escritos em autoria única, dispensados apenas para a análise da Rede, uma vez que apenas as relações de coautoria nos interessavam. A amostra relevante para a análise da rede foi composta por 1.237 trabalhos escritos em coautoria e publicados na série periódica em 37 anos de sua existência. Não havia como inserir os trabalhos em autoria única para a análise de rede, visto que são exatamente as relações de coautoria que forneceram os dados para análise das redes.

A padronização dos autores foi uma das tarefas mais trabalhosas na construção da base de dados da pesquisa. Depois de organizarmos os dados resultantes da análise de coautoria em uma sequência que obedeceu a ordem em que os autores foram citados nos créditos dos trabalhos, padronizou-se o nome dos autores para que a construção da rede fosse possível e não constasse atores duplicados, que poderiam ser interpretados como nós diferentes da rede. Essa etapa foi fundamental, por exemplo, para que a real importância de alguns "vértices", que desempenham papéis de "cutpoints" na Rede, fosse correta na análise da rede. A amostra relevante para análise da rede foi organizada em colunas, de acordo com a quantidade de autores responsáveis pela autoria dos trabalhos. As "sub-redes" tiveram de 2 a 14 atores em coautoria. Foram necessárias 9 colunas para essa tarefa, que acomodaram os atores em trabalhos com 2, 3, 4, 5, 6, 7, 8, 9 e 14 autores. A padronização foi realizada entre os autores em cada coluna e entre todas as colunas. Atribuiu-se um código numérico de seis dígitos para cada autor. A codificação dos autores permitirá a elaboração de trabalhos com os resultados desta pesquisa, preservando-se a identidade dos autores do Ipea.

Após essa etapa de construção e padronização do banco de dados, passamos para a construção das relações de coautoria em formato de matrizes quadráticas. As matrizes foram construídas a partir do recorte que fizemos, dividindo os dados de 37 anos em quatro períodos. Foram construídas matrizes quadráticas para os quatro períodos, por meio da utilização de códigos binários. Os autores de cada período foram colocados na primeira coluna e na primeira linha das planilhas Excel, formando as matrizes quadradas. 
Atribuímos valores binários que representaram a presença ou a ausência da relação de coautoria. Foi atribuído o número "1" para cada relação de coautoria existente e o número "0" para as coautorias que não aconteceram. As matrizes foram utilizadas para que pudéssemos inserir os dados no software UCINET 6.6 for Windows. O editor de planilha do UCINET pode importar e exportar as planilhas do Excel. Cada conjunto de dados consiste em dois arquivos separados que contêm informações do cabeçalho, por exemplo, arquivo.\#\#; e as linhas, por exemplo, arquivo.\#\#d.

A organização e a sistematização dos dados coletados para mapeamento das redes de coautoria foram realizadas com a utilização deste software UCINET 6.6 (BORGATTI: EVERETT; FREEMAN, 2002). O UCINET é frequentemente usado por pesquisadores para análise de redes por conter uma série de rotinas analíticas de redes, que permitem a análise dos grafos e o mapeamento das relações de coautoria. As funcionalidades do UCINET permitiram a extração de dados em arquivo texto, tais como a centralidade de grau dos vértices, o grau de intermediação e a formação dos blocos das redes. Para o desenho e visualização das redes utilizamos o software NetDraw 2.1, que vem integrado ao UCINET.

A centralidade de grau é a medida da centralidade do indivíduo a partir do número de conexões com outros atores da rede. Em matrizes com relações não dirigidas, simétricas ou recíprocas, o grau de centralidade consiste na quantidade de relações ou conexões existentes para cada ator. No UCINET, essa medida pode ser calculada pela rotina: Network > Centrality > Degree.

A centralidade de intermediação indica o ator que tem o controle sob a interação entre dois atores não adjacentes na rede. A intermediação de um nó é obtida ao se contar o número de vezes em que ele aparece nos caminhos geodésicos que conectam os pares de atores da rede. No UCINET, essa medida pode ser calculada pela rotina: Network > Centrality > Betweenness > Nodes. 


\section{RESULTADOS}

\subsection{Resultados: a descoberta da série temporal Texto para Discussão (TD) do Ipea}

Ao olharmos para a "série temporal" construída a partir da publicação dos Textos para Discussão (TD) do Ipea, nos últimos 37 anos, foi possível observar o comportamento da variável "TDs publicados" ao longo dos anos, e percebemos que uma explicação possível poderia ser dada aos fenômenos observados, com base em sua linha de tendência.

Do ponto de vista da análise quantitativa, explorada em 37 anos de existência da reconhecida série periódica no contexto acadêmico nacional, a série temporal, parece explicar questões relacionadas à produção do Ipea, que parecem estar ligadas a variáveis internas e externas. Durante o fechamento desta pesquisa apresentamos a "Proxy de desempenho" para alguns pesquisadores do Ipea, com objetivo de avaliarem a descoberta e concederem entrevista para complementarmos as observações qualitativamente. Foram apontadas pelos pesquisadores variáveis internas que claramente explicavam as variações observadas.

Foram citadas as seguintes variáveis: 1) o número de pesquisadores; 2) o número de bolsistas; 3) a realização de concursos para técnicos de desenvolvimento e técnicos de pesquisa; 4) a realização de mestrados e doutorados pelos pesquisadores e servidores, etc. Algumas variáveis externas foram espontaneamente citadas pelos pesquisadores, que observaram, por exemplo, o efeito da estabilidade político-institucional, propiciada pela continuidade de alguns presidentes do Ipea, na PATD.

Gráfico 1 - Produção Anual de Textos para Discussão do Ipea (PATD) e sua Linha de Tendência (linear)

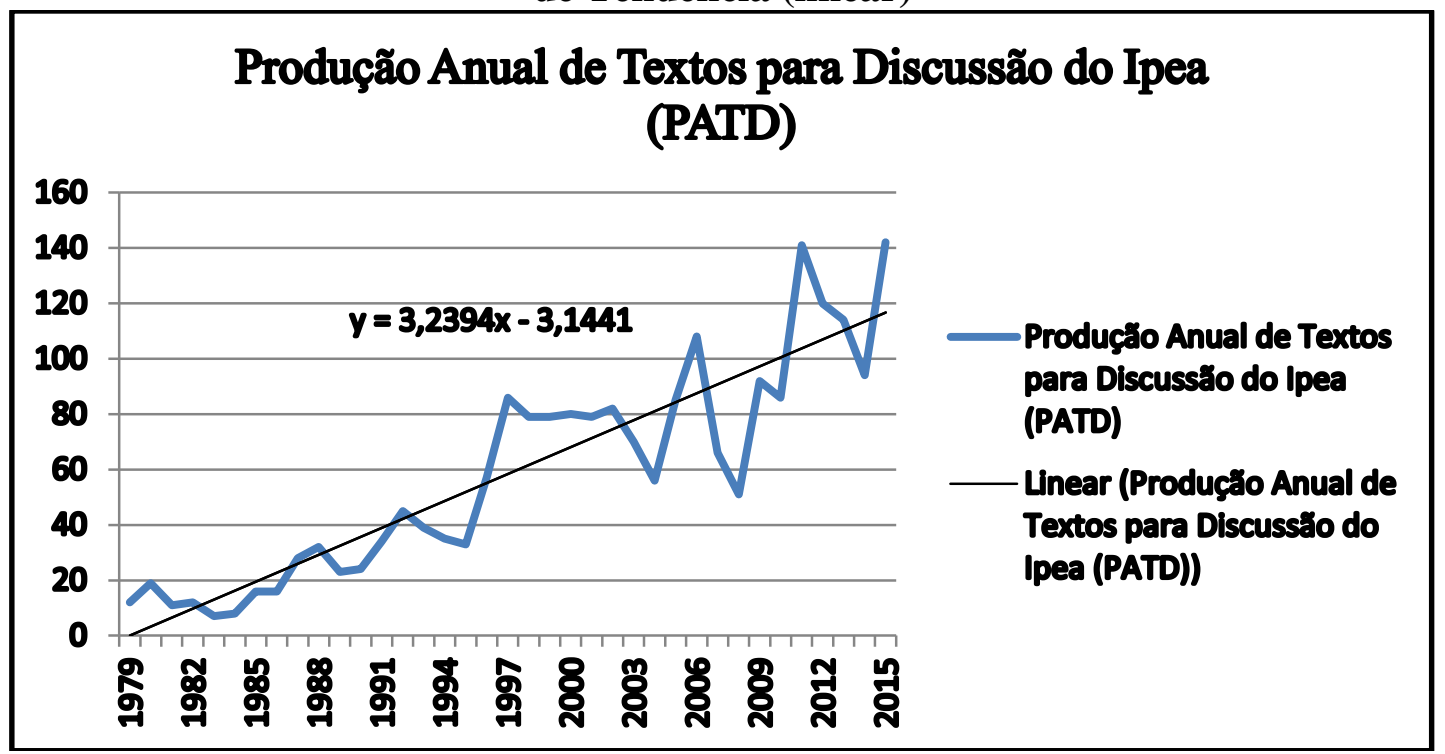

Nota: Elaboração da autora.

Percebe-se que a série temporal, referente à Produção Anual de Textos para Discussão do Ipea (PATD), descrita no gráfico 1, é naturalmente um indicador do desempenho da instituição. Podemos utilizá-la para medir o desempenho do Ipea ao longo do período. 
Podemos dizer que a "Produção Anual de Textos para Discussão do Ipea (PATD)" é determinada pela soma dos de todos os TD produzidos nos 12 meses do ano. Podemos então escrever a seguinte função matemática determinada, como lei de formação da série temporal $\mathrm{Yt}_{\mathrm{t}}$

$\mathbf{Y}_{\mathbf{t}}=\mathrm{Jant}+\mathrm{Fevt}+$ Mart + Abrt + Mait + Jut + Jult + Agot + Sett + Outt + Novt + Dezt

O gráfico 2 abaixo, apresenta os dados coletados da variável PATD, observados e coletados ao longo dos 37 anos de existência da série periódica, foram organizados por ano. Foi a partir da observação deste gráfico que percebemos que poderíamos utilizar esses dados, os dados da série temporal, para entendermos o desempenho do Ipea. Podemos dizer que uma série temporal é uma coleção de observações feitas sequencialmente ao longo do tempo. Sabíamos que em séries temporais a ordem dos dados é fundamental. Tínhamos nas mãos essa rica sequência de observações.

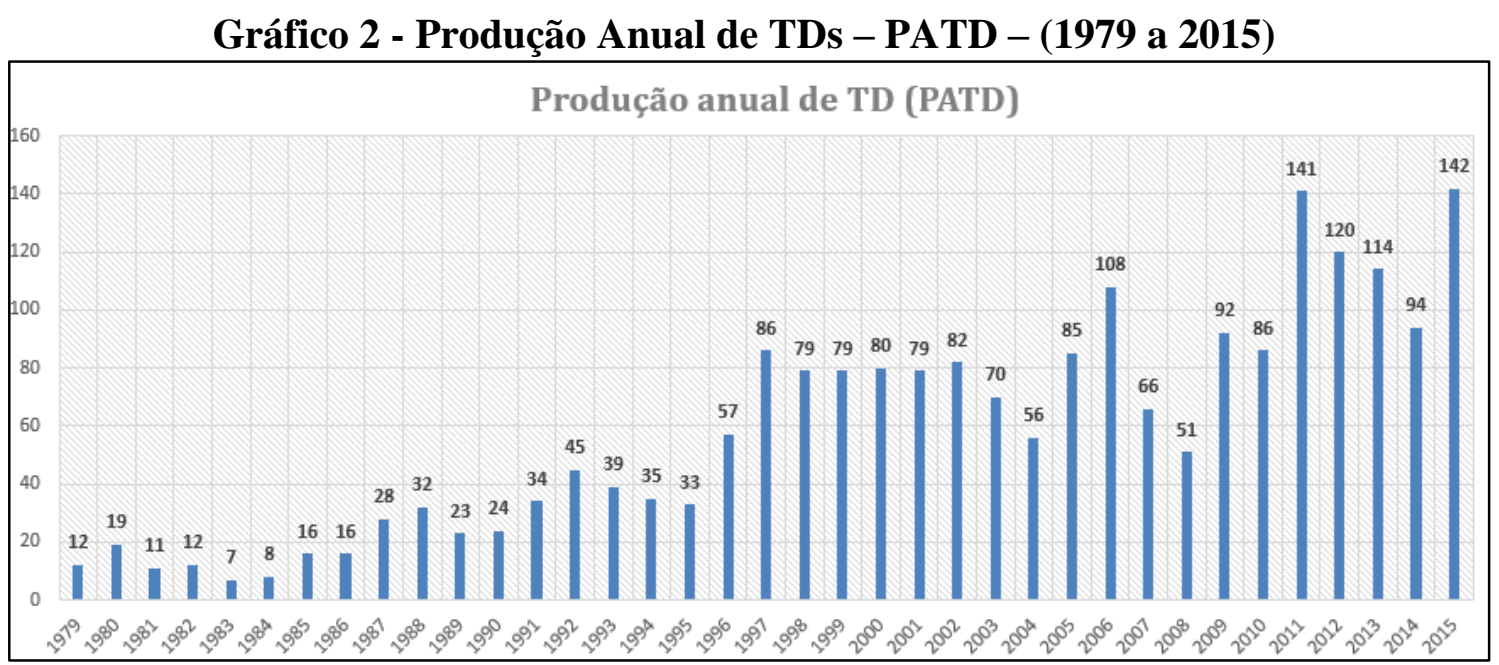

Nota: Elaboração da autora. 


\subsection{Resultados: análise da série temporal}

Observa-se que durante um longo período, de 1979 a 1995, cerca de 16 anos, a variável observada apresentou um pequeno incremento. A PATD, permanecendo abaixo dos valores médios esperados. Em 1995 a variável observada PATD alcançou o número de 86 publicações no ano. No gráfico 1, pode-se observar esse comportamento da variável. A linha de tendência, com coeficiente angular positivo, mostra esse comportamento crescente da variável.

Ao entrevistarmos alguns pesquisadores do Ipea, com objetivo de complementarmos as observações qualitativamente, fomos coletamos informações sobre outras variáveis internas que pudessem explicar esse comportamento. Em entrevista, os pesquisadores do Ipea, Alexandre Xavier Ywata e Lucas Mation, ao se depararem pela primeira vez com a série temporal, buscaram explicar as razões que poderiam ter influenciado o incremento da PATD a partir de 1995. Relataram os pesquisadores do Ipea que uma das explicações possíveis para o incremento observado a partir de 1995 e parao pico de 1997, tem relação com a realização de concursos públicos para contratação de pesquisadores. Os entrevistados relataram que claramente percebiam que os outros concursos públicos subsequentes realizados pelo Ipea também pareciam ter influenciado esse incremento na PATD.

O gráfico 3 mostra como evoluiu o número de pesquisadores autores de TDs, por ano, no período considerado e sua linha de tendência:

\section{Gráfico 3 - Produção Anual de Textos para Discussão do Ipea (PATD) e sua Linha de Tendência (linear)}

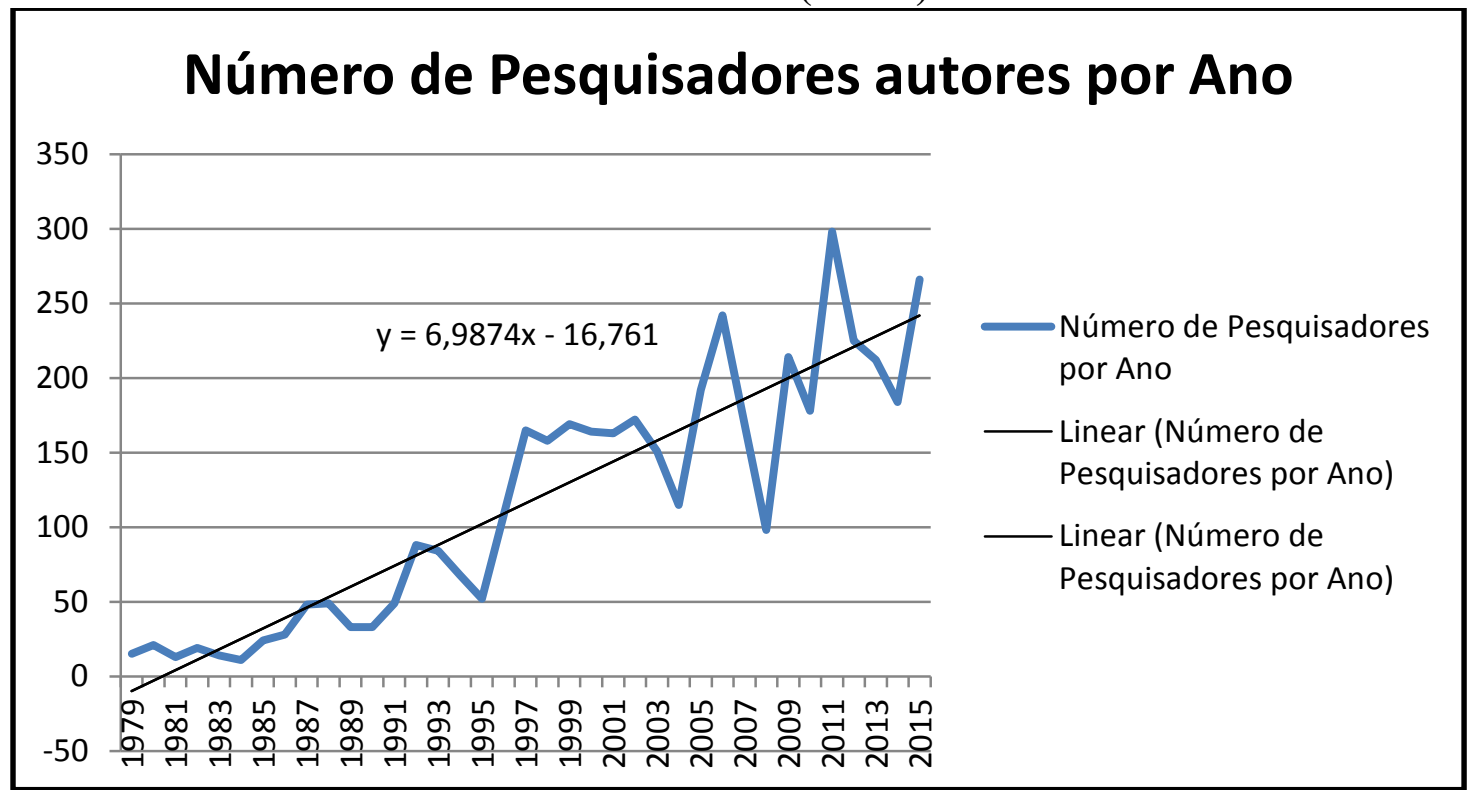

Nota: Elaboração da autora.

Observa-se que aqui também o coeficiente angular da linha linear de tendência é positivo, porém maior que o da variável referente ao número de publicações, o que indica um crescimento mais acelerado do número de pesquisadores na média no período. 
Após o período de recuperação histórica, que durou cerca de dois anos, 1995-1997, seguiu-se um longo período de estabilização, que durou de 1997 a 2002, todo o período compreendido na gestão de Fernando Henrique Cardoso. Como vimos a variável PATD se manteve em comportamento estável, de, aproximadamente, 1997 a 2002. No gráfico referente a esta variável pode-se ver um platô correspondente a esse período. Em 2002, ano de eleições presidenciais no Brasil, percebemos que a variável sofre um impacto e volta a cair. Por alguma razão a variável PATD se comportou de forma "negativa" no período que consideramos de transição entre os governos de FHC e Lula.

A variável PATD começou a cair em 2002 e permaneceu em queda até 2004. Isso nos leva a crer que esse período, que nomeamos, inicialmente, de "período de transição político-administrativo brasileiro" por alguma razão, teve impacto no comportamento da variável descoberta. Isso pode ter relação com outras variáveis desconhecidas, que mostram ter influência sobre a variável Y. Essa variação observada pode levar ao estudo de variáveis que possam ter tido uma influência em Y, ou seja, no aprofundamento da análise, que não será objeto desta dissertação, podem-se testar variáveis que "explicam" essa influência que PATD sofreu nesse "período de transição político-administrativo brasileiro", de durou cerca de 3 anos, 2002 a 2004.

Em entrevista, os pesquisadores Alexandre Xavier Ywata e Lucas Mation relataram achar interessante a variação da PATD no período. Para os pesquisadores, outras variáveis podem explicar o incremento e a redução da PATD. Os pesquisadores relataram acreditar que os picos de 1997, 2006 e 2011 tem relação com a realização dos concursos públicos do Ipea. Os pesquisadores observaram, por meio da série temporal, que os incrementos na PATD vinham seguidos de baixas na produção. Com exceção do período do platô de FHC, todos os outros incrementos foram seguidos de quedas da PATD. Para os pesquisadores, a manutenção das médias da PATD no período FHC tem relação com a "desova" ou publicação de dissertações e teses dos pesquisadores. Para eles, essa é uma outra importante variável que explica o comportamento da PATD no período. Para os pesquisadores, para entendermos como a PATD se comporta, deveremos coletar também informações sobre a promoção de cursos de mestrado e doutorado pelo Ipea e os períodos em que os resultados desses cursos são publicados em forma de TD.Para os pesquisadores, a série apresenta uma marcada sazonalidade, com produção muito elevada nos meses seguintes a concursos e produção de teses e dissertações.

Em entrevista, o pesquisador Luiz Cezar Loureiro de Azeredo observou que os picos de FHC, Lula e Dilma podem estar relacionados a uma outra variável, a estabilidade políticoinstitucional interna do Ipea. Nesse sentido, procurou-se coletar e organizar os dados dos períodos de gestão de cada um dos presidentes do Ipea para o período analisado. Como pode-se observar na tabela abaixo, a partir dos dados coletados, durante todo o período de gestão de FHC, de 1995 a 2002, exatos 8 anos, passaram pelo Ipea 3 (três) presidentes, que tiveram 13, 35 e 47 meses de gestão. Em 1997, na gestão de Fernando Antônio Rezende da Silva, que permaneceu no cargo por 35 meses, a PATD superou todos os valores antes alcançados, definindo um novo parâmetro para a variável. 
Tabela 2 - Presidentes do Ipea por período de gestão

\begin{tabular}{|c|c|c|}
\hline Presidente do Ipea & Periodo de Gestão & $\begin{array}{c}\text { Periodo de } \\
\text { gestão em } \\
\text { meses }\end{array}$ \\
\hline Marcos Amorim Neto & $15 / 03 / 1979$ a $15 / 08 / 1979$ & 5 meses \\
\hline José Flávio Pécora & $15 / 08 / 1979$ a $14 / 03 / 1985$ & 66 meses \\
\hline Andrea Sandro Calabi & $18 / 03 / 1985$ a $12 / 03 / 1986$ & 11 meses \\
\hline Henri Philippe Reichstul & $12 / 03 / 1986$ a $15 / 04 / 1987$ & 13 meses \\
\hline Michal Gartenkraut & 29/04/1987 a $25 / 01 / 1988$ & 9 meses \\
\hline Ricardo Luís Santiago & 01/02/1988 a 01/03/1990 & 24 meses \\
\hline Antônio kandir & 05/04/1990 a 13/05/1991 & 13 meses \\
\hline Roberto Brás Matos Macêdo & 23/05/1991 a 03/10/1992 & 17 meses \\
\hline Líscio Fábio de Brasil Camargo & 10/11/1992 a 04/03/1993 & 4 meses \\
\hline Antônio Nilson Craveiro Holanda & 01/04/1993 a 08/06/1993 & 2 meses \\
\hline Aspasia Brasileiro A. de Camargo & 09/06/1993 а 01/01/1995 & 18 meses \\
\hline Andrea Sandro Calabi & $11 / 01 / 1995$ a 09/02/1996 & 13 meses \\
\hline Fernando Antônio Rezende da Silva & 09/02/1996 a 18/01/1999 & 35 meses \\
\hline Roberto Borges Martins & $18 / 01 / 1999$ a $01 / 01 / 2003$ & 47 meses \\
\hline Glauco Antonio Truzzi Arbix & 05/03/2003 a $22 / 05 / 2006$ & 38 meses \\
\hline Luiz Henrique Proença Soares & $22 / 05 / 2006$ a $13 / 08 / 2007$ & 14 meses \\
\hline Marcio Porchmann & $14 / 08 / 2007$ a 04/06/2012 & 58 meses \\
\hline Vanessa Petrelli Corrêa & 05/06/2012 a $11 / 09 / 2012$ & 3 meses \\
\hline Marcelo Cortes Neri & $12 / 09 / 2012$ a $05 / 05 / 2014$ & 20 meses \\
\hline Sergei Suarez Dillon Soares & $21 / 05 / 2014$ a $01 / 04 / 2015$ & 11 meses \\
\hline Jesse Jose Freire de Souza & 02/04/2015 a $18 / 05 / 2016$ & 13 meses \\
\hline Manoel Carlos de Castro Pires & $18 / 05 / 2016$ a $01 / 06 / 2016$ & 0 meses \\
\hline Ernesto Lozardo & 01/06/2016 a 31/06/2016 & 01 meses \\
\hline
\end{tabular}

Nota: Tabela elaborada e dados trabalhados pela autora.

Em relação a essa questão, os pesquisadores Alexandre Xavier Ywata e Lucas Mation observaram também que os picos do período de gestão de Marcio Porchmann, que esteve a cargo da presidência do Ipea por 58 meses, mudaram o patamar da variável PATD. Os pesquisadores apontaram que o comportamento estável da PATD no período de FHC e os picos posteriores e o novo patamar podem estar relacionados com os programas de bolsas de pesquisa implementados pelo Ipea. Para os pesquisadores, os bolsistas do Ipea, que podem ser considerados parte do "capital intelectual humano" do Ipea, desempenham funções auxiliares de pesquisa que certamente têm relação com o incremento da PATD.

Percebe-se que, antes de Porchmann, apenas José Flávio Pécora havia ficado por maior período na presidência do Ipea, totalizando 66 meses. No entanto, observa-se que neste último caso, a PATD não sofreu incremento. De fato, de 1979 a 1986, a PATD se manteve sem incrementos que pudessem ser relacionados a estabilidade institucional do Ipea. Se há de fato correlação entre essa questão e a PATD, somente um estudo mais aprofundado poderá revelar.

Durante todo esse período inicial da série periódica Texto para Discussão (TD), o Ipea passava pelo período que ficou marcado pelas tentativas frustradas de controle da inflação. A partir de 1986, começamos a observar um pequeno incremento na PATD, se comparados a todo o período anterior. Para um dos pesquisadores entrevistados, Luiz Cesar Loureiro de Azeredo, a partir de 1986, com o movimento popular de Diretas Já, houve um redirecionamento e um novo posicionamento institucional do Ipea. Para o pesquisador, a partir de 1986, outros direcionamentos foram dados ao órgão que o levariam a produzir mais e mais estudos e pesquisas. 
Pode-se observar que a variável PATD começa novamente a sofrer um importante incremento em 2004. Em 2005 alcança o mesmo patamar dos maiores valores até então observados, registrando 85 publicações. Em 2006, na gestão de Luiz Inácio Lula da Silva, o Ipea tem a sua maior produção anual de TD da história do Ipea registrados até então. São publicados, em 2006, 108 trabalhos. Estudar separadamente outras séries correspondentes em períodos equivalentes poderá nos ajudar a entender esse comportamento, que na opinião dos pesquisadores entrevistados, tem relação com a promoção de mais um concurso público e a contratação de mais pesquisadores.

Em 2008, por alguma razão, a queda da PATD foi bem representativa e chamou a atenção dos pesquisadores. O fato é que a partir de 2008, ano da grande crise internacional, marcada pela falência do "Lehman Brothers", e que atingiu todo o mundo, a variável PATD começou um novo ciclo de ascensão. Para eles, a série apresenta uma marcada sazonalidade, com produção muito elevada em determinados períodos, seguida nos meses subsequentes de acentuada queda. A PATD foi de 51 publicações em 2008 e em 2009 registrou um incremento considerável, tendo o Ipea publicado 92 fascículos da série periódica neste ano.

No ano de 2010 notamos que a variável PATD sofreu uma pequena queda, que coincidentemente ou não, ocorreu em um período, que nomeamos de "período de transição político-administrativo brasileiro". Após essa pequena queda, a variável volta a sofrer um grande incremento e alcança em 2011, já no governo de Dilma Rousseff, o maior valor registrado em 32 anos. A PATD alcança em 2011 o valor de 141 trabalhos publicados. Nos anos de gestão de Dilma Rousseff, de 2011 a 2015, a PATD do Ipea se manteve em um patamar bem alto. O menor valor observado para o período foi o de 94 trabalhos publicados em 2014. Mesmo esse valor de 2014, o menor de todo o período de gestão de Dilma, é bem alto se comparado a média da produção de todo o período de FHC e Lula. Para o Ipea abre-se a possibilidade para entender os fatores que podem ter contribuído para o aumento observado nos últimos 5 anos.

Em 2015 o Ipea mostra um desempenho ainda superior ao registrado em 2011.No último ano o Ipea registrou o maior valor para toda a série temporal, foram publicados 142 trabalhos. Em entrevista, esse último registro da série chamou a atenção do pesquisador Alexandre Xavier Ywata. Para o pesquisador, todos os outros incrementos observados parecem ter relação com a realização de concursos públicos, com exceção desse último pico de 2015, que aparentemente não tem relação com o aumento do número de pesquisadores. Uma hipótese levantada pelo pesquisador diz respeito ao fortalecimento dos programas de concessão de bolsas para alunos de graduação e pós-graduação e ainda para pesquisadores visitantes.

Os pesquisadores entrevistados se disseram surpresos com o fato de nunca terem visto a série periódica como uma "proxy para a avaliação do desempenho do Ipea". Nesse sentido, entende-se que estudos complementares a esta pesquisa poderão mostrar ao Ipea como criar novos instrumentos para aumentar a sua produção. Assim como a PATD pode ser entendida como um "indicador da produção" do Ipea, será interessante levantarmos outros indicadores de produção que podem auxiliar o instituto a melhorar o seu desempenho. 
Ao se pensar em outras variáveis que podem ser utilizadas para o melhor entendimento do comportamento da variável PATD, levantamos a partir dos dados desta pesquisa, o "número total de pesquisadores autores para cada período".

A tabela abaixo mostra exatamente os valores que esta nova variável, o "número total de autores para cada período", assumiu durante o mesmo período da variável PATD, ou seja, em 37 anos. O gráfico que se segue às tabelas traz os valores desta variável no período:

Tabela 3 - Total de TDs publicados e total de autores por ano

\begin{tabular}{|c|c|c|}
\hline Ano & Total de publicações & Total de autores \\
\hline 1979 & 12 & 15 \\
\hline 1980 & 19 & 21 \\
\hline 1981 & 11 & 13 \\
\hline 1982 & 12 & 19 \\
\hline 1983 & 7 & 14 \\
\hline 1984 & 8 & 11 \\
\hline 1985 & 16 & 24 \\
\hline 1986 & 16 & 28 \\
\hline 1987 & 28 & 48 \\
\hline 1988 & 32 & 49 \\
\hline 1989 & 23 & 33 \\
\hline 1990 & 24 & 33 \\
\hline 1991 & 34 & 49 \\
\hline 1992 & 45 & 88 \\
\hline 1993 & 39 & 84 \\
\hline 1994 & 35 & 68 \\
\hline 1995 & 33 & 52 \\
\hline 1996 & 57 & 108 \\
\hline 1997 & 86 & 165 \\
\hline 1998 & 79 & 158 \\
\hline 1999 & 79 & 169 \\
\hline 2000 & 80 & 164 \\
\hline 2001 & 79 & 163 \\
\hline 2002 & 82 & 172 \\
\hline 2003 & 70 & 151 \\
\hline 2004 & 56 & 115 \\
\hline 2005 & 85 & 192 \\
\hline 2006 & 108 & 242 \\
\hline 2007 & 66 & 169 \\
\hline 2008 & 51 & 98 \\
\hline 2009 & 92 & 214 \\
\hline 2010 & 86 & 178 \\
\hline 2011 & 141 & 298 \\
\hline 2012 & 120 & 225 \\
\hline 2013 & 114 & 212 \\
\hline 2014 & 94 & 184 \\
\hline 2015 & 142 & 266 \\
\hline 2016 & 41 & 88 \\
\hline
\end{tabular}

\begin{tabular}{|c|c|}
\hline Ano & Total de autores \\
\hline 1979 & 15 \\
\hline 1980 & 21 \\
\hline 1981 & 13 \\
\hline 1982 & 19 \\
\hline 1983 & 14 \\
\hline 1984 & 11 \\
\hline 1985 & 24 \\
\hline 1986 & 28 \\
\hline 1987 & 48 \\
\hline 1988 & 49 \\
\hline 1989 & 33 \\
\hline 1990 & 33 \\
\hline 1991 & 49 \\
\hline 1992 & 88 \\
\hline 1993 & 84 \\
\hline 1994 & 68 \\
\hline 1995 & 52 \\
\hline 1996 & 108 \\
\hline 1997 & 165 \\
\hline 1998 & 158 \\
\hline 1999 & 169 \\
\hline 2000 & 164 \\
\hline 2001 & 163 \\
\hline 2002 & 172 \\
\hline 2003 & 151 \\
\hline 2004 & 115 \\
\hline 2005 & 192 \\
\hline 2006 & 242 \\
\hline 2007 & 169 \\
\hline 2008 & 98 \\
\hline 2009 & 214 \\
\hline 2010 & 178 \\
\hline 2011 & 298 \\
\hline 2012 & 225 \\
\hline 2013 & 212 \\
\hline 2014 & 184 \\
\hline 2015 & 266 \\
\hline 2016 & 88 \\
\hline Total & 4380 \\
\hline 5 & \\
\hline & \\
\hline
\end{tabular}

Nota: Tabela elaborada e dados trabalhados pela autora. 
O estudo da correlação entre essas variáveis torna-se possível a partir da coleta e organização dos dados. O valor encontrado para a correlação entre y (PATD) e x (Número de pesquisadores autores) foi de 0,987801308. Como visto, existe um alto grau de correlação entre essas duas variáveis. Ou seja, entre a Produção Anual de Textos para Discussão do Ipea (PATD) e o "número total de pesquisadores autores para cada período". Na análise dos valores encontrados para a correlação, podemos considerar que 0.9, para mais ou para menos, indica uma correlação muito forte. O gráfico abaixo mostra o comportamento das duas variáveis observadas ao longo dos últimos 37 anos.

Gráfico 4 - Total de Publicações de TDs e Total de Pesquisadores Autores - (1979 a 2015)

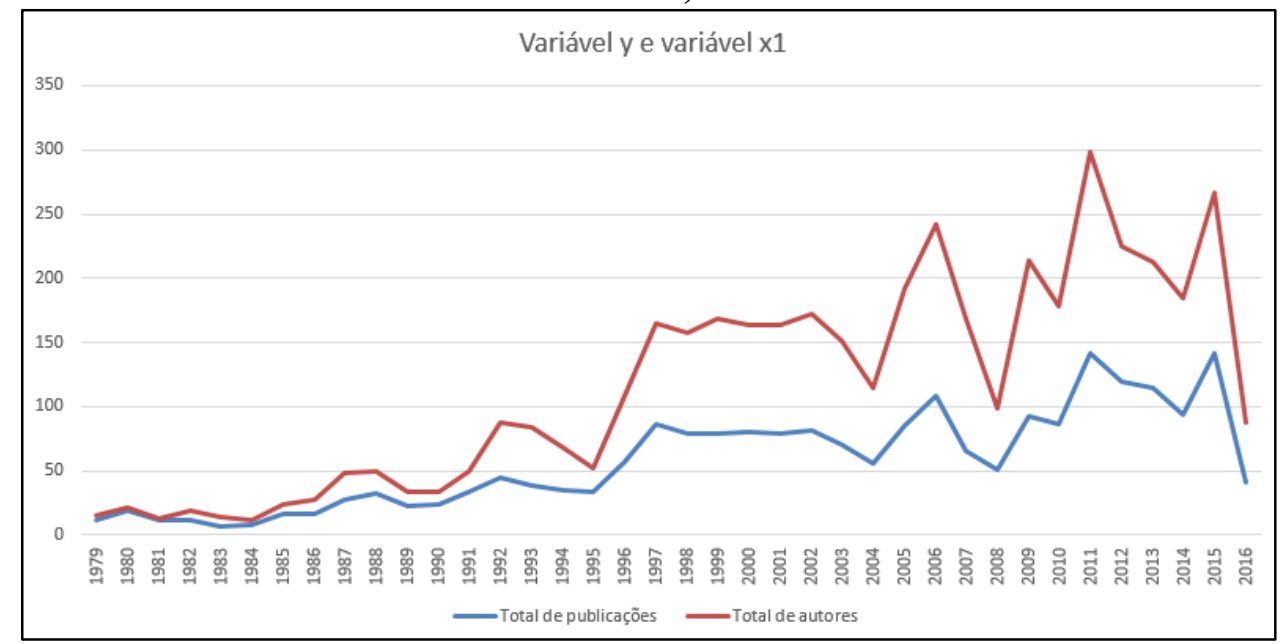

Nota: Elaboração da autora. 
Ao considerar as médias de autores por TDs publicados, têm-se então os seguintes valores:

Tabela 4 - Média de Autores por TDs publicados e total de autores por ano

\begin{tabular}{|c|c|c|c|}
\hline Ano & Total de autores por ano & Media de autores por TD & Total de publicações \\
\hline 1979 & 15 & 1,25 & 12 \\
\hline 1980 & 21 & 1,1 & 19 \\
\hline 1981 & 13 & 1,18 & 11 \\
\hline 1982 & 19 & 1,58 & 12 \\
\hline 1983 & 14 & 2 & 7 \\
\hline 1984 & 11 & 1,37 & 8 \\
\hline 1985 & 24 & 1,5 & 16 \\
\hline 1986 & 28 & 1,75 & 16 \\
\hline 1987 & 48 & 1,71 & 28 \\
\hline 1988 & 49 & 1,53 & 32 \\
\hline 1989 & 33 & 1,43 & 23 \\
\hline 1990 & 33 & 1,37 & 24 \\
\hline 1991 & 49 & 1,44 & 34 \\
\hline 1992 & 88 & 1,95 & 45 \\
\hline 1993 & 84 & 2,15 & 39 \\
\hline 1994 & 68 & 1,94 & 35 \\
\hline 1995 & 52 & 1,57 & 33 \\
\hline 1996 & 108 & 1,89 & 57 \\
\hline 1997 & 165 & 1,91 & 86 \\
\hline 1998 & 158 & 2 & 79 \\
\hline 1999 & 169 & 2,13 & 79 \\
\hline 2000 & 164 & 2,05 & 80 \\
\hline 2001 & 163 & 2,06 & 79 \\
\hline 2002 & 172 & 2,09 & 82 \\
\hline 2003 & 151 & 2,15 & 70 \\
\hline 2004 & 115 & 2,05 & 56 \\
\hline 2005 & 192 & 2,25 & 85 \\
\hline 2006 & 242 & 2,24 & 108 \\
\hline 2007 & 169 & 2,56 & 66 \\
\hline 2008 & 98 & 1,92 & 51 \\
\hline 2009 & 214 & 2,32 & 92 \\
\hline 2010 & 178 & 2,06 & 86 \\
\hline 2011 & 298 & 2,11 & 141 \\
\hline 2012 & 225 & 1,87 & 120 \\
\hline 2013 & 212 & 1,85 & 114 \\
\hline 2014 & 184 & 1,95 & 94 \\
\hline 2015 & 266 & 1,87 & 142 \\
\hline 2016 & 88 & 2,14 & 41 \\
\hline
\end{tabular}

Nota: Tabela elaborada pela autora.

A tabela 4 mostra as médias do número de autores por TD publicado em todo o período. Pode-se observar que houve um aumento no número médio de autores por TD publicado ao longo do período. A menor média observada foi de 1,1, observada em 1980. A maior média observada foi de 2,56, observada em 2007. 
Gráfico 5 - Média de Autores por TD a Cada Ano - (1979 a 2015)

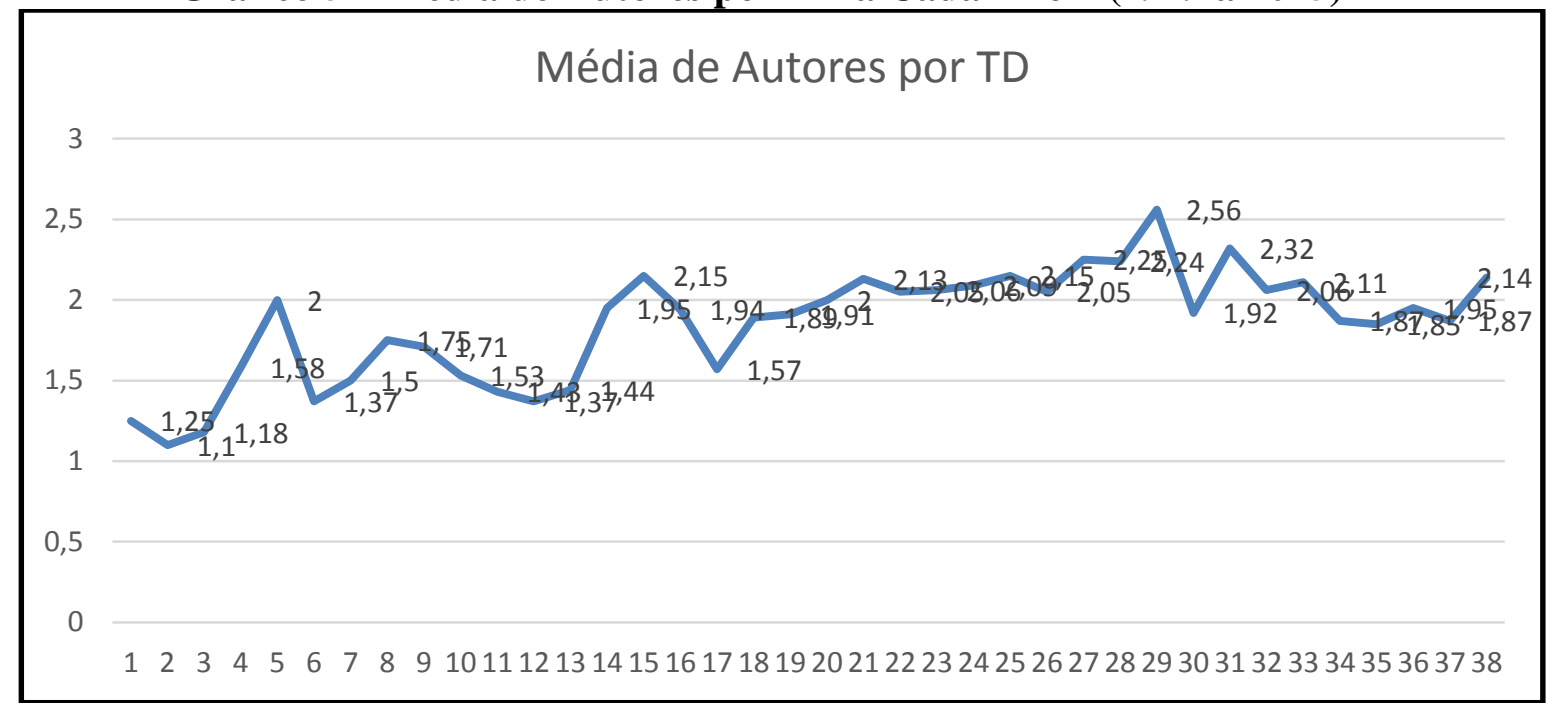

Nota: Elaboração da autora.

Observa-se, a partir destes dados, a tendência de multiautoria para os Textos para Discussão (TD) do Ipea, observada por Hudson (1996) em várias áreas do conhecimento. 


\subsection{Resultados: análise quantitativa por períodos de gestão}

Apresenta-se a seguir os dados quantitativos da série periódica TD do Ipea por período de gestão. O objetivo é mostrar o desempenho do Ipea a partir dos períodos de gestão correspondentes. O registro destes dados poderá auxiliar o Ipea a entender o seu desempenho nos diferentes períodos de gestão da história do instituto. Ressaltamos que a análise se restringe a série TD e não compreende outros indicadores de produção do Ipea que por ventura possam ser observados.

A tabela abaixo relaciona, em ordem crescente, os dados correspondentes ao total de publicações da série TD do Ipea, coletados de 1979 a 01/07/2016.

Tabela 5 - Total de Publicações por Presidentes do Brasil

\begin{tabular}{|l|c|}
\hline \multicolumn{1}{|c|}{ Presidente do Brasil } & Total de publicações \\
\hline João Batista de Oliveira Figueiredo (1979-1984) & 69 \\
\hline José Sarney (1985-1989) & 115 \\
\hline Fernando Collor de Mello (1990-1992) & 103 \\
\hline Itamar Franco (1993-1994) & 74 \\
\hline Fernando Henrique Cardoso (1995-2002) & 575 \\
\hline Luiz Inácio Lula da Silva (2003-2010) & 614 \\
\hline Dilma Roussef (2011-2016) & 657 \\
\hline
\end{tabular}

Nota: Tabela elaborada pela autora.

O gráfico 6 traz o destacado desempenho do Ipea nos períodos de gestão de compreendidos entre 1995 e 2016, ou seja, nos últimos 21 anos. Se considerarmos os números absolutos registrados para a série periódica, podemos verificar que, de alguma forma, nos períodos de gestão de FHC, Lula e Dilma o Ipea alcançou patamares de produção muito acima dos períodos anteriores.

Gráfico 6 - Total de Publicação de TD por Presidentes do Brasil - (1979 a 2015)

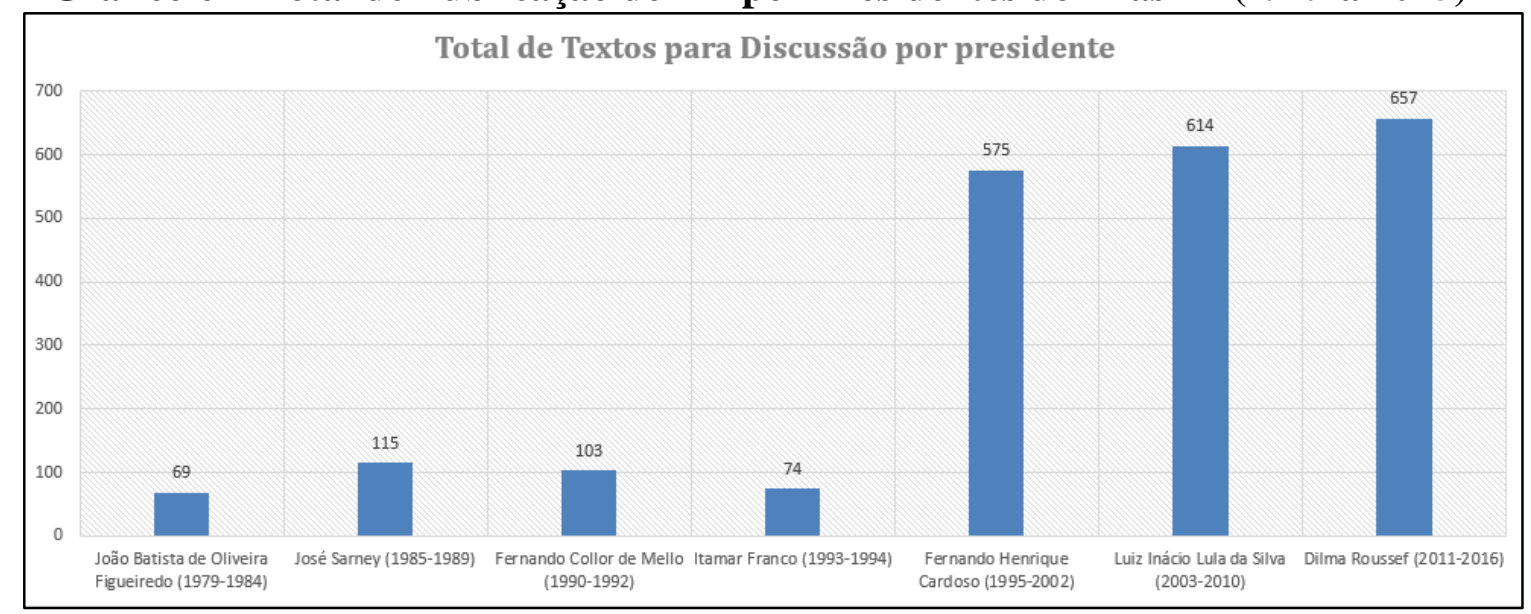

Nota: Elaboração da autora.

Em números absolutos registrados para a série periódica, pode-se verificar que nos períodos de gestão de FHC, Lula e Dilma (1995-2015), o Ipea produziu o equivalente a $84 \%$ de toda a sua produção publicada por meio da série TD. Verifica-se que os três 
presidentes conseguiram do Ipea um desempenho espetacular no que diz respeito a produção de estudos e pesquisas.

Destaca-se o desempenho do Ipea durante o período de gestão de Dilma Rousseff, compreendido entre 2011 e 2015. Enquanto FHC e Lula, que estiveram no poder por 8 anos cada, foram responsáveis pela produção de $26 \%$ e $28 \%$ da produção total do Ipea publicada em TD, respectivamente; Dilma, que permaneceu na presidência da república por 5 anos, teve em seu período de gestão o registro do melhor desempenho do Ipea nos últimos 37 anos. A produção total do Ipea no período de gestão de Dilma correspondeu a $30 \%$ de toda a produção do instituto.

A tabela 5 traz as médias calculadas para o período de gestão de cada um dos presidentes do Brasil nos 37 anos da série:

Tabela 6 - Média de TDs por ano de mandato
\begin{tabular}{|l|r|}
\hline Presidente & Media de TDs por ano de mandato \\
\hline Dilma & 109,5 \\
\hline Lula & 76,75 \\
\hline FHC & 71,875 \\
\hline Itamar & 24,66 \\
\hline Collor & 34,33 \\
\hline Sarney & 23 \\
\hline Figueiredo & 11,5 \\
\hline
\end{tabular}

Nota: Tabela elaborada pela autora.

Chama a atenção o desempenho do Ipea nos períodos de gestão de FHC e Lula, onde a média de TDs produzidos foi de 71,8 e 76,7, respectivamente. O desempenho do Ipea no período de gestão de Dilma Rousseff, que em números absolutos já chamava a atenção, mostra-se de fato superior, tendo alcançado em valores médios, 109,5 TD publicados por ano de gestão.

Como foi observado, houve um aumento considerável na quantidade de trabalhos publicados pelo Ipea nos últimos 20 anos. Nesse contexto sabemos que existem uma série de estudos que observam uma "tendência mundial de aumento observada na produção científica" em várias áreas do conhecimento. (KING, 2004). A análise quantitativa da série periódica mostra esse aumento na produção de estudos e pesquisas no Ipea. Como visto, nos três últimos períodos de gestão federal (1995-2015), o Ipea produziu o equivalente a $84 \%$ de toda a sua produção publicada por meio da série Texto para Discussão (TD). Nos primeiros 16 anos observados, o Ipea produziu o equivalente a $16 \%$.

O resultado da análise da produtividade do Ipea, com base no "indicador de produção" ou da variável de produção que chamamos "PATD", a partir da análise da série temporal, mostra um desempenho crescente nos últimos 20 anos. O estudo de outras variáveis que se relacionam com PATD nesses 37 anos da série poderá auxiliar o órgão em relação às tomadas de decisão relativas ao aumento da produtividade, justamente para reagir as sucessivas quedas de produção observadas logo após os picos de produção registrados. 


\subsection{Resultados: análise quantitativa por períodos de gestão interna}

Apresenta-se a seguir a produção do Ipea organizada a partir da gestão interna de seus presidentes. A partir dos números totais registrados, observa-se que em dois períodos de gestão, o de Roberto Borges Martins e o de Márcio Porchmann, o Ipea registrou um desempenho de destaque. Na gestão destes, foram produzidos 314 e 441 trabalhos, respectivamente. Mas, ao considerar as médias por período de gestão, será que esses dois gestores obtiveram um desempenho superior ao de outros presidentes do Ipea?

Nesse sentido, foram reunidos na tabela 6 os dados relativos aos períodos de gestão de cada presidente do Ipea, para o período analisado, de 1979 a 2016. Incluiu-se os registros de 2016 para que os períodos de gestão mais recentes pudessem ser inseridos nesta análise.

Tabela 7 -Média de produção de TDs por Períodos de Gestão dos Presidentes do Ipea

\begin{tabular}{|c|c|c|c|c|c|}
\hline Presidente $\mathrm{n}$ - & Presidente do Ipea & Periodo de Gestão & $\begin{array}{c}\text { Periodo de gestão em } \\
\text { meses }\end{array}$ & Total de TD & $\begin{array}{c}\text { Média por } \\
\text { mês de } \\
\text { gestão }\end{array}$ \\
\hline 60 & Marcos Amorim Neto & 15/03/1979 a 15/08/1979 & 5 meses & 9 & 1,8 \\
\hline 70 & José Flávio Pécora & $15 / 08 / 1979$ a $14 / 03 / 1985$ & 66 meses & 67 & 1,01 \\
\hline 80 & Andrea Sandro Calabi & $18 / 03 / 1985$ a $12 / 03 / 1986$ & 11 meses & 12 & 1,09 \\
\hline 90 & Henri Philippe Reichstul & $12 / 03 / 1986$ a $15 / 04 / 1987$ & 13 meses & 22 & 1,69 \\
\hline 100 & Michal Gartenkraut & $29 / 04 / 1987$ a $25 / 01 / 1988$ & 9 meses & 22 & 2,44 \\
\hline 110 & Ricardo Luís Santiago & 01/02/1988 a 01/03/1990 & 24 meses & 57 & 2,37 \\
\hline $12 \underline{0}$ & Antônio kandir & 05/04/1990 a 13/05/1991 & 13 meses & 28 & 2,15 \\
\hline $13 \underline{0}$ & Roberto Brás Matos Macêdo & 23/05/1991 a 03/10/1992 & 17 meses & 63 & 3,7 \\
\hline 140 & Líscio Fábio de Brasil Camargo & 10/11/1992 a 04/03/1993 & 4 meses & 16 & 4 \\
\hline 150 & Antônio Nilson Craveiro Holanda & 01/04/1993 a 08/06/1993 & 2 meses & 10 & 5 \\
\hline 160 & Aspasia Brasileiro A. de Camargo & 09/06/1993 a 01/01/1995 & 18 meses & 55 & 3,05 \\
\hline $17 \underline{0}$ & Andrea Sandro Calabi & 11/01/1995 a 09/02/1996 & 13 meses & 43 & 3,3 \\
\hline $18^{\circ}$ & Fernando Antônio Rezende da Silva & 09/02/1996 a 18/01/1999 & 35 meses & 218 & 6,22 \\
\hline $19^{\circ}$ & Roberto Borges Martins & 18/01/1999 a 01/01/2003 & 47 meses & 314 & 6,68 \\
\hline 200 & Glauco Antonio Truzzi Arbix & 05/03/2003 a $22 / 05 / 2006$ & 38 meses & 254 & 6,68 \\
\hline 210 & Luiz Henrique Proença Soares & $22 / 05 / 2006$ a $13 / 08 / 2007$ & 14 meses & 114 & 8,14 \\
\hline $22^{\circ}$ & Marcio Porchmann & $14 / 08 / 2007$ a $04 / 06 / 2012$ & 58 meses & 441 & 7,6 \\
\hline 230 & Vanessa Petrelli Corrêa & 05/06/2012 a 11/09/2012 & 3 meses & 26 & 8,66 \\
\hline 240 & Marcelo Cortes Neri & $12 / 09 / 2012$ a 05/05/2014 & 20 meses & 201 & 10,05 \\
\hline 250 & Sergei Suarez Dillon Soares & $21 / 05 / 2014$ a 01/04/2015 & 11 meses & 99 & 9 \\
\hline $26 \underline{0}$ & Jesse Jose Freire de Souza & 02/04/2015 a $18 / 05 / 2016$ & 13 meses & 126 & 9,69 \\
\hline $27 \underline{0}$ & Manoel Carlos de Castro Pires & $18 / 05 / 2016$ a 01/06/2016 & 0 meses & 0 & 0 \\
\hline 280 & Ernesto Lozardo & 01/06/2016 a 31/06/2016 & 01 meses & 5 & 5 \\
\hline
\end{tabular}

Nota: Tabela elaborada pela autora.

Verifica-se dois distintos patamares relativos à produção de TDs do Ipea. O primeiro que vai de 1979 a 1994, e um segundo que vai de 1995 a 2015. Observa-se que, a partir do governo de FHC, seguido pelos governos de Lula e Dilma, o Ipea entrou em um ritmo diferenciado de produção. Se há uma relação entre o número de TDs publicados e a estabilidade político-institucional estabelecida por esses governos democráticos, não podemos afirmar, mas há indícios de que a estabilidade político-institucional tenha propiciado o aumento da produção do Ipea no que diz respeito aos resultados de estudos e pesquisas.

A estabilidade político-institucional, foi apontada pelo pesquisador Luiz Cesar Loureiro de Azeredo como um dos fatores responsáveis por essa mudança de patamar na produção. Outra questão apontada pelo pesquisador entrevistado, e que deve ser considerada, tem 
relação com a mudança no posicionamento institucional do Ipea, ocorrida a partir de 1986. O Ipea, além de atuar no planejamento governamental, passa a ter a pesquisa como uma das suas principais competências institucionais.

A tabela 6 apresenta as médias de produção mensais para cada período de gestão. Como podemos verificar, a média passou de 1.01, a menor média registrada em todo o período, para 10,05, a maior média registrada em toda história da série temporal.

Observa-se que na gestão de Fernando Antônio Resende da Silva, a média sobe de 3,3 para 6,22. Seus dois sucessores, Roberto Borges Martins e Glauco Arbix, mantém a média na casa de 6,68. A gestão de Luiz Henrique Proença Soares registrou então uma média de produção de 8,14 TDs por mês de gestão, primeira média acima de 7,0 e 8,0 para todo o período.

A gestão de Márcio Porchmann registrou uma média de 7,6 TDs por mês de gestão, valor abaixo de seu antecessor e de seu sucessor, que registraram, respectivamente, as médias mensais de 8,14 e 8,66. Como visto, os períodos de gestão seguintes registram as maiores médias de produção mensal para todo o período. Destaca-se o período de gestão de Marcelo Cortes Neri, que registrou a média mensal de 10,05 TDs, a maior média de produção mensal observada. Após o período de gestão de Neri, foram registradas as duas outras grandes médias para todo o período, 9,0 e 9,69, que correspondem a produção mensal relativa às gestões de Sergei Suarez Dillon Soares e Jesse de Souza, respectivamente. 


\subsection{Resultados: análise quantitativa por área temática}

Os trabalhos que analisaram a questão temática da série periódica TDs, o TD 1000 (2004) e o TD 2000 (2014), o fizeram em profundidade; no entanto, não apresentaram uma exposição gráfica quantitativa e cronológica da produção do Ipea no que se refere a classificação temática dos estudos e pesquisas.

A análise da temática da série objetiva apresentar gráficos quantitativos por áreas temáticas. O quadro abaixo traz o resumo do Estudo do Domínio da série periódica Texto para Discussão (TD) do Ipea, com base no "Journal of Economic Literature Classification System (JELCS)". Ao todo foram classificados $\mathbf{2 . 2 0 3}$ Textos para Discussão (TD). A última coleta de dados para esta análise foi realizada no dia 01/07/2016.

Tabela 8 - Total de TDs por Categoria JEL e Percentual de TDs por Categoria JEL

\begin{tabular}{|c|c|c|}
\hline Categorias & Totais por categoria JEL & \% por categoria JEL \\
\hline (A) Economia Geral e Ensino & 1 & 0,04 \\
\hline (B) História do Pensamento Econômico, Metodologia e Abordagens Heterodoxas & 4 & 0,18 \\
\hline (C) Matemática e Métodos Quantitativos & 17 & 0,77 \\
\hline (D) Microeconomia & 62 & 2,81 \\
\hline (E) Macroeconomia e Economia Monetária & 356 & 16,15 \\
\hline (F) Economia Internacional & 169 & 7,67 \\
\hline (G) Economia Financeira & 21 & 0,95 \\
\hline (H) Economia Pública & 491 & 22,28 \\
\hline (I) Saúde, Educação e Bem-Estar & 281 & 12,75 \\
\hline (J) Trabalho e economia demográfica & 195 & 8,85 \\
\hline (K) Direito e Economia & 15 & 0,68 \\
\hline (L) Organização Industrial & 97 & 4,4 \\
\hline (M) Administração de Empresas e Economia Empresarial; Marketing; Contabilidade & 22 & 0,99 \\
\hline (N) História Econômica & 20 & 0,9 \\
\hline (O) Desenvolvimento Económico, Mudança Tecnológica e Crescimento & 78 & 3,54 \\
\hline (P) Sistemas Econômicos & 1 & 0,04 \\
\hline (Q) Agrícola e Economia De Recursos Naturais & 183 & 8,3 \\
\hline (R) Urbano, Rural e Economia Regional & 177 & 8,03 \\
\hline (Y) Categorias Variadas & 2 & 0,09 \\
\hline (Z) Outros Tópicos Especiais & 11 & 0,49 \\
\hline Total & 2.203 & \\
\hline
\end{tabular}

Nota: Tabela elaborada pela autora.

Para a organização dos dados, escolheu-se elaborar os gráficos por período de gestão, apesar de se ter elaborado um gráfico temático para cada um dos 37 anos da série periódica. Identificou-se os temas que mais estiveram presentes nos trabalhos publicados em forma de Textos para Discussão (TD) do Ipea para todo o período.

A tabela 8 traz os dados resultantes de toda análise quantitativa da série periódica, realizada em função da classificação temática, de cada um dos TDs que compuseram a amostra. O Estudo do Domínio ou a Cobertura Temática da série periódica "Texto para Discussão (TD)" do Ipea mostrou quais as áreas temáticas tiveram o maior número de estudos e pesquisas realizadas.

As três áreas que registraram o maior número de estudos e pesquisas foram: 1) Economia Pública, com 491 TDs; 2) Macroeconomia e Economia Monetária, com 356 TDs; e 3) Saúde, Educação e Bem-Estar, com $\mathbf{2 8 1}$ TDs publicados. 
A seguir apresenta-se os gráficos temáticos elaborados por períodos de gestão. Considere os períodos da tabela 5 para na análise da cobertura temática da série.

Os gráficos 7 e 8 reúnem os dados quantitativos, de acordo com a classificação temática atribuída a cada um dos TDs, nos períodos de gestão de João Batista de Oliveira Figueiredo (1979-1984) e José Sarney (1985-1989). A maioria dos TDs publicados nestes dois períodos foram classificados na categoria "Macroeconomia e Economia monetária". Sabe-se que tais períodos foram marcados por problemas de inflação e dívida.

Gráfico 7 - Classificação Temática dos TDs no Período Figueiredo

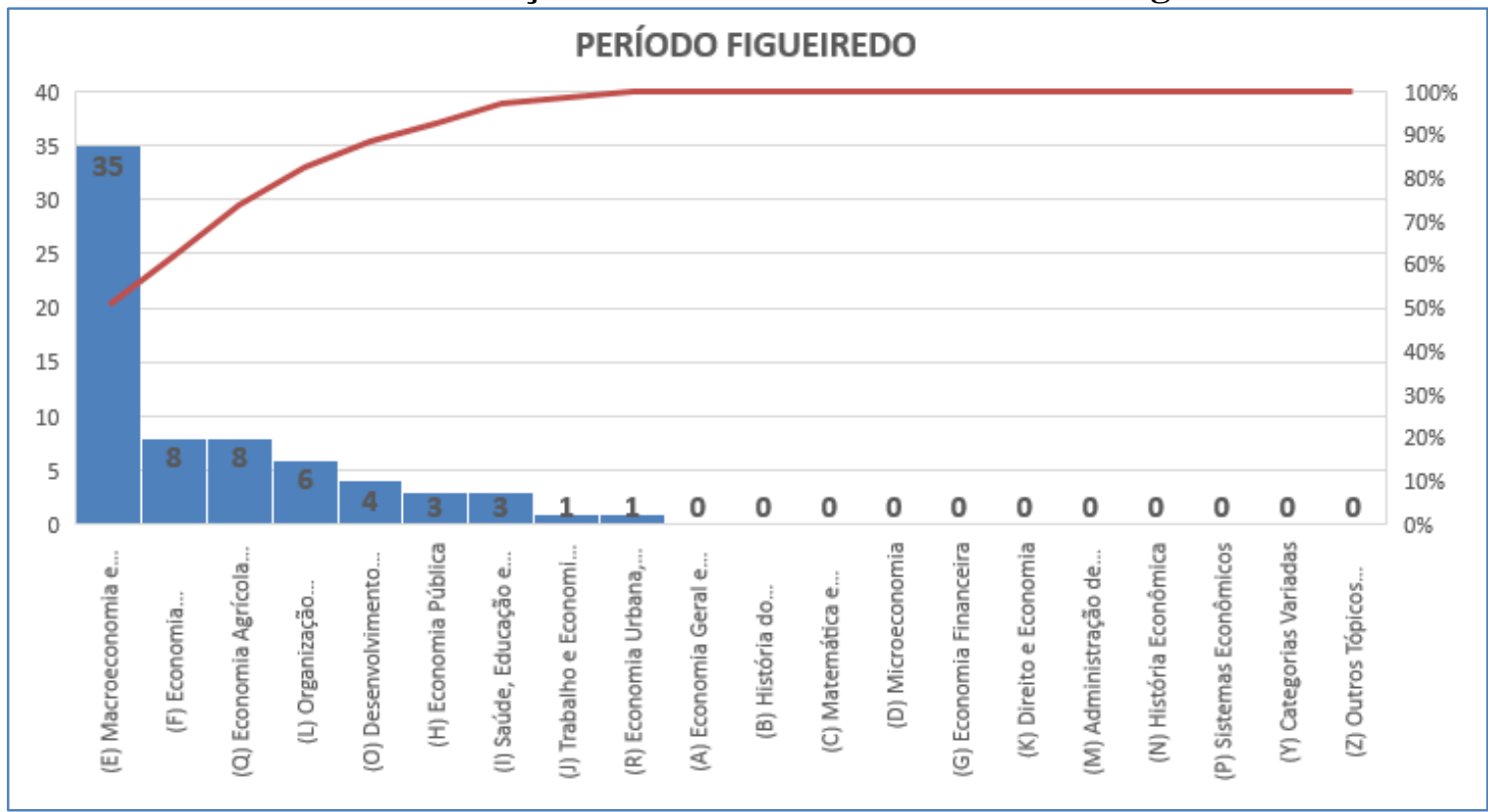

Nota: Elaboração da autora.

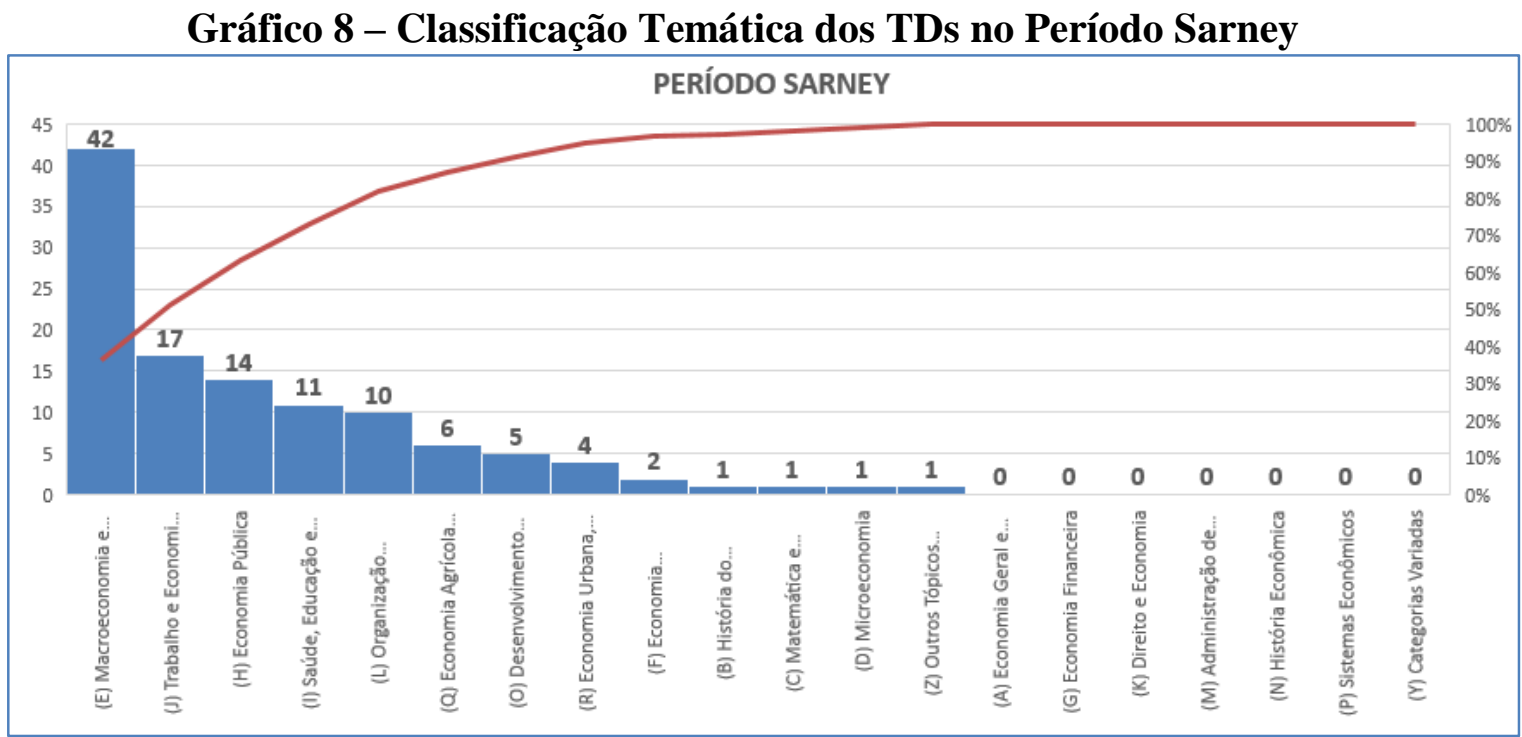

Nota: Elaboração da autora. 
Os gráficos 9 e 10 reúnem os dados quantitativos, de acordo com a classificação temática atribuída a cada um dos TDs, nos períodos de gestão de Fernando Collor de Mello (19901992) e Itamar Franco (1993-1994). A maioria dos TDs publicados nestes dois períodos foram classificados na categoria "Saúde, Educação e Bem-Estar". Observou-se uma clara mudança no foco das pesquisas. Resolve-se o problema da inflação e, a partir de então, abre-se espaço para discutir outras questões.

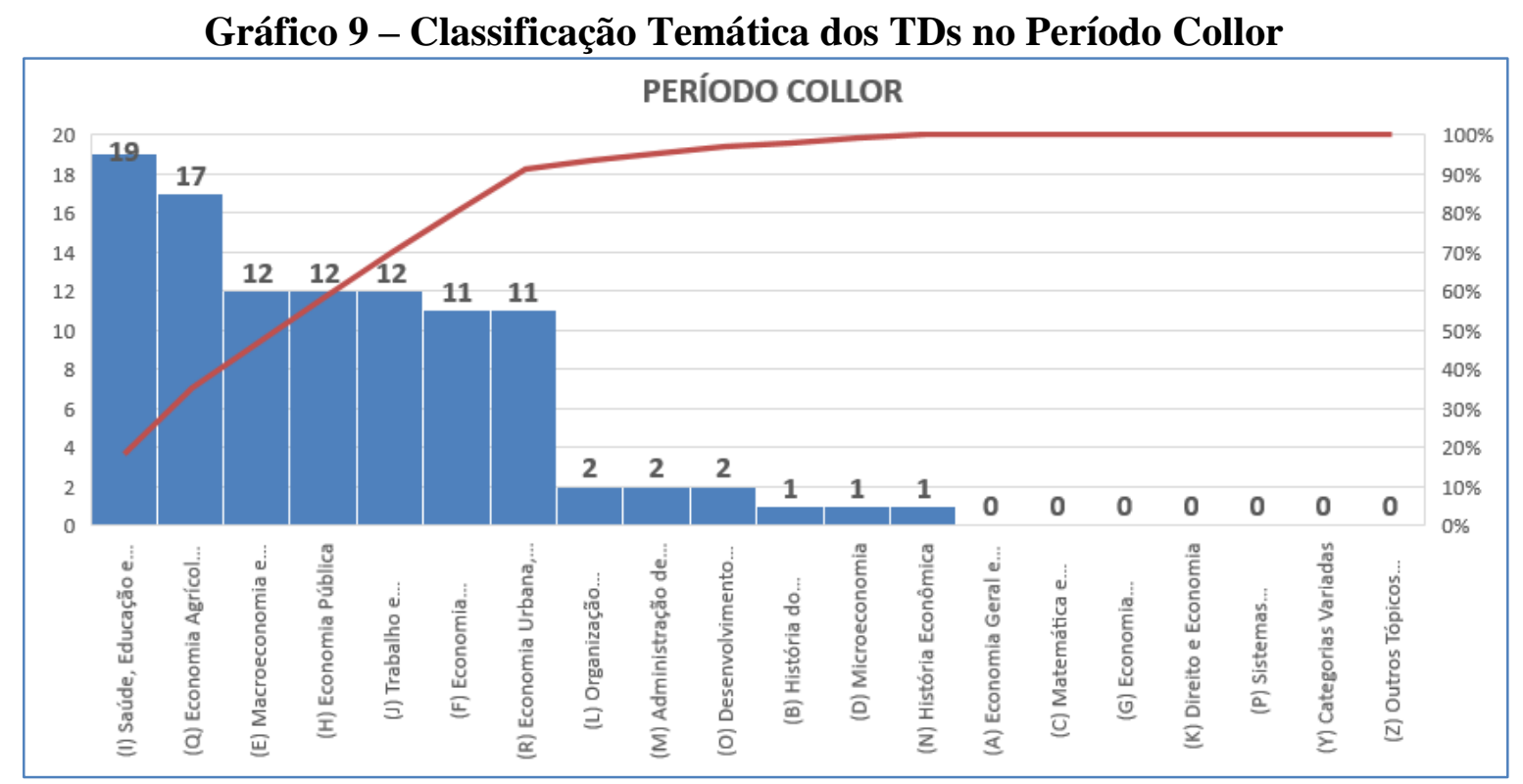

Nota: Elaboração da autora.

Gráfico 10 - Classificação Temática dos TDs no Período Itamar

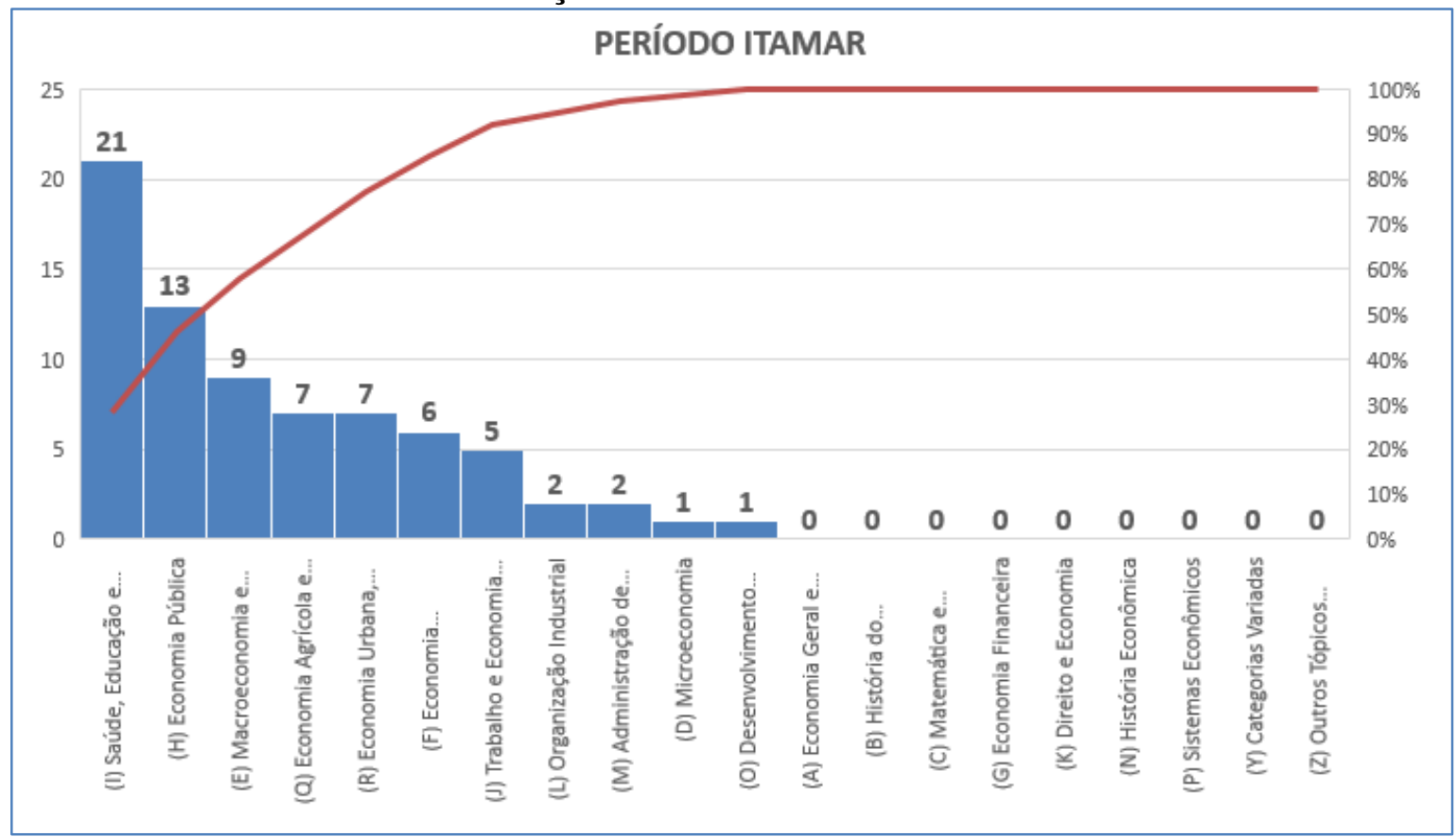

Nota: Elaboração da autora. 
Os gráficos 11, 12 e 13 reúnem os dados quantitativos, de acordo com a classificação temática atribuída a cada um dos TDs, nos períodos de gestão de Fernando Henrique Cardoso (1995-2002), Luiz Inácio Lula da Silva (2003-2010) e Dilma Rousseff (20112016).

A maioria dos TDs publicados no período de FHC foram classificados nas categorias "Saúde, Educação e Bem-Estar" e "Economia Pública". Estes dois temas também foram os mais pesquisados no período de gestão de Lula, no entanto, em ordem inversa, onde a maioria dos TDs publicados foram classificados na categoria "Economia Pública", seguidos pela categoria "Saúde, Educação e Bem-Estar".

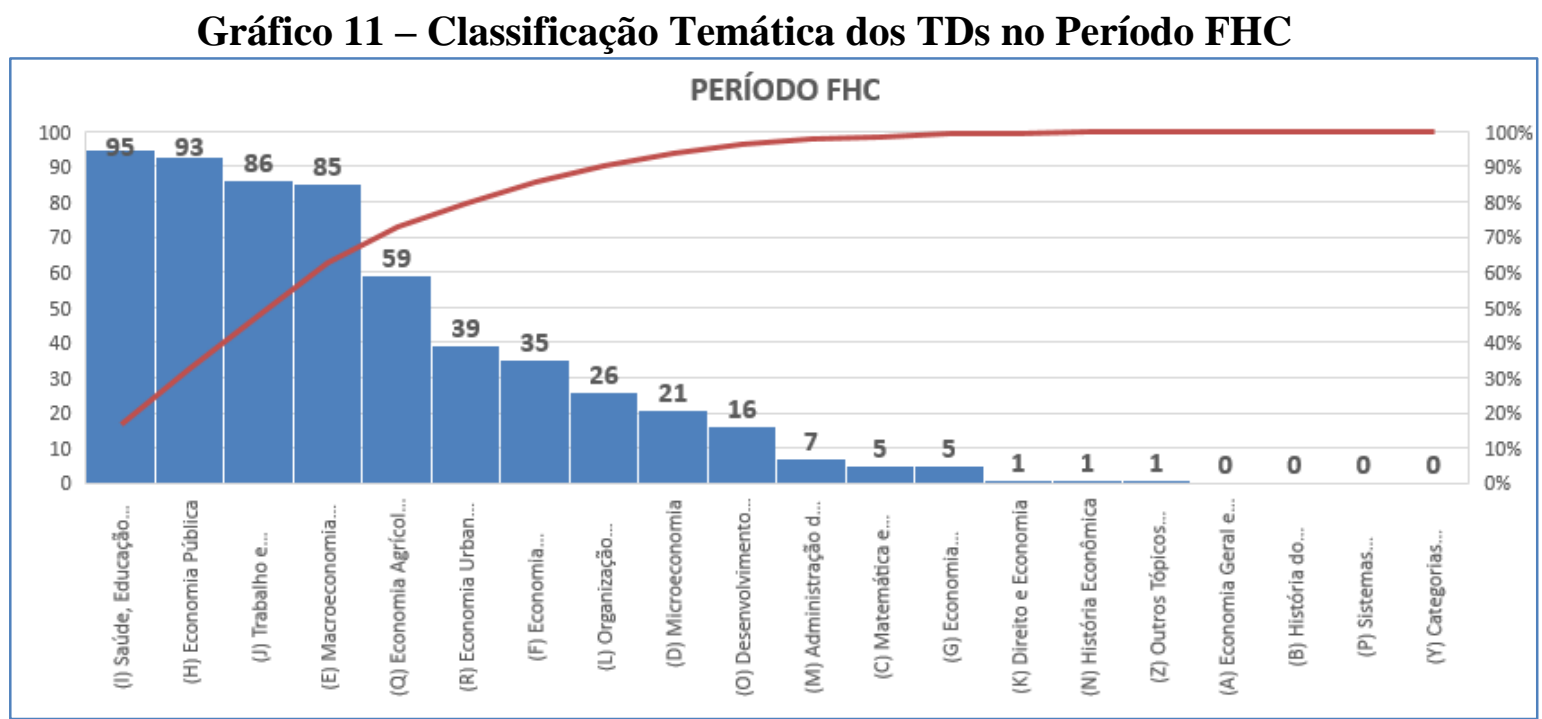

Nota: Elaboração da autora.

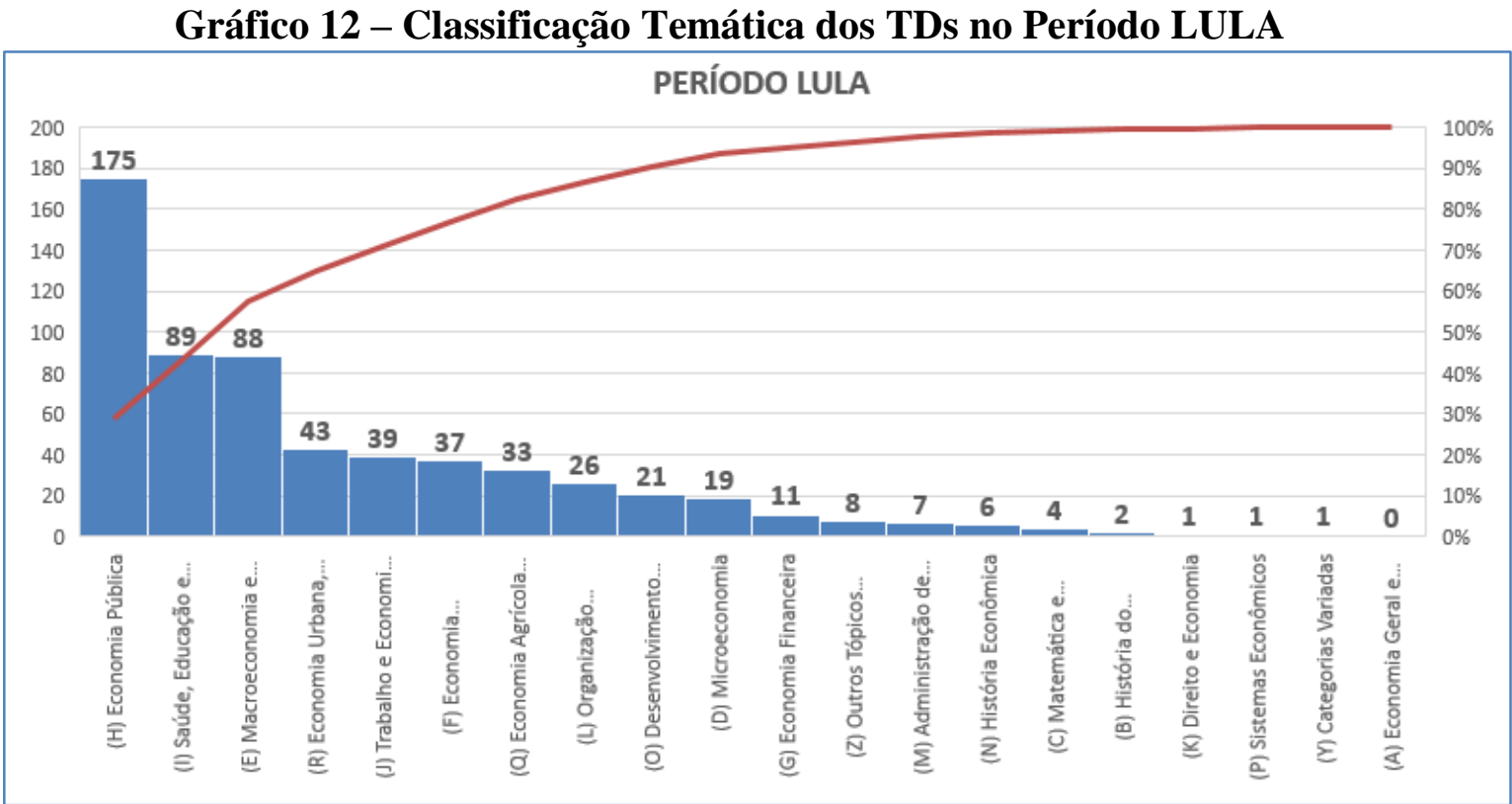

Nota: Elaboração da autora. 
Verifica-se no gráfico 13, período de gestão de Dilma Rousseff, a maioria dos TDs publicados foram classificados nas categorias "Economia Pública" e "Macroeconomia e Economia monetária". Como visto, os resultados mostram-se alinhados com a volta dos problemas macroeconômicos.

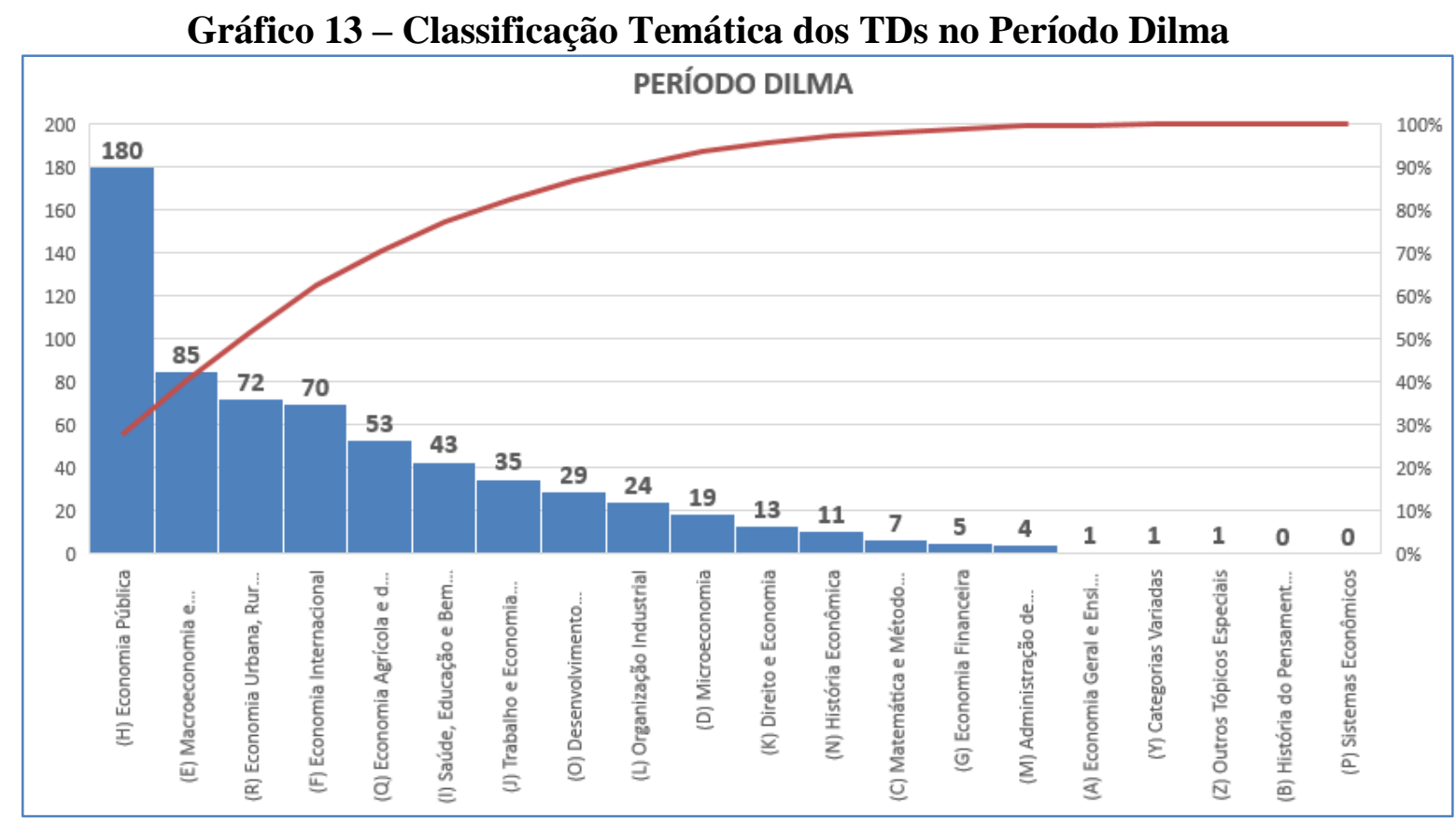

Nota: Elaboração da autora. 


\subsection{Resultados: análise quantitativa por tipo de autoria}

Verificou-se também como o Ipea publicou seus trabalhos no que se refere a autoria dos trabalhos. Objetivou-se mostrar, a partir da análise de autoria, por exemplo, dados quantitativos da série sobre multiautoria ou coautoria e autoria única. A análise de autoria nos ajudou a começar a entender como os autores se comportaram no que diz respeito às diversas redes de pesquisa que se formaram a partir das parcerias estabelecidas ao longo de anos de atividade de pesquisa. Para tanto, lançamos mão da já consagrada análise de coautoria, que fornece dados considerados duros se comparados aos dados de citação.

A análise de coautoria possui essa característica de fornecer dados confiáveis para a Análise de Redes Sociais (ARS), pois não existem dúvidas sobre as relações estabelecidas quando dois ou mais autores se juntam para escrever um artigo resultante de estudos ou pesquisas. A série periódica Texto para Discussão (TD) do Ipea, nosso objeto de estudo, ofereceu um desafio no que diz respeito a quantidade de dados analisados, pois além de ser uma série de 37 anos, as relações de coautoria estabelecidas e os dados derivados desta análise formaram um conjunto grande de dados para análise de redes sociais. Foram considerados nesta análise quantitativa, todos os 2.203 fascículos publicados pela série periódica de 1979 a maio de 2016.

Apenas 03 títulos foram publicados sem autoria pessoal definida, tendo estes a responsabilidade da autoria atribuída à entidade, ou seja, em nome do Instituto de Pesquisa Econômica Aplicada (Ipea). Isso demonstra o total respeito do instituto a seus pesquisadores e colaboradores, que preserva a atribuição da autoria pessoal e concede a titularidade dos diretos morais dos trabalhos aos seus verdadeiros criadores intelectuais.

Como foi possível observar, tal titularidade é concedida inclusive aos diversos autores externos que publicaram trabalhos pelo Ipea, sejam professores e pesquisadores integrantes dos quadros das instituições de pesquisa e ensino superior, de universidades públicas e privadas; sejam servidores públicos integrantes de outros órgãos da Administração Pública Brasileira ou mesmo estudantes de graduação e pós-graduação, bolsistas de pesquisa do próprio Ipea.

Apresentamos na Tabela 9 o resultado da classificação dos TDs conforme o tipo de autoria adotado. O resultado nos mostra que: 963 títulos foram publicados em Autoria única ( 1 autor); em coautoria ( 2 autores) foram publicados 696 títulos e em multiautoria (3 ou mais autores), 540 trabalhos. Apenas 03 títulos foram publicados sem autoria pessoal definida, tendo estes a responsabilidade da autoria atribuída à entidade.

Tabela 9 - Total de TDs por Tipo de Autoria

\begin{tabular}{|l|r|}
\hline \multicolumn{1}{|c|}{ Tipo de Autoria } & Total de TDs \\
\hline Autoria única & 963 \\
\hline Coautoria & 696 \\
\hline Multiautoria & 540 \\
\hline Autoria Entidade & 3 \\
\hline \multicolumn{2}{|l|}{ Nota: Tabela elaborada pela autora. }
\end{tabular}

Nota: Tabela elaborada pela autora. 
Os dados quantitativos que se reuniu no Gráfico 14, mostra que os autores, que publicaram trabalhos na série periódica TD do Ipea, estabeleceram diferentes formas de autoria para a publicação de estudos e pesquisas.

Verificou-se que, foram publicados trabalhos elaborados por um único autor em 963 fascículos. Estudar a autoria única é muito relevante do ponto de vista da Comunicação Científica, pois, a partir destes dados, podemos confirmar ou não uma tendência observada na literatura científica mundial, em diversas áreas do conhecimento, quanto à tendência de redução do número de trabalhos em autoria única.

Além disso, do ponto de vista da ARS, essa característica de trabalhar "isoladamente" terá reflexos na participação destes "sujeitos isolados" na Rede de pesquisa. Sujeitos isolados tendem a ter um número menor de laços relacionais, isso pode os levar a não ocuparem lugares estratégicos na Rede de pesquisa. Atores que publicam exclusivamente de forma isolada se diferenciam daqueles que publicam sozinhos, mas publicam também em coautoria e multiautoria.

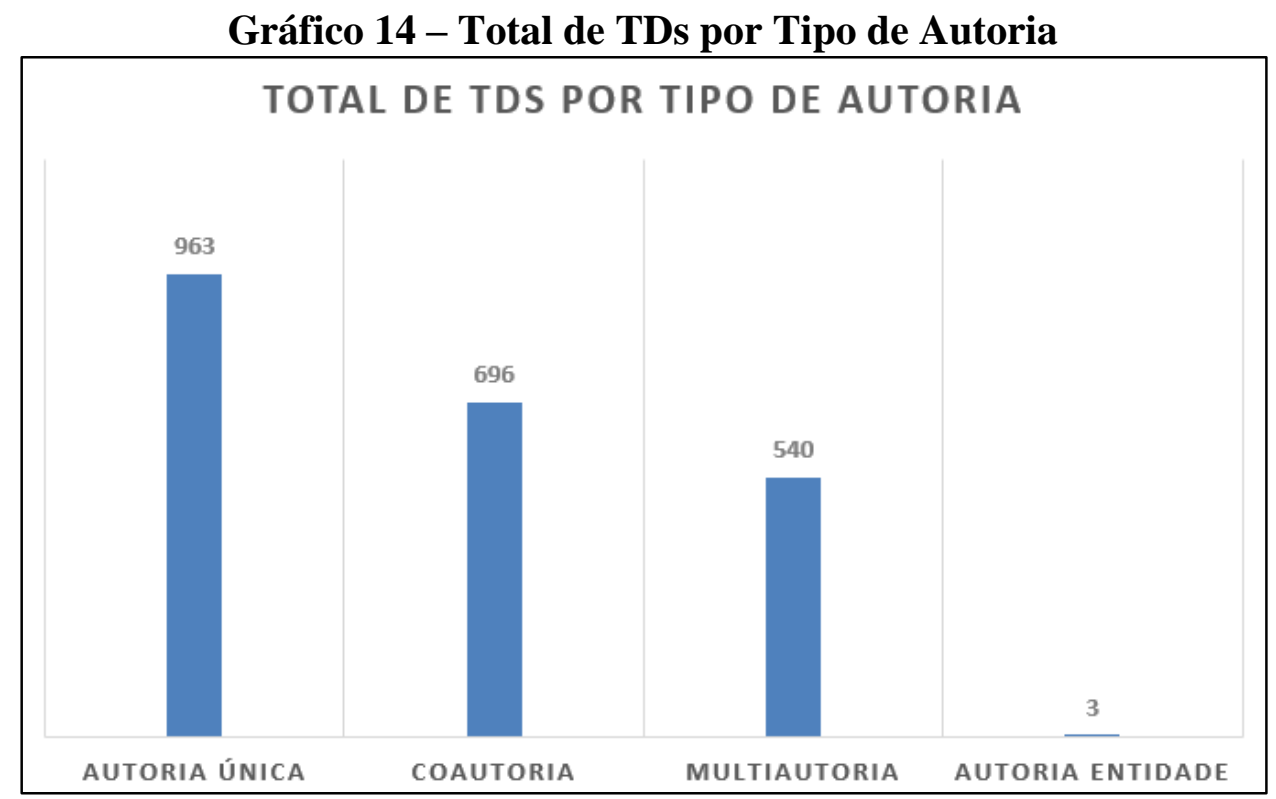

Nota: Elaboração da autora.

Inicialmente, optamos por separar os dados de coautoria e multiautoria, pois considerouse muito relevante o fato do número de trabalhos publicados por 2 autores, que totalizaram 696 trabalhos, ser superior ao número de trabalhos publicados por 3 ou mais autores, que totalizaram 540 trabalhos. Isso quer dizer que as relações entre dois autores são mais frequentes que as relações entre 3 ou mais autores nos TDs.

Ainda mantendo separados os dados de coautoria e multiautoria, verificamos que: $44 \%$ dos trabalhos foram publicados em autoria única (1 autor); $32 \%$ dos trabalhos foram publicados em coautoria (2 autores) e $24 \%$ dos trabalhos foram publicados em multiautoria (3 ou mais autores). 
Na Tabela 10 apresenta-se os dados quantitativos que se considerou para análise da multiautoria. Todos os dados de multiautoria, ou seja, todos os trabalhos publicados por 2 ou mais autores, foram incluídos.

Nesta análise conjunta, considerou-se os padrões adotados por pesquisadores que estudaram a multiautoria ou a coautoria, tais como Holmgren and Schnitzaer (2004), Hudson (1996) e Nabout (2014). Nesse sentido, buscou-se constatar se há um aumento no número de colaborações na pesquisa, ou seja, se existe uma tendência mundial à multiautoria nas publicações do Ipea, mais especificamente, na série periódica Textos para Discussão (TD) do Ipea. Buscava-se verificar se o que foi observado na literatura científica mundial, também seria observado na produção do Ipea.

O total de publicações em multiautoria é 1.236. Sabemos então que na série periódica Texto para Discussão (TD) do Ipea a maioria dos trabalhos publicados foram publicados por 2 ou mais autores. Ao todo, 56,2\% dos trabalhos foram publicados em colaboração, e $43,8 \%$ foram publicados em autoria única.

\section{Tabela 10 - Total de TDs por Multiautoria}

\begin{tabular}{|c|c|}
\hline Multiautoria & Total de TDs \\
\hline 2 autores & 696 \\
\hline 3 autores & 316 \\
\hline 4 autores & 128 \\
\hline 5 autores & 56 \\
\hline 6 autores & 18 \\
\hline 7 autores & 11 \\
\hline 8 autores & 7 \\
\hline 9 autores & 3 \\
\hline 14 autores & 1 \\
\hline
\end{tabular}

Nota: Tabela elaborada pela autora.

A Tabela 10 traz o quantitativo total de publicações em multiautoria organizado por $n^{\circ}$ de autores. Como podemos observar no gráfico abaixo, a colaboração entre autores ocorreu a partir da combinação de 2, 3, 4, 5, 6, 7, 8, 9 e 14 autores.

Verificou-se que, o maior grupo de autores, que se reuniu para escrever um TD, foi formado por 14 autores. Este TD foi publicado sob a coordenação da pesquisadora Anna Maria Peliano. Este fascículo reserva uma característica de grandes periódicos científicos, a reunião de artigos de autores diversos em um único fascículo.

Em ordem decrescente de número de autores, os demais trabalhos em multiautoria foram publicados da seguinte forma: 3 (três) trabalhos foram publicados por grupos de 9 autores; 7 (sete) trabalhos foram publicados por grupos de 8 autores; 11 (onze) trabalhos foram publicados por grupos de 7 autores; 18 (dezoito) trabalhos foram publicados por grupos de 6 autores; 56 (cinquenta e seis) trabalhos foram publicados por grupos de 5 autores; 128 (cento e vinte e oito) trabalhos foram publicados por grupos de 4 autores; 316 (trezentos e dezesseis) trabalhos foram publicados por grupos de 3 autores (tríades) 
e por fim, 696 (seiscentos e noventa e seis) trabalhos foram publicados por grupos de 2 autores (díades).

Os laços estabelecidos entre essas duplas, ou entre essas díades, são muito relevantes do ponto de vista da ARS. Refinar os resultados nos possibilitará mostrar com que frequência estas díades atuaram ao longo dos 37 anos da série periódica, e então descobrir quais díades se destacam em função do número de trabalhos que publicaram em conjunto.

Nesta etapa do trabalho buscou-se organizar os dados de autoria de acordo com o tempo, ou seja, ao longo dos 37 anos da série periódica. Dessa forma, interpretou-se os dados a partir desta importante variável, o tempo. Como visto no Gráfico 15, os dados de autoria única ao longo do tempo, observamos que o número total de trabalhos publicados em autoria única havia sofrido um incremento, assim como o número total de TDs publicados ao longo do tempo. Em outras palavras, percebemos que, assim como havia um aumento no número total de trabalhos publicados na série, havia um crescente número de trabalhos publicados em autoria única.

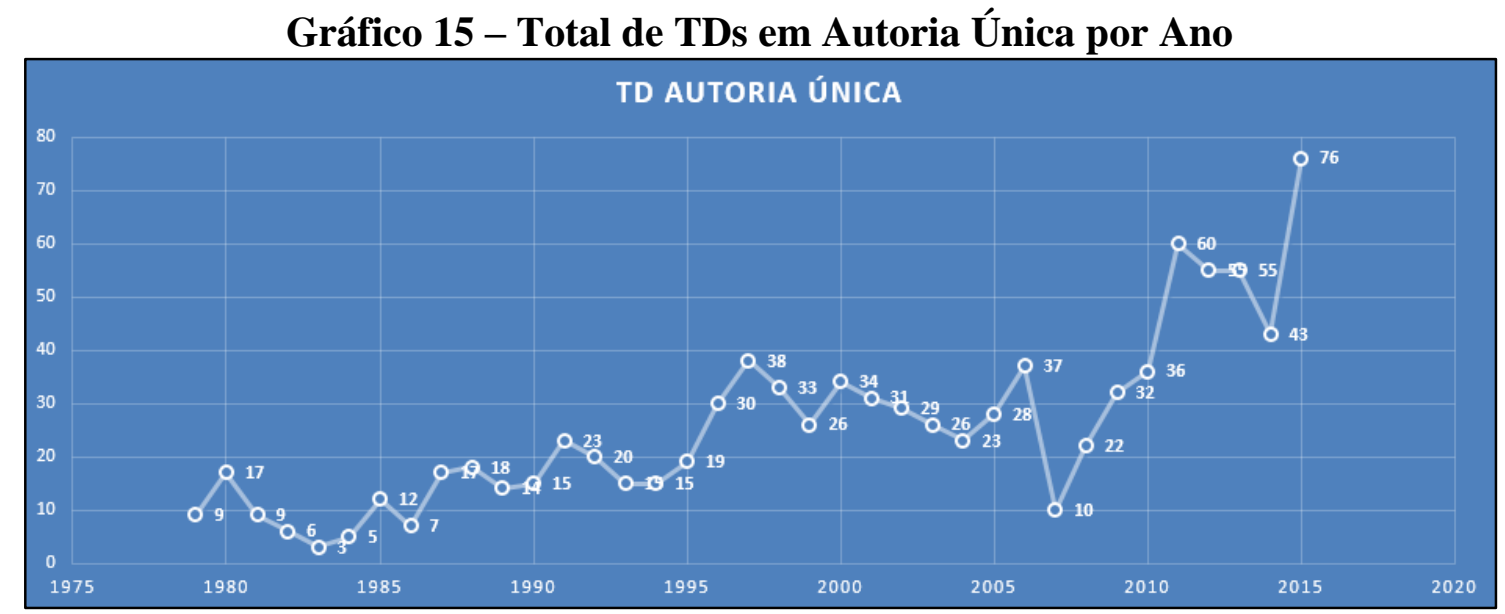

Nota: Elaboração da autora.

O gráfico acima mostra os dados de autoria única, ao longo dos 37 anos da série. Como visto, os dados de autoria única sofreram picos de incremento em determinados períodos. Observamos que estes picos de incremento coincidem com os picos de incremento da série como um todo. Nota-se no gráfico picos de incremento em 1997, 2006, 2011 e 2015.

Pensou-se então em organizar os dados de outra forma, para que pudéssemos observar a tendência de redução no número de trabalhos publicados em autoria única. Como dito, buscou-se estudar a autoria única, na série Texto para Discussão (TD) do Ipea, com o intuito de confirmar ou não, uma tendência observada na literatura científica mundial, em diversas áreas do conhecimento, quanto à tendência de redução do número de trabalhos publicados em autoria única.

Como visto, um crescente número de trabalhos publicados em autoria única foi observado, assim como um incremento no número total de trabalhos publicados na série. Deveríamos então calcular a proporção de trabalhos publicados em autoria única em comparação ao total de trabalhos publicados na série no mesmo período. 
Dessa forma, organizou-se os dados na tabela abaixo e calculou-se o número de trabalhos publicados em autoria única, em comparação ao número total de trabalhos publicados na série, para o mesmo período. Os dados de 2016 foram desprezados, uma vez que não seria possível contabilizar nestes resultados o total de publicações do ano 2016, visto que a coleta de dados foi encerrada em julho de 2016.

Tabela 11 - Número Total e Proporção de TDs em Autoria Única

\begin{tabular}{|c|c|c|c|}
\hline Ano & Total de publicações & TD autoria única & $\%$ autoria única \\
\hline 1979 & 12 & 9 & $75 \%$ \\
\hline 1980 & 19 & 17 & $89 \%$ \\
\hline 1981 & 11 & 9 & $82 \%$ \\
\hline 1982 & 12 & 6 & $50 \%$ \\
\hline 1983 & 7 & 3 & $43 \%$ \\
\hline 1984 & 8 & 5 & $62 \%$ \\
\hline 1985 & 16 & 12 & $75 \%$ \\
\hline 1986 & 16 & 7 & $44 \%$ \\
\hline 1987 & 28 & 17 & $61 \%$ \\
\hline 1988 & 32 & 18 & $56 \%$ \\
\hline 1989 & 23 & 14 & $61 \%$ \\
\hline 1990 & 24 & 15 & $62 \%$ \\
\hline 1991 & 34 & 23 & $68 \%$ \\
\hline 1992 & 45 & 20 & $44 \%$ \\
\hline 1993 & 39 & 15 & $38 \%$ \\
\hline 1994 & 35 & 15 & $43 \%$ \\
\hline 1995 & 33 & 19 & $57 \%$ \\
\hline 1996 & 57 & 30 & $53 \%$ \\
\hline 1997 & 86 & 38 & $44 \%$ \\
\hline 1998 & 79 & 33 & $42 \%$ \\
\hline 1999 & 79 & 26 & $33 \%$ \\
\hline 2000 & 80 & 34 & $42 \%$ \\
\hline 2001 & 79 & 31 & $39 \%$ \\
\hline 2002 & 82 & 29 & $35 \%$ \\
\hline 2003 & 70 & 26 & $37 \%$ \\
\hline 2004 & 56 & 23 & $41 \%$ \\
\hline 2005 & 85 & 28 & $33 \%$ \\
\hline 2006 & 108 & 37 & $34 \%$ \\
\hline 2007 & 66 & 10 & $15 \%$ \\
\hline 2008 & 51 & 22 & $43 \%$ \\
\hline 2009 & 92 & 32 & $35 \%$ \\
\hline 2010 & 86 & 36 & $42 \%$ \\
\hline 2011 & 141 & 60 & $42 \%$ \\
\hline 2012 & 120 & 55 & $46 \%$ \\
\hline 2013 & 114 & 55 & $48 \%$ \\
\hline 2014 & 94 & 43 & $46 \%$ \\
\hline 2015 & 142 & 76 & $53 \%$ \\
\hline 2016 & 41 & 18 & $44 \%$ \\
\hline
\end{tabular}

Nota: Tabela elaborada pela autora.

A partir destes novos dados, calculados para as publicações em autoria única, foi possível observar, comparativamente, ao longo dos 37 anos, a tendência de redução no número de trabalhos publicados em autoria única. 
Como mostra o Gráfico 16, a proporção de trabalhos em autoria única alcançou os maiores valores na década de 80, mais especificamente de 1979 a 1990; onde o percentual de trabalhos publicados em autoria única chegou a $89 \%$ em 1981, maior proporção verificada em 37 anos. Em 1993 a proporção de trabalhos em autoria única chega a 38\%. Em 1994 e 1995, a proporção de trabalhos em autoria única sobe novamente, mas volta a cair a partir de 1996, mantendo-se em queda até 2007, quando atinge o menor valor de todo o período. Em 2007, apenas $15 \%$ dos trabalhos publicados o foram em autoria única. Em 2008, a proporção de trabalhos em autoria única sobe novamente para $43 \%$, e se mantém nessa faixa até 2015, quando atinge 53\% dos trabalhos publicados.

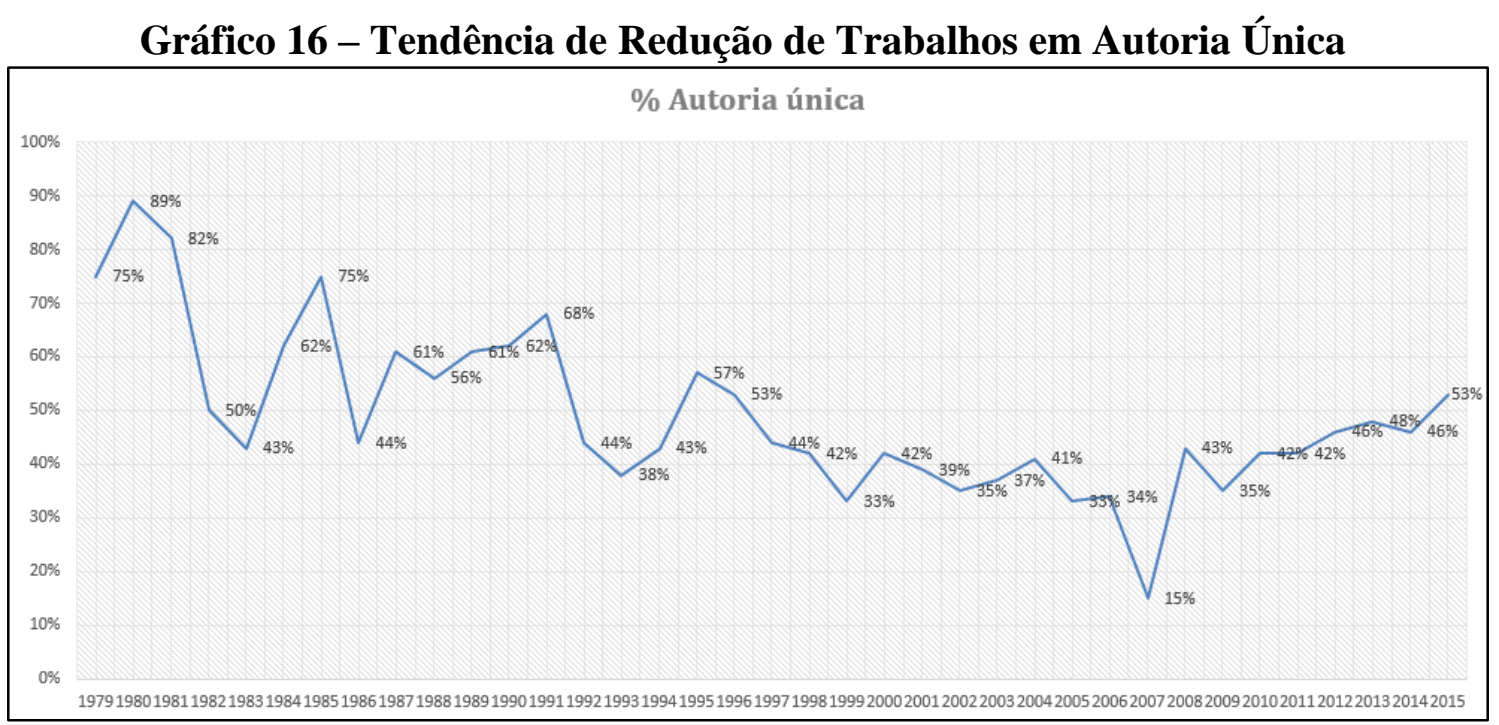

Nota: Elaboração da autora.

Obteve-se então os resultados relativos a análise da tendência de redução do número de trabalhos publicados em autoria única. O gráfico 16 mostra este comportamento e assim pode-se verificar que, proporcionalmente ao número total de trabalhos publicados na série periódica Texto para Discussão (TD) do Ipea, o número de trabalhos publicados em autoria única segue uma tendência de redução ao longo dos anos, acompanhando a tendência mundial observada na literatura científica. 
Complementarmente à análise relativa à tendência de redução do número de trabalhos em autoria única, foram organizados os dados e calculado o número de trabalhos publicados em multiautoria, em comparação ao número total de trabalhos publicados na série TD, para o mesmo período. Os dados de 2016 foram igualmente desprezados, uma vez que não seria possível contabilizar nestes resultados o total de publicações do ano 2016.

Tabela 12 - Número Total e Proporção de TDs em Multiautoria

\begin{tabular}{|c|c|c|c|}
\hline Ano & Total de publicações & TD multiautoria & $\%$ multiautoria \\
\hline 1979 & 12 & 3 & $25 \%$ \\
\hline 1980 & 19 & 2 & $11 \%$ \\
\hline 1981 & 11 & 2 & $18 \%$ \\
\hline 1982 & 12 & 6 & $50 \%$ \\
\hline 1983 & 7 & 4 & $47 \%$ \\
\hline 1984 & 8 & 3 & $38 \%$ \\
\hline 1985 & 16 & 4 & $25 \%$ \\
\hline 1986 & 16 & 9 & $46 \%$ \\
\hline 1987 & 28 & 11 & $39 \%$ \\
\hline 1988 & 32 & 14 & $44 \%$ \\
\hline 1989 & 23 & 9 & $39 \%$ \\
\hline 1990 & 24 & 9 & $38 \%$ \\
\hline 1991 & 34 & 11 & $32 \%$ \\
\hline 1992 & 45 & 25 & $56 \%$ \\
\hline 1993 & 39 & 24 & $62 \%$ \\
\hline 1994 & 35 & 20 & $57 \%$ \\
\hline 1995 & 33 & 14 & $43 \%$ \\
\hline 1996 & 57 & 27 & $47 \%$ \\
\hline 1997 & 86 & 48 & $56 \%$ \\
\hline 1998 & 79 & 46 & $58 \%$ \\
\hline 1999 & 79 & 53 & $67 \%$ \\
\hline 2000 & 80 & 46 & $58 \%$ \\
\hline 2001 & 79 & 48 & $61 \%$ \\
\hline 2002 & 82 & 53 & $65 \%$ \\
\hline 2003 & 70 & 44 & $63 \%$ \\
\hline 2004 & 56 & 33 & $59 \%$ \\
\hline 2005 & 85 & 57 & $67 \%$ \\
\hline 2006 & 108 & 71 & $66 \%$ \\
\hline 2007 & 66 & 56 & $85 \%$ \\
\hline 2008 & 51 & 29 & $57 \%$ \\
\hline 2009 & 92 & 60 & $65 \%$ \\
\hline 2010 & 86 & 50 & $58 \%$ \\
\hline 2011 & 141 & 81 & $58 \%$ \\
\hline 2012 & 120 & 65 & $54 \%$ \\
\hline 2013 & 114 & 59 & $52 \%$ \\
\hline 2014 & 94 & 51 & $54 \%$ \\
\hline 2015 & 142 & 69 & $47 \%$ \\
\hline
\end{tabular}

Nota: Tabela elaborada pela autora.

A partir dos dados contidos na Tabela 12, calculados para as publicações em multiautoria, foi possível observar, comparativamente, ao longo dos 37 anos, a tendência de aumento no número de trabalhos publicados em multiautoria.

Como visto, o número total de trabalhos em multiautoria vem aumentando ao longo do tempo. No início da década de 80 , o número total de trabalhos publicados em multiautoria era bem menor se comparados aos números atuais. Da mesma forma, observou-se um incremento no número total de trabalhos publicados na série. 
Calculamos então a proporção de trabalhos publicados em multiautoria em comparação ao total de trabalhos publicados na série no mesmo período. Os resultados relativos a análise da proporção de trabalhos publicados em multiautoria, em comparação ao número total de trabalhos publicados na série no mesmo período, mostrou uma tendência de aumento do $\mathrm{n}^{\mathrm{o}}$ de trabalhos publicados em multiautoria.

O gráfico 17 mostra o comportamento dos dados de multiautoria ao longo dos 37 anos da série periódica. Como podemos verificar, proporcionalmente ao número total de trabalhos publicados na série periódica Texto para Discussão (TD) do Ipea, o número de trabalhos publicados em multiautoria segue uma tendência de aumento ao longo dos anos.

Em 1980, registrou-se a menor proporção de trabalhos em multiautoria da série, onde apenas 11\% dos trabalhos foram publicados em multiautoria. De 1981 a 2007 observamos uma crescente tendência de aumento na proporção de trabalhos em multiautoria. Neste último ano, 2007, ocorreu a maior proporção de trabalhos em multiautoria da série, ano este que registramos a ocorrência de $85 \%$ dos trabalhos em multiautoria.

A partir de 2008 até 2015, a proporção de trabalhos em multiautoria cai um pouco, se comparada ao pico de 2007, mas não volta a apresentar proporcionalmente os números do início da série. Nestes últimos 7 anos, a proporção de trabalhos em multiautoria tem se mantido entre $65 \%$ e $47 \%$, como mostra o gráfico a seguir.

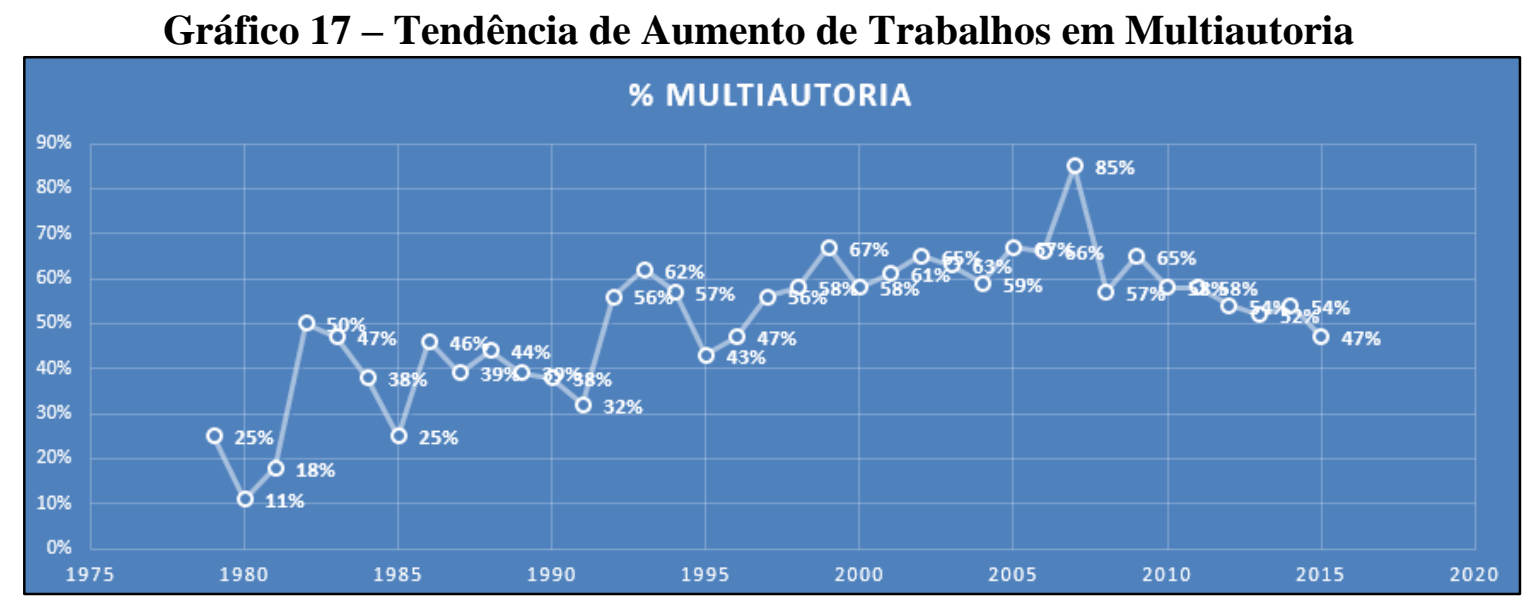

Nota: Elaboração da autora.

Acompanhando a tendência mundial observada na literatura científica, por diversos autores, em diferentes áreas do conhecimento, observamos que, na série periódica TD do Ipea, os trabalhos publicados também seguem essa tendência de aumento do número de trabalhos em multiautoria. Considerou-se os padrões adotados por pesquisadores que estudaram a multiautoria ou a coautoria, tais como Holmgren and Schnitzaer (2004), Hudson (1996) e Nabout (2014). 


\subsection{Resultado: análise formal}

Para entender as características da série periódica Textos para Discussão do Ipea, buscouse as definições oficiais para o Ipea e para os TD, as mais atuais possíveis, que fossem disponibilizadas inclusive nos próprios fascículos da série. A missão do Ipea, a definição para esta conhecida Fundação Pública, e uma definição para a série periódica, objeto de estudo deste trabalho, localizadas estão disponíveis a seguir. Vejamos então tais descrições:

Missão do Ipea colhida no TD 2222: “Aprimorar as políticas públicas essenciais ao desenvolvimento brasileiro por meio da produção e disseminação de conhecimentos e da assessoria ao Estado nas suas decisões estratégicas”.

Definição para o Ipea colhida no TD 2226: "Fundação pública vinculada ao Ministério do Planejamento, Desenvolvimento e Gestão, o Ipea fornece suporte técnico e institucional às ações governamentais - possibilitando a formulação de inúmeras políticas públicas e programas de desenvolvimento brasileiro - e disponibiliza, para a sociedade, pesquisas e estudos realizados por seus técnicos".

Definição para Textos de Discussão do Ipea colhida no TD 2226: "Publicação cujo objetivo é divulgar resultados de estudos direta ou indiretamente desenvolvidos pelo Ipea, os quais, por sua relevância, levam informações para profissionais especializados e estabelecem um espaço para sugestões".

Com base no referencial teórico da pesquisa e a partir da análise documental e coleta de dados, informações, críticas e tendências sobre avaliação de periódicos de diversos tipos, descrevemos a seguir as 52 (cinquenta e duas) características gerais encontradas em séries periódicas, periódicos, canais de comunicação para publicação de resultados de estudos e pesquisas e afins.

Além de realizar uma análise documental detalhada nos próprios Textos de Discussão (TD) do Ipea, ao longo de seus 37 anos de existência, como forma de classificá-los e atribuir a eles ou não as características resultantes desta parte da pesquisa, realizamos entrevista com alguns pesquisadores do Ipea e perguntamos a eles o que pensavam sobre a forma e as características dos TD. 
Tendo em vista os dados e as informações colhidas nos próprios fascículos da série TD do Ipea e as definições e diretrizes prospectadas na literatura científica sobre comunicação científica e ainda as informações colhidas nas entrevistas, apresentamos a seguir o resultado da análise formal, por meio do Quadro de análise das características da série periódica “Textos para Discussão (TD)" do Ipea.

Tabela 13 - Características da série "Textos para Discussão (TD)" do Ipea

\begin{tabular}{|c|c|c|}
\hline & $\begin{array}{l}\text { Características gerais de séries periódicas, periódicos, } \\
\text { canais de comunicação para publicação de resultados de } \\
\text { estudos e pesquisas, etc. }\end{array}$ & $\begin{array}{l}\text { Textos para Discussão } \\
\text { (TD) do Ipea }\end{array}$ \\
\hline 1 & Periodicidade pré-definida & SIM \\
\hline 2 & Fascículos sucessivos & SIM \\
\hline 3 & Título uniforme ou único & SIM \\
\hline 4 & Revisão pelos pares interna (Rede Ipea) & SIM \\
\hline 5 & Revisão pelos pares externa informal (Redes informais) & SIM \\
\hline 6 & Revisão por pares externa tradicional (Redes formais) & NÃO \\
\hline 7 & $\begin{array}{l}\text { Coletânea de artigos científicos de diferentes autores como } \\
\text { padrão }\end{array}$ & $\mathrm{NÃO}$ \\
\hline 8 & $\begin{array}{l}\text { Segue padrão básico para publicações científicas } \\
\text { (Titulo/Nome do Autor/Resumo/Corpo principal do } \\
\text { texto/Referencias) }\end{array}$ & SIM \\
\hline 9 & Informa data de submissão do original & $\mathrm{NÃO}$ \\
\hline 10 & Apresenta Resumo e Abstract & SIM \\
\hline 11 & Apresenta Sumário Executivo & SIM \\
\hline 12 & $\begin{array}{l}\text { Corpo Principal padrão (Introdução, metodologia, } \\
\text { resultados e conclusão) }\end{array}$ & NÃO \\
\hline 13 & Contém análise quantitativa & SIM \\
\hline 14 & Incluem tabelas e gráficos & SIM \\
\hline 15 & Consignam financiamento externo & NÃO \\
\hline 16 & $\begin{array}{l}\text { Disponível em Acesso Aberto, sem cobrança de taxas } \\
\text { (Open Access })\end{array}$ & SIM \\
\hline 17 & $\begin{array}{l}\text { Periódico nasceu em Acesso Aberto (Via Dourada ou Gold } \\
\text { Way) }\end{array}$ & SIM \\
\hline 18 & $\begin{array}{l}\text { Depositado em Repositório Institucional (Via Verde ou } \\
\text { Green Way) }\end{array}$ & SIM \\
\hline 19 & Contém Identificador Persistente (URI: DOI; Handle) & SIM \\
\hline 20 & Descrito em padrão Dublin Core & SIM \\
\hline 21 & Indexado pelo Science Citation Index (SCI) & NÃO \\
\hline 22 & Indexado pela REPEC & SIM \\
\hline 23 & Possui Fator de Impacto (FI) & SIM \\
\hline 24 & Possui impacto (citações) no Google Scholar Metrics & SIM \\
\hline 25 & $\begin{array}{l}\text { Contribuição para solução de problemas nacionais, } \\
\text { regionais e locais }\end{array}$ & SIM \\
\hline 26 & $\begin{array}{l}\text { Contribuição para a pesquisa e o desenvolvimento } \\
\text { nacionais }\end{array}$ & SIM \\
\hline 27 & Contribuição para a tecnologia e inovação nacionais & SIM \\
\hline 28 & Contribuição para o treinamento de novos pesquisadores & SIM \\
\hline 29 & Contribuição para o treinamento de técnicos em serviço & SIM \\
\hline
\end{tabular}




\begin{tabular}{|c|c|c|}
\hline 30 & $\begin{array}{l}\text { Contribuição para o aumento do prestígio nacional e } \\
\text { internacional }\end{array}$ & SIM \\
\hline 31 & $\begin{array}{l}\text { Contribuiçãa para a garantia da autonomia do país na } \\
\text { pesquisa em sua área de atuação }\end{array}$ & SIM \\
\hline 32 & Influencia a visão de mundo da sociedade & SIM \\
\hline 33 & $\begin{array}{l}\text { Há utilidade dos resultados publicados para o progresso da } \\
\text { área }\end{array}$ & SIM \\
\hline 34 & Há aceitabilidade do delineamento da pesquisa & SIM \\
\hline 35 & Tem importância teórica & SIM \\
\hline 36 & Há coerência entre a teoria e a investigação real & SIM \\
\hline 37 & Apresenta ideias criativas & SIM \\
\hline 38 & Apresenta novas comprovações empíricas & SIM \\
\hline 39 & $\begin{array}{l}\text { Apresenta níveis de conhecimento aprofundado sobre os } \\
\text { temas tratados }\end{array}$ & SIM \\
\hline 40 & Apresenta sofisticação de metodologia e análise & SIM \\
\hline 41 & Pertinência dos artigos para área de atuação do periódico & SIM \\
\hline 42 & Demonstração de sensibilidade ética & SIM \\
\hline 43 & Os resultados apresentados têm utilidade no cotidiano & SIM \\
\hline 44 & Os resultados apresentados têm utilidade no entretenimento & NÃO \\
\hline 45 & Os resultados têm originalidade & SIM \\
\hline 46 & $\begin{array}{l}\text { Os resultados são bem escritos e redigidos com correção e } \\
\text { coesão }\end{array}$ & SIM \\
\hline 47 & Foi mencionado em relatórios de PPG Nacionais & SIM \\
\hline 48 & $\begin{array}{l}\text { Tem pontuação atribuída pelo Sistema Qualis em } \\
\text { Economia }\end{array}$ & NÃO \\
\hline 49 & $\begin{array}{l}\text { Tem pontuação atribuída pelo Sistema Qualis em outras } \\
\text { áreas }\end{array}$ & SIM \\
\hline 50 & $\begin{array}{l}\text { Privilegia a autoria pessoal em detrimento da autoria } \\
\text { entidade }\end{array}$ & SIM \\
\hline 51 & Observa os trabalhos antecedentes e a reputação do autor & SIM \\
\hline 52 & Possui ISSN (International Standard Serial Number) & SIM \\
\hline
\end{tabular}

Nota: Tabela elaborada pela autora.

Como visto, considerou-se que os Textos para Discussão (TD) do Ipea correspondem favoravelmente a 44 características de um total de 52 características listadas. Os TD do Ipea corresponderam favoravelmente a $84,61 \%$ das características estudadas. Uma porcentagem bastante expressiva e que nos faz pensar como os periódicos e publicações afins, tais como os TD do Ipea, possuem relevância e impactam em nossa sociedade.

Existem, como destacam Meadows (1999) e Velho (2001), muitas outras funções e características encontradas nas publicações periódicas que são responsáveis pela divulgação e publicação de resultados de estudos e pesquisas em um país ou em uma determinada área do conhecimento.

Independentemente da avaliação internacional tradicionalmente atribuída às publicações, em função das métricas de impacto, pretendemos revelar com esta análise características 
que muitas vezes são encobertas pelas grandes métricas da ciência e dificultam a valorização desses importantes canais de comunicação.

O curioso é nos perguntarmos, se o Ipea seguir todas as "recomendações" internacionais relacionadas à qualidade da produção científica, a partir da obtenção de "selos de qualidade" e galgando posição em ranques internacionais, sua produção levará quantos anos para finalmente alcançar tal "status"? O Ipea deve então se preocupar em relação a "classificação" dos TD ou simplesmente seguir pesquisando e publicando os resultados nesse formato?

Por outro lado, os TD do Ipea não corresponderam favoravelmente à 08 características, de um total de 52 características listadas. Cerca de 15,38\% das características listadas nesta análise não puderam ser confirmadas para os TD do Ipea. Apresentamos a seguir um quadro que lista todas as 09 características não encontradas na série temporal TD do Ipea:

Em relação ao fato de os TD do Ipea não corresponderam favoravelmente a 08 características, de um total de 52 características listadas, é importante destacar que, como pontuado por Velho (2001), todos os canais de comunicação devem ser avaliados de acordo com os objetivos a que se propõem, visto que existem objetivos que orientam a constituição de seus formatos e tipologias. Com os TDs do Ipea não seria diferente, certamente existem objetivos institucionais que orientaram a criação e orientam ainda hoje os caminhos futuros desta importante série periódica.

O objetivo da análise formal da série TD do Ipea pretende levantar e registrar o conjunto de atributos e características que fazem da série Texto para Discussão (TD) do Ipea um importante canal de comunicação brasileiro, de acordo com as suas dinâmicas características de forma e de qualidade. 


\section{ANÁLISE DE REDES SOCIAIS (ARS)}

\subsection{Referencial Teórico}

As pesquisas sobre redes sociais são interdisciplinares e interessam a pesquisadores de várias áreas do conhecimento, os quais, com o objetivo de compreenderem o seu impacto sobre a vida social, deram origem a diversas metodologias de análise que têm como base as relações entre os indivíduos, numa estrutura em forma de redes. Nesse sentido, Emirbayer e Goodwin (1994) defendem que a análise de redes não é uma teoria formal ou unitária, mas uma ampla estratégia de investigação de estruturas sociais.

Wasserman e Faust (1999), dizem que uma rede social consiste de elementos ou atores, e laços, que estabelecem uma relação entre si. As relações estabelecidas podem ser de ordem afetiva, parentesco, afiliação ou de qualquer outro tipo de vínculo e a análise destas redes possibilita encontrar padrões e elementos-chave em uma determinada comunidade. Os elementos e atores podem ser pessoas, comunidades, grupos ou organizações.

Para Wellman (1983) o comportamento social é resultado tanto da posse individual de atributos e normas, como o resultado de seu envolvimento na estrutura das relações sociais. O autor refere-se a um importante pressuposto da ARS, conhecido como "imperativo anticategórico", que rejeita as tentativas de explicar o comportamento humano ou o processo social somente em função dos atributos dos atores.

Newman (2003) define uma rede como sendo "um conjunto de vértices ou nós conectados por arestas". A ligação existente entre vértices nos informa que há algum tipo de relacionamento entre dois ou mais objetos. Segundo Costa (2003), a rede é "uma forma de organização que pode ser caracterizada principalmente pela sua horizontalidade, isto é, pelo modo de inter-relacionar os elementos sem hierarquia".

Todavia, apesar desta diversidade de correntes e contribuições, a literatura cita três tradições principais nos métodos relacionais: 1) a análise sociométrica, que trabalhou com a compreensão das relações sociais desenvolvidas em pequenos grupos, a partir da utilização dos métodos da teoria dos grafos. Essa corrente foi influenciada pela Teoria da Gestalt, originando os conhecidos sociogramas; 2) os pesquisadores de Harvard, que exploraram características das relações interpessoais e a formação de cliques em grupos de trabalho de fábricas e pequenas comunidades. Essa vertente foi influenciada pelas ideias de Radcliffe-Brown, cientista social britânico, responsável pelo desenvolvimento da teoria do funcionalismo estrutural; por William Lloyd Warner e Elton Mayo; e 3) os antropólogos de Manchester, que investigaram as estruturas das relações em comunidades tribais e vilas, lançando mão de ambas as correntes anteriores.

Podemos dizer que a análise de redes sociais (ARS) nos permite medir estruturas e sistemas cuja descrição, sem conceitos relacionais, se tornaria praticamente impossível. A ARS promove a análise descritiva e testes de hipóteses sobre propriedades estruturais, sendo o método predominantemente estrutural. (Hanneman, 2001; Hanneman, e Riddle, 2005; Wasserman, e Faust, 1994).

Na década de 1940, verificou-se um salto expressivo nas possibilidades de mapeamento das relações. As bases da matemática e da álgebra linear beneficiou o estudo, que passou a representar as relações na forma de matrizes. O tratamento computacional permitiu a 
análise de grandes bases de dados, quando a partir de 1970, análises mais sofisticadas e de maior porte foram viabilizadas. (Marteleto, e Oliveira e Silva, 2004).

A colaboração científica é um dos atributos mais pesquisados com base na ARS, proporcionando uma visão ampla dos "colégios invisíveis" nos quais os vértices da pesquisa estão inseridos, além de uma série de outras constatações quanto às relações de união no âmbito científico. $\mathrm{O}$ crescimento do número de artigos publicados em âmbito mundial cuja temática é a ARS foi mencionada por Otte e Rousseau (2002).

Neste trabalho, as chamadas vértices, ou nodos, serão representadas pelos autores e as arestas, ou ligações, representarão o comportamento de publicação em coautoria entre os autores, dada a composição de cada grupo de autores formado para elaboração de cada Texto para Discussão (TD) do Ipea.

\subsection{Conceitos fundamentais}

A seguir, destacam-se alguns conceitos e definições sobre ARS considerados fundamentais, os quais estão disponíveis nas obras de Harary (1972), Granovetter (1973), Wasserman e Faust (1999).

Uma rede se constitui a partir de um conjunto de relações. Compõe-se de um conjunto de objetos, ou nós, e do mapa de suas ligações. A rede mais simples forma-se com dois nós, A e B, em uma relação que os liga. Uma rede representa um conjunto de nós, ou atores, ligados por laços específicos. Os laços traçam caminhos que ligam os atores. Os padrões de laços conformam uma determinada rede, que é povoada por seus nós. (Borgatti, e Foster, 2003; Borgatti, e Halgin, 2011).

Em contraste com os grupos, as redes não possuem limites naturais e não precisam estar conectadas. Redes desconectadas podem ser definidas como aquelas nas quais os nós, ou atores, não podem alcançar outros nós seguindo um caminho. Nesse caso, a rede encontrase em fragmentos denominados componentes. (Borgatti, e Halgin, 2011).

Tipos de rede: 1) O que é a rede egocentrada? Rede formada por uma nuvem de nós e de seus laços em torno de um dado nó; 2) O que é a rede sociocentrada? Rede dentro de uma caixa, ou rede de relações entre trabalhadores de uma mesma organização, constituindo redes fechadas; 3) O que é a rede "sistema aberto"? São aquelas redes cujos limites ou fronteiras não estão bem definidas, a exemplo de conexões entre organizações.

O ator, vértice ou nó é uma unidade flexível, que varia conforme a proposta de análise. Ele permite vários níveis de agregação, o que possibilita sua adequação a diferentes problemas. Um ator pode ser uma pessoa, um conjunto de pessoas, um subgrupo, uma organização e outras coletividades. Neste estudo, o ator é um autor/pesquisador responsável pela produção científica analisada no contexto do Ipea.

A interação é aquela ação que gera reflexo social entre os indivíduos e seus pares. Tem caráter social diretamente associado ao processo comunicativo.

O laço relacional, em inglês relational tie, é aquilo que estabelece a relação entre pares de atores. Esses laços podem ser classificados em três categorias, quais sejam, laços ausentes, laços fracos e laços fortes (GRANOVETTER, 1973). 
Laço é a efetiva conexão entre os nós ou atores. Laços são formas institucionalizadas de conexão entre pares de atores, constituídas no tempo. Existem diversos tipos de laço e a classificação dos laços entre "estado" e "evento" é importante para a definição dos tipos de medidas e de operações aplicáveis. O laço estado, ou contínuo, é aquele medido em termos de força, intensidade e duração; é contínuo ao longo do tempo. O laço evento, ou discreto, tem natureza transitória e pede medidas de frequência, de número de vezes.

Os laços podem não ser recíprocos. Os laços simétricos ou não direcionais podem ser definidos como aqueles que conectam dois ou mais atores, com a mesma força nos dois sentidos. Em estudos baseados em análises de coautoria, os laços são simétricos. Os laços assimétricos ou direcionais são aqueles que conectam dois indivíduos e que possuem forças diferentes nos dois sentidos. Em estudos baseados em análise de citação, os lações são assimétricos (Borgatti, e Foster, 2003; Granovetter, 1973).

Laços ponte conectam atores de diferentes redes ou clusters de uma mesma rede. São ligações entre dois indivíduos situados em agrupamentos distintos e não conectados, a não ser por essa ligação, que se torna a "ponte" entre os dois grupamentos.

Dizemos que atores gozam de condição de similaridade quando estão física e temporariamente próximos. Os atores apresentam similaridade por localização, quando ocorre a proximidade física e temporal; similaridade por afiliação, quando pertencem ao mesmo grupo, ou por atributos pessoais.

A relação social é considerada a unidade básica de análise em uma rede social, que envolve uma quantidade grande de interações. O conteúdo das interações auxilia na definição do tipo de relação social que existe entre os nós ou atores. Sabemos ainda que as relações variam em função de direção, conteúdo e força. Relação pode ser definida como todo conjunto de laços que respeite um mesmo critério de relacionamento, dado um conjunto de atores. As relações possuem duas propriedades que devem ser consideradas em todo método que se utilize desse conceito: direcionamento e valoração.

Em inglês, nodal degree, denotado por $\mathrm{d}\left(\mathrm{n}_{\mathrm{i}}\right)$ é o número de linhas incidentes em um só nó ou ator. Um grafo pode ser direcional ou não-direcional. Em estudos de ARS, que utilizam a análise de citação, existe o autor citado, uma direção da relação, e o autor que citou, outra direção. $\mathrm{Na}$ análise de coautoria, caso da presente pesquisa, onde todos os autores que se relacionam são coautores, só existe uma direção possível, é, portanto, nãodirecional.

Quanto ao direcionamento, temos então que as propriedades das relações em análise de coautoria na Rede Ipea são não-direcionais. Quanto à valoração, uma relação pode ser dicotômica, o que indica a ausência ou a presença de determinado laço; ou valorada, na qual se atribui peso à relação ou apontam-se, por exemplo, a quantidade de artigos produzidos em coautoria por um grupo determinado de pesquisadores.

Quanto à valoração, uma relação pode ser dicotômica, o que implica a presença ou ausência de um determinado laço; ou valorada, na qual se atribui peso à relação ou apontam-se, por exemplo, quantos artigos foram produzidos em coautoria por um determinado número de pesquisadores. 


\subsection{Um breve panorama conceitual sobre ARS}

A análise de redes sociais (ARS), em inglês "Social Network Analysis" (SNA) é uma abordagem que estuda as relações entre atores sociais, ou seja, a unidade de observação é composta pelo conjunto de atores e seus laços. Uma discussão aprofundada em todas as várias facetas dessa abordagem é oferecida por Wasserman e Faust (1999), os quais referem que uma rede social consiste de elementos ou atores - que podem ser pessoas, comunidades, grupos ou organizações - e laços, que estabelecem uma relação entre si. As relações estabelecidas podem ser de diversos tipos, de ordem afetiva, parentesco, afiliação ou de qualquer outro tipo de vínculo e a análise destas redes possibilita encontrar padrões e elementos-chave em uma determinada comunidade.

Para Barbosa, Byington e Struchiner (2000) rede pode ser definida como "um conjunto de nós conectados, em que estes nós podem ser pessoas, grupos ou outras unidades, e as ligações podem ser simétricas ou assimétricas". Os autores argumentam que o termo rede social "refere-se ao conjunto de pessoas em uma população e suas conexões".

Para esses autores, a análise de redes sociais fornece "um modo preciso para definir importantes conceitos sociais, alternativa teórica para o pressuposto de atores sociais independentes e um referencial para a testagem de teorias acerca das relações sociais estruturadas" (BARBOSA; BYINGTON; STRUCHINER, 2000, p. 41).

Para Molina (2005), as quatro principais escolas de análise de redes pessoais são: a escola de Manchester, a de estudos de comunidades, a de estudos de estimação do tamanho das redes pessoais e a de capital social. A análise estrutural da rede estuda mais precisamente os papéis e posições dos atores na rede. Nesse sentido, é necessário recorrer à teoria dos grafos, que fornece a base matemática para determinação de padrões e visualização das redes e das matrizes que devem ser utilizadas principalmente para os cálculos computacionais. Hayashi (2007) dizque a propriedade da teoria dos grafos mais utilizada para a análise da distância entre atores é o caminho geodésico, definido como o menor caminho entre dois nós, apesar de não ser o único. O diâmetro de uma rede é o maior caminho geodésico existente nela, o que pode nos dizer o quanto a rede é "compacta".

O aprofundamento na teoria dos grafos permite realizar cálculos e abordagens mais específicas para a análise dos dados, sendo possível analisar diversas propriedades e características de uma rede social. No entanto, ressaltam Rodrigues e Mustaro (2006) que cada análise de redes sociais deve ser específica para a população em estudo, aprofundando-se a área da análise pertinente para a pesquisa.

Um grafo está conectado se todo par de pontos estiver conectado por um caminho. Se ele estiver desconectado deve possuir no mínimo dois componentes. Cluster é um agrupamento ou subconjunto de atores dentro de um grafo que se relacionam; muitas vezes é usado como sinônimo de clique, que, na verdade, seria um subgrafo totalmente conectado, isto é, um grafo onde todos os vértices estejam conectados entre si. 


\subsection{Níveis de análise}

No nível de rede: a propriedade mais conhecida é a coesão, que se refere à conectividade da rede e inclui propriedades de densidade, tamanho e fragmentação. Detectam-se subgrupos e a estrutura caracterizada pela distribuição geral dos laços, o que inclui propriedades como centro e periferia de agrupamentos, de liberdade de escala e de grau de distribuição.

No nível do ator: o conceito mais aplicado é o de centralidade, que expressa a importância estrutural ou proeminência de um ator na rede.

No nível da relação (díade), as propriedades fundamentais são: coesão da díade, que abarca aspectos relativos à proximidade social entre os pares de atores, medida pelo indicador de distância geodésica (o menor caminho de um nó a outro); ou por multiplexidade (o número de diferentes tipos de relações que um par mantém); e equivalência, que corresponde à extensão em que pares de nós, ou pares de atores, desempenham papeis estruturais similares na rede.

\subsection{Direcionamento em redes de coautoria}

Consideramos também as redes como sendo não direcionadas, ou seja, a ligação $\mathrm{A} \rightarrow \mathrm{B}$ implica automaticamente na presença de ligação $\mathrm{B} \rightarrow \mathrm{A}$. Isso significa que se o autor A publica com o autor B o inverso é verdadeiro.Segundo Monteiro (2014), um grafo não direcionado $G$ é um par ordenado $G=(N, E)$, formado por um conjunto de nós, $\mathrm{N}=\{\mathrm{n} 1, \mathrm{n} 2, \ldots, \mathrm{nn}\}$ e um conjunto de ligações, $\mathrm{E}=\{\mathrm{e} 1, \mathrm{e} 2, \ldots, \mathrm{eE}\}$, onde $\mathrm{ek}=\{\mathrm{ei}, \mathrm{ej}\}$ conecta os nós i e j, no caminho de comprimento $\mathrm{k}$.

No exemplo a seguir, Figura 2, ilustra-se uma rede não direcionada de coautoria. Como é possível observar, essa primeira rede é formada por $\mathrm{N}=2$ e $\mathrm{E}=1$, produzindo o par ordenado $\mathrm{G}=(2,1)$.

Figura 2 - Rede Não Direcionada de Coautoria

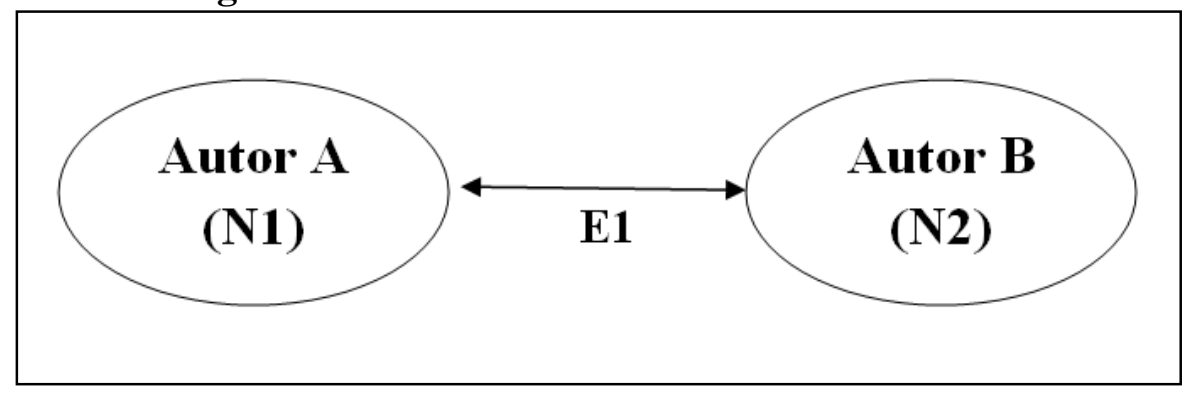

Nota: Figura elaborada pela autora. 
Neste outro exemplo, Figura 3, ilustrou-se uma rede não direcionada de coautoria quádrupla. Como visto, essa segunda rede é formada por $\mathrm{N}=4$ e $\mathrm{E}=6$, produzindo o par ordenado $\mathrm{G}=(4,6)$.

Figura 3 - Rede Não Direcionada de Coautoria Quádrupla

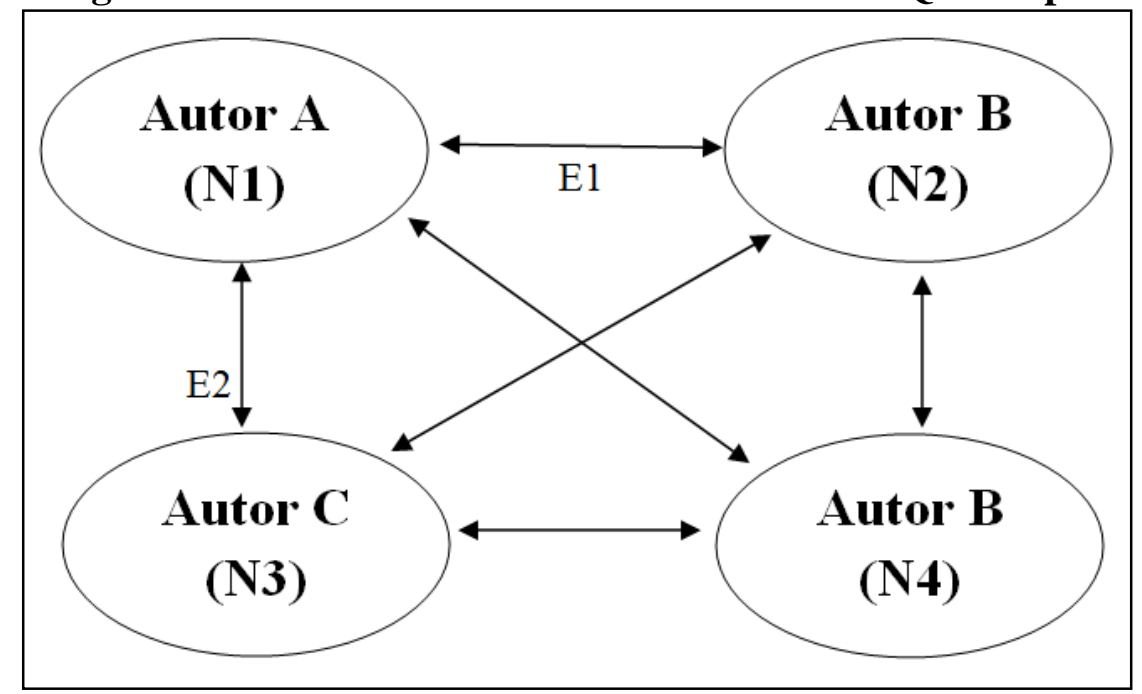

Nota: Figura elaborada pela autora.

Silva et. al. (2006a) abordam a utilização da ARS como um método a ser aplicado em estudos na Ciência da Informação, com base em informações bibliométricas, relacionadas à produtividade e à produção, de modo a construir importantes indicadores, principalmente para os formuladores de política científica, embora seja necessário admitir que se trate de uma proposta nova para a área no Brasil.

Marteleto (2001), discute a aplicação da ARS nos estudos do fluxo e transferência da informação de forma pioneira. Outros estudos no país têm sido desenvolvidos na área de Ciência da Informação com base na utilização da ARS e, além do trabalho de Marteleto (2001), destacam-se o estudo de Marteleto e Silva (2004), que reforça a importância da análise de redes sociais para o desenvolvimento econômico e de comunidades e grupos sociais.

Silva et al. (2006b), apresenta uma rede de coautoria científica dos Programas de PósGraduação de Ciência da Informação em funcionamento no Brasil. Di Chiara et al. (2006) apresenta uma pesquisa sobre redes sociais egocêntricas, centradas nos indivíduos, com base na análise de citações, sendo portando bidirecional e assimétrica. Oliveira (2006), que mostra uma pesquisa sobre ARS a partir de grupos de pesquisa no Brasil. 


\subsection{Resultados: análise da Rede Ipea}

Esta parte da pesquisa insere-se no escopo de estudos e pesquisas que utilizaram a Análise de Redes Sociais (ARS) aplicada à área de Ciência da Informação, mais especificamente à Comunicação Científica, e apresenta os resultados relacionados às redes de colaboração em pesquisa ou colaboração científica, a partir de um grupo central de autores vinculados ao Instituto de Pesquisa Econômica Aplicada (Ipea). A análise de coautoria permitiu a criação do banco de dados que utilizamos para estudar a rede de pesquisa do Ipea, ao longo dos 37 anos da série periódica Textos para Discussão (TD) do Ipea.

Do ponto de vista da análise de coautoria, o objeto de estudo mostrou-se um dos mais ricos para o entendimento da Rede de Pesquisa do Ipea, seus principais atores e componentes. Para se ter uma ideia, o banco de dados construído e os resultados da pesquisa abrem caminhos para uma análise longitudinal das Redes, onde será possível descrever a evolução estrutural da Rede, por exemplo, em 37 grafos. A análise longitudinal permitirá, por exemplo, entender as mudanças ocorridas na Rede de Pesquisa do Ipea ao longo dos anos, destacando os principais vértices que foram ou ainda são importantes para o Ipea. A análise estrutural da rede objetiva estudar os papéis e posições dos autores na rede, e para tanto precisa recorrer a teoria dos grafos (caminho geodésico), que fornece a base matemática para determinação de padrões e visualização das redes e das matrizes que devem ser utilizadas para os cálculos computacionais.

Interessante acompanhar os pesquisadores que no passado tiveram um papel importante (cutpoints), do ponto de vista da composição da Rede, com o passar dos anos podem desaparecer da Rede e levar consigo atores (nós) que estão ligados à Rede somente a partir desses atores, que desempenham o papel de ligar blocos a rede.

O estudo identificou redes de colaboração em pesquisa, entre pesquisadores do Ipea, que estabeleceram relações de coautoria entre si e com outros pesquisadores do país e do exterior. Os vértices da rede de colaboração, também chamados de nós, ou simplesmente atores, são esses autores que publicaram trabalhos, em coautoria, na série periódica "Textos para Discussão (TD)" do Ipea. Os dados de coautoria, ao contrário dos dados de citação, são considerados dados duros para análise de redes sociais. Não há como termos dúvidas sobre a relação estabelecida, pois ela está impressa na autoria dos trabalhos.

Por meio do levantamento das colaborações em pesquisa foram identificadas as possíveis relações de união e grau de colaboração dos membros dessa rede. Os resultados apontam a relevância do estudo de redes de coautoria no estudo da produção científica de um grupo de pesquisa. A rede é formada principalmente por: membros vinculados ao Ipea (Ipeanos); pesquisadores visitantes; bolsistas e assistentes de pesquisa. Compõem a rede, além dos Ipeanos, professores e pesquisadores de Institutos de Pesquisa e Instituições de Ensino Superior (IES) e membros da Administração Pública Brasileira. A lista com os nomes de todos os atores que compõem a rede está disponível no anexo 1. Utilizamos códigos para que fosse mais fácil colocar etiquetas nos grafos e, eventualmente, pudéssemos publicar partes do trabalho preservando o anonimato dos atores da rede.

No início desta pesquisa, acreditávamos que ao reunir todos os autores em uma matriz quadrática, poderíamos obter informações claras o suficiente para apresentarmos os principais resultados da análise da rede do Ipea. Sabíamos que cerca de 1.410 diferentes autores estavam conectados em uma grande rede. As relações de coautoria foram 
estabelecidas em torno da elaboração de 1.237 trabalhos, que foram publicados de 1979 a 2016, em coautoria, ou seja, com a composição mínima de um par de autores, 2 autores, até a composição máxima, de 14 autores.

Ao se analisar os dados com a ajuda do software UCINET (BORGATTI, 2002), a rede foi reorganizada e obteve-se o primeiro desenho da Rede Ipea, Gráfico 18. Esse foi o primeiro grafo da rede que de obteve, a partir desta matriz inicial com cerca de 1.410 autores. Apesar de mostrar muito pouco dos atores, mostrou a grande rede de pesquisa do Ipea ao longo dos 37 anos. Esse resultado foi o ponto de partida para que se pudesse aprofundar um pouco mais os resultados desta pesquisa no que se refere a ARS.

O Gráfico 18 é o primeiro mostra um resultado muito interessante, que revelou o desenho da rede total do Ipea, constituída de 1979 a 2016. Este resultado gráfico não apresentou os dados a partir da centralidade de grau dos atores, ou da centralidade de intermediação, que aponta quem são "cutpoints" na rede, em função da quantidade de dados, mas revelou a grande estrutura da rede.

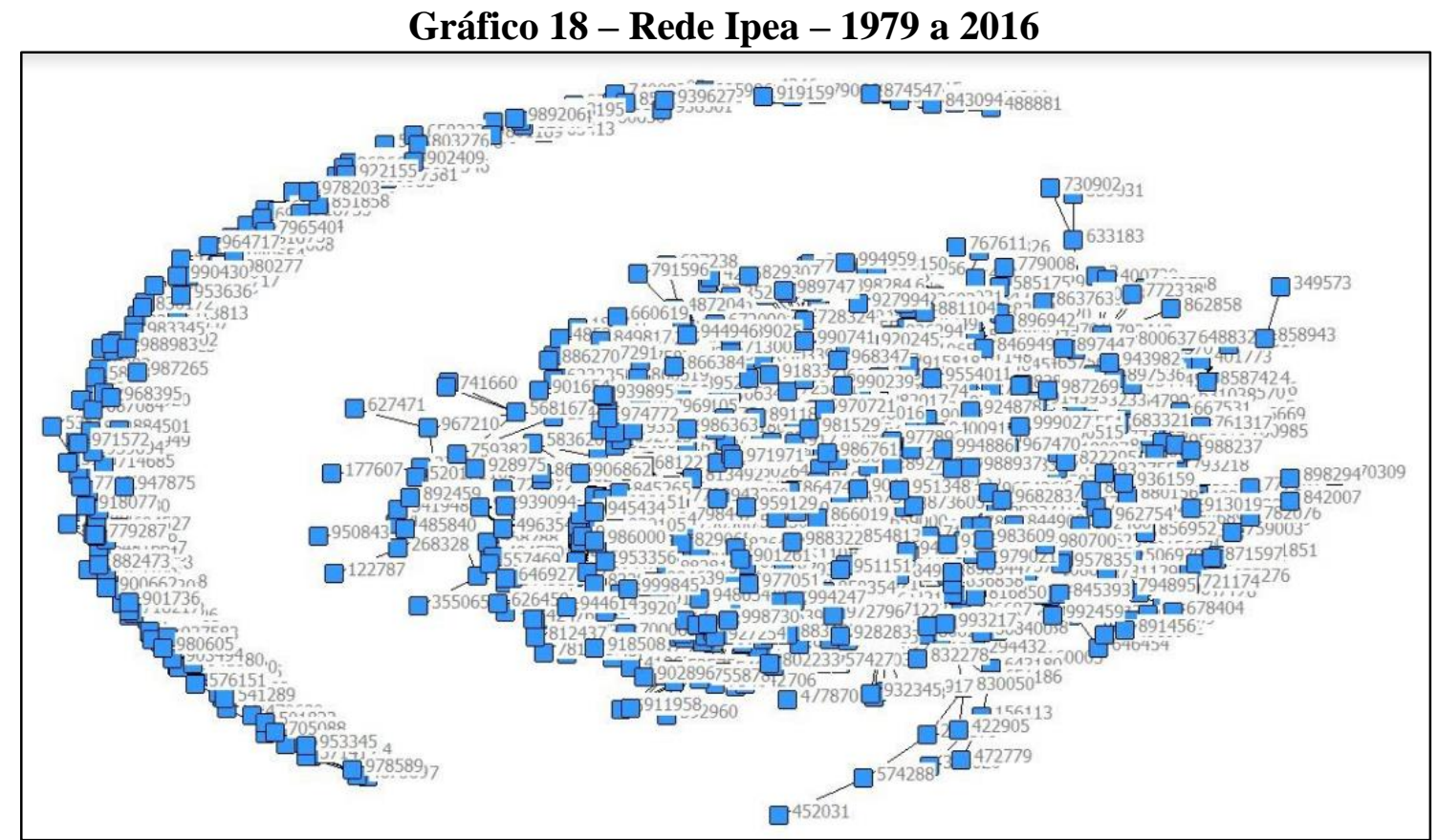

Nota: Elaboração da autora.

Foi possível identificar no grafo acima um componente muito grande, onde vários atores estavam ligados entre si e mais um conjunto de outros componentes, ou sub-redes, que não estavam ligados a essa grande rede.

O grande componente, da forma como está representado Gráfico 18, não permite a visualização detalhada dos atores, mas sabemos, por exemplo, que os atores não estão todos conectados entre si nesse grande componente. Os pequenos componentes aparecem todos aglomerados nessa representação gráfica, no entanto, a partir do grafo 1 não foi possível identificar quantos são os pequenos componentes e quem são os atores que fazem parte deles.

Como pode-se perceber, adotou-se um código numérico de seis dígitos para representar cada um dos atores da rede. A inclusão dessas etiquetas, que identificam quem são os 
pesquisadores da rede Ipea, auxilia a análise da rede, principalmente no nível dos atores e das ligações. Ao visualizarmos todos os "Labels", como mostra o grafo 1, tem-se uma visão confusa da rede, onde a quantidade de atores marcados, não nos permitiram visualizar nem os próprios atores, nem os laços existentes entre os atores. Além disso, não tínhamos as imagens gráficas geradas a partir dos dados de centralidade do nó e cutpoints da rede. Percebemos então, que se quiséssemos apresentar um resultado mais detalhado, deveríamos estudar a rede de pesquisa do Ipea a partir de períodos. Deveríamos dividir a análise de coautoria de 37 anos em períodos menores.

\subsection{A escolha dos períodos para análise da Rede de pesquisa Ipea}

O gráfico abaixo ilustra o aumento médio observado na produção do Ipea ao longo dos 37 anos da série periódica Texto para Discussão (TD) do Ipea. Podemos constatar que o incremento na produção anual de Textos para Discussão foi acompanhado pelo aumento no número de autores. Ao verificarmos a correlação entre o número de trabalhos publicados e a quantidade de autores envolvidos, que demonstraram ter um alto grau de correlação, decidimos estudar a rede a partir de quatro períodos, conforme mostramos no gráfico abaixo.

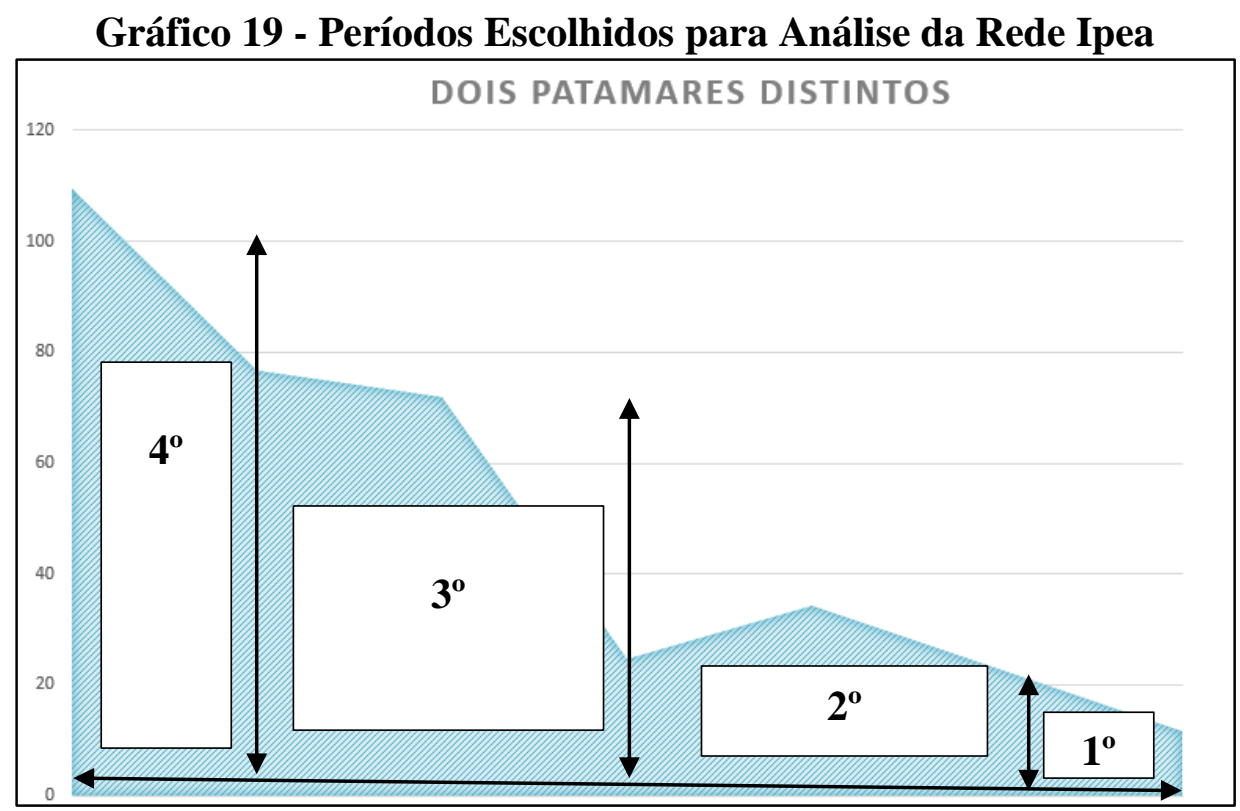

Nota: Elaboração da autora.

Decidiu-se estudar a rede a partir de quatro períodos, como mostra o Gráfico 19. O primeiro período escolhido para a análise da Rede Ipea foi de 1979 a 1984; o segundo período escolhido foi de 1985 a 1994; o terceiro período escolhido foi de 1995 a 2010 e o quarto período escolhido foi de 2011 a 2016. Ao todo estudamos a rede ao longo dos 37 anos de existência da série periódica.

O primeiro período corresponde aos dados de coautoria dos primeiros 6 (seis) anos da série, de 1979 a 1984. O segundo período corresponde aos dados de coautoria dos 10 (dez) anos seguintes, de 1985 a 1994. O terceiro período corresponde aos dados de coautoria de 16 (dezesseis) anos da série. O quarto e último período corresponde aos dados de coautoria dos 5 (cinco) últimos anos e cinco meses da série, de 2011 a 2016. 


\subsection{O primeiro período escolhido para a análise da Rede Ipea: 1979 a 1984}

As redes não possuem limites naturais e não precisam estar conectadas. Redes desconectadas podem ser definidas como aquelas nas quais os nós, ou atores, não podem alcançar outros nós seguindo um caminho. Nesse caso a rede encontra-se em fragmentos denominados componentes. (Borgatti, \& Halgin, 2011).

O Gráfico 20 abaixo traz o desenho da rede para este primeiro período. A rede nesse período é desconectada, ou seja, não é possível estabelecer um caminho entre determinados nós e outros tantos. Pode-se observar, que neste início, a Rede do Ipea era formada por cinco componentes. Um grande componente, a esquerda do grafo, e mais quatro pequenos componentes, organizados a direita do grafo.

Cada ponto da rede abaixo é um indivíduo ou ator. Cada linha representa um vínculo entre os atores. Um par de atores conectados por um vínculo formam uma díade e um trio de atores conectados formam uma tríade. Um número maior de atores e seus vínculos formam subgrupos. Temos então um subgrupo de 15 atores, uma díade e três tríades.

\section{Gráfico 20 - Rede Ipea - 1979 a 1984 - Centralidade de Grau}

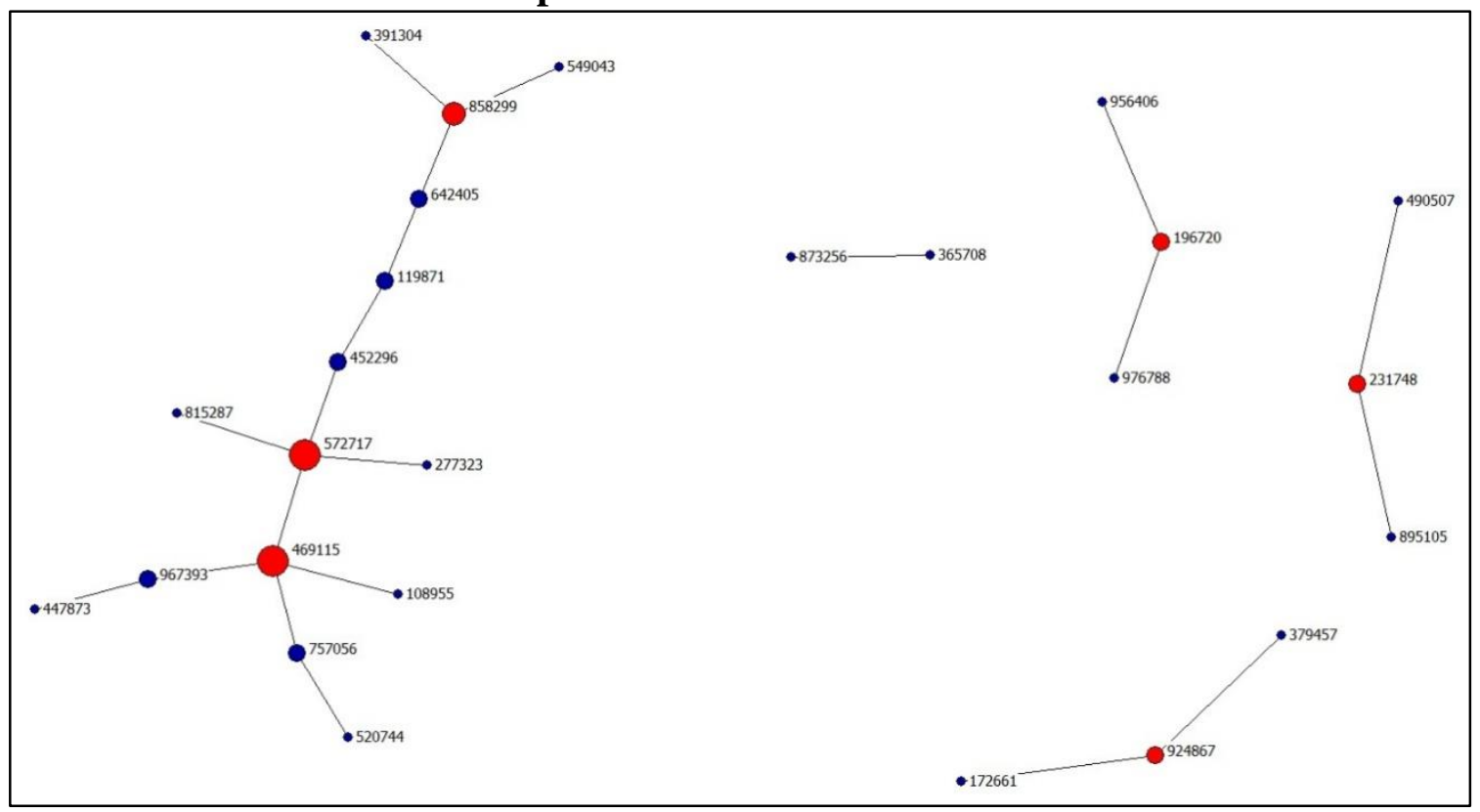

Nota: Elaboração da autora.

Como visto, seis (6) atores importantes da rede estão marcados no grafo 2 por pontos de cor vermelha. Os atores mais importantes ocupam posições estratégicas na rede. Várias medidas de importância podem ser utilizadas e nos interessam as medidas ligadas ao conceito de centralidade.

Uma das formas que temos para definir a centralidade de um ator é pensá-la em função das "atividades" de um ator. A quantidade de vínculos ou conexões que cada ator possui com outros atores da rede definirá qual o ator é mais ativoquando comparado aos demais. O número de conexões nos fornece o grau de centralidade absoluto de um ator. Os seis pontos vermelhos representam atores com maior grau nodal. $O$ grau nodal ou a centralidade de grau é medida pelo número de laços que um ator possui com outros atores em uma rede. (Wasserman, \& Faust, 1994). 
Esses são os atores considerados os principais atores desta rede. Quanto mais centrais são os atores em uma rede, mais importantes são esses atores. Os atores 572717 e 469115 possuem a maior grau nodal ou número de laços com outros atores, ambos possuem grau nodal igual a 4. São estes dois os principais atores da rede Ipea neste período e estão localizados no componente principal da rede, figura 2.

O terceiro ator mais importante é o 858299, que possui grau nodal igual a 3, ou seja, possui 3 laços com outros atores na rede e também está localizado no componente principal da rede, Gráfico 21.

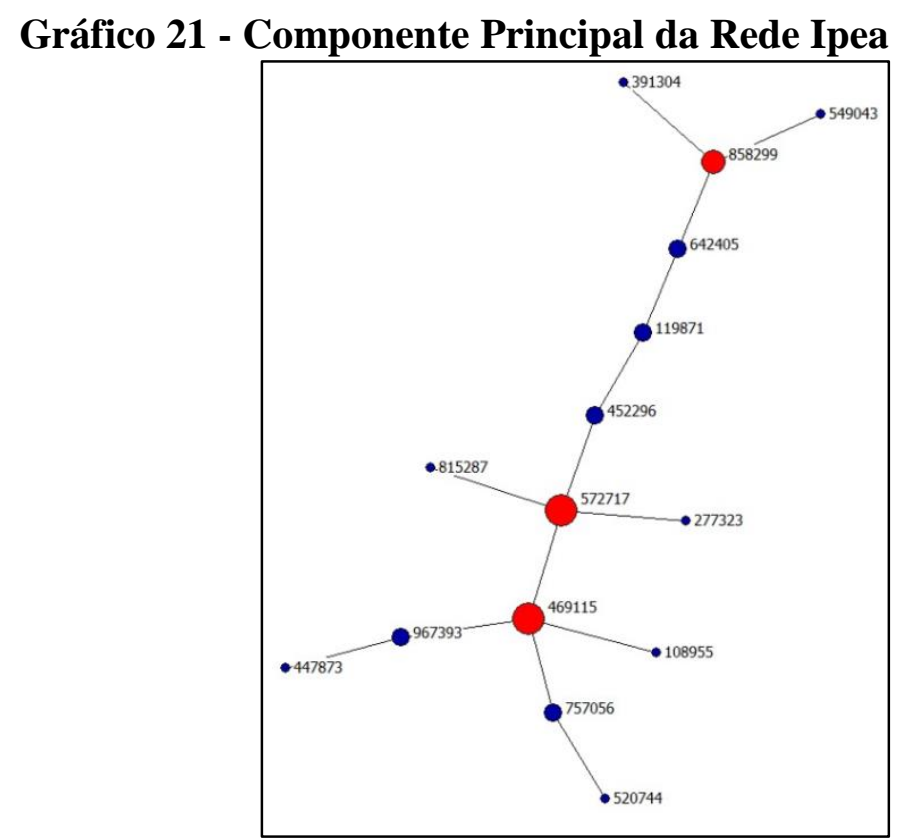

Nota: Elaboração da autora.

Os outros três atores marcados de vermelho no Gráfico 22, o 196720, o 231748 e o 924867 pertencem a diferentes componentes da rede e também são apontados como atores centrais na rede. Possuem grau nodal igual a 2 e estão em tríades na rede, como se pode verificar.

Gráfico 22 - Componentes Secundários da Rede Ipea - 1979 a 1984

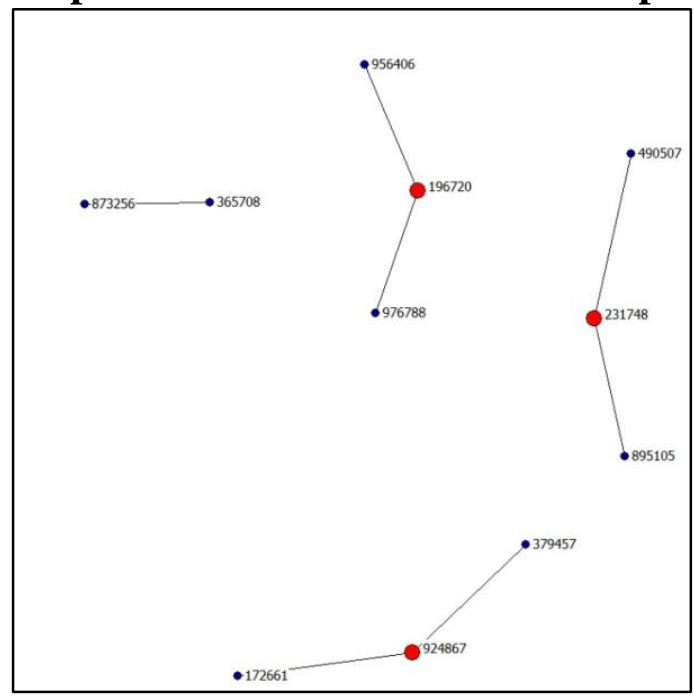

Nota: Elaboração da autora. 
Outros cinco atores têm grau de centralidade igual a 2 e os demais atores têm centralidade igual a 1. Possuir um alto grau nodal em relação aos demais nós da rede significa, para o pesquisador, que ele é um ator mais ativo na rede, ou seja, que ele possui maior número de publicações em coautoria e com o maior número de coautores do que outros pesquisadores.

Relacionou-se na Tabela 14 abaixo as medidas de centralidade de todos os atores da rede no primeiro período.

Tabela 14 - Centralidade de Grau dos Atores no Período de 1979 a 1984

\begin{tabular}{|c|c|c|}
\hline & Atores & Grau \\
\hline 1 & 469115 & 4 \\
\hline 2 & 572717 & 4 \\
\hline 3 & 858299 & 3 \\
\hline 4 & 119871 & 2 \\
\hline 5 & 196720 & 2 \\
\hline 6 & 231748 & 2 \\
\hline 7 & 452296 & 2 \\
\hline 8 & 642405 & 2 \\
\hline 9 & 757056 & 2 \\
\hline 10 & 924867 & 2 \\
\hline 11 & 967393 & 2 \\
\hline 12 & 108955 & 1 \\
\hline 13 & 172661 & 1 \\
\hline 14 & 277323 & 1 \\
\hline 15 & 365708 & 1 \\
\hline 16 & 379457 & 1 \\
\hline 17 & 391304 & 1 \\
\hline 18 & 447873 & 1 \\
\hline 19 & 490507 & 1 \\
\hline 20 & 520744 & 1 \\
\hline 21 & 549043 & 1 \\
\hline 22 & 815287 & 1 \\
\hline 23 & 873256 & 1 \\
\hline 24 & 895105 & 1 \\
\hline 25 & 956406 & 1 \\
\hline 26 & 976788 & 1 \\
\hline
\end{tabular}

Nota: Tabela elaborada pela autora.

Como visto, a centralidade de grau é medida pelo número de laços que um ator possui com outros atores em uma rede. Em termos absolutos, um ator A, presente em uma rede com $\mathrm{X}$ números de autores, pode ter, no máximo, $(\mathrm{X}-1)$ laços.

Clique é uma sub-rede ou subgrafos completo, com três ou mais nós em uma rede, na qual todos os nós estão diretamente conectados por linhas. (Scott, 2000; Wasserman e Faust, 1994). Para Harary (1972), o conceito de clique não está limitado ao número de nós, para o autor um componente completo ou clique é aquele que possui o maior número de relações possíveis entre os seus membros. 
Clique é um conceito fundamental para estudar a coesão de subgrupos na rede, para o qual um conceito preciso é fornecido pela teoria dos grafos. Neste sentido, concluiu-se que existe apenas 1 clique ou subgrafo completo no primeiro período, formado pela díade de atores conforme o Gráfico 23.

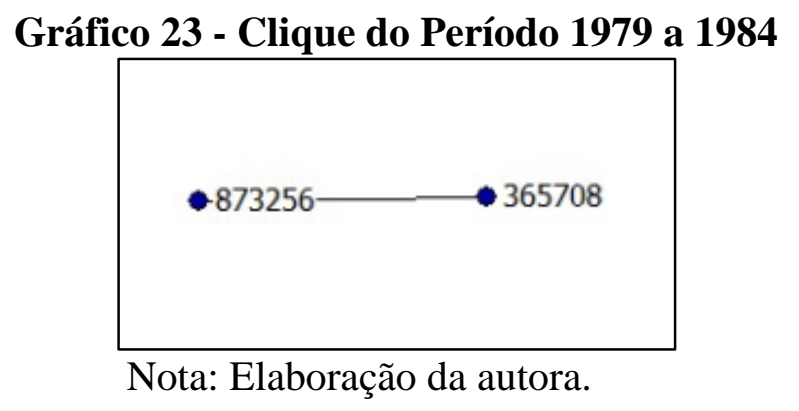

Os cliques são importantes, pois além de desenvolver em seus membros comportamentos homogêneos, eles têm, por definição, grande proximidade, com maior velocidade nas trocas que fazem. Informações dirigidas a um determinado clique são rapidamente absorvidas pelos seus membros.

No contexto da análise de grupos, um outro conceito apresentado é o conceito de Clans. Um clan pode ser definido quando os atores de um grupo não estão todos conectados diretamente, mas por meio de intermediários, onde a distância máxima é de dois ou mais passos, temos um clan. Pode-se então considerar que os 3 (três) componentes secundários do primeiro período, figura 5, com 3 (três) nós cada, são clans. Como visto, o grau de exigência para formação de cliques é muito maior do que os dos clans, que apresentam uma definição mais liberal de grupos. O Gráfico 24 mostra um dos três componentes secundários com três atores que classificamos como clan.

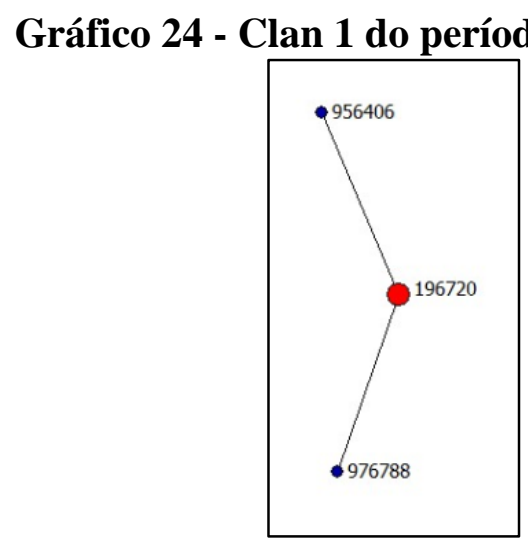

Nota: Elaboração da autora.

Na visão de Borgatti e Halgin (2011), o modelo de aplicação da ARS, denominado modelo relacional, foi projetado por Cook e Emerson (1978), que realizaram estudo experimental pioneiro sobre poder em redes de negócios. Nesse contexto, os autores modelaram um padrão específico de relações de negociação entre três atores. Se considerarmos a análise a partir do modelo relacional e o exemplo contido no Gráfico 24, o ator central, o 196720, tem duas alternativas de negociação, o ator 956406 e 976788 . Já os atores que estão nas pontas da sub-rede são totalmente dependentes do ator central. 
Essa vantagem do ator 196720, que deriva de sua posição na rede, é diferente do conceito de centralidade do modelo de fluxo.

No contexto institucional, a presença de clans em uma rede significa que "comunidades" se formaram dentro da organização. A presença dos clans pode ter relação com a organização interna da instituição. Se esta "comunidade" não estava prevista na estrutura formal da instituição, ela é ainda mais relevante e curiosa. Isso significa que as pessoas destas "comunidades" colaboram entre si de forma voluntaria e cabe à organização aproveitar todo o potencial que isso pode trazer.

Uma outra medida de centralidade é chamada de intermediação ou betweenness. Neste caso a centralidade está relacionada ao fato de um ator conectar subgrupos ou blocos, que de outro modo estariam desconectados.

Nesse sentido, de acordo com Freeman (1979) e Wasserman e Faust (1994) um ator é intermediário se ele liga vários outros atores que não se conectam diretamente. A centralidade de intermediação aborda a questão do controle que esses atores intermediários possuem sobre aqueles atores que dependem localmente deles.

Os atores com maior grau de centralidade de intermediação estão mais bem posicionados na rede se comparados aos demais atores, então o ator com alto grau de intermediação é um pesquisador que está mais bem posicionado na rede em relação aos demais. O Gráfico 25 apresenta os atores com maior grau de intermediação na Rede Ipea de 1979 a 1984. Pode-se chamar os atores com maior grau de intermediação de cutpoints. De um total de 26 atores, apenas 11 atores possuem grau de intermediação.

Gráfico 25 - Rede Ipea - 1979 a 1984 - Centralidade de Intermediação

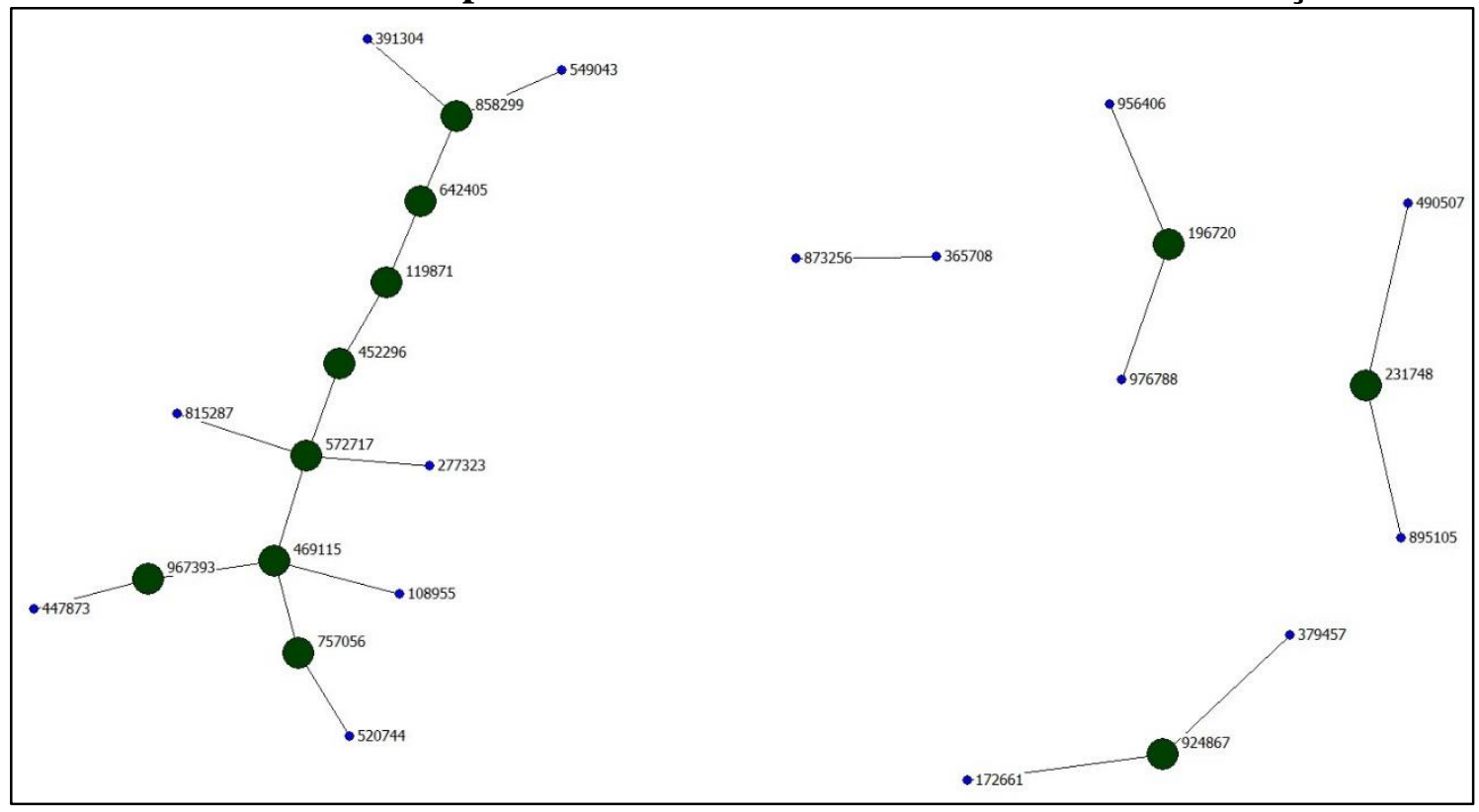

Nota: Elaboração da autora. 
Sabe-se então, que neste primeiro período, $42,3 \%$ dos atores fizeram a intermediação de mais relações de coautoria do que os demais autores. De certa forma pode-se considerar que os 11 atores com grau de intermediação igual a 1, listados na Tabela 15, contribuem para que a rede seja menos fragmentada. Esses atores ligam atores na rede que de outra forma não estariam conectados.

\section{Tabela 15 - Centralidade de Intermediação dos Atores no Período de 1979 a 1984}

\begin{tabular}{|c|c|c|}
\hline & Ator & Grau de intermediação \\
\hline 1 & 119871 & 1 \\
\hline 2 & 196720 & 1 \\
\hline 3 & 231748 & 1 \\
\hline 4 & 452296 & 1 \\
\hline 5 & 469115 & 1 \\
\hline 6 & 572717 & 1 \\
\hline 7 & 642405 & 1 \\
\hline 8 & 757056 & 1 \\
\hline 9 & 858299 & 1 \\
\hline 10 & 924867 & 1 \\
\hline 11 & 967393 & 1 \\
\hline
\end{tabular}

Nota: Tabela elaborada pela autora. 


\subsection{Análise da Rede Ipea: 1979 a 1984}

O tamanho da rede é definido pela quantidade de ligações existentes entre os atores. A rede deste primeiro período tem 26 atores, ligados por 21 laços. O tamanho da rede no primeiro período é 21 .

Podemos considerar as medidas de centralidade de todos os atores para inferir algumas propriedades da rede como um todo. Ao somarmos os graus de todos os atores (42) e dividirmos pelo número de atores (26), teremos o grau médio da rede. A soma dos graus de todos os atores, tabela 1 , é $=42$. Se dividirmos 42 por 26 , teremos que o grau médio da rede $=1,61$.

Na rede do primeiro período, que possui 26 atores, podemos dizer que cada ator pode ter, no máximo, grau absoluto $=25$. No primeiro período, 25 é o número de laços possíveis para qualquer ator na rede. Em termos relativos, para saber o grau de centralidade de um ator, basta dividir seu número de laços pelo número de laços possíveis.

Densidade da rede é dada pelo quociente entre o número de ligações existentes (21), pelo número de ligações possíveis (25). A densidade retrata a potencialidade da rede em termos de fluxo de informações. Quanto maior a densidade, mais intensa é a troca de informações na rede e vice-versa, quanto menor a densidade, menos intensa é a troca. Para este primeiro período, a densidade da rede $=0.84$. Pode-se considerar que a densidade da rede nesse período é alta, ou seja os atores estão bem conectados, o que facilita o fluxo de informações.

Diâmetro é a maior distância geodésica entre quaisquer pares de atores de uma rede. Sabemos que um caminho que conecta dois atores é a sequência de nós e laços que levam um a outro. A maior distância observada entre quaisquer pares de atores na rede é $=9$, portanto o diâmetro da rede neste período $=9$. 
Por fim, apresenta-se os blocos da rede no primeiro período. Foram identificados 21 blocos. Os dados sobre os blocos mostram em detalhes os arranjos ou conexões estabelecidas entre os atores da rede.

Tabela 16 - Blocos no Período de 1979 a 1984

\begin{tabular}{|c|c|c|}
\hline Blocos & & \\
\hline 1 & 277323 & 572717 \\
\hline 2 & 391304 & 858299 \\
\hline 3 & 549043 & 858299 \\
\hline 4 & 642405 & 858299 \\
\hline 5 & 119871 & 642405 \\
\hline 6 & 119871 & 452296 \\
\hline 7 & 452296 & 572717 \\
\hline 8 & 572717 & 815287 \\
\hline 9 & 469115 & 572717 \\
\hline 10 & 520744 & 757056 \\
\hline 11 & 469115 & 757056 \\
\hline 12 & 447873 & 967393 \\
\hline 13 & 469115 & 967393 \\
\hline 14 & 108955 & 469115 \\
\hline 15 & 379457 & 924867 \\
\hline 16 & 172661 & 924867 \\
\hline 17 & 196720 & 956406 \\
\hline 18 & 196720 & 976788 \\
\hline 19 & 231748 & 490507 \\
\hline 20 & 231748 & 895105 \\
\hline 21 & 365708 & 873256 \\
\hline
\end{tabular}

Nota: Tabela elaborada pela autora. 


\subsection{O segundo período escolhido para a análise da Rede Ipea foi: 1985 a 1994}

O Gráfico 26 traz o desenho da rede para este segundo período. Como visto, a rede mantém a característica de estar desconectada, ou seja, ainda não é possível estabelecer um caminho entre muitos nós e tantos outros. No primeiro período, a Rede do Ipea era formada por 5 (cinco) componentes, com 26 atores. Neste segundo período verificamos um crescimento grande da Rede Ipea. Contabilizamos agora 26 (vinte e seis) componentes, com 166 atores.

Um grande componente pode ser visto à direita, tendo o ator 244208 com maior grau nodal da Rede Ipea para este período, grau 18, compondo este grande subgrafo. Ao todo 12 atores ocupam posições centrais no maior componente ou subgrafo, que contém cerca de 75 atores. O segundo maior componente, com 19 atores, que consideramos um componente de tamanho médio, está localizado no topo do grafo, e possui dois atores centrais. $\mathrm{O}$ ator 695409, que tem o segundo maior grau nodal da rede, grau 9; e o ator 228253, que tem grau 8.

Outros cinco componentes estão dispersos no grafo 4, contendo entre 8 e 4 nós, totalizando 27 atores. Os 19 componentes restantes contêm 3 ou 2 nós. São as duplas de atores conectados, que formam díades e, os trios de atores conectados, que formam tríades. Ao todo foram encontrados na rede deste segundo período 13 díades e 6 tríades.

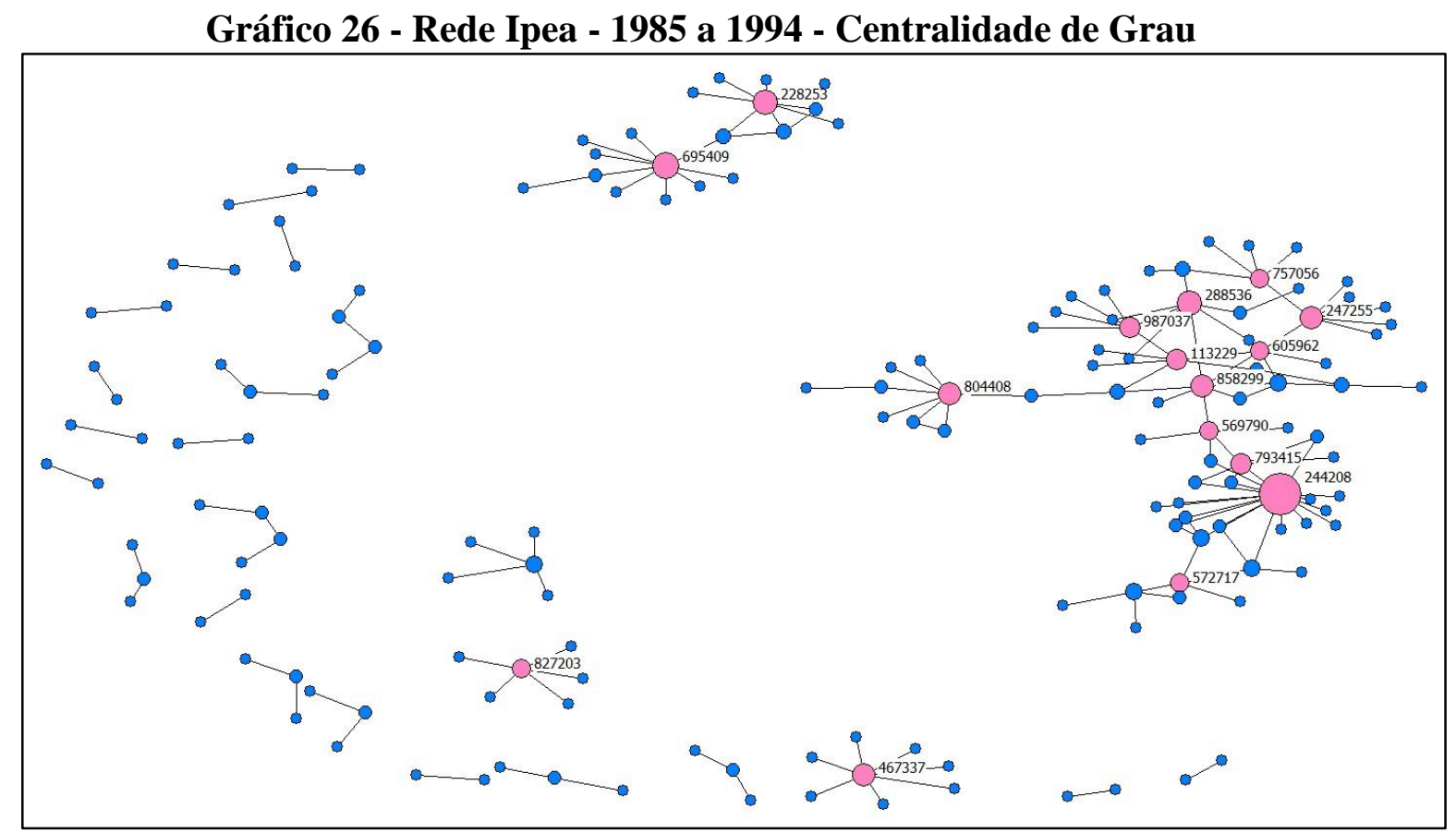

Nota: Elaboração da autora.

Selecionou-se 15 atores com maior grau nodal no período, que foram destacados no Gráfico 26 por meio da colocação das etiquetas com os códigos de identificação. Esses são os atores que possuem o maior grau nodal da rede para este segundo período e estão identificados com pontos cor de rosa. 
Como visto, o número de conexões nos fornece o grau de centralidade de um ator. Quanto mais centrais são os atores em uma rede, mais importantes são esses atores. $\mathrm{O}$ ator 244208 , com grau 18, é posto como o ator mais importante da rede neste período e está no maior componente da rede. O segundo ator mais importante da rede é o 695409, tem grau 9 e está localizado no subgrafo médio. Como pode-se ver, a diferença de conexões entre o $1^{\circ}$ ator com maior grau e o $2^{\circ}$, é exatamente o dobro de vínculos.

\section{Gráfico 27 - Componente Principal da Rede Ipea - 1985 a 1994}

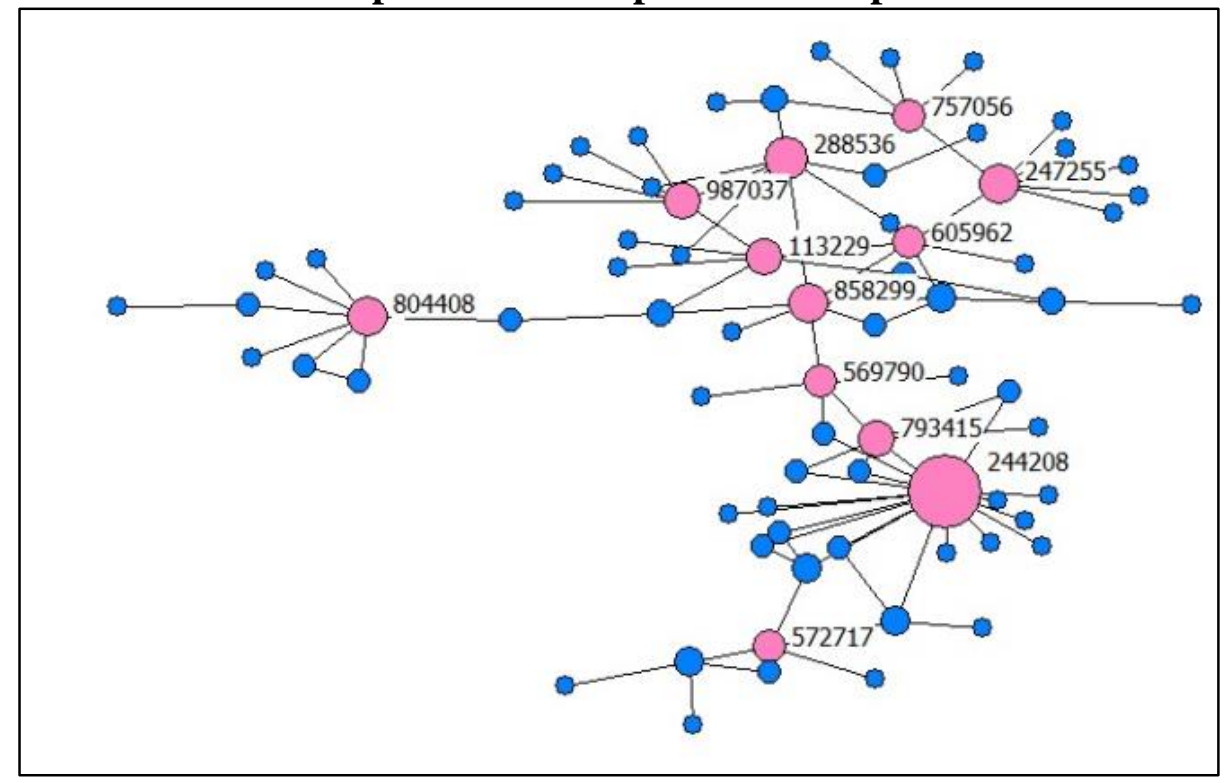

Nota: Elaboração da autora.

Os atores 228253 e 288536 têm ambos graus 8, e ocupam a $3^{\circ}$ e a $4^{\circ}$ posição de centralidade na rede, ou seja, possuem o terceiro e o quarto maior grau nodal ou número de laços com outros atores. Ambos estão localizados em subgrafos diferentes, sendo que o primeiro ator está no subgrafo médio, figura 11, e o segundo ator está no subgrafo principal, figura 10.

O componente médio, Gráfico 28, pode ser classificado como uma rede do tipo estrela dupla (Luna, 2010). As redes tipo estrela dupla possuem três nós centrais, os dois nós centrais de cada uma das redes, o 695409 e o 228253, e mais um nó central que conecta as duas redes estrela. Cada um dos atores centrais está ligado diretamente aos atores da sua rede e podemos dizer que possuem uma posição privilegiada em relação aos demais nós de cada rede estrela. O terceiro nó central, hub, conecta as duas redes.

\section{Gráfico 28 - Componente Médio da Rede Ipea - 1985 a 1994}

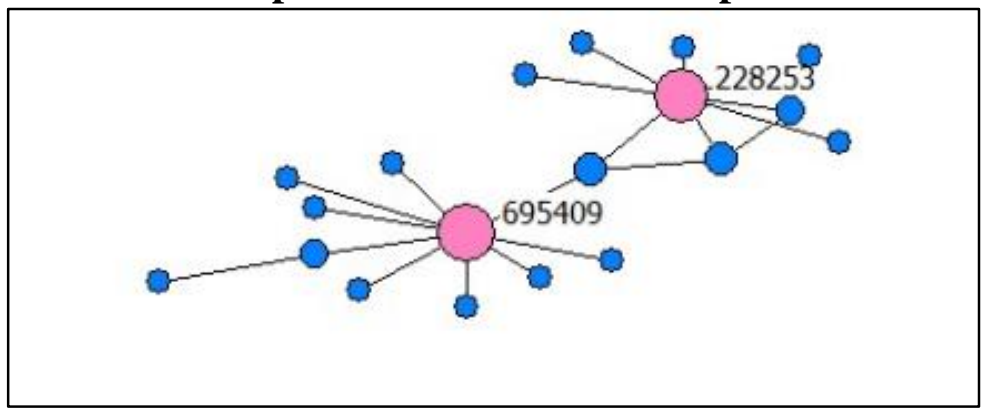

Nota: Elaboração da autora. 
As duas redes tipo estrela que compõem a rede estrela dupla, Gráfico 28, mostram uma pequena diferença entre si. A rede estrela que tem como o nó central o 695409 possui 9 atores que estão ligados apenas ao ator central e dependem do vínculo que possuem com o nó central para se manterem na rede. Na outra rede estrela, que tem como o nó central o 228253, percebe-se que três atores estabeleceram laços entre si, sendo um desses o nó central que liga as duas redes estrela.

Outros quatro atores, $247255,467337,804408$ e 858299 têm grau nodal igual a 7 . Todos pertencem ao subgrafo principal, exceto o 467337, que está em um subgrafo do tipo rede estrela, como podemos ver no Gráfico 29.

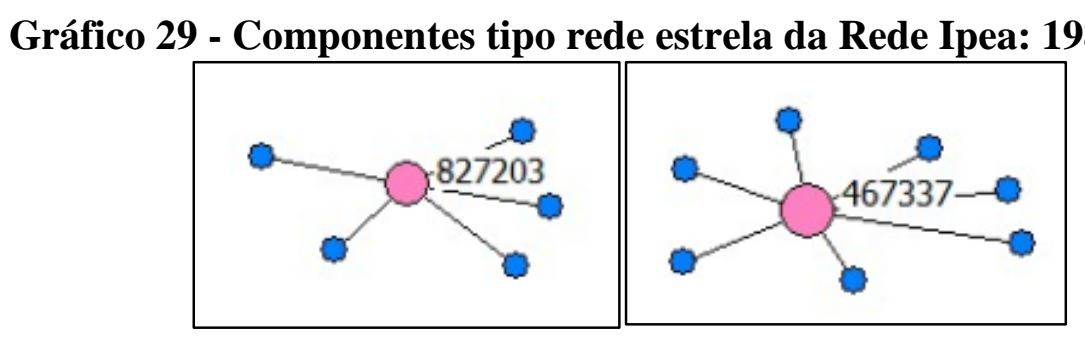

Nota: Elaboração da autora.

Como visto, outros cinco componentes estão dispersos no Gráfico 26 e totalizam 27 atores. Esses cinco componentes têm os seguintes tamanhos, do maior para o menor: 8 atores; 6 atores; 5 atores; 4 atores e 4 atores. Dentre estes, três formam redes tipo estrela, dos quais os dois maiores componentes formam cada um uma rede do tipo estrela. As duas redes tipo estrela, Gráfico 29, têm como nó central os atores 827203 e 467337.

Outros três atores, 113229, 793415e987037 têm grau nodal igual a 6. Para finalizar, os 4 últimos atores com identificação no grafo 4 possuem grau de centralidade 5, são eles: 569790, 572717, 605962 e 757056. Todos pertencem ao subgrafo principal, conforme pode-se verificar no Gráfico 27.

Relacionou-se na Tabela 17 as medidas de centralidade de todos os 166 atores da rede no segundo período. 
Tabela 17 - Centralidade de Grau dos Atores no Período de 1985 a 1994

\begin{tabular}{|c|c|c|c|c|c|c|c|c|}
\hline & Autor & Grau & & Autor & Grau & & Autor & Grau \\
\hline 1 & 244208 & 18 & 57 & 116298 & 1 & 112 & 519233 & 1 \\
\hline 2 & 695409 & 9 & 58 & 116674 & 1 & 113 & 547176 & 1 \\
\hline 3 & 228253 & 8 & 59 & 117719 & 1 & 114 & 553089 & 1 \\
\hline 4 & 288536 & 8 & 60 & 119871 & 1 & 115 & 557261 & 1 \\
\hline 5 & 247255 & 7 & 61 & 125561 & 1 & 116 & 558104 & 1 \\
\hline 6 & 467337 & 7 & 62 & 127181 & 1 & 117 & 562669 & 1 \\
\hline 7 & 804408 & 7 & 63 & 135051 & 1 & 118 & 565373 & 1 \\
\hline 8 & 858299 & 7 & 64 & 137526 & 1 & 119 & 569931 & 1 \\
\hline 9 & 113229 & 6 & 65 & 141716 & 1 & 120 & 584283 & 1 \\
\hline 10 & 793415 & 6 & 66 & 143598 & 1 & 121 & 587221 & 1 \\
\hline 11 & 987037 & 6 & 67 & 155022 & 1 & 122 & 606897 & 1 \\
\hline 12 & 569790 & 5 & 68 & 187768 & 1 & 123 & 610369 & 1 \\
\hline 13 & 572717 & 5 & 69 & 192416 & 1 & 124 & 612161 & 1 \\
\hline 14 & 605962 & 5 & 70 & 193060 & 1 & 125 & 615690 & 1 \\
\hline 15 & 757056 & 5 & 71 & 195078 & 1 & 126 & 647430 & 1 \\
\hline 16 & 827203 & 5 & 72 & 201056 & 1 & 127 & 650015 & 1 \\
\hline 17 & 277323 & 4 & 73 & 214803 & 1 & 128 & 655768 & 1 \\
\hline 18 & 365844 & 4 & 74 & 265761 & 1 & 129 & 656920 & 1 \\
\hline 19 & 524828 & 4 & 75 & 269148 & 1 & 130 & 695729 & 1 \\
\hline 20 & 559786 & 4 & 76 & 282432 & 1 & 131 & 702921 & 1 \\
\hline 21 & 873256 & 4 & 77 & 298090 & 1 & 132 & 704026 & 1 \\
\hline 22 & 101448 & 3 & 78 & 303934 & 1 & 133 & 704200 & 1 \\
\hline 23 & 172339 & 3 & 79 & 312015 & 1 & 134 & 709498 & 1 \\
\hline 24 & 368412 & 3 & 80 & 335764 & 1 & 135 & 713283 & 1 \\
\hline 25 & 520744 & 3 & 81 & 364655 & 1 & 136 & 723859 & 1 \\
\hline 26 & 577095 & 3 & 82 & 365708 & 1 & 137 & 732623 & 1 \\
\hline 27 & 116937 & 2 & 83 & 374265 & 1 & 138 & 741482 & 1 \\
\hline 28 & 173034 & 2 & 84 & 375681 & 1 & 139 & 748836 & 1 \\
\hline 29 & 230122 & 2 & 85 & 377382 & 1 & 140 & 757745 & 1 \\
\hline 30 & 231748 & 2 & 86 & 377900 & 1 & 141 & 758766 & 1 \\
\hline 31 & 249523 & 2 & 87 & 379562 & 1 & 142 & 786256 & 1 \\
\hline 32 & 273319 & 2 & 88 & 391402 & 1 & 143 & 813373 & 1 \\
\hline 33 & 278902 & 2 & 89 & 392761 & 1 & 144 & 839887 & 1 \\
\hline 34 & 278997 & 2 & 90 & 404800 & 1 & 145 & 845944 & 1 \\
\hline 35 & 287533 & 2 & 91 & 405531 & 1 & 146 & 857339 & 1 \\
\hline 36 & 379457 & 2 & 92 & 410898 & 1 & 147 & 870383 & 1 \\
\hline 37 & 411245 & 2 & 93 & 411859 & 1 & 148 & 882646 & 1 \\
\hline 38 & 430909 & 2 & 94 & 415392 & 1 & 149 & 884139 & 1 \\
\hline 39 & 476379 & 2 & 95 & 416680 & 1 & 150 & 888415 & 1 \\
\hline 40 & 589197 & 2 & 96 & 419447 & 1 & 151 & 893954 & 1 \\
\hline 41 & 599193 & 2 & 97 & 431669 & 1 & 152 & 895768 & 1 \\
\hline 42 & 600058 & 2 & 98 & 459631 & 1 & 153 & 906439 & 1 \\
\hline 43 & 648083 & 2 & 99 & 459972 & 1 & 154 & 909273 & 1 \\
\hline 44 & 726588 & 2 & 100 & 460847 & 1 & 155 & 910279 & 1 \\
\hline 45 & 752901 & 2 & 101 & 469115 & 1 & 156 & 916824 & 1 \\
\hline 46 & 863346 & 2 & 102 & 475755 & 1 & 157 & 927273 & 1 \\
\hline 47 & 908813 & 2 & 103 & 478780 & 1 & 158 & 929624 & 1 \\
\hline 48 & 923507 & 2 & 104 & 478824 & 1 & 159 & 949753 & 1 \\
\hline 49 & 936101 & 2 & 105 & 478956 & 1 & 160 & 961753 & 1 \\
\hline 50 & 948248 & 2 & 106 & 481457 & 1 & 161 & 968635 & 1 \\
\hline 51 & 962477 & 2 & 107 & 484872 & 1 & 162 & 972647 & 1 \\
\hline 52 & 976110 & 2 & 108 & 488071 & 1 & 163 & 976649 & 1 \\
\hline 53 & 981814 & 2 & 109 & 497562 & 1 & 164 & 987234 & 1 \\
\hline 54 & 100930 & 1 & 110 & 502447 & 1 & 165 & 993597 & 1 \\
\hline 55 & 103781 & 1 & 111 & 507257 & 1 & 166 & 993981 & 1 \\
\hline 56 & 110830 & 1 & & & & & & \\
\hline
\end{tabular}

Nota: Tabela elaborada pela autora. 
O Gráfico 30 destaca os atores de acordo com a medida de centralidade de intermediação ou betweenness. Como vimos, esta medida de centralidade está relacionada ao fato de um ator conectar subgrupos ou blocos, que de outro modo estariam desconectados. A centralidade de intermediação refere-se a questão de controle que os atores intermediários possuem sobre aqueles que dependem deles, uma vez que atores com alto grau de intermediação são pesquisadores mais bem posicionados na rede em relação aos demais.

Como visto, o Gráfico 30 apresenta os nós ou indivíduos com maior grau de intermediação na Rede Ipea de 1985 a 1994. De um total de 166 atores na rede, 37 atores possuem grau de intermediação. Como pode-se verificar, muitos atores que possuem alto grau nodal são também atores com alto grau de intermediação ou cutpoints.

\section{Gráfico 30 - Rede Ipea - 1985 a 1994 - Centralidade de Intermediação}

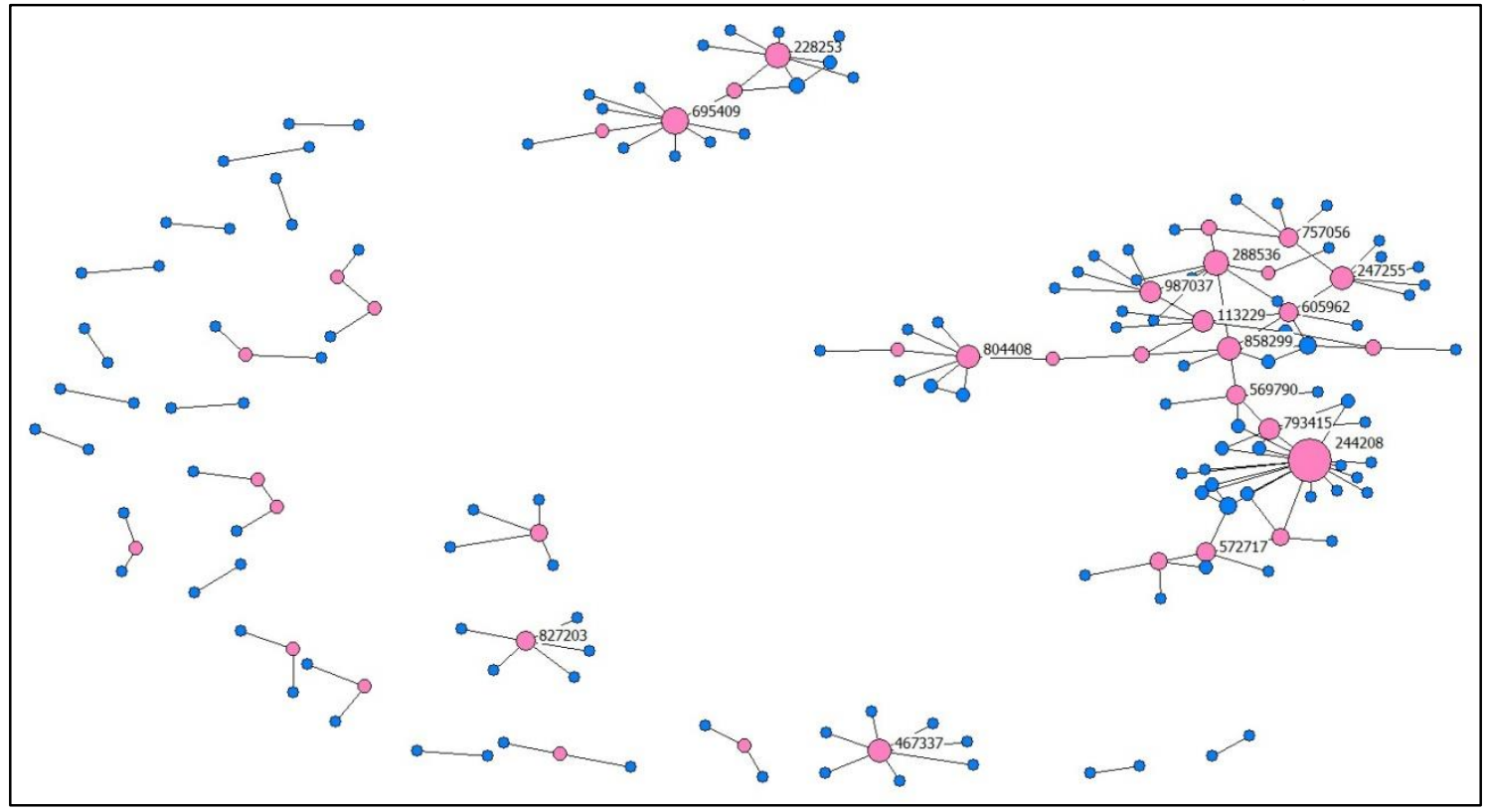

Nota: Elaboração da autora.

A centralidade de intermediação, betweenness centrality, em inglês, é uma medida baseada no controle potencial de um ator $\mathrm{X}$ sobre a interação de outros dois atores $\mathrm{Y}$ e $\mathrm{Z}$ da mesma rede. Representa, em um modelo de fluxo, quantas vezes o fluxo do tipo geodésico passa por X. Essa medida tem relação com a quantidade de recursos da rede que um ator controla, sendo que, se necessário, esse nó tem a capacidade de retirar esses recursos da rede. Em outras palavras, mede a quantidade de fluxos em uma rede que é controlada um nó determinado.Esses atores ligam atores na rede que de outra forma não estariam conectados. Borgatti (2005), Freeman, Borgatti e White (1999), Kadushkin (2004). 
Sabe-se então que neste segundo período 22,29\% dos atores fizeram a intermediação de mais relações de coautoria do que os demais autores. Pode-se considerar que os 37 atores com grau de intermediação igual a 1 , listados na tabela 5 abaixo, contribuem para que a rede seja menos fragmentada. Como mostra a Tabela 18, os cutpoints desempenham papéis de intermediação em todos os subgrafos da rede, com exceção das díades.

Tabela 18 - Centralidade de Intermediação dos atores no período de 1985 a 1994

\begin{tabular}{|c|c|c|}
\hline & Autor & Grau de intermediação \\
\hline 1 & 113229 & 1 \\
\hline 2 & 116937 & 1 \\
\hline 3 & 172339 & 1 \\
\hline 4 & 228253 & 1 \\
\hline 5 & 244208 & 1 \\
\hline 6 & 247255 & 1 \\
\hline 7 & 249523 & 1 \\
\hline 8 & 273319 & 1 \\
\hline 9 & 277323 & 1 \\
\hline 10 & 278902 & 1 \\
\hline 11 & 278997 & 1 \\
\hline 12 & 288536 & 1 \\
\hline 13 & 368412 & 1 \\
\hline 14 & 379457 & 1 \\
\hline 15 & 467337 & 1 \\
\hline 16 & 476379 & 1 \\
\hline 17 & 520744 & 1 \\
\hline 18 & 524828 & 1 \\
\hline 19 & 569790 & 1 \\
\hline 20 & 572717 & 1 \\
\hline 21 & 577095 & 1 \\
\hline 22 & 589197 & 1 \\
\hline 23 & 600058 & 1 \\
\hline 24 & 605962 & 1 \\
\hline 25 & 695409 & 1 \\
\hline 26 & 757056 & 1 \\
\hline 27 & 793415 & 1 \\
\hline 28 & 804408 & 1 \\
\hline 29 & 827203 & 1 \\
\hline 30 & 858299 & 1 \\
\hline 31 & 863346 & 1 \\
\hline 32 & 873256 & 1 \\
\hline 33 & 923507 & 1 \\
\hline 34 & 936101 & 1 \\
\hline 35 & 948248 & 1 \\
\hline 36 & 976110 & 1 \\
\hline 37 & 987037 & 1 \\
\hline
\end{tabular}

Nota: Tabela elaborada pela autora. 


\subsection{Análise da Rede Ipea: 1985 a 1994}

A rede deste segundo período tem 166 atores, ligados por 152 laços. $\mathrm{O}$ tamanho da rede no segundo período é 152 . No primeiro período a rede tinha 26 atores ligados por 21 laços.

Considerando as medidas de centralidade de todos os atores, infere-se algumas propriedades da rede. Ao somarmos os graus de todos os atores (316) e dividirmos pelo número de atores (166), teremos o grau médio da rede. A soma dos graus de todos os atores, tabela 4 , é $=316$. Se dividirmos 316 por 166 , teremos que o grau médio da rede no segundo período é $=1,90$. Comparado ao período anterior, houve um aumento no grau médio da rede, que era 1,61.

$\mathrm{Na}$ rede do segundo período, que possui 166 atores, podemos dizer que cada ator pode ter, no máximo, grau absoluto $=165$. Neste período, 165 é o número de laços possíveis para qualquer ator na rede. Em termos relativos, para saber o grau de centralidade de um ator, basta dividir seu número de laços pelo número de laços possíveis.

Densidade da rede é dada pelo quociente entre o número de ligações existentes (152), pelo número de ligações possíveis (165). A densidade retrata a potencialidade da rede em termos de fluxo de informações. Quanto maior a densidade, mais intensa é a troca de informações na rede e vice-versa. Para este segundo período, a densidade da rede $=0.92$. Podemos considerar que a densidade da rede nesse período é alta, ou seja os atores estão bem conectados, o que facilita o fluxo de informações. Comparado ao período anterior, houve um aumento da densidade da rede, que era 0,84 .

Por fim, apresenta-se os blocos da rede no segundo período. Foram identificados 115 blocos. Os dados sobre os blocos mostram em detalhes os arranjos ou conexões estabelecidas entre os atores da rede. As informações sobre os 115 blocos deste período estão disponíveis no apêndice 2. 
5.12 Comparação entre a rede de 1979 a 1984 e a rede de 1985 a 1994 ( $1^{\circ}$ período $x$ $2^{\circ}$ período)

Comparamos os dois períodos com o objetivo de saber se os principais atores identificados no primeiro período como sendo centrais, ou que tinham o maior grau nodal, se mantiveram na rede e se tiveram um aumento no grau nodal.

Constatamos que dos 26 atores que compunham a rede no primeiro período, 11 atores se mantiveram na rede. A Tabela 19 indica os atores que se mantiveram na rede e o grau nodal de cada um nos dois períodos.

Tabela 19 - Atores que Permaneceram na Rede do $1^{\circ}$ para $02^{\circ}$ período

\begin{tabular}{|c|c|c|}
\hline Atores & Grau_1o_período & Grau_2o_período \\
\hline 469115 & 4 & $\mathbf{1}$ \\
\hline 572717 & 4 & $\mathbf{5}$ \\
\hline 858299 & 3 & $\mathbf{7}$ \\
\hline 119871 & 2 & $\mathbf{1}$ \\
\hline 231748 & 2 & $\mathbf{2}$ \\
\hline 757056 & 2 & $\mathbf{5}$ \\
\hline 277323 & 1 & $\mathbf{4}$ \\
\hline 365708 & 1 & $\mathbf{1}$ \\
\hline 379457 & 1 & $\mathbf{2}$ \\
\hline 520744 & 1 & $\mathbf{3}$ \\
\hline 873256 & 1 & $\mathbf{4}$ \\
\hline
\end{tabular}

Nota: Tabela elaborada pela autora.

Dos 11 atores se mantiveram na rede, como pode-se observar, 7 (sete) atores tiveram o grau nodal aumentado. Outros 2 (dois) atores mantiveram o mesmo grau nodal e os 2 (dois) outros tiveram o grau de centralidade reduzido. O Gráfico 31 compara os dois conjuntos de valores para os atores que se mantiveram na rede. A soma dos graus destes atores no $1^{\circ}$ período é $=22$ e no $2^{\circ}$ período é $=35$.

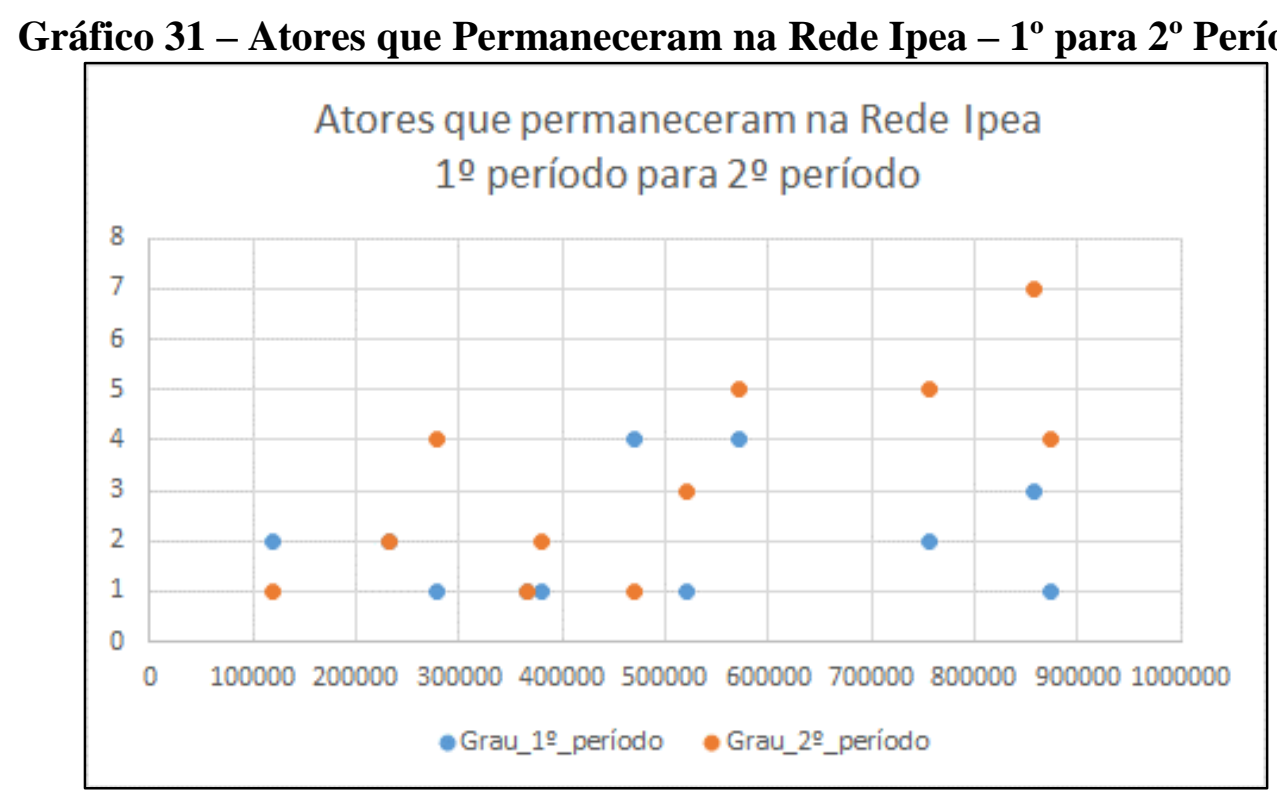

Nota: Elaboração da autora. 
Constatou-se que dos 26 atores que compunham a rede no primeiro período, 15 atores não se mantiveram na rede. A Tabela 20 e o Gráfico 32 indicam os atores que não se mantiveram na rede.

Tabela 20 - Atores que Não Permaneceram na Rede do $1^{\circ}$ para $02^{\circ}$ período

\begin{tabular}{|c|c|c|}
\hline Atores & Grau_1o & Grau_2o \\
\hline 196720 & 2 & 0 \\
\hline 452296 & 2 & 0 \\
\hline 642405 & 2 & 0 \\
\hline 924867 & 2 & 0 \\
\hline 967393 & 2 & 0 \\
\hline 108955 & 1 & 0 \\
\hline 172661 & 1 & 0 \\
\hline 391304 & 1 & 0 \\
\hline 447873 & 1 & 0 \\
\hline 490507 & 1 & 0 \\
\hline 549043 & 1 & 0 \\
\hline 815287 & 1 & 0 \\
\hline 895105 & 1 & 0 \\
\hline 956406 & 1 & 0 \\
\hline 976788 & 1 & 0 \\
\hline
\end{tabular}

Nota: Tabela elaborada pela autora.

O Gráfico 32 apresenta o gráfico de dispersão que compara os dois conjuntos de valores para os atores que não se mantiveram na rede.

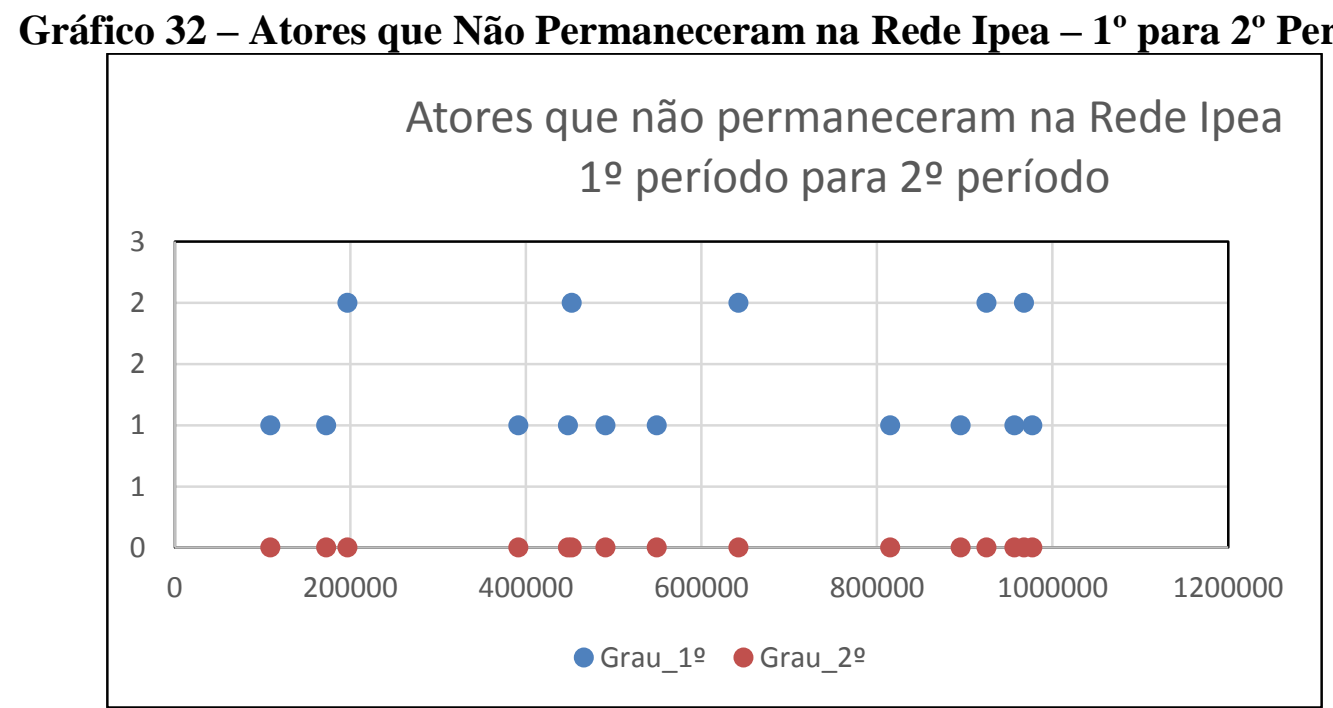

Nota: Elaboração da autora. 


\subsection{O terceiro período escolhido para a análise da Rede Ipea foi: 1995 a 2010}

O Gráfico 33 é uma representação gráfica para a rede no terceiro período. Exatamente neste período a rede assume a mesma representação gráfica da rede nos 37 anos. A partir deste período, a Rede Ipea assumiu seu desenho gráfico que mantém. Podemos ver um grande componente e muitos outros que estão representados nesta nuvem superior compacta. Percebe-se claramente que a rede é do tipo sociocêntrica, típica rede institucional que se desenvolve em função de seus membros centrais.

O tamanho da rede cresceu muito em comparação ao segundo período. No primeiro período, a Rede do Ipea era composta por 26 atores, no segundo contabilizamos 166 atores. Neste terceiro período estudado, a rede totaliza 712 atores.

No segundo período o ator com maior grau de centralidade é o 244208 , que estabeleceu o maior número de vínculos de coautoria, atingindo no segundo período, de 1985 a 1994 , grau 18, o dobro do segundo ator, em valores absolutos. No terceiro período o ator 244208 ainda se mantém como o maior ator da rede, e possui grau nodal igual a 32.

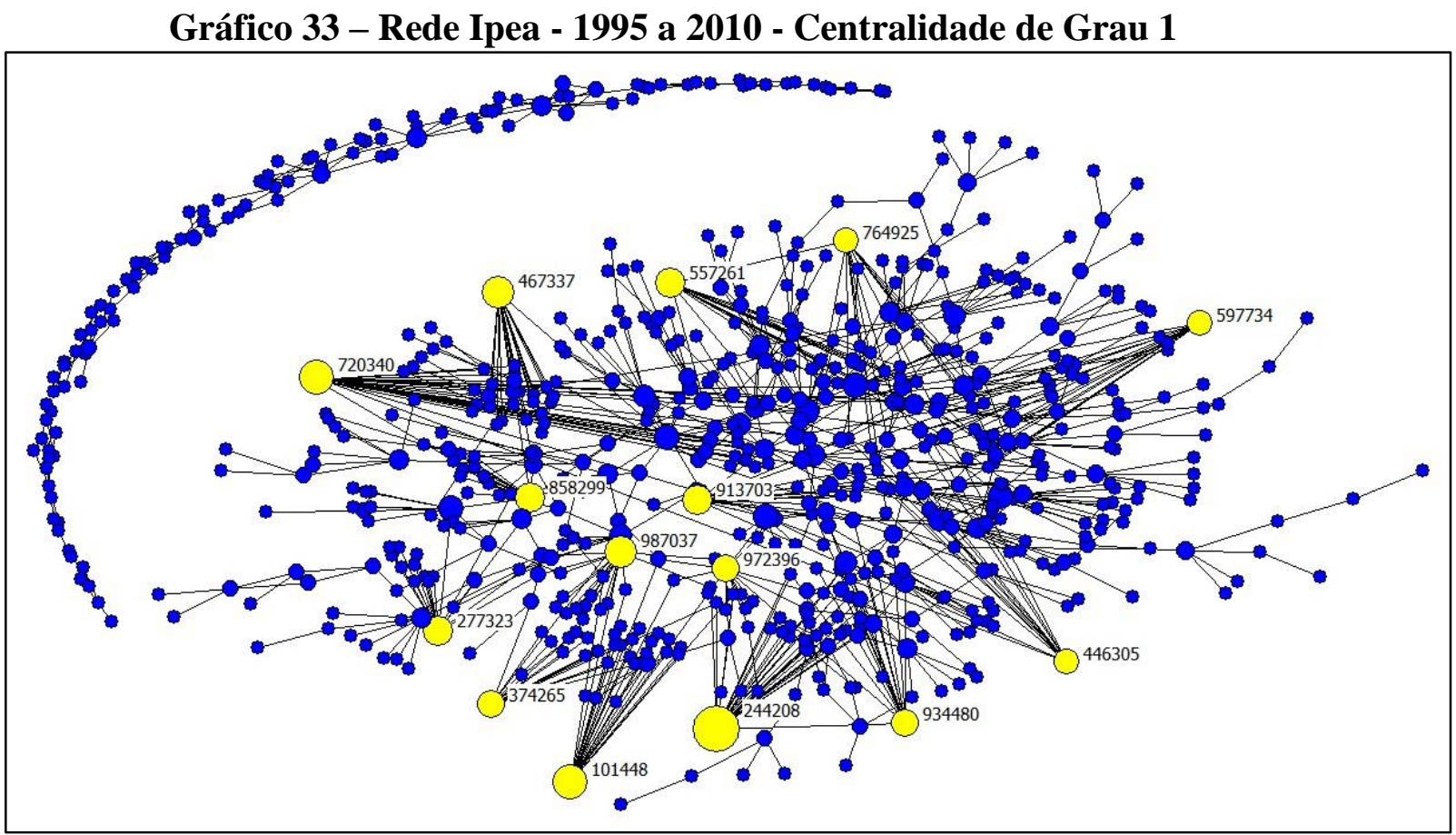

Nota: Elaboração da autora.

O ator 720340 é o segundo ator principal da rede neste período em função da sua posição central. É apontado como o segundo mais importante e chama a atenção, pois ao contrário do primeiro ator, que já era o principal ator no período anterior, este surge na rede neste período com grau de centralidade igual a 21. O terceiro ator mais importante é o 101448, que possui grau nodal igual a 20, apenas uma ligação a menos que o segundo, mas assim como o primeiro ator, o terceiro já fazia parte da rede no período anterior, com grau 3.

Utilizou-se para este período, o maior período estudado dentre os quatro escolhidos, dois grafos para centralidade do grau e dois grafos para a centralidade de intermediação. $\mathrm{O}$ 
Gráfico 33, traz os 15 atores com maior grau nodal destacados pelo tamanho dos nós que os representam. O primeiro grafo sofreu algumas alterações quanto à posição desses atores, para que fosse possível a identificação com as etiquetas de códigos dos principais nós. No Gráfico 34, as posições dos principais atores foram pouco alteradas e mostramos todos os nós do mesmo tamanho. As etiquetas identificam os 29 principais atores da rede segundo o grau de centralidade.

\section{Gráfico 34 - Rede Ipea - 1995 a 2010 - Centralidade de Grau - 2}

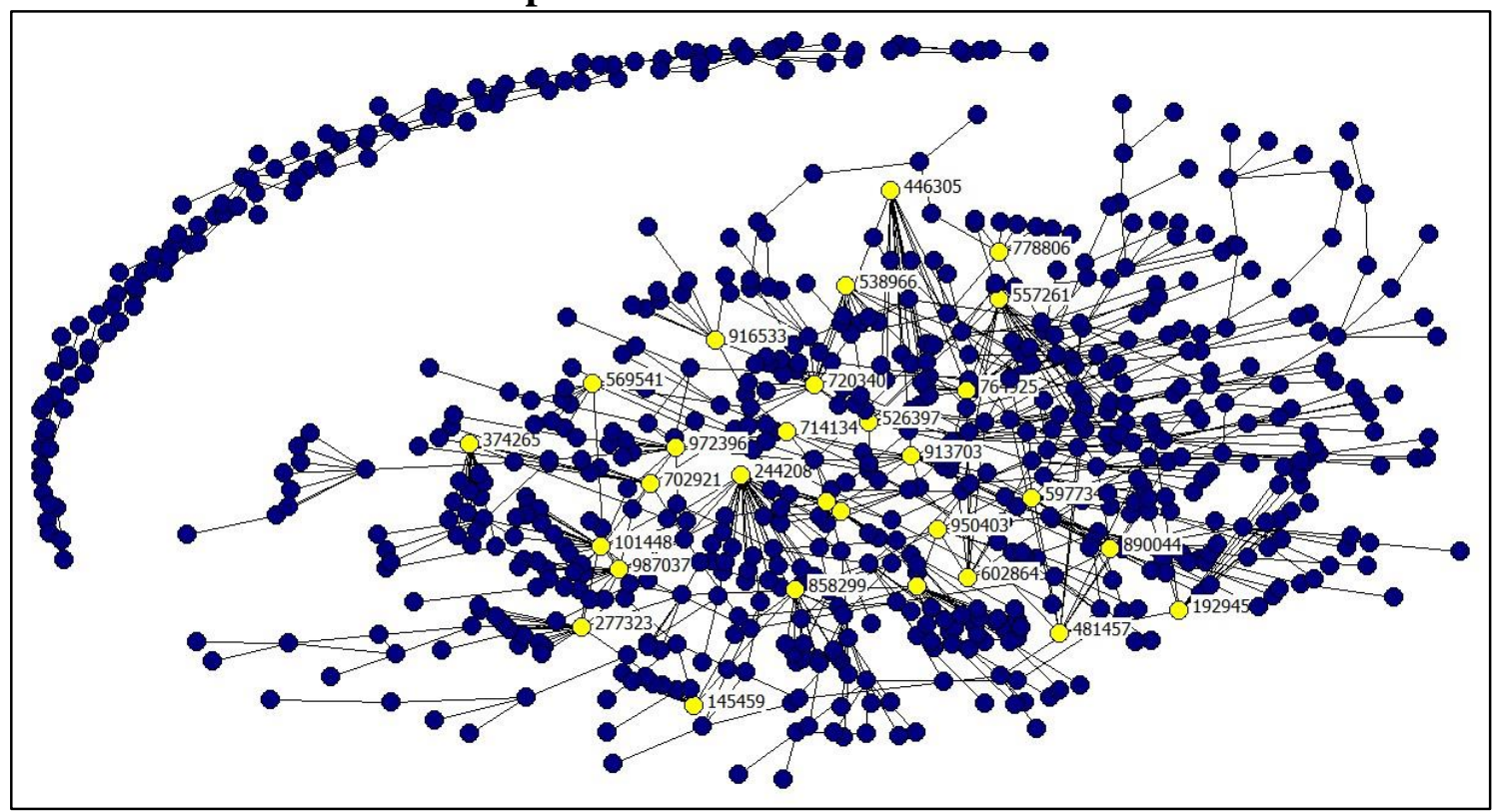

Nota: Elaboração da autora.

Muitos atores assumiram neste período posições centrais na rede em função das relações de coautoria que estabeleceram. Os 29 atores acima destacados possuem grau de centralidade absoluto que variou de 32 a 9. Relacionamos na Tabela 21 abaixo as medidas de centralidade de todos os 712 atores da rede no terceiro período. 
Tabela 21 - Centralidade de Grau dos Atores no Período de 1995 a 2010

\begin{tabular}{|c|c|c|c|c|c|c|c|c|}
\hline & Ator & Grau & & Ator & Grau & & Ator & Grau \\
\hline 1 & 244208 & 32 & 51 & 601830 & 6 & 101 & 886230 & 4 \\
\hline 2 & 720340 & 21 & 52 & 623856 & 6 & 102 & 922121 & 4 \\
\hline 3 & 101448 & 20 & 53 & 667688 & 6 & 103 & 927278 & 4 \\
\hline 4 & 467337 & 19 & 54 & 670853 & 6 & 104 & 938626 & 4 \\
\hline 5 & 987037 & 18 & 55 & 730987 & 6 & 105 & 939878 & 4 \\
\hline 6 & 277323 & 17 & 56 & 830622 & 6 & 106 & 943547 & 4 \\
\hline 7 & 913703 & 17 & 57 & 834593 & 6 & 107 & 955578 & 4 \\
\hline 8 & 557261 & 16 & 58 & 986373 & 6 & 108 & 967301 & 4 \\
\hline 9 & 858299 & 16 & 59 & 106525 & 5 & 109 & 986849 & 4 \\
\hline 10 & 374265 & 14 & 60 & 210945 & 5 & 110 & 991698 & 4 \\
\hline 11 & 934480 & 14 & 61 & 223814 & 5 & 111 & 113844 & 3 \\
\hline 12 & 972396 & 14 & 62 & 226329 & 5 & 112 & 115908 & 3 \\
\hline 13 & 446305 & 13 & 63 & 239355 & 5 & 113 & 125659 & 3 \\
\hline 14 & 597734 & 13 & 64 & 347180 & 5 & 114 & 129565 & 3 \\
\hline 15 & 764925 & 13 & 65 & 498214 & 5 & 115 & 167673 & 3 \\
\hline 16 & 714134 & 12 & 66 & 513619 & 5 & 116 & 173034 & 3 \\
\hline 17 & 145459 & 11 & 67 & 551725 & 5 & 117 & 201056 & 3 \\
\hline 18 & 192945 & 11 & 68 & 579356 & 5 & 118 & 208566 & 3 \\
\hline 19 & 538966 & 11 & 69 & 690817 & 5 & 119 & 220220 & 3 \\
\hline 20 & 890044 & 11 & 70 & 695567 & 5 & 120 & 226570 & 3 \\
\hline 21 & 950403 & 11 & 71 & 877046 & 5 & 121 & 228317 & 3 \\
\hline 22 & 569541 & 10 & 72 & 936101 & 5 & 122 & 234372 & 3 \\
\hline 23 & 602864 & 10 & 73 & 154677 & 4 & 123 & 240637 & 3 \\
\hline 24 & 841791 & 10 & 74 & 174769 & 4 & 124 & 244282 & 3 \\
\hline 25 & 481457 & 9 & 75 & 180840 & 4 & 125 & 278902 & 3 \\
\hline 26 & 526397 & 9 & 76 & 194293 & 4 & 126 & 282172 & 3 \\
\hline 27 & 702921 & 9 & 77 & 206032 & 4 & 127 & 310500 & 3 \\
\hline 28 & 778806 & 9 & 78 & 242135 & 4 & 128 & 315243 & 3 \\
\hline 29 & 916533 & 9 & 79 & 255976 & 4 & 129 & 316462 & 3 \\
\hline 30 & 524828 & 8 & 80 & 281011 & 4 & 130 & 365708 & 3 \\
\hline 31 & 572717 & 8 & 81 & 320941 & 4 & 131 & 368412 & 3 \\
\hline 32 & 605962 & 8 & 82 & 342088 & 4 & 132 & 372709 & 3 \\
\hline 33 & 636334 & 8 & 83 & 373711 & 4 & 133 & 403559 & 3 \\
\hline 34 & 919857 & 8 & 84 & 437260 & 4 & 134 & 404403 & 3 \\
\hline 35 & 946122 & 8 & 85 & 555519 & 4 & 135 & 409000 & 3 \\
\hline 36 & 976649 & 8 & 86 & 565373 & 4 & 136 & 424027 & 3 \\
\hline 37 & 136286 & 7 & 87 & 590710 & 4 & 137 & 438227 & 3 \\
\hline 38 & 235857 & 7 & 88 & 607687 & 4 & 138 & 443261 & 3 \\
\hline 39 & 301347 & 7 & 89 & 640265 & 4 & 139 & 446668 & 3 \\
\hline 40 & 327991 & 7 & 90 & 667182 & 4 & 140 & 451276 & 3 \\
\hline 41 & 449152 & 7 & 91 & 690274 & 4 & 141 & 502447 & 3 \\
\hline 42 & 681599 & 7 & 92 & 703946 & 4 & 142 & 515857 & 3 \\
\hline 43 & 742671 & 7 & 93 & 758766 & 4 & 143 & 534938 & 3 \\
\hline 44 & 770131 & 7 & 94 & 766189 & 4 & 144 & 570846 & 3 \\
\hline 45 & 855367 & 7 & 95 & 780249 & 4 & 145 & 606897 & 3 \\
\hline 46 & 946030 & 7 & 96 & 793748 & 4 & 146 & 665704 & 3 \\
\hline 47 & 228253 & 6 & 97 & 808588 & 4 & 147 & 672205 & 3 \\
\hline 48 & 270937 & 6 & 98 & 841404 & 4 & 148 & 687825 & 3 \\
\hline 49 & 303934 & 6 & 99 & 880316 & 4 & 149 & 695409 & 3 \\
\hline 50 & 490550 & 6 & 100 & 881065 & 4 & 150 & 722125 & 3 \\
\hline
\end{tabular}




\begin{tabular}{|c|c|c|c|c|c|c|c|c|}
\hline & Ator & Grau & & Ator & Grau & & Ator & Grau \\
\hline 151 & 744353 & 3 & 201 & 345776 & 2 & 251 & 746710 & 2 \\
\hline 152 & 756857 & 3 & 202 & 353643 & 2 & 252 & 750281 & 2 \\
\hline 153 & 757305 & 3 & 203 & 353889 & 2 & 253 & 759397 & 2 \\
\hline 154 & 772169 & 3 & 204 & 375064 & 2 & 254 & 760607 & 2 \\
\hline 155 & 779107 & 3 & 205 & 376251 & 2 & 255 & 763587 & 2 \\
\hline 156 & 781167 & 3 & 206 & 379562 & 2 & 256 & 771127 & 2 \\
\hline 157 & 788948 & 3 & 207 & 394119 & 2 & 257 & 784011 & 2 \\
\hline 158 & 808647 & 3 & 208 & 398798 & 2 & 258 & 788978 & 2 \\
\hline 159 & 842392 & 3 & 209 & 403577 & 2 & 259 & 790379 & 2 \\
\hline 160 & 854889 & 3 & 210 & 405878 & 2 & 260 & 796925 & 2 \\
\hline 161 & 860164 & 3 & 211 & 413809 & 2 & 261 & 800570 & 2 \\
\hline 162 & 879460 & 3 & 212 & 415043 & 2 & 262 & 801498 & 2 \\
\hline 163 & 972647 & 3 & 213 & 425435 & 2 & 263 & 812238 & 2 \\
\hline 164 & 979287 & 3 & 214 & 426824 & 2 & 264 & 815929 & 2 \\
\hline 165 & 984357 & 3 & 215 & 427755 & 2 & 265 & 843320 & 2 \\
\hline 166 & 103308 & 2 & 216 & 479241 & 2 & 266 & 843447 & 2 \\
\hline 167 & 105210 & 2 & 217 & 482414 & 2 & 267 & 863644 & 2 \\
\hline 168 & 108214 & 2 & 218 & 486149 & 2 & 268 & 867460 & 2 \\
\hline 169 & 113726 & 2 & 219 & 493954 & 2 & 269 & 875506 & 2 \\
\hline 170 & 119871 & 2 & 220 & 495566 & 2 & 270 & 888682 & 2 \\
\hline 171 & 151092 & 2 & 221 & 510229 & 2 & 271 & 897731 & 2 \\
\hline 172 & 157074 & 2 & 222 & 515289 & 2 & 272 & 909456 & 2 \\
\hline 173 & 165155 & 2 & 223 & 523567 & 2 & 273 & 918898 & 2 \\
\hline 174 & 168696 & 2 & 224 & 527418 & 2 & 274 & 927784 & 2 \\
\hline 175 & 172836 & 2 & 225 & 535505 & 2 & 275 & 941310 & 2 \\
\hline 176 & 175598 & 2 & 226 & 539240 & 2 & 276 & 943325 & 2 \\
\hline 177 & 188784 & 2 & 227 & 549265 & 2 & 277 & 945083 & 2 \\
\hline 178 & 192416 & 2 & 228 & 565446 & 2 & 278 & 947367 & 2 \\
\hline 179 & 193060 & 2 & 229 & 566812 & 2 & 279 & 962477 & 2 \\
\hline 180 & 209132 & 2 & 230 & 590939 & 2 & 280 & 984582 & 2 \\
\hline 181 & 210212 & 2 & 231 & 591547 & 2 & 281 & 986022 & 2 \\
\hline 182 & 217701 & 2 & 232 & 593077 & 2 & 282 & 987058 & 2 \\
\hline 183 & 236551 & 2 & 233 & 597311 & 2 & 283 & 102305 & 1 \\
\hline 184 & 240208 & 2 & 234 & 614790 & 2 & 284 & 102965 & 1 \\
\hline 185 & 245783 & 2 & 235 & 615690 & 2 & 285 & 107316 & 1 \\
\hline 186 & 258152 & 2 & 236 & 616379 & 2 & 286 & 107917 & 1 \\
\hline 187 & 261976 & 2 & 237 & 629693 & 2 & 287 & 108762 & 1 \\
\hline 188 & 272213 & 2 & 238 & 630341 & 2 & 288 & 109151 & 1 \\
\hline 189 & 281259 & 2 & 239 & 637923 & 2 & 289 & 110512 & 1 \\
\hline 190 & 285512 & 2 & 240 & 644032 & 2 & 290 & 111675 & 1 \\
\hline 191 & 288536 & 2 & 241 & 644081 & 2 & 291 & 112468 & 1 \\
\hline 192 & 289128 & 2 & 242 & 644623 & 2 & 292 & 112538 & 1 \\
\hline 193 & 291479 & 2 & 243 & 645079 & 2 & 293 & 113469 & 1 \\
\hline 194 & 294073 & 2 & 244 & 671089 & 2 & 294 & 113853 & 1 \\
\hline 195 & 304958 & 2 & 245 & 675846 & 2 & 295 & 114453 & 1 \\
\hline 196 & 314489 & 2 & 246 & 677661 & 2 & 296 & 116298 & 1 \\
\hline 197 & 317682 & 2 & 247 & 701064 & 2 & 297 & 116413 & 1 \\
\hline 198 & 317790 & 2 & 248 & 703903 & 2 & 298 & 117021 & 1 \\
\hline 199 & 343384 & 2 & 249 & 709498 & 2 & 299 & 119196 & 1 \\
\hline 200 & 345724 & 2 & 250 & 720092 & 2 & 300 & 123188 & 1 \\
\hline
\end{tabular}




\begin{tabular}{|c|c|c|c|c|c|c|c|c|}
\hline & Ator & Grau & & Ator & Grau & & Ator & Grau \\
\hline 301 & 130284 & 1 & 351 & 240387 & 1 & 401 & 345773 & 1 \\
\hline 302 & 137573 & 1 & 352 & 249484 & 1 & 402 & 347804 & 1 \\
\hline 303 & 140563 & 1 & 353 & 249536 & 1 & 403 & 350210 & 1 \\
\hline 304 & 145551 & 1 & 354 & 253796 & 1 & 404 & 350989 & 1 \\
\hline 305 & 150514 & 1 & 355 & 254477 & 1 & 405 & 351514 & 1 \\
\hline 306 & 151932 & 1 & 356 & 254817 & 1 & 406 & 351854 & 1 \\
\hline 307 & 151984 & 1 & 357 & 258623 & 1 & 407 & 352712 & 1 \\
\hline 308 & 158658 & 1 & 358 & 264364 & 1 & 408 & 353327 & 1 \\
\hline 309 & 159550 & 1 & 359 & 265396 & 1 & 409 & 353389 & 1 \\
\hline 310 & 161059 & 1 & 360 & 265761 & 1 & 410 & 357202 & 1 \\
\hline 311 & 162224 & 1 & 361 & 268096 & 1 & 411 & 362205 & 1 \\
\hline 312 & 163028 & 1 & 362 & 268400 & 1 & 412 & 362728 & 1 \\
\hline 313 & 163032 & 1 & 363 & 269059 & 1 & 413 & 366259 & 1 \\
\hline 314 & 163952 & 1 & 364 & 271640 & 1 & 414 & 372860 & 1 \\
\hline 315 & 167362 & 1 & 365 & 272068 & 1 & 415 & 373615 & 1 \\
\hline 316 & 169397 & 1 & 366 & 273477 & 1 & 416 & 378633 & 1 \\
\hline 317 & 169642 & 1 & 367 & 273786 & 1 & 417 & 379844 & 1 \\
\hline 318 & 171257 & 1 & 368 & 274518 & 1 & 418 & 381198 & 1 \\
\hline 319 & 174154 & 1 & 369 & 275871 & 1 & 419 & 384305 & 1 \\
\hline 320 & 175898 & 1 & 370 & 277936 & 1 & 420 & 386578 & 1 \\
\hline 321 & 180332 & 1 & 371 & 278175 & 1 & 421 & 392223 & 1 \\
\hline 322 & 184130 & 1 & 372 & 282124 & 1 & 422 & 393346 & 1 \\
\hline 323 & 184217 & 1 & 373 & 282529 & 1 & 423 & 393984 & 1 \\
\hline 324 & 186251 & 1 & 374 & 283257 & 1 & 424 & 396091 & 1 \\
\hline 325 & 188131 & 1 & 375 & 286833 & 1 & 425 & 396226 & 1 \\
\hline 326 & 188677 & 1 & 376 & 287240 & 1 & 426 & 397922 & 1 \\
\hline 327 & 191086 & 1 & 377 & 290924 & 1 & 427 & 401542 & 1 \\
\hline 328 & 191642 & 1 & 378 & 291858 & 1 & 428 & 406609 & 1 \\
\hline 329 & 198012 & 1 & 379 & 292242 & 1 & 429 & 410637 & 1 \\
\hline 330 & 198606 & 1 & 380 & 293427 & 1 & 430 & 411859 & 1 \\
\hline 331 & 199640 & 1 & 381 & 295009 & 1 & 431 & 413271 & 1 \\
\hline 332 & 202261 & 1 & 382 & 296755 & 1 & 432 & 413843 & 1 \\
\hline 333 & 204043 & 1 & 383 & 297500 & 1 & 433 & 415392 & 1 \\
\hline 334 & 204278 & 1 & 384 & 297879 & 1 & 434 & 417343 & 1 \\
\hline 335 & 205411 & 1 & 385 & 306956 & 1 & 435 & 419447 & 1 \\
\hline 336 & 205444 & 1 & 386 & 307229 & 1 & 436 & 419624 & 1 \\
\hline 337 & 207627 & 1 & 387 & 309561 & 1 & 437 & 420415 & 1 \\
\hline 338 & 207776 & 1 & 388 & 310540 & 1 & 438 & 421131 & 1 \\
\hline 339 & 211675 & 1 & 389 & 312318 & 1 & 439 & 421230 & 1 \\
\hline 340 & 212868 & 1 & 390 & 314726 & 1 & 440 & 421287 & 1 \\
\hline 341 & 213498 & 1 & 391 & 315526 & 1 & 441 & 423465 & 1 \\
\hline 342 & 219371 & 1 & 392 & 319080 & 1 & 442 & 424769 & 1 \\
\hline 343 & 219879 & 1 & 393 & 319656 & 1 & 443 & 425134 & 1 \\
\hline 344 & 222079 & 1 & 394 & 322294 & 1 & 444 & 425432 & 1 \\
\hline 345 & 224200 & 1 & 395 & 328310 & 1 & 445 & 425888 & 1 \\
\hline 346 & 224591 & 1 & 396 & 328930 & 1 & 446 & 426038 & 1 \\
\hline 347 & 226617 & 1 & 397 & 329285 & 1 & 447 & 427922 & 1 \\
\hline 348 & 227503 & 1 & 398 & 337125 & 1 & 448 & 432286 & 1 \\
\hline 349 & 229694 & 1 & 399 & 337449 & 1 & 449 & 435626 & 1 \\
\hline 350 & 231781 & 1 & 400 & 338820 & 1 & 450 & 438296 & 1 \\
\hline
\end{tabular}




\begin{tabular}{|c|c|c|c|c|c|c|c|c|}
\hline & Ator & Grau & & Ator & Grau & & Ator & Grau \\
\hline 451 & 438704 & 1 & 501 & 514123 & 1 & 551 & 627788 & 1 \\
\hline 452 & 439292 & 1 & 502 & 515892 & 1 & 552 & 628097 & 1 \\
\hline 453 & 439819 & 1 & 503 & 519435 & 1 & 553 & 629656 & 1 \\
\hline 454 & 439870 & 1 & 504 & 520744 & 1 & 554 & 629855 & 1 \\
\hline 455 & 440316 & 1 & 505 & 521334 & 1 & 555 & 631238 & 1 \\
\hline 456 & 441139 & 1 & 506 & 526313 & 1 & 556 & 631962 & 1 \\
\hline 457 & 441794 & 1 & 507 & 527376 & 1 & 557 & 637995 & 1 \\
\hline 458 & 447081 & 1 & 508 & 527648 & 1 & 558 & 644889 & 1 \\
\hline 459 & 448201 & 1 & 509 & 533109 & 1 & 559 & 646197 & 1 \\
\hline 460 & 450368 & 1 & 510 & 538765 & 1 & 560 & 649410 & 1 \\
\hline 461 & 451184 & 1 & 511 & 539967 & 1 & 561 & 649954 & 1 \\
\hline 462 & 452425 & 1 & 512 & 540115 & 1 & 562 & 650015 & 1 \\
\hline 463 & 452595 & 1 & 513 & 543037 & 1 & 563 & 650995 & 1 \\
\hline 464 & 452987 & 1 & 514 & 543683 & 1 & 564 & 653429 & 1 \\
\hline 465 & 453729 & 1 & 515 & 543960 & 1 & 565 & 657142 & 1 \\
\hline 466 & 454931 & 1 & 516 & 547100 & 1 & 566 & 659257 & 1 \\
\hline 467 & 456499 & 1 & 517 & 548772 & 1 & 567 & 659353 & 1 \\
\hline 468 & 459319 & 1 & 518 & 552764 & 1 & 568 & 663543 & 1 \\
\hline 469 & 459600 & 1 & 519 & 553074 & 1 & 569 & 673605 & 1 \\
\hline 470 & 460521 & 1 & 520 & 555177 & 1 & 570 & 676346 & 1 \\
\hline 471 & 460840 & 1 & 521 & 555629 & 1 & 571 & 677832 & 1 \\
\hline 472 & 461216 & 1 & 522 & 559786 & 1 & 572 & 681414 & 1 \\
\hline 473 & 463216 & 1 & 523 & 561738 & 1 & 573 & 682283 & 1 \\
\hline 474 & 463447 & 1 & 524 & 563015 & 1 & 574 & 683483 & 1 \\
\hline 475 & 464784 & 1 & 525 & 563300 & 1 & 575 & 684554 & 1 \\
\hline 476 & 466272 & 1 & 526 & 566319 & 1 & 576 & 686155 & 1 \\
\hline 477 & 467570 & 1 & 527 & 572819 & 1 & 577 & 688185 & 1 \\
\hline 478 & 473242 & 1 & 528 & 572955 & 1 & 578 & 688349 & 1 \\
\hline 479 & 475610 & 1 & 529 & 574991 & 1 & 579 & 689598 & 1 \\
\hline 480 & 475755 & 1 & 530 & 577095 & 1 & 580 & 696589 & 1 \\
\hline 481 & 476919 & 1 & 531 & 577811 & 1 & 581 & 696729 & 1 \\
\hline 482 & 477637 & 1 & 532 & 578999 & 1 & 582 & 699035 & 1 \\
\hline 483 & 478338 & 1 & 533 & 579171 & 1 & 583 & 699443 & 1 \\
\hline 484 & 486127 & 1 & 534 & 581109 & 1 & 584 & 704283 & 1 \\
\hline 485 & 486513 & 1 & 535 & 584574 & 1 & 585 & 709240 & 1 \\
\hline 486 & 487183 & 1 & 536 & 586859 & 1 & 586 & 711730 & 1 \\
\hline 487 & 487293 & 1 & 537 & 587143 & 1 & 587 & 713283 & 1 \\
\hline 488 & 491662 & 1 & 538 & 588580 & 1 & 588 & 720142 & 1 \\
\hline 489 & 493028 & 1 & 539 & 591431 & 1 & 589 & 720845 & 1 \\
\hline 490 & 493244 & 1 & 540 & 591735 & 1 & 590 & 723107 & 1 \\
\hline 491 & 493322 & 1 & 541 & 594283 & 1 & 591 & 723561 & 1 \\
\hline 492 & 493802 & 1 & 542 & 594995 & 1 & 592 & 724393 & 1 \\
\hline 493 & 496283 & 1 & 543 & 595101 & 1 & 593 & 724605 & 1 \\
\hline 494 & 497220 & 1 & 544 & 600106 & 1 & 594 & 730581 & 1 \\
\hline 495 & 503428 & 1 & 545 & 606261 & 1 & 595 & 735294 & 1 \\
\hline 496 & 507554 & 1 & 546 & 606476 & 1 & 596 & 735341 & 1 \\
\hline 497 & 509591 & 1 & 547 & 608731 & 1 & 597 & 735452 & 1 \\
\hline 498 & 510736 & 1 & 548 & 609812 & 1 & 598 & 735783 & 1 \\
\hline 499 & 511167 & 1 & 549 & 614896 & 1 & 599 & 736816 & 1 \\
\hline 500 & 513710 & 1 & 550 & 626042 & 1 & 600 & 739608 & 1 \\
\hline
\end{tabular}




\begin{tabular}{|c|c|c|c|c|c|c|c|c|}
\hline & Ator & Grau & & Ator & Grau & & Ator & Grau \\
\hline 601 & 739639 & 1 & 651 & 852266 & 1 & 701 & 964148 & 1 \\
\hline 602 & 740107 & 1 & 652 & 858051 & 1 & 702 & 964358 & 1 \\
\hline 603 & 747496 & 1 & 653 & 860020 & 1 & 703 & 965527 & 1 \\
\hline 604 & 749376 & 1 & 654 & 861341 & 1 & 704 & 966730 & 1 \\
\hline 605 & 750768 & 1 & 655 & 866952 & 1 & 705 & 967643 & 1 \\
\hline 606 & 751174 & 1 & 656 & 867154 & 1 & 706 & 976788 & 1 \\
\hline 607 & 752165 & 1 & 657 & 869302 & 1 & 707 & 977072 & 1 \\
\hline 608 & 752253 & 1 & 658 & 873508 & 1 & 708 & 984658 & 1 \\
\hline 609 & 752630 & 1 & 659 & 874167 & 1 & 709 & 988462 & 1 \\
\hline 610 & 752901 & 1 & 660 & 874555 & 1 & 710 & 996710 & 1 \\
\hline 611 & 755649 & 1 & 661 & 877359 & 1 & 711 & 997035 & 1 \\
\hline 612 & 762162 & 1 & 662 & 877447 & 1 & 712 & 998060 & 1 \\
\hline 613 & 762224 & 1 & 663 & 878753 & 1 & & & \\
\hline 614 & 763534 & 1 & 664 & 882646 & 1 & & & \\
\hline 615 & 765456 & 1 & 665 & 886566 & 1 & & & \\
\hline 616 & 767486 & 1 & 666 & 887826 & 1 & & & \\
\hline 617 & 770954 & 1 & 667 & 893050 & 1 & & & \\
\hline 618 & 771648 & 1 & 668 & 899139 & 1 & & & \\
\hline 619 & 775437 & 1 & 669 & 899567 & 1 & & & \\
\hline 620 & 775913 & 1 & 670 & 900013 & 1 & & & \\
\hline 621 & 777236 & 1 & 671 & 902912 & 1 & & & \\
\hline 622 & 778764 & 1 & 672 & 905684 & 1 & & & \\
\hline 623 & 785760 & 1 & 673 & 906431 & 1 & & & \\
\hline 624 & 785930 & 1 & 674 & 909273 & 1 & & & \\
\hline 625 & 786357 & 1 & 675 & 911642 & 1 & & & \\
\hline 626 & 786627 & 1 & 676 & 912030 & 1 & & & \\
\hline 627 & 786889 & 1 & 677 & 913678 & 1 & & & \\
\hline 628 & 789648 & 1 & 678 & 916939 & 1 & & & \\
\hline 629 & 798915 & 1 & 679 & 921245 & 1 & & & \\
\hline 630 & 799683 & 1 & 680 & 922413 & 1 & & & \\
\hline 631 & 801358 & 1 & 681 & 924722 & 1 & & & \\
\hline 632 & 801827 & 1 & 682 & 924861 & 1 & & & \\
\hline 633 & 802041 & 1 & 683 & 925456 & 1 & & & \\
\hline 634 & 803176 & 1 & 684 & 925842 & 1 & & & \\
\hline 635 & 808378 & 1 & 685 & 933129 & 1 & & & \\
\hline 636 & 808777 & 1 & 686 & 934801 & 1 & & & \\
\hline 637 & 810662 & 1 & 687 & 935492 & 1 & & & \\
\hline 638 & 810820 & 1 & 688 & 936511 & 1 & & & \\
\hline 639 & 812266 & 1 & 689 & 937469 & 1 & & & \\
\hline 640 & 813190 & 1 & 690 & 938968 & 1 & & & \\
\hline 641 & 824168 & 1 & 691 & 939916 & 1 & & & \\
\hline 642 & 828395 & 1 & 692 & 945485 & 1 & & & \\
\hline 643 & 830752 & 1 & 693 & 948609 & 1 & & & \\
\hline 644 & 832450 & 1 & 694 & 952177 & 1 & & & \\
\hline 645 & 841624 & 1 & 695 & 952872 & 1 & & & \\
\hline 646 & 845830 & 1 & 696 & 953299 & 1 & & & \\
\hline 647 & 848795 & 1 & 697 & 953576 & 1 & & & \\
\hline 648 & 849022 & 1 & 698 & 954914 & 1 & & & \\
\hline 649 & 850960 & 1 & 699 & 958123 & 1 & & & \\
\hline 650 & 852055 & 1 & 700 & 962942 & 1 & & & \\
\hline
\end{tabular}

Nota: Tabela elaborada pela autora. 
O grau de intermediação, como visto, refere-se à questão de controle que os atores intermediários possuem sobre aqueles que dependem deles, tendo em vista que atores com alto grau de intermediação são pesquisadores mais bem posicionados na rede. $\mathrm{O}$ Gráfico 35 apresenta os indivíduos com maior grau de intermediação na Rede Ipea de 1995 a 2010.

\section{Gráfico 35 - Centralidade de Intermediação dos Atores no Período de 1995 a 2010}

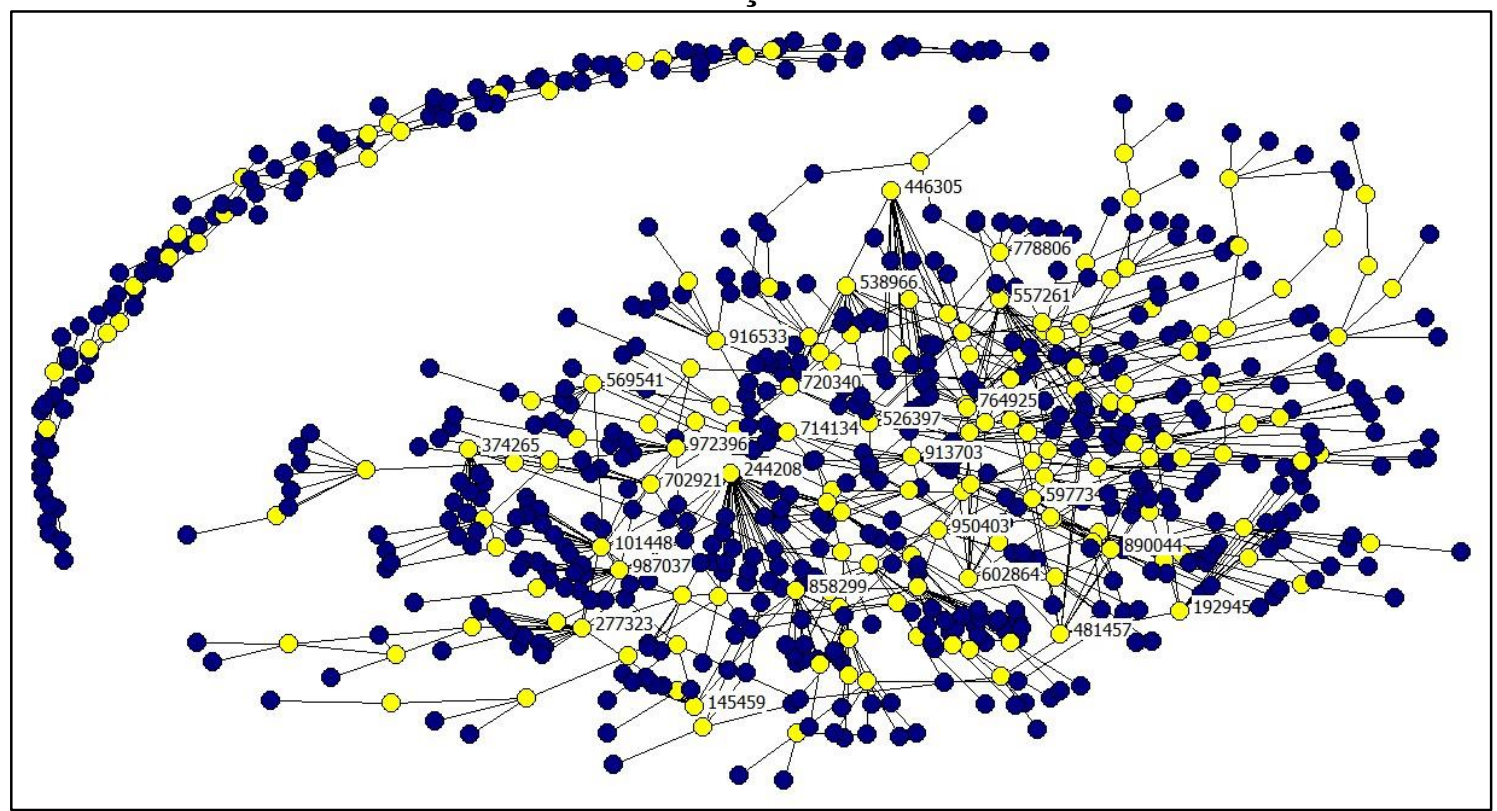

Nota: Elaboração da autora.

De um total de 712 atores na rede no terceiro período, 175 atores possuem grau de intermediação. Como podemos verificar, muitos atores que possuem alto grau nodal são também atores com alto grau de intermediação ou cutpoints. Neste terceiro período $24,57 \%$ dos atores fizeram a intermediação de relações de coautoria. Podemos considerar que os 175 atores com grau de intermediação igual a 1, listados na tabela 22 abaixo, contribuem para que a rede seja menos fragmentada neste período. No período anterior, 37 atores, de um total de 166, desempenharam o papel de intermediação, o que correspondia a $22,29 \%$ dos atores da rede no segundo período.

Como pode-se perceber, houve um aumento no percentual de atores que unem blocos na rede do segundo para o terceiro período. 
Tabela 22 - Centralidade de Intermediação dos Atores no Período de 1995 a 2010

\begin{tabular}{|c|c|c|c|c|c|}
\hline & Ator & Grau de intermediação & & Ator & Grau de intermediação \\
\hline 1 & 101448 & 1 & 51 & 394119 & 1 \\
\hline 2 & 105210 & 1 & 52 & 398798 & 1 \\
\hline 3 & 106525 & 1 & 53 & 403559 & 1 \\
\hline 4 & 113726 & 1 & 54 & 403577 & 1 \\
\hline 5 & 113844 & 1 & 55 & 405878 & 1 \\
\hline 6 & 115908 & 1 & 56 & 415043 & 1 \\
\hline 7 & 119871 & 1 & 57 & 424027 & 1 \\
\hline 8 & 136286 & 1 & 58 & 425435 & 1 \\
\hline 9 & 145459 & 1 & 59 & 426824 & 1 \\
\hline 10 & 154677 & 1 & 60 & 427755 & 1 \\
\hline 11 & 157074 & 1 & 61 & 437260 & 1 \\
\hline 12 & 174769 & 1 & 62 & 438227 & 1 \\
\hline 13 & 192945 & 1 & 63 & 443261 & 1 \\
\hline 14 & 194293 & 1 & 64 & 446305 & 1 \\
\hline 15 & 206032 & 1 & 65 & 449152 & 1 \\
\hline 16 & 220220 & 1 & 66 & 451276 & 1 \\
\hline 17 & 226329 & 1 & 67 & 467337 & 1 \\
\hline 18 & 226570 & 1 & 68 & 481457 & 1 \\
\hline 19 & 228253 & 1 & 69 & 482414 & 1 \\
\hline 20 & 228317 & 1 & 70 & 490550 & 1 \\
\hline 21 & 234372 & 1 & 71 & 498214 & 1 \\
\hline 22 & 235857 & 1 & 72 & 502447 & 1 \\
\hline 23 & 239355 & 1 & 73 & 510229 & 1 \\
\hline 24 & 240637 & 1 & 74 & 515289 & 1 \\
\hline 25 & 244208 & 1 & 75 & 515857 & 1 \\
\hline 26 & 244282 & 1 & 76 & 524828 & 1 \\
\hline 27 & 245783 & 1 & 77 & 526397 & 1 \\
\hline 28 & 255976 & 1 & 78 & 538966 & 1 \\
\hline 29 & 258152 & 1 & 79 & 549265 & 1 \\
\hline 30 & 261976 & 1 & 80 & 551725 & 1 \\
\hline 31 & 270937 & 1 & 81 & 555519 & 1 \\
\hline 32 & 277323 & 1 & 82 & 557261 & 1 \\
\hline 33 & 281259 & 1 & 83 & 565373 & 1 \\
\hline 34 & 282172 & 1 & 84 & 565446 & 1 \\
\hline 35 & 288536 & 1 & 85 & 569541 & 1 \\
\hline 36 & 294073 & 1 & 86 & 570846 & 1 \\
\hline 37 & 301347 & 1 & 87 & 572717 & 1 \\
\hline 38 & 303934 & 1 & 88 & 579356 & 1 \\
\hline 39 & 315243 & 1 & 89 & 590710 & 1 \\
\hline 40 & 317682 & 1 & 90 & 591547 & 1 \\
\hline 41 & 320941 & 1 & 91 & 597311 & 1 \\
\hline 42 & 327991 & 1 & 92 & 597734 & 1 \\
\hline 43 & 342088 & 1 & 93 & 601830 & 1 \\
\hline 44 & 345724 & 1 & 94 & 602864 & 1 \\
\hline 45 & 347180 & 1 & 95 & 605962 & 1 \\
\hline 46 & 365708 & 1 & 96 & 606897 & 1 \\
\hline 47 & 368412 & 1 & 97 & 607687 & 1 \\
\hline 48 & 372709 & 1 & 98 & 615690 & 1 \\
\hline 49 & 373711 & 1 & 99 & 623856 & 1 \\
\hline 50 & 374265 & 1 & 100 & 636334 & 1 \\
\hline
\end{tabular}




\begin{tabular}{|c|c|c|c|c|c|}
\hline & Ator & Grau de inter & & Ator & Grau de intermediação \\
\hline 101 & 640265 & 1 & 151 & 886230 & 1 \\
\hline 102 & 644032 & 1 & 152 & 890044 & 1 \\
\hline 103 & 644623 & 1 & 153 & 909456 & 1 \\
\hline 104 & 645079 & 1 & 154 & 913703 & 1 \\
\hline 105 & 665704 & 1 & 155 & 916533 & 1 \\
\hline 106 & 667182 & 1 & 156 & 919857 & 1 \\
\hline 107 & 667688 & 1 & 157 & 922121 & 1 \\
\hline 108 & 670853 & 1 & 158 & 927278 & 1 \\
\hline 109 & 672205 & 1 & 159 & 934480 & 1 \\
\hline 110 & 681599 & 1 & 160 & 936101 & 1 \\
\hline 111 & 687825 & 1 & 161 & 939878 & 1 \\
\hline 112 & 690817 & 1 & 162 & 941310 & 1 \\
\hline 113 & 695409 & 1 & 163 & 943547 & 1 \\
\hline 114 & 695567 & 1 & 164 & 945083 & 1 \\
\hline 115 & 702921 & 1 & 165 & 946030 & 1 \\
\hline 116 & 703903 & 1 & 166 & 946122 & 1 \\
\hline 117 & 703946 & 1 & 167 & 947367 & 1 \\
\hline 118 & 709498 & 1 & 168 & 950403 & 1 \\
\hline 119 & 714134 & 1 & 169 & 967301 & 1 \\
\hline 120 & 720340 & 1 & 170 & 972396 & 1 \\
\hline 121 & 730987 & 1 & 171 & 976649 & 1 \\
\hline 122 & 742671 & 1 & 172 & 986022 & 1 \\
\hline 123 & 750281 & 1 & 173 & 986373 & 1 \\
\hline 124 & 757305 & 1 & 174 & 987037 & 1 \\
\hline 125 & 758766 & 1 & 175 & 991698 & 1 \\
\hline 126 & 760607 & 1 & & & \\
\hline 127 & 764925 & 1 & & & \\
\hline 128 & 766189 & 1 & & & \\
\hline 129 & 770131 & 1 & & & \\
\hline 130 & 778806 & 1 & & & \\
\hline 131 & 780249 & 1 & & & \\
\hline 132 & 781167 & 1 & & & \\
\hline 133 & 788948 & 1 & & & \\
\hline 134 & 790379 & 1 & & & \\
\hline 135 & 793748 & 1 & & & \\
\hline 136 & 796925 & 1 & & & \\
\hline 137 & 800570 & 1 & & & \\
\hline 138 & 808647 & 1 & & & \\
\hline 139 & 815929 & 1 & & & \\
\hline 140 & 830622 & 1 & & & \\
\hline 141 & 834593 & 1 & & & \\
\hline 142 & 841404 & 1 & & & \\
\hline 143 & 841791 & 1 & & & \\
\hline 144 & 843320 & 1 & & & \\
\hline 145 & 854889 & 1 & & & \\
\hline 146 & 855367 & 1 & & & \\
\hline 147 & 858299 & 1 & & & \\
\hline 148 & 860164 & 1 & & & \\
\hline 149 & 875506 & 1 & & & \\
\hline 150 & 881065 & 1 & & & \\
\hline
\end{tabular}

Nota: Tabela elaborada pela autora. 
O Gráfico 36 destaca os atores de acordo com a medida de centralidade de grau e de intermediação. Interessante ver que os componentes menores da rede, que são os subgrafos dispersos na nuvem superior, também possuem atores com posição central e com grau de intermediação. Foi possível identificar ao menos 22 atores com grau de intermediação nos subgrafos menores.

\section{Gráfico 36 - Rede Ipea - 1995 a 2010 - Centralidade de Grau e Intermediação}

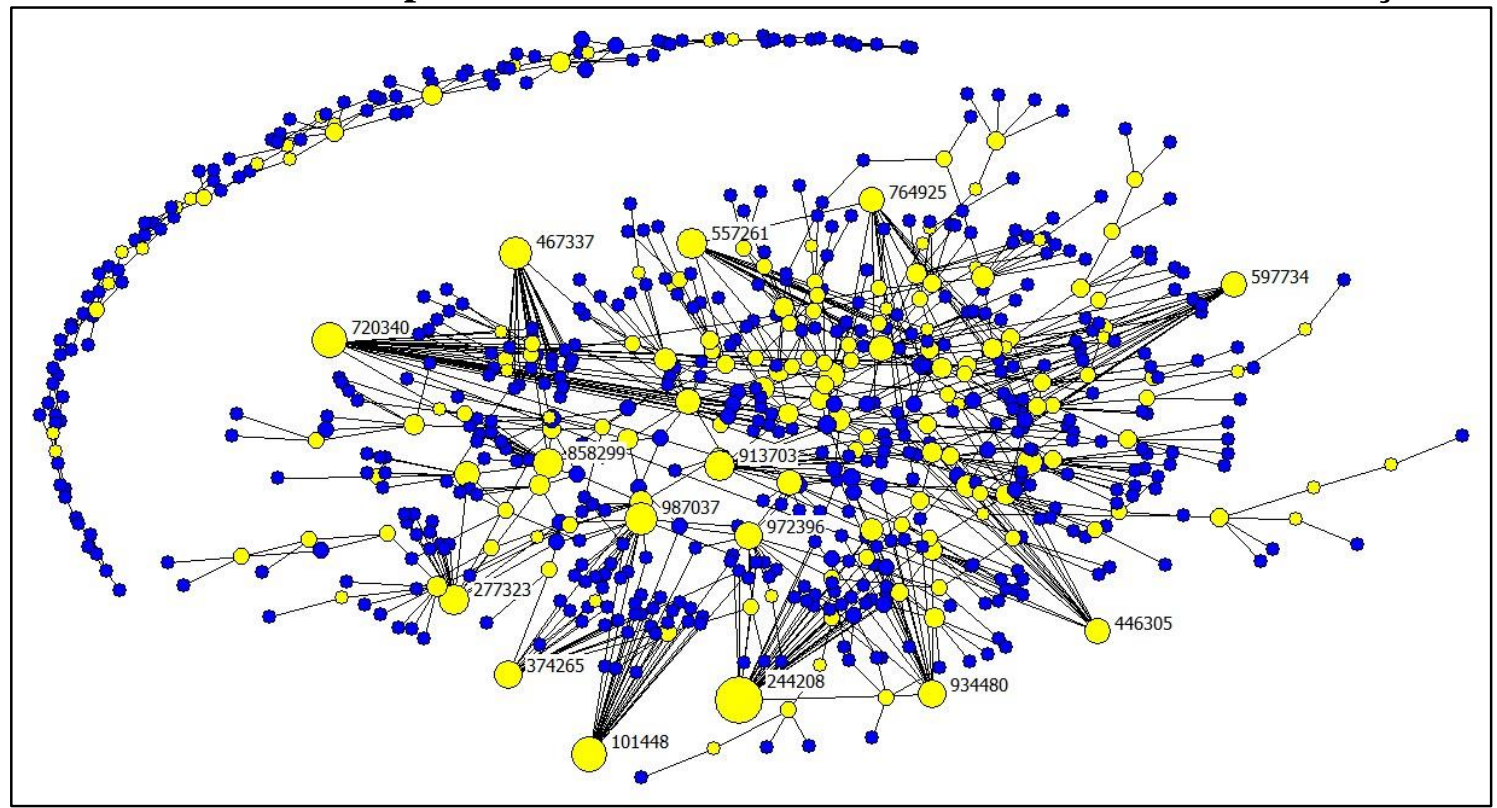

Nota: Elaboração da autora. 


\subsection{Análise da Rede Ipea: 1995 a 2010}

A rede neste terceiro período possui 712 atores. No segundo período tinha 166 atores e no primeiro a rede tinha 26 atores. Como visto, houve um aumento muito expressivo da rede do primeiro para o segundo e do segundo para o terceiro período.

Considerando as medidas de centralidade de todos os atores, podemos inferir algumas propriedades da rede como um todo. Ao somarmos os graus de todos os atores e dividirmos pelo número de atores, teremos o grau médio da rede. A soma dos graus de todos os atores, tabela 4, é $=1.648$. 1.648dividido por $712=2,3$, que é o grau da rede no terceiro período. O grau médio da rede no segundo período é = 1,90 e no grau médio da rede, que era 1,61 no primeiro período.

Na rede do terceiro período, que possui 712 atores, podemos dizer que cada ator pode ter, no máximo, grau absoluto $=711$ que é o número de laços possíveis para qualquer ator na rede. Interessante será verificar no contexto institucional desta rede, que é marcada pela especialização das diretorias de pesquisa do Ipea, quais são os laços potenciais para cada conjunto de atores, conforme os clans e clusters que se formaram em torno dos principais atores e cutpoints. A ênfase deve ser na rede e não nos grupos, nas relações e não nos atributos dos indivíduos. Neste sentido podemos verificar a dinâmica da rede enquanto circuito. Ainda sobre a formação de clans e clusters, a partir das relações de coautoria estabelecidas, interessante verificar a relação entre a vinculação do ator a determinada diretoria e a formação de clusters e cliques. 


\subsection{Comparação entre a rede de 1979 a 1984, 1985 a 1994 e 1995 e 2010}

Dos 11 atores que acompanhamos desde o primeiro período, constatamos que 5 atores "desapareceram" da rede neste terceiro período. Isso não quer dizer que eles não fazem parte da rede total, mas é como se tivessem apagado as suas "luzes" enquanto nós da rede, como se suas atividades tivessem ficado no "passado" da rede. Será que esses atores se aposentaram? Ou será que são os atores não têm vínculo permanente com o Ipea? São estes os atores que acompanhamos desde o primeiro período e que não estabeleceram relação de coautoria no terceiro período; 469115; 231748; 757056; 379457 e o 873256.

Dos 6 atores que permanecem em atividade na rede neste terceiro período, chamou a atenção dois atores, o 277323 e o 858299, que aumentaram seus graus nodais de 4 e 7 , para 17 e 16, respectivamente. Estes atores contribuíram para que o grau nodal total dos atores que permaneceram aumentasse de 35 para 47 , mesmo tendo 5 atores a menos. $\mathrm{O}$ ator 572717 teve um comportamento crescente no valor do seu grau nodal, e permanece na rede no terceiro período com grau nodal $=8$. O ator 365708 permanece na rede no terceiro período com grau nodal $=3$ e o ator 119871 permanece na rede no terceiro período com grau nodal $=2$, ambos obtiveram um pequeno aumento no grau nodal ao longo dos períodos analisados. O 520744 se mantém na rede, mas teve uma redução no seu grau nodal do segundo para o terceiro período.

Tabela 23 - Atores que Permaneceram na Rede do $1^{\circ}$ para o $2^{\circ}$ e do $2^{\circ}$ para o $3^{\circ}$ Período

\begin{tabular}{|c|c|c|c|c|}
\hline & Atores & Grau_10_período & Grau_2o_período & Grau_30_período \\
\hline 1 & 469115 & 4 & $\mathbf{1}$ & $\mathbf{0}$ \\
\hline 2 & 572717 & 4 & 5 & $\mathbf{8}$ \\
\hline 3 & 858299 & 3 & 7 & $\mathbf{1 6}$ \\
\hline 4 & 119871 & 2 & 1 & $\mathbf{2}$ \\
\hline 6 & 231748 & 2 & 2 & $\mathbf{0}$ \\
\hline 9 & 757056 & 2 & 5 & $\mathbf{0}$ \\
\hline 14 & 277323 & 1 & 4 & $\mathbf{1 7}$ \\
\hline 15 & 365708 & 1 & 1 & $\mathbf{3}$ \\
\hline 16 & 379457 & 1 & 2 & $\mathbf{0}$ \\
\hline 20 & 520744 & 1 & 3 & $\mathbf{1}$ \\
\hline 23 & 873256 & 1 & 4 & $\mathbf{0}$ \\
\hline $\mathbf{1 1}$ & total & 22 & $\mathbf{3 5}$ & 47 \\
\hline
\end{tabular}

Nota: Tabela elaborada pela autora.

Se somarmos o grau nodal cumulativo dos seis atores que permanecem nos 3 períodos analisados, teremos:

Tabela 24 - Soma do grau Nodal Cumulativo

\begin{tabular}{|c|c|c|}
\hline & Ator & Soma nos 3 periodos \\
\hline 1 & 858299 & 26 \\
\hline 2 & 277323 & 22 \\
\hline 3 & 572717 & 17 \\
\hline 4 & 365708 & 5 \\
\hline 5 & 520744 & 5 \\
\hline 6 & 119871 & 5 \\
\hline
\end{tabular}

Nota: Tabela elaborada pela autora. 
5.16 Comparação entre a rede de 1985 a 1994 e 1995 e 2010 ( $2^{\circ}$ período x $3^{\circ}$ período)

Tabela 25 - Atores que Permaneceram na Rede Ipea do $2^{\circ}$ Período para $3^{\circ}$ Período e Tiveram um Aumento do Grau Nodal

\begin{tabular}{|c|c|c|c|}
\hline & Atores & Grau_2o_período & Grau_3o_período \\
\hline 1 & 244208 & 18 & 32 \\
\hline 2 & 467337 & 7 & 19 \\
\hline 3 & 858299 & 7 & 16 \\
\hline 4 & 987037 & 6 & 18 \\
\hline 5 & 572717 & 5 & 8 \\
\hline 6 & 605962 & 5 & 8 \\
\hline 7 & 277323 & 4 & 17 \\
\hline 8 & 524828 & 4 & 8 \\
\hline 9 & 101448 & 3 & 20 \\
\hline 10 & 173034 & 2 & 3 \\
\hline 11 & 278902 & 2 & 3 \\
\hline 12 & 936101 & 2 & 5 \\
\hline 13 & 119871 & 1 & 2 \\
\hline 14 & 192416 & 1 & 2 \\
\hline 15 & 193060 & 1 & 2 \\
\hline 16 & 201056 & 1 & 3 \\
\hline 17 & 303934 & 1 & 6 \\
\hline 18 & 365708 & 1 & 3 \\
\hline 19 & 374265 & 1 & 14 \\
\hline 20 & 379562 & 1 & 2 \\
\hline 21 & 481457 & 1 & 9 \\
\hline 22 & 502447 & 1 & 3 \\
\hline 23 & 557261 & 1 & 16 \\
\hline 24 & 565373 & 1 & 4 \\
\hline 25 & 606897 & 1 & 3 \\
\hline 26 & 615690 & 1 & 2 \\
\hline 27 & 702921 & 1 & 9 \\
\hline 28 & 709498 & 1 & 2 \\
\hline 29 & 758766 & 1 & 4 \\
\hline 30 & 972647 & 1 & 3 \\
\hline \multirow[t]{2}{*}{31} & 976649 & 1 & 8 \\
\hline & & 84 & 254 \\
\hline
\end{tabular}

Nota: Tabela elaborada pela autora.

Gráfico 37 - Atores que Permaneceram na Rede Ipea do $2^{\circ}$ para o $3^{\circ}$ Período e Tiveram um Aumento no Grau Nodal

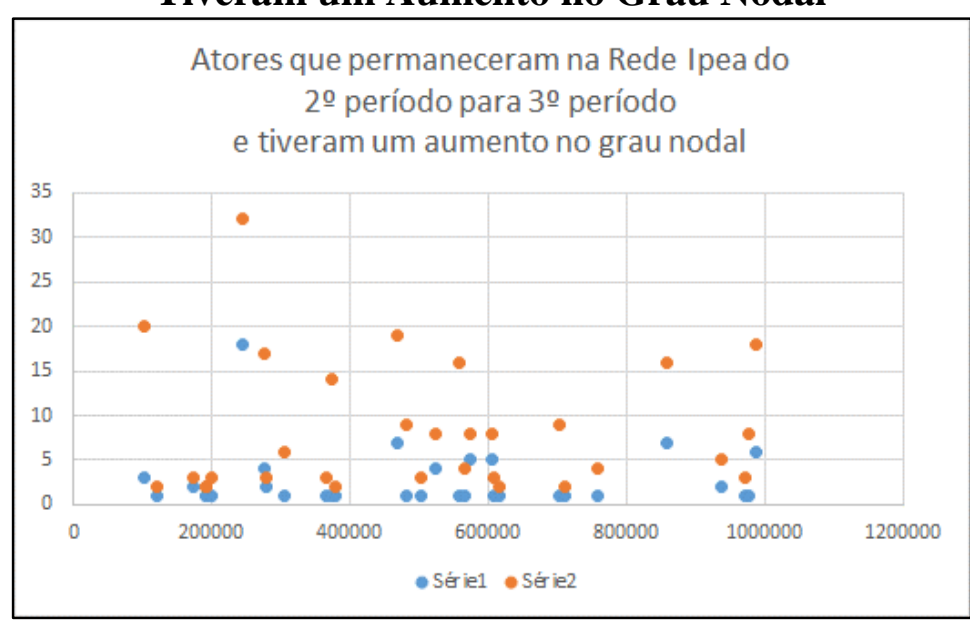

Nota: Elaboração da autora. 
Tabela 26 - Atores que Permaneceram na Rede Ipea do $2^{\circ}$ Período para $3^{\circ}$ Período e Mantiveram o Grau Nodal

\begin{tabular}{|c|c|c|c|}
\hline & Atores & Grau_2o_período & Grau_3o_período \\
\hline 1 & 368412 & 3 & $\mathbf{3}$ \\
\hline 2 & 962477 & 2 & $\mathbf{2}$ \\
\hline 3 & 116298 & 1 & $\mathbf{1}$ \\
\hline 4 & 265761 & 1 & $\mathbf{1}$ \\
\hline 5 & 411859 & 1 & $\mathbf{1}$ \\
\hline 6 & 415392 & 1 & $\mathbf{1}$ \\
\hline 7 & 419447 & 1 & $\mathbf{1}$ \\
\hline 8 & 475755 & 1 & $\mathbf{1}$ \\
\hline 9 & 650015 & 1 & $\mathbf{1}$ \\
\hline 10 & 713283 & 1 & $\mathbf{1}$ \\
\hline 11 & 882646 & 1 & $\mathbf{1}$ \\
\hline 12 & 909273 & 1 & $\mathbf{1}$ \\
\hline
\end{tabular}

Nota: Tabela elaborada pela autora.

Gráfico 38 - Atores que Permaneceram na Rede Ipea do $2^{\circ}$ para o $3^{\circ}$ Período e Mantiveram o Grau Nodal

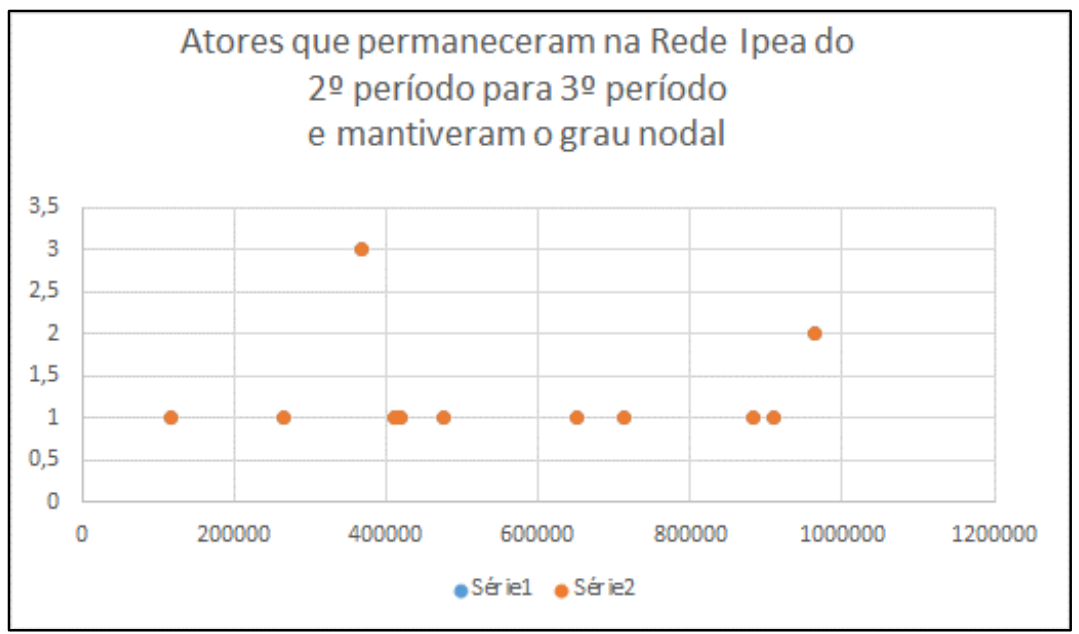

Nota: Elaboração da autora. 
Tabela 27 - Atores que Permaneceram na Rede Ipea do $2^{\circ}$ Período para $3^{\circ}$ Período

e Tiveram uma Redução do Grau Nodal
\begin{tabular}{|c|c|c|c|}
\hline & Atores & Grau_2o_período & Grau_3o_período \\
\hline 1 & 695409 & 9 & $\mathbf{3}$ \\
\hline 2 & 228253 & 8 & $\mathbf{6}$ \\
\hline 3 & 288536 & 8 & $\mathbf{6}$ \\
\hline 4 & 559786 & 4 & $\mathbf{1}$ \\
\hline 5 & 520744 & 3 & $\mathbf{1}$ \\
\hline 6 & 577095 & 3 & $\mathbf{1}$ \\
\hline 7 & 752901 & 2 & $\mathbf{1}$ \\
\hline & & 37 & 19 \\
\hline
\end{tabular}

Nota: Tabela elaborada pela autora.

Gráfico 39 - Atores que Permaneceram na Rede Ipea do $2^{\circ}$ para o $3^{\circ}$ Período e Tiveram uma Redução no Grau Nodal

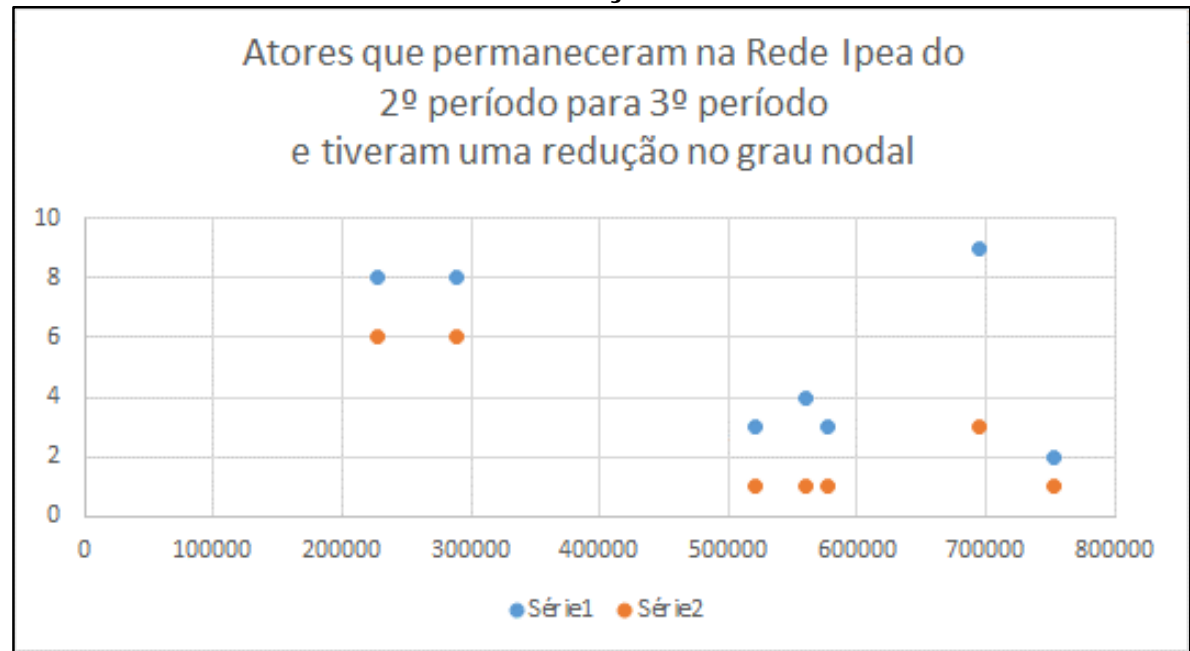

Nota: Elaboração da autora. 
Tabela 28 - Atores que Não Permaneceram na Rede Ipea do $2^{\circ}$ Período para $3^{\circ}$

\section{Período}

\begin{tabular}{|c|c|c|c|c|c|c|c|}
\hline & Atores & Grau_2o_período & Grau_3﹎período & & Atores & Grau_2o_período & Grau_3o_período \\
\hline 1 & 247255 & 7 & 0 & 59 & 404800 & 1 & 0 \\
\hline 2 & 804408 & 7 & 0 & 60 & 405531 & 1 & 0 \\
\hline 3 & 113229 & 6 & 0 & 61 & 410898 & 1 & 0 \\
\hline 4 & 793415 & 6 & 0 & 62 & 416680 & 1 & 0 \\
\hline 5 & 569790 & 5 & 0 & 63 & 431669 & 1 & 0 \\
\hline 6 & 757056 & 5 & 0 & 64 & 459631 & 1 & 0 \\
\hline 7 & 827203 & 5 & 0 & 65 & 459972 & 1 & $\mathbf{0}$ \\
\hline 8 & 365844 & 4 & 0 & 66 & 460847 & 1 & 0 \\
\hline 9 & 873256 & 4 & 0 & 67 & 469115 & 1 & 0 \\
\hline 10 & 172339 & 3 & 0 & 68 & 478780 & 1 & 0 \\
\hline 11 & 116937 & 2 & 0 & 69 & 478824 & 1 & 0 \\
\hline 12 & 230122 & 2 & 0 & 70 & 478956 & 1 & 0 \\
\hline 13 & 231748 & 2 & 0 & 71 & 484872 & 1 & 0 \\
\hline 14 & 249523 & 2 & 0 & 72 & 488071 & 1 & 0 \\
\hline 15 & 273319 & 2 & 0 & 73 & 497562 & 1 & 0 \\
\hline 16 & 278997 & 2 & 0 & 74 & 507257 & 1 & 0 \\
\hline 17 & 287533 & 2 & 0 & 75 & 519233 & 1 & 0 \\
\hline 18 & 379457 & 2 & 0 & 76 & 547176 & 1 & 0 \\
\hline 19 & 411245 & 2 & 0 & 77 & 553089 & 1 & 0 \\
\hline 20 & 430909 & 2 & 0 & 78 & 558104 & 1 & 0 \\
\hline 21 & 476379 & 2 & 0 & 79 & 562669 & 1 & 0 \\
\hline 22 & 589197 & 2 & 0 & 80 & 569931 & 1 & 0 \\
\hline 23 & 599193 & 2 & 0 & 81 & 584283 & 1 & 0 \\
\hline 24 & 600058 & 2 & 0 & 82 & 587221 & 1 & 0 \\
\hline 25 & 648083 & 2 & 0 & 83 & 610369 & 1 & 0 \\
\hline 26 & 726588 & 2 & 0 & 84 & 612161 & 1 & 0 \\
\hline 27 & 863346 & 2 & 0 & 85 & 647430 & 1 & 0 \\
\hline 28 & 908813 & 2 & 0 & 86 & 655768 & 1 & 0 \\
\hline 29 & 923507 & 2 & 0 & 87 & 656920 & 1 & 0 \\
\hline 30 & 948248 & 2 & 0 & 88 & 695729 & 1 & 0 \\
\hline 31 & 976110 & 2 & 0 & 89 & 704026 & 1 & 0 \\
\hline 32 & 981814 & 2 & 0 & 90 & 704200 & 1 & 0 \\
\hline 33 & 100930 & 1 & 0 & 91 & 723859 & 1 & 0 \\
\hline 34 & 103781 & 1 & 0 & 92 & 732623 & 1 & 0 \\
\hline 35 & 110830 & 1 & 0 & 93 & 741482 & 1 & 0 \\
\hline 36 & 116674 & 1 & 0 & 94 & 748836 & 1 & 0 \\
\hline 37 & 117719 & 1 & 0 & 95 & 757745 & 1 & 0 \\
\hline 38 & 125561 & 1 & 0 & 96 & 786256 & 1 & 0 \\
\hline 39 & 127181 & 1 & 0 & 97 & 813373 & 1 & 0 \\
\hline 40 & 135051 & 1 & 0 & 98 & 839887 & 1 & 0 \\
\hline 41 & 137526 & 1 & 0 & 99 & 845944 & 1 & 0 \\
\hline 42 & 141716 & 1 & 0 & 100 & 857339 & 1 & 0 \\
\hline 43 & 143598 & 1 & 0 & 101 & 870383 & 1 & 0 \\
\hline 44 & 155022 & 1 & 0 & 102 & 884139 & 1 & 0 \\
\hline 45 & 187768 & 1 & 0 & 103 & 888415 & 1 & 0 \\
\hline 46 & 195078 & 1 & 0 & 104 & 893954 & 1 & 0 \\
\hline 47 & 214803 & 1 & 0 & 105 & 895768 & 1 & 0 \\
\hline 48 & 269148 & 1 & 0 & 106 & 906439 & 1 & 0 \\
\hline 49 & 282432 & 1 & 0 & 107 & 910279 & 1 & 0 \\
\hline 50 & 298090 & 1 & 0 & 108 & 916824 & 1 & 0 \\
\hline 51 & 312015 & 1 & 0 & 109 & 927273 & 1 & 0 \\
\hline 52 & 335764 & 1 & 0 & 110 & 929624 & 1 & 0 \\
\hline 53 & 364655 & 1 & 0 & 111 & 949753 & 1 & 0 \\
\hline 54 & 375681 & 1 & 0 & 112 & 961753 & 1 & 0 \\
\hline 55 & 377382 & 1 & 0 & 113 & 968635 & 1 & 0 \\
\hline 56 & 377900 & 1 & 0 & 114 & 987234 & 1 & 0 \\
\hline 57 & 391402 & 1 & 0 & 115 & 993597 & 1 & 0 \\
\hline 58 & 392761 & 1 & 0 & 116 & 993981 & 1 & 0 \\
\hline
\end{tabular}

Nota: Tabela elaborada pela autora. 


\subsection{O quarto período escolhido para a análise da Rede Ipea foi: 2011 a 2016}

O Gráfico 40 traz o primeiro desenho da rede para este quarto e último período analisado. $\mathrm{O}$ quarto período e o primeiro período são os menores períodos dentre os quatro escolhidos. Foi interessante ver como é o desenho da rede, com uma grande quantidade de dados grande. A experiência inicial dos 37 anos, Gráfico 18, e o terceiro período, Gráfico 33, não mostraram a rede com riqueza de detalhes. Fecha-se este estudo de ARS da Rede Ipea com o menor período, cerca de 5 anos e 5 meses. Nesse período, a rede apresentou um aumento na quantidade média de publicações da série. Em valores médios, 109,5 TDs foram publicados por ano de gestão para este período.

O Gráfico 40 mostra em detalhes o componente principal deste período, sendo possível verificar detalhes da rede a partir das colaborações de coautoria estabelecidas entre 481 atores. A nuvem de componentes menores também pode ser vista com maior riqueza de detalhes no grafo que listamos a seguir, como podemos ver não é possível estabelecer um caminho entre muitos nós e tantos outros da rede, estando ela neste período desconectada.

\section{Gráfico 40 - Rede Ipea - 2011 a 2016 - Centralidade de Intermediação}

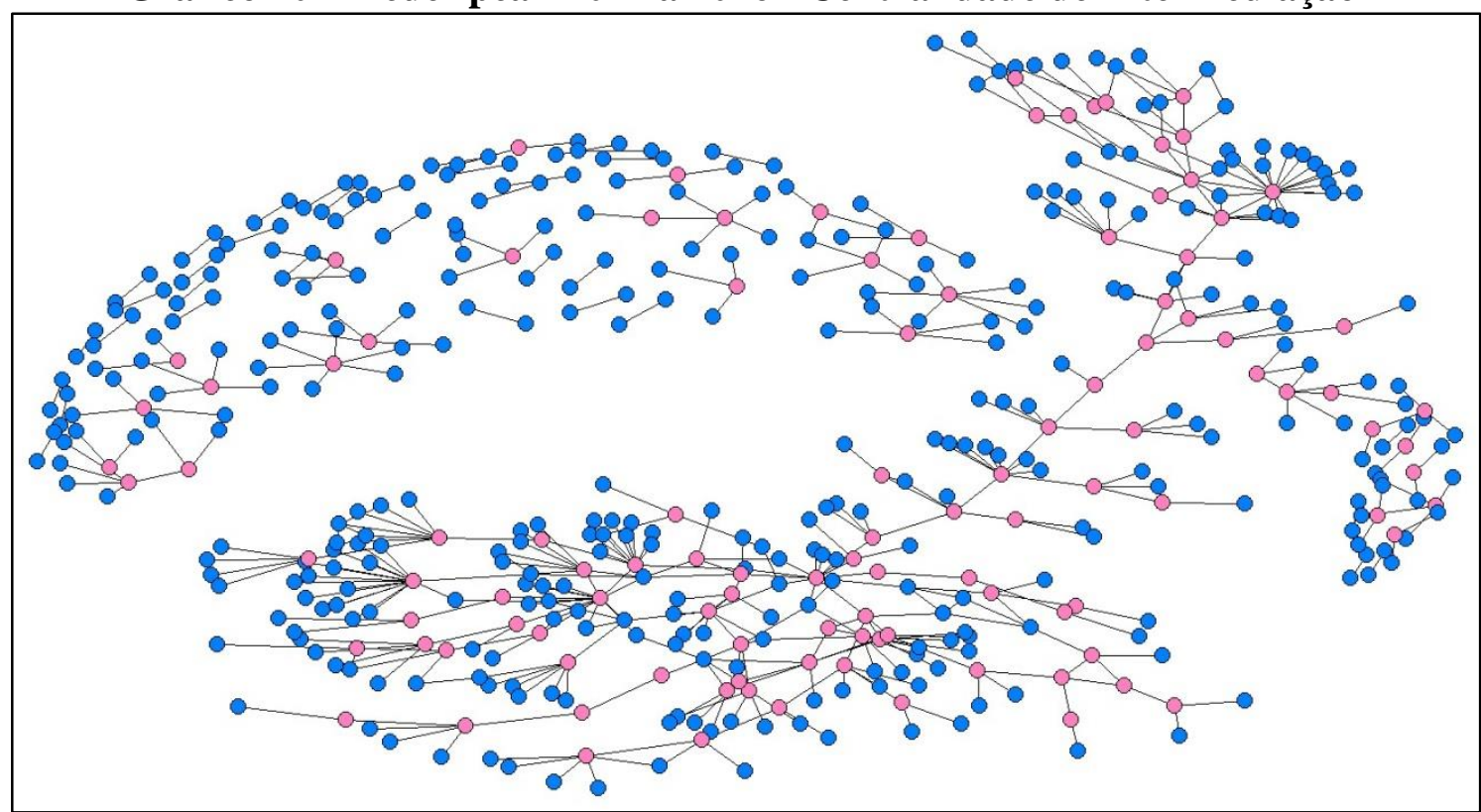

Nota: Elaboração da autora.

O grande componente pode ser visto no centro do grafo. À direita e abaixo pode-se ver um falso componente médio, que parece estar quase todo conectado e está bem próximo do componente principal. Esses componentes encontram-se bem próximos uns dos outros, mantendo uma distância maior dos outros pequenos componentes que estão acima, à esquerda, na nuvem de componentes menores. Como visto, os componentes menores que se formaram neste último período têm formas variadas, sendo possível ver que a maioria dos subgrafos com mais de quatro indivíduos formam redes do tipo estrela, mas não somente redes tipo estrela. Nota-se também um grande número de díades e tríades na nuvem de componentes menores. 
Os atores principais da rede neste último período, que têm o maior grau nodal da Rede Ipea, estão destacados em tamanhos variados de nós, no grafo 11, de acordo com o grau de centralidade de cada um. Ao todo 26 atores estão identificados com as etiquetas de códigos no grafo 11 abaixo e possuem grau nodal que varia de 19 a 6 .

\section{Gráfico 41 - Rede Ipea - 2011 a 2016 - Centralidade de Grau}

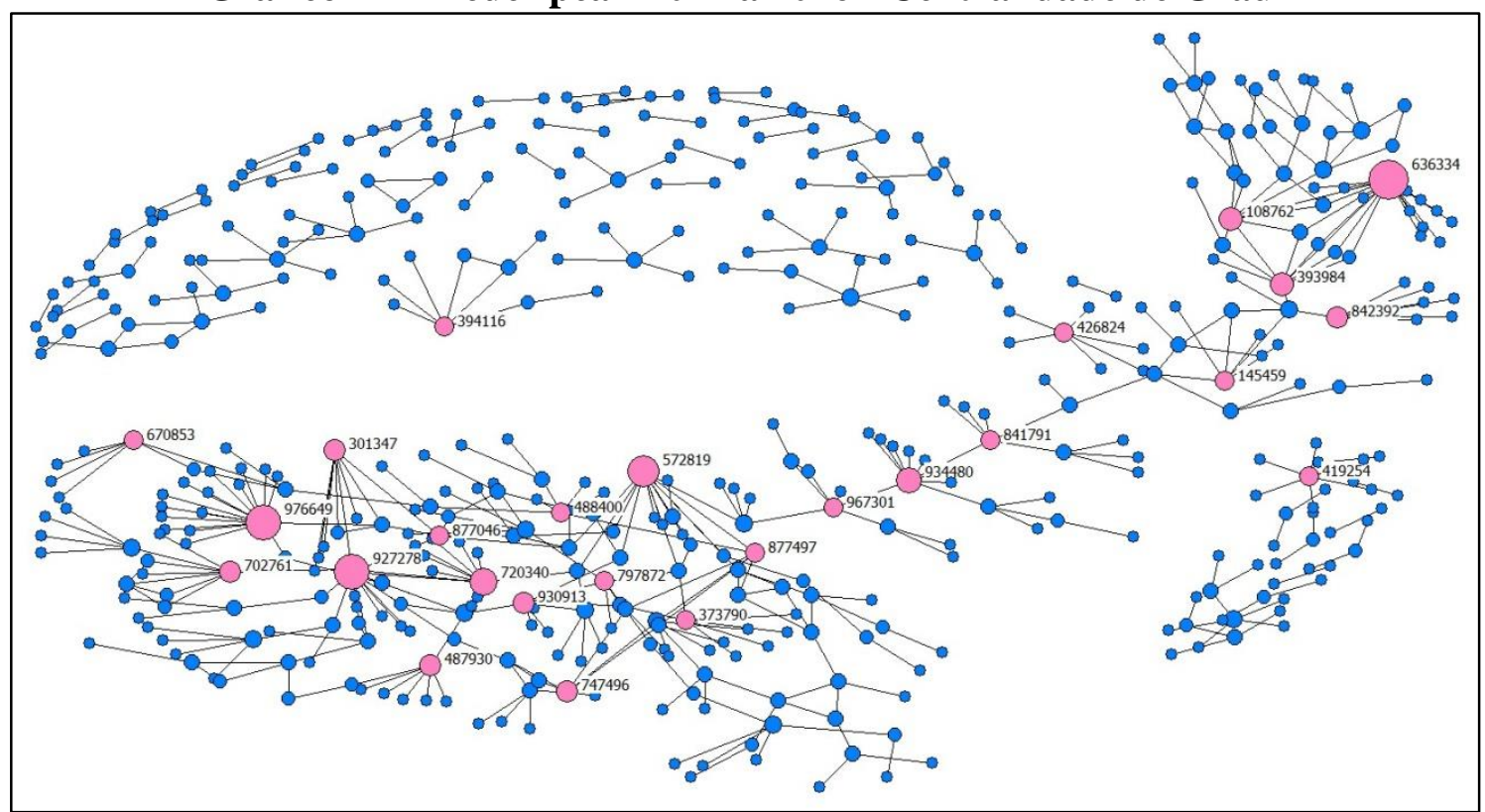

Nota: Elaboração da autora.

Os 10 atores que possuem o maior grau nodal da rede para este quarto período estão listados na Tabela 29. Esses dez atores estabeleceram o maior número de relações de coautoria neste período. Como vimos, o número de "conexões" ou laços nos fornece o grau de centralidade de um ator. Quanto mais centrais são os atores em uma rede, mais importantes são esses atores.

Tabela 29 - Dez Principais Atores no $4^{\circ}$ Período

\begin{tabular}{|c|c|c|}
\hline & ator & Grau \\
\hline 1 & 636334 & 19 \\
\hline 2 & 927278 & 16 \\
\hline 3 & 976649 & 16 \\
\hline 4 & 572819 & 14 \\
\hline 5 & 720340 & 11 \\
\hline 6 & 934480 & 10 \\
\hline 7 & 108762 & 9 \\
\hline 8 & 393984 & 9 \\
\hline 9 & 301347 & 8 \\
\hline 10 & 702761 & 8 \\
\hline
\end{tabular}

Nota: Tabela elaborada pela autora. 
O falso componente médio, Gráfico 42, é formado por subgrafos variados, tendo uma rede tipo estrela em destaque. O nó central, o 419254, está ligado diretamente aos atores da sua rede e podemos dizer que possui uma posição privilegiada em relação aos demais nós de da rede estrela. Como visto, não se trata de um componente apenas, mas de vários componentes menores agrupados longe da nuvem.

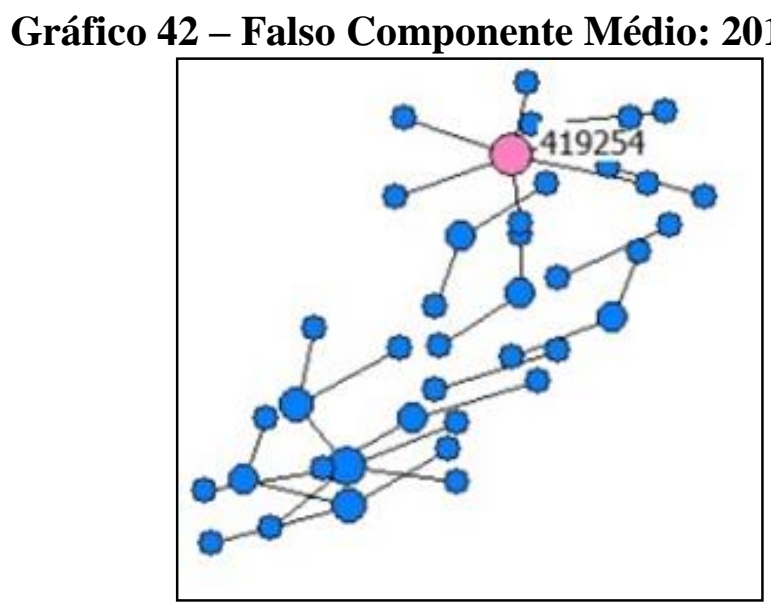

Nota: Elaboração da autora.

Um componente que está disperso na nuvem superior, tem o ator 394116 como nó central e é composto por nove atores ao todo.

Gráfico 43 - Componente Disperso na nuvem da Rede Ipea: 2011 a 2016

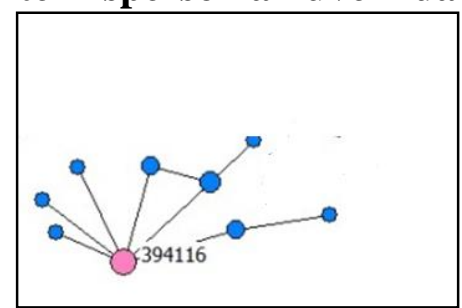

Nota: Elaboração da autora.

A Tabela 30 apresenta o grau de centralidade de todos os 481 atores da rede no quarto período. 
Tabela 30 - Centralidade de Grau dos Atores no Período de 2011 a 2016

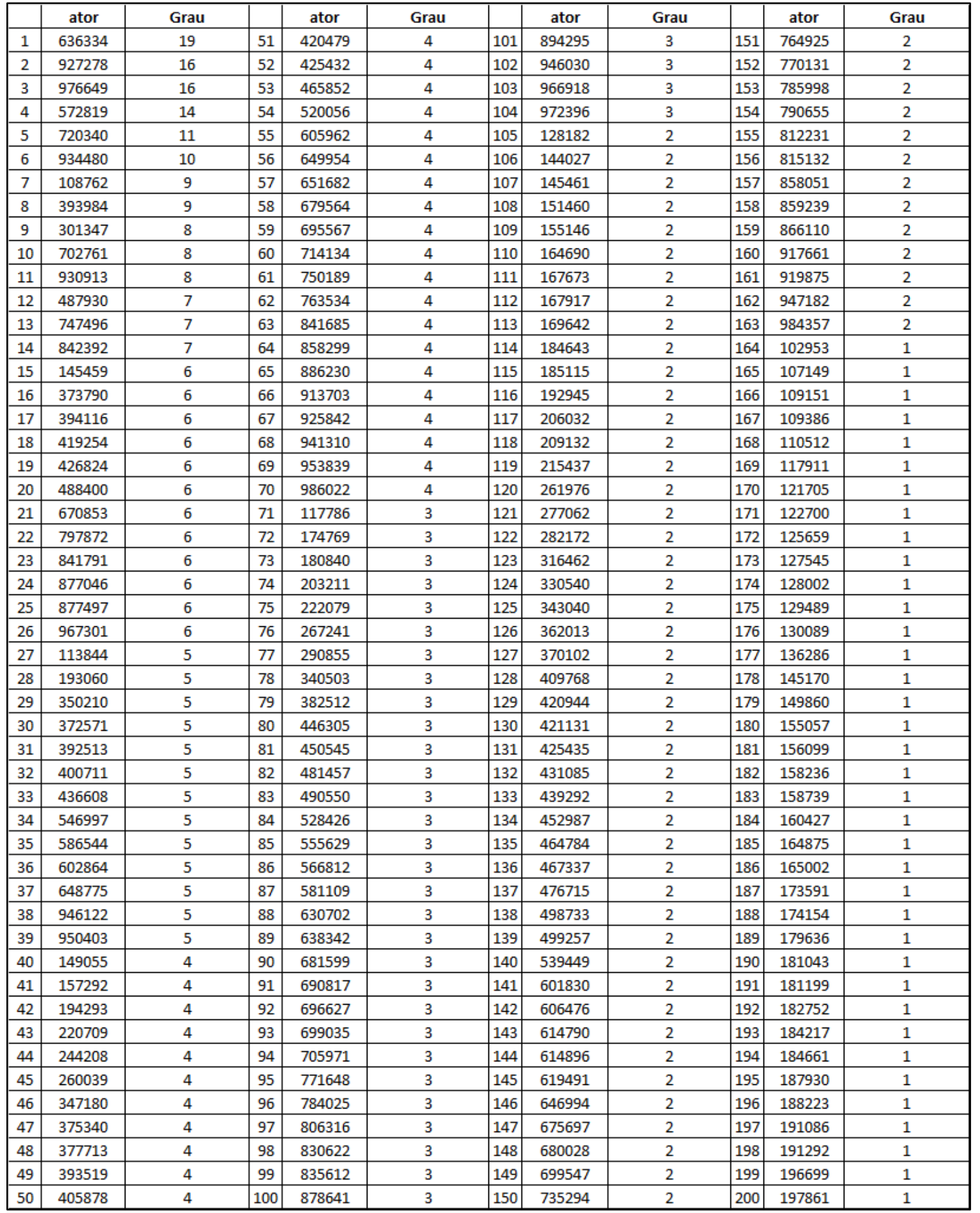




\begin{tabular}{|c|c|c|c|c|c|c|c|c|c|c|c|}
\hline & ator & Grau & & ator & Grau & & ator & Grau & & ator & Grau \\
\hline 201 & 202043 & 1 & 251 & 327811 & 1 & 301 & 460596 & 1 & 351 & 588242 & 1 \\
\hline 202 & 203401 & 1 & 252 & 327926 & 1 & 302 & 461860 & 1 & 352 & 591547 & 1 \\
\hline 203 & 208566 & 1 & 253 & 328710 & 1 & 303 & 467715 & 1 & 353 & 593586 & 1 \\
\hline 204 & 208642 & 1 & 254 & 336496 & 1 & 304 & 468108 & 1 & 354 & 597429 & 1 \\
\hline 205 & 209716 & 1 & 255 & 336731 & 1 & 305 & 468659 & 1 & 355 & 602237 & 1 \\
\hline 206 & 210212 & 1 & 256 & 337467 & 1 & 306 & 474005 & 1 & 356 & 604124 & 1 \\
\hline 207 & 220220 & 1 & 257 & 340400 & 1 & 307 & 474464 & 1 & 357 & 607687 & 1 \\
\hline 208 & 226617 & 1 & 258 & 341299 & 1 & 308 & 475422 & 1 & 358 & 612673 & 1 \\
\hline 209 & 227797 & 1 & 259 & 342088 & 1 & 309 & 477226 & 1 & 359 & 614875 & 1 \\
\hline 210 & 228738 & 1 & 260 & 344277 & 1 & 310 & 479241 & 1 & 360 & 619190 & 1 \\
\hline 211 & 232265 & 1 & 261 & 345773 & 1 & 311 & 480635 & 1 & 361 & 621615 & 1 \\
\hline 212 & 235857 & 1 & 262 & 349065 & 1 & 312 & 482219 & 1 & 362 & 623430 & 1 \\
\hline 213 & 235945 & 1 & 263 & 351254 & 1 & 313 & 484485 & 1 & 363 & 626042 & 1 \\
\hline 214 & 239355 & 1 & 264 & 357202 & 1 & 314 & 487982 & 1 & 364 & 630769 & 1 \\
\hline 215 & 240877 & 1 & 265 & 361322 & 1 & 315 & 491334 & 1 & 365 & 637288 & 1 \\
\hline 216 & 242135 & 1 & 266 & 362511 & 1 & 316 & 493954 & 1 & 366 & 637872 & 1 \\
\hline 217 & 243348 & 1 & 267 & 364911 & 1 & 317 & 495840 & 1 & 367 & 637923 & 1 \\
\hline 218 & 244493 & 1 & 268 & 365112 & 1 & 318 & 506907 & 1 & 368 & 641234 & 1 \\
\hline 219 & 247032 & 1 & 269 & 366183 & 1 & 319 & 507311 & 1 & 369 & 647616 & 1 \\
\hline 220 & 248890 & 1 & 270 & 368237 & 1 & 320 & 507554 & 1 & 370 & 653522 & 1 \\
\hline 221 & 252414 & 1 & 271 & 368579 & 1 & 321 & 507851 & 1 & 371 & 654527 & 1 \\
\hline 222 & 257297 & 1 & 272 & 370942 & 1 & 322 & 510736 & 1 & 372 & 658999 & 1 \\
\hline 223 & 260931 & 1 & 273 & 372709 & 1 & 323 & 513496 & 1 & 373 & 660577 & 1 \\
\hline 224 & 262846 & 1 & 274 & 377088 & 1 & 324 & 514576 & 1 & 374 & 660593 & 1 \\
\hline 225 & 263676 & 1 & 275 & 379059 & 1 & 325 & 515857 & 1 & 375 & 663290 & 1 \\
\hline 226 & 266442 & 1 & 276 & 382509 & 1 & 326 & 518112 & 1 & 376 & 667182 & 1 \\
\hline 227 & 267116 & 1 & 277 & 384560 & 1 & 327 & 526474 & 1 & 377 & 671261 & 1 \\
\hline 228 & 268051 & 1 & 278 & 391807 & 1 & 328 & 529103 & 1 & 378 & 674154 & 1 \\
\hline 229 & 269557 & 1 & 279 & 392026 & 1 & 329 & 532261 & 1 & 379 & 675027 & 1 \\
\hline 230 & 270937 & 1 & 280 & 393833 & 1 & 330 & 532418 & 1 & 380 & 675962 & 1 \\
\hline 231 & 271015 & 1 & 281 & 399624 & 1 & 331 & 540115 & 1 & 381 & 683483 & 1 \\
\hline 232 & 272790 & 1 & 282 & 403577 & 1 & 332 & 544615 & 1 & 382 & 685116 & 1 \\
\hline 233 & 274436 & 1 & 283 & 404403 & 1 & 333 & 551725 & 1 & 383 & 686544 & 1 \\
\hline 234 & 279615 & 1 & 284 & 409000 & 1 & 334 & 553074 & 1 & 384 & 686986 & 1 \\
\hline 235 & 279875 & 1 & 285 & 413888 & 1 & 335 & 553602 & 1 & 385 & 687183 & 1 \\
\hline 236 & 281011 & 1 & 286 & 419447 & 1 & 336 & 553613 & 1 & 386 & 689569 & 1 \\
\hline 237 & 281545 & 1 & 287 & 421555 & 1 & 337 & 554628 & 1 & 387 & 693405 & 1 \\
\hline 238 & 282124 & 1 & 288 & 422349 & 1 & 338 & 557261 & 1 & 388 & 694790 & 1 \\
\hline 239 & 282445 & 1 & 289 & 429494 & 1 & 339 & 557818 & 1 & 389 & 699453 & 1 \\
\hline 240 & 283730 & 1 & 290 & 430347 & 1 & 340 & 559786 & 1 & 390 & 708133 & 1 \\
\hline 241 & 284074 & 1 & 291 & 432436 & 1 & 341 & 562465 & 1 & 391 & 720142 & 1 \\
\hline 242 & 284599 & 1 & 292 & 436164 & 1 & 342 & 563102 & 1 & 392 & 725331 & 1 \\
\hline 243 & 291169 & 1 & 293 & 438216 & 1 & 343 & 564120 & 1 & 393 & 726373 & 1 \\
\hline 244 & 296103 & 1 & 294 & 441139 & 1 & 344 & 565981 & 1 & 394 & 732722 & 1 \\
\hline 245 & 300160 & 1 & 295 & 443261 & 1 & 345 & 571557 & 1 & 395 & 733113 & 1 \\
\hline 246 & 305775 & 1 & 296 & 448201 & 1 & 346 & 574283 & 1 & 396 & 738628 & 1 \\
\hline 247 & 314087 & 1 & 297 & 453705 & 1 & 347 & 575727 & 1 & 397 & 740107 & 1 \\
\hline 248 & 317790 & 1 & 298 & 454642 & 1 & 348 & 583029 & 1 & 398 & 742650 & 1 \\
\hline 249 & 319080 & 1 & 299 & 456499 & 1 & 349 & 585996 & 1 & 399 & 742671 & 1 \\
\hline 250 & 320941 & 1 & 300 & 459781 & 1 & 350 & 587143 & 1 & 400 & 743230 & 1 \\
\hline
\end{tabular}




\begin{tabular}{|l|c|c|c|c|c|}
\hline & ator & Grau & & ator & Grau \\
\hline 401 & 746822 & 1 & 442 & 878349 & 1 \\
\hline 402 & 748836 & 1 & 443 & 880316 & 1 \\
\hline 403 & 753728 & 1 & 444 & 880325 & 1 \\
\hline 404 & 754404 & 1 & 445 & 884625 & 1 \\
\hline 405 & 755747 & 1 & 446 & 888042 & 1 \\
\hline 406 & 756191 & 1 & 447 & 889721 & 1 \\
\hline 407 & 759682 & 1 & 448 & 891128 & 1 \\
\hline 408 & 762536 & 1 & 449 & 891680 & 1 \\
\hline 409 & 764068 & 1 & 450 & 899139 & 1 \\
\hline 410 & 765759 & 1 & 451 & 899574 & 1 \\
\hline 411 & 766189 & 1 & 452 & 900134 & 1 \\
\hline 412 & 766529 & 1 & 453 & 900202 & 1 \\
\hline 413 & 768269 & 1 & 454 & 903651 & 1 \\
\hline 414 & 781241 & 1 & 455 & 909459 & 1 \\
\hline 415 & 785667 & 1 & 456 & 913069 & 1 \\
\hline 416 & 791295 & 1 & 457 & 915467 & 1 \\
\hline 417 & 793410 & 1 & 458 & 919269 & 1 \\
\hline 418 & 796013 & 1 & 459 & 919857 & 1 \\
\hline 419 & 797057 & 1 & 460 & 920914 & 1 \\
\hline 420 & 798513 & 1 & 461 & 922121 & 1 \\
\hline 421 & 799595 & 1 & 462 & 927784 & 1 \\
\hline 422 & 800570 & 1 & 463 & 938968 & 1 \\
\hline 423 & 806578 & 1 & 464 & 952872 & 1 \\
\hline 424 & 812266 & 1 & 465 & 952946 & 1 \\
\hline 425 & 812914 & 1 & 466 & 954626 & 1 \\
\hline 426 & 828395 & 1 & 467 & 956619 & 1 \\
\hline 427 & 829700 & 1 & 468 & 957780 & 1 \\
\hline 428 & 835732 & 1 & 469 & 962477 & 1 \\
\hline 429 & 840393 & 1 & 470 & 964048 & 1 \\
\hline 430 & 842469 & 1 & 471 & 964846 & 1 \\
\hline 431 & 851552 & 1 & 472 & 965225 & 1 \\
\hline 432 & 853465 & 1 & 473 & 968234 & 1 \\
\hline 433 & 853486 & 1 & 474 & 972257 & 1 \\
\hline 434 & 853728 & 1 & 475 & 976665 & 1 \\
\hline 435 & 863934 & 1 & 476 & 976715 & 1 \\
\hline 436 & 864783 & 1 & 477 & 979287 & 1 \\
\hline 437 & 865420 & 1 & 478 & 981814 & 1 \\
\hline 438 & 866952 & 1 & 479 & 984582 & 1 \\
\hline 439 & 868135 & 1 & 480 & 994107 & 1 \\
\hline 440 & 870535 & 1 & 481 & 995636 & \\
\hline 441 & 873508 & 1 & & & \\
\hline
\end{tabular}

Nota: Tabela elaborada pela autora. 
O Gráfico 44 apresenta os indivíduos com grau de intermediação na Rede Ipea de 2011 a 2016. A maior parte dos 111 cutpoints, cerca de 79, está localizada no componente principal. Cerca de 32 cutpoints compõem os componentes menores que estão dispersos.

Gráfico 44 - Centralidade de Intermediação dos Atores no Período de 2011 a 2016

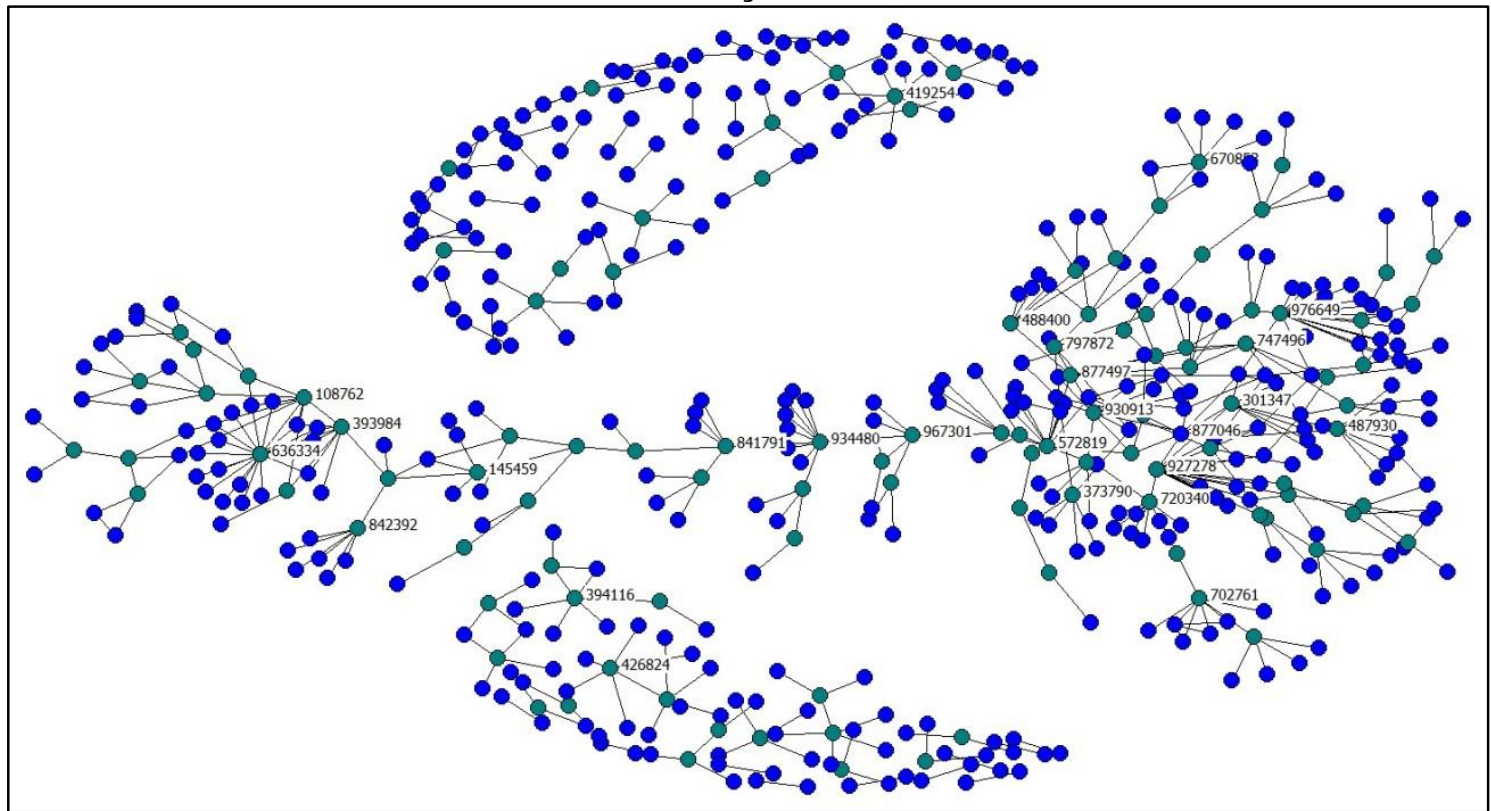

Nota: Elaboração da autora.

Como pode-se verificar, muitos atores, que possuem alto grau nodal, são também atores que ocupam lugares estratégicos na rede em relação à intermediação. Neste quarto período, 111 nós, ou 23,07\% dos atores, fizeram a intermediação de relações de coautoria.

Como visto, houve uma pequena diminuição no percentual de atores que unem blocos na rede do terceiro para o quarto período. Neste quarto período, o percentual de atores que fizeram a intermediação de relações de coautoria foi de $23,07 \%$, e no terceiro período foi de $24,57 \%$.

Pode-se considerar que os 111 atores com grau de intermediação igual a 1, listados na tabela 18 abaixo, contribuem para que a rede seja menos fragmentada neste período. 
Tabela 31 - Centralidade de Intermediação dos Atores no Período de 2011 a 2016

\begin{tabular}{|c|c|c|c|c|c|c|c|c|}
\hline & Ator & Grau de intermediação & & Ator & Grau de intermediação & & Ator & Grau de intermediação \\
\hline 1 & 108762 & 1 & 51 & 488400 & 1 & 101 & 941310 & 1 \\
\hline 2 & 113844 & 1 & 52 & 490550 & 1 & 102 & 946030 & 1 \\
\hline 3 & 117786 & 1 & 53 & 498733 & 1 & 103 & 946122 & 1 \\
\hline 4 & 145459 & 1 & 54 & 520056 & 1 & 104 & 950403 & 1 \\
\hline 5 & 151460 & 1 & 55 & 528426 & 1 & 105 & 953839 & 1 \\
\hline 6 & 164690 & 1 & 56 & 566812 & 1 & 106 & 966918 & 1 \\
\hline 7 & 167673 & 1 & 57 & 572819 & 1 & 107 & 967301 & 1 \\
\hline 8 & 167917 & 1 & 58 & 586544 & 1 & 108 & 972396 & 1 \\
\hline 9 & 174769 & 1 & 59 & 602864 & 1 & 109 & 976649 & 1 \\
\hline 10 & 184643 & 1 & 60 & 605962 & 1 & 110 & 984357 & 1 \\
\hline 11 & 185115 & 1 & 61 & 606476 & 1 & 111 & 986022 & 1 \\
\hline 12 & 192945 & 1 & 62 & 619491 & 1 & & & \\
\hline 13 & 193060 & 1 & 63 & 630702 & 1 & & & \\
\hline 14 & 194293 & 1 & 64 & 636334 & 1 & & & \\
\hline 15 & 206032 & 1 & 65 & 646994 & 1 & & & \\
\hline 16 & 215437 & 1 & 66 & 648775 & 1 & & & \\
\hline 17 & 244208 & 1 & 67 & 649954 & 1 & & & \\
\hline 18 & 260039 & 1 & 68 & 651682 & 1 & & & \\
\hline 19 & 267241 & 1 & 69 & 670853 & 1 & & & \\
\hline 20 & 277062 & 1 & 70 & 675697 & 1 & & & \\
\hline 21 & 282172 & 1 & 71 & 679564 & 1 & & & \\
\hline 22 & 301347 & 1 & 72 & 681599 & 1 & & & \\
\hline 23 & 340503 & 1 & 73 & 690817 & 1 & & & \\
\hline 24 & 347180 & 1 & 74 & 695567 & 1 & & & \\
\hline 25 & 350210 & 1 & 75 & 699035 & 1 & & & \\
\hline 26 & 362013 & 1 & 76 & 699547 & 1 & & & \\
\hline 27 & 370102 & 1 & 77 & 702761 & 1 & & & \\
\hline 28 & 372571 & 1 & 78 & 705971 & 1 & & & \\
\hline 29 & 373790 & 1 & 79 & 714134 & 1 & & & \\
\hline 30 & 375340 & 1 & 80 & 720340 & 1 & & & \\
\hline 31 & 377713 & 1 & 81 & 747496 & 1 & & & \\
\hline 32 & 382512 & 1 & 82 & 750189 & 1 & & & \\
\hline 33 & 392513 & 1 & 83 & 763534 & 1 & & & \\
\hline 34 & 393519 & 1 & 84 & 771648 & 1 & & & \\
\hline 35 & 393984 & 1 & 85 & 784025 & 1 & & & \\
\hline 36 & 394116 & 1 & 86 & 797872 & 1 & & & \\
\hline 37 & 400711 & 1 & 87 & 806316 & 1 & & & \\
\hline 38 & 419254 & 1 & 88 & 812231 & 1 & & & \\
\hline 39 & 420479 & 1 & 89 & 830622 & 1 & & & \\
\hline 40 & 425432 & 1 & 90 & 835612 & 1 & & & \\
\hline 41 & 426824 & 1 & 91 & 841685 & 1 & & & \\
\hline 42 & 436608 & 1 & 92 & 841791 & 1 & & & \\
\hline 43 & 439292 & 1 & 93 & 842392 & 1 & & & \\
\hline 44 & 446305 & 1 & 94 & 858051 & 1 & & & \\
\hline 45 & 450545 & 1 & 95 & 858299 & 1 & & & \\
\hline 46 & 465852 & 1 & 96 & 877497 & 1 & & & \\
\hline 47 & 467337 & 1 & 97 & 894295 & 1 & & & \\
\hline 48 & 476715 & 1 & 98 & 927278 & 1 & & & \\
\hline 49 & 481457 & 1 & 99 & 930913 & 1 & & & \\
\hline 50 & 487930 & 1 & 100 & 934480 & 1 & & & \\
\hline
\end{tabular}

Nota: Tabela elaborada pela autora. 
Dos 11 atores que se acompanhou, desde o primeiro período, constatou-se que 5 atores "desapareceram" da rede no terceiro período. Dos 6 atores que permanecem em atividade na rede do primeiro até o terceiro período, apenas 1 ator, o 858299 se manteve ativo na rede até o quarto período.

Tabela 32 - Atores que Permaneceram Ativos na Rede nos 3 Períodos

\begin{tabular}{|c|c|c|c|c|c|}
\hline & Atores & Grau_10_período & Grau_2o_período & Grau_3o_período & Grau_40_período \\
\hline 1 & 572717 & 4 & 5 & 8 & $\mathbf{0}$ \\
\hline 2 & 858299 & 3 & 7 & 16 & $\mathbf{4}$ \\
\hline 3 & 119871 & 2 & 1 & 2 & $\mathbf{0}$ \\
\hline 4 & 277323 & 1 & 4 & 17 & $\mathbf{0}$ \\
\hline 6 & 365708 & 1 & 1 & 3 & $\mathbf{0}$ \\
\hline 9 & 520744 & 1 & 3 & 1 & $\mathbf{0}$ \\
\hline
\end{tabular}

Nota: Tabela elaborada pela autora.

Os outros 5 atores restantes se mantiveram inativos no último período, ou seja, não estabeleceram relações de coautoria e, portanto, não obtiveram grau de centralidade. São eles: $572717 ; 119871 ; 277323 ; 365708$ e 520744.

Ao somar o grau nodal cumulativo do único ator que permaneceu na rede nos 4 períodos analisados, viu-se que o grau nodal do ator 858299 é igual a 30.

\section{Tabela 33 - Ator que Permaneceu Ativos na Rede nos 4 Períodos}

\begin{tabular}{|c|c|c|c|}
\hline & Ator & Soma nos 3 periodos & Soma nos 4 periodos \\
\hline 1 & 858299 & 26 & 30 \\
\hline
\end{tabular}

Nota: Tabela elaborada pela autora. 


\section{CONCLUSÕES}

a) A descoberta da série temporal apresenta para o Ipea um importante indicador de sua produção e desempenho nos últimos 37 anos. A variável nomeada "Produção Anual de Textos para Discussão do Ipea" (PATD) pode ser utilizada como "Proxy de desempenho" e abre caminhos para o estudo de outras variáveis que possam interferir na PATD. Como contribuição para a Bibliometria ou Cientometria, a pesquisa deixa o exemplo de que os dados quantitativos de grandes séries temporais de periódicos nacionais, muitas vezes desprezado pela área da ciência que mede a ciência, podem servir de gerar séries temporais e Proxys de pesquisa que podem ser exploradas tanto pela Econometria quanto pela Gestão Pública.

b) Do ponto de vista da comunicação científica, no que se refere a contribuição da pesquisa para a discussão acerca da "qualidade" e do "papel" do TD como canal de comunicação científica, a pesquisa mostrou, que, indiscutivelmente, o TD é muito relevante para o desenvolvimento econômico e social do Brasil. Dentre 52 características levantadas, os TDs preenchem 44 requisitos. Concluímos que a série TD atende aos principais requisitos ou critérios de qualidade exigidos para a certificação e aceite do conhecimento pela comunidade científica, no entanto, se considerarmos apenas as métricas quantitativas de avaliação da ciência baseadas nas citações, o principal periódico do Ipea precisará percorrer ainda um longo caminho, se sua meta for alcançar o "prestígio" e a "centralidade" dos grandes periódicos internacionais da área de Economia. Nesse ponto, concluímos que os esforços do Ipea em relação aos TD não seriam muito diferentes do esforço de milhares de periódicos científicos brasileiros em Economia, Administração Pública e demais áreas, que, apesar de todos os indispensáveis esforços relativos a busca da qualidade, ainda não se destacaram para a chamada zona central da ciência, ao contrário, dividem a mesma zona periférica da ciência onde o TD se encontra, que é reservada a produção cientifica dos países em desenvolvimento.

Como sabemos, o TD é pontuado em B1, pelo sistema Qualis/Capes, em áreas Interdisciplinares. Por outro lado, apesar de ainda não ser atribuída nota aos TD pelo mesmo Sistema Qualis/Capes, para a área de Economia, acreditamos que o aprofundamento do estudo das questões relacionadas ao aumento da "qualidade dos TD como periódico científico", pode trazer benefícios para o aperfeiçoamento do TD como 
importante canal de comunicação científica na área de Economia pública. A complementação desta pesquisa por meio da aplicação de outros métodos de coleta de dados, como por exemplo, a aplicação de questionários para levantarmos e entendermos em detalhes as "críticas" da "Comunidade científica brasileira em Economia" aos TD, para que um plano de aperfeiçoamento e resolução sistemática de problemas possa contribuir para o aumento da qualidade dos estudos e pesquisas publicados na série periódica e consequentemente, contribua para sua melhor avaliação pela comunidade cientifica.

c) Como resultado, considerando o contexto mundial do Acesso Aberto, a pesquisa levounos a concluir que o TD atende ao principal requisito da Comunicação Cientifica para o próximo século e se encaixa no "Novo princípio da Inovação" estabelecido para os países da União Europeia. O Acesso Aberto ao conhecimento científico mudará completamente o panorama da Comunicação Científica a partir de 2020, quando todos os países da União Europeia anunciarão a abertura dos resultados de pesquisa de seus bancos de dados, de forma gratuita e irrestrita, para livre para uso e reuso da humanidade. Nesse sentido, concluímos que os Textos para Discussão (TD) do Ipea, por estarem disponíveis em Acesso Aberto, contribuem para a reutilização dos resultados das pesquisas e estudos produzidos pelo instituto e financiadas com recursos públicos. Ademais, a reutilização ótima dos resultados do Ipea atendem ao requisito fundamental para o chamado "Novo Princípio da Inovação".

A orientação aprovada por ministros das áreas de ciência, tecnologia, educação, indústria e comércio dos 28 países-membros, não tem força de lei, mas revela a importância de requisito para a divulgação de resultados de pesquisa financiadas com recursos públicos. Segundo Sander Dekker (Presidency of Netherlands State Secretary for Education, Culture and Science), os estados membros da União Europeia querem alcançar a reutilização ideal dos resultados das pesquisas. 
d) Como contribuição para as áreas de Propriedade Intelectual e Biblioteconomia, os resultados da pesquisa evidenciam a importância da atribuição de autoria ou coautoria pessoal, em detrimento da autoria entidade na publicação de resultados de estudos e pesquisas. Concluímos que o estudo das redes dos institutos de pesquisa nacionais e o estudo das redes de colaboração na Administração Pública Brasileira (APB), a partir da análise de coautoria, dependem da identificação precisa dos seus criadores intelectuais. Os dados resultantes da análise de coautoria são seguros e devem ser explorados para os estudos de redes de pesquisa no Brasil.

e) Como contribuição para as áreas de Bibliometria ou Cientometria, mais especificamente as áreas que estudam a tendência de aumento de colaborações em pesquisa, ou tendência à Multiautoria, a pesquisa conclui que o periódico brasileiro TD do Ipea segue a tendência de aumento de colaborações em pesquisa, ou tendência à Multiautoria, como observado por diversas pesquisas em diferentes áreas do conhecimento.

f) Como contribuição para as áreas de Bibliometria ou Cientometria, mais especificamente as áreas que estudam o aumento na produção científica, a série periódica TD do Ipea, até então desprezada pelas áreas, mostra o aumento da produção de estudos e pesquisas em função de uma série de variáveis. O estudo das variáveis que influenciaram os picos e as quedas observadas na PATD pode servir para entendermos o desempenho de outros institutos de pesquisa nacionais e fornecer dados importante para o investimento em pesquisa no Brasil. Nesse sentido, concluímos que periódicos nacionais, tais como os TD do Ipea, que não têm relevância no contexto mundial da Comunicação Científica, fornecem importantes indicadores para entendermos nosso desempenho em ciência e tecnologia e pesquisa e desenvolvimento.

f) Como contribuição para as áreas de ARS, o banco de dados construído a partir da série periódica do Ipea, contribui para o estudo de redes de pesquisa em caráter longitudinal. Para o Ipea, os resultados práticos da pesquisa descortinam a dinâmica de sua rede ao longo dos 37 anos, cujos resultados podem ser utilizados para a implementação de estratégias pela instituição. A identificação dos atores centrais e dos que possuem grau 
de intermediação são resultados iniciais, que abrem caminho para o aprofundamento do estudo da rede de pesquisa do Ipea. 


\section{REFERÊNCIAS BIBLIOGRÁFICAS}

ABADAL, Ernest; RIUS, Luís. Revistas científicas digitales: características e indicadores. Revista de Universidad y Sociedad del Conocimiento, v. 3, n.1, abril 2006.

ABADAL, Ernest. Retos de las revistas en acceso abierto: cantidad, calidad y sostenibilidad económica. Hipertext.net, n.10, 2012.

ABT, H. A. (2007). The future of single-authored papers. Scientometrics, 73(3), 353358.

ALBORNOZ, Mario. Ciencia, tecnología e innovación para el desarrollo y la cohesión social. Madrid: Organización de Estados Iberoamericanos para la Educación, la Ciencia y la Cultura - OEI, 2012.

ALBORNOZ, Mario. Desarrollo y políticas públicas en ciencia y tecnología en América Latina. RIPS. Revista de Investigaciones Políticas y Sociológicas, n. 8, 2009.

ALBORNOZ, Mario. Indicadores en ciencia y tecnología. Redes, v. 1, n. 1, p. 133- 144, septiembre, 1994.

ALL European scientific articles to be freely accessible by 2020: Europe makes a definitive choice for open access by 2020. Press release. May. 2016.

AGUIAR, A.C. Informação e atividades de desenvolvimento científico, tecnológico e industrial: tipologia proposta com base em análise funcional. Ci. Inf., Brasília, 20(1):715, jan./jun. 1991. Disponível em: < http://revista.ibict.br/ciinf/article/download/409/409>. Acesso em: fev. 2016.

BEM-DAVID, J. O papel do cientista na sociedade: um estudo comparativo. São Paulo: Pioneira: EdUSP, 1974.

BARBOSA, M. T. S.; BYINGTON, M. R. L.; STRUCHINER, C. J. Modelos dinâmicos e redes sociais: revisão e reflexões a respeito de sua contribuição para o entendimento da epidemia do HIV. Cad. Saúde Pública, 2000, v.16, supl.1, p.S37-S51. ISSN 0102-311X.

BARRÉ, R. (2005). S\&T indicators for policy making in a change science-Society relationship. In H. F. Moed, W. Glänzel, \& U. Schmoch (Eds.), Handbook of quantitative science and technology research (pp. 115-132). Berlin: Springer.

BASTOS, A. V.; LOIOLA, E.; REGIS, H. P. Análise das redes sociais em contextos organizacionais. Salvador: EDUFBA, 2015. 587 p.

BATISTA, F. F.et al. Casos reais de implantação do Modelo de Gestão do Conhecimento para a Administração Pública Brasileira. Texto para Discussão nº 1941. Ipea. 2014.

BOAI. Budapest Open Access Initiative. Spanish Translation. Disponível em: <http://www.opensocietyfoundations.org/openaccess/translations/spanish-translation>. Acesso em: 30 out. 2013. 
BORGATTI, S.P., Everett, M.G. and Freeman, L.C. 2002. Ucinet for Windows: Software for Social Network Analysis. Harvard, MA: Analytic Technologies, 2002.

BORGATTI, S.P., 2002. NetDraw Software for Network Visualization. Analytic Technologies: Lexington, KY.

BRAGA, G.M; OBHERHOFER, A. Diretrizes para a avaliação de periódicos científicos e técnicos brasileiros. Rev.Lat.Doc.,v.2, n.1, p. 27-31, ene./jun. 1982.

CAMPELLO, Bernadete Santos; CAMPOS, Carlita Maria. Fontes de informação especializada: características e utilização. 2. ed. Belo Horizonte: Ed. UFMG, 1993.

CARVALHO, W. A. Fundação do IPEA: Formação, Desenvolvimento e Impasses, IPEA, 1996.

CASTRO, C. de M. Há produção científica no Brasil? In: SCHWARTZMAN, S., CASTRO, C. de M. (Org.). Pesquisa universitária em questão. Campinas: UNICAMP, 1986. 232 p. p. $190-224$.

CHRISTOVÃO, Heloisa Tardin; BRAGA, Gilda Maria. Ciência da Informação e Sociologia do conhecimento científico: a intertematicidade plural. Transinformação, Campinas, v. 9, n. 3, p. 33-45, set./dez. 1997.

CORREIA, Ana Maria Ramalho. O papel das bibliotecas digitais de literatura cinzenta os repositórios de eprints - na comunicação científica. In: Segundas Jornadas de Bibliotecas Digitais, 2001.

COSTA, Sely. Mudanças no processo de comunicação científica: o impacto do uso de novas tecnologias. In: PASSOS, E. J. L.; MUELLER, S.P. M. (Org.). Comunicação científica. Brasília: Departamento de Ciência da Informação da Universidade de Brasília, 2000. (Estudos avançados em Ciência da Informação, 1).

COSTA, Veruska da Silva. Os monopólios do conhecimento. In. Palavra de Especialista: Observatório Ipea de Gestão do Conhecimento. 2015. Disponível em: http://www.ipea.gov.br/observatorio/palavra-de-espcialista/114-veruska-da-silvacosta/241-os-monopolios-do-conhecimento

DARWS, Stuart. Virtually there: Open Access and the online growth of Pacific Dissertations and Theses. The Contemporary Pacific, v. 24, n. 2, 2012.

DE MEIS, L. et. Al. The growing competition in Brazilian Science: rites of passage, stress and burnout. Brazilian Journal of Medical and Biological Research. V. 36(9), 2003. p. 1135-1141.

DI CHIARA, I. G. [et. al.]. As citações como base da rede social egocêntrica: o artigo citado e suas conexões. In: Encontro Nacional de Pesquisa em Ciência da Informação ENANCIB, 7., 2006, Marília. Anais... Marília: FFC/UNESP, 2006. p. 441- 452.

EDGE, D. Quantitative Measures of Communication in Science: a Critical Review. History of Science, vol.17, pp.102-134. 1979. 
EVERETT, M. G.; BORGATTI, S. P. Extending Centrality In: CARRINGTON, P.; SCOTT, J.; WASSERMAN, S. (organizadores): Models and Methods in Social Network Analysis. New York: Cambridge Press, 2005.

FREEMAN, L. C. Centrality in Social Networks: conceptual clarification. Social Networks, v. 1, p. 215-239, 1979.

GARFIELD, E. Citation indexing for studying science. Nature, s.1., v.227, p. 669-671, Aug. 1970.

GARVEY, W. D. Communication: the essence of science; facilitating information among librarians, scientists, engineers and students. Oxford: Pergamon, 1979. 332 p.

GINSPARG, P. Electronic publishing in science. 1996.

GRANOVETTER, M. S. The strength of weak ties. American Journal of Sociology, Chicago, v.78, n.6, p.1360-1380, 1973.

GUÉDON, Jean-Claude. Acesso Aberto e divisão entre ciência predominante e ciência periférica. In: FERREIRA, Sueli Mara; TARGINO, Maria das Graças (Orgs.). Acessibilidade e visibilidade de revistas científicas eletrônicas. São Paulo: Editora São Paulo, 2010.

GUJARATI, D. N. Econometria Básica, 3. Ed. Pearson Education do Brasil, 2000.

HARARY, F. Graph theory. Massachusetts: Addison-Wesley, 1972. 274 p. (AddisonWesley Series in Mathematics).

HAYASHI, M. C. P. I. et al. Um estudo bibliométrico da produção científica sobre a educação jesuítica no Brasil colonial. Biblios, año 8, n.27, Ene, mar_2007, p. 01-18.

HAYASHI, M. C. P. I. et al. Análise de redes de coautoria na produção científica em educação especial.Liinc em Revista, Rio de Janeiro, v.4, n.1, mar_2008. p. 84-103.

HARNAD, Stevan. A Subversive Proposal. In: OKERSON, Ann; ODONNEL, James (Ed.). Scholarly Journals at the Crossroads: a subversive proposal for electronic publishing. Washington, DC: Association of Research Libraries, 1995.

INSTITUTO de Pesquisa Econômica Aplicada (Ipea). TD 1000. Edição especial, com resenhas por áreas temáticas. Brasília: Ipea, 2004.

INSTITUTO de Pesquisa Econômica Aplicada (Ipea). TD 2000: pesquisas e propostas. Edição especial. Brasília: Ipea, 2014.

ISSN. Manual ISSN de catalogación. Paris, ISSN International Centre, 2010.

KING, D. A. (2004). The scientific impact of nations. Nature, 430, 311-316.

KYRILLIDOU, Martha; MORRIS, Shaneka; ROEBUCK, Gary (Comp.). ARL Statistics 2010-2011. Washington: ARL, 2011. 
LAGOZE, Carl; VAN DE SOMPEL, Herbert. The making of the Open Archives Initiative Protocol for Metadata Harvesting. Emerald, v. 21, n. 2, p. 118-128, 2003.

The Open Archives Initiative: Building a low-barrier interoperability framework. 2001. Proceedings... Roanoke VA: jun. 24-28, 2001, p. 54-62.

LE COADIC, Y. F. A ciência da informação. Tradução de Maria Yêda F. S. de Figueira Gomes. Brasília, DF: Briquet de Lemos/Livros, 2004. 124 p.

LOUREIRO, M. R. Formação de Elites Dirigentes no Brasil: o papel das Instituições de Ensino e Pesquisa Econômica Aplicada. Relatório de Pesquisa no. 18/1997, EAESP/FGV/NPP - Núcleo de Pesquisa e Publicações, Fundação Getúlio Vargas, 1997.

LOUREIRO, M. R., e Abrucio, F. L. Política e burocracia no presidencialismo brasileiro: o papel do Ministério da Fazenda no primeirogoverno Fernando Henrique Cardoso. Revista Brasileira de Ciências Sociais, 14(41), 1999. p. 69-89.

MARTELETO, R. M. Análise de Redes Sociais - aplicação nos estudos de transferência da informação. Cia Inf., v. 30, n. 1, p. 71-81, 2001.

MARTELETO, R. M.; SILVA, A. B. de O. Redes e capital social: o enfoque da informação para o desenvolvimento local. Cia Inf., Brasília, v.33, n.3, p.41-49, set./dez. 2004.

MAYOR, F. Oppening Adress. Joint ICSU Press/Unesco Expert Conference on Electronic Publishing in Science, Paris, p.19-23, feb. 1996.

MEADOWS, A. J. A comunicação científica. Brasília: Briquet de Lemos Livros, 1999. $268 \mathrm{p}$.

MENZEL, H. Scientific communication: five themes from social science research. American Psychologist, v.21, n.10, p.999-1004, 1966.

MOLINA, J. L. El estúdio de las redes personales: contribuciones, métodos y perspectivas. Empiria, v.10, p.71-106, jul.-dec.2005.

MORAVCSIK, M. J. In the Beholder's Eye: a Possible Reinterpretation of Velho's Results on Brazilian Agricultural Research. Scientometrics, vol.11, nº1-2, pp.53-57. 1987.

NABOUT, et al. Publish (in a group) or perish (alone): the trend fron songle- to multiauthorship in biological papers. Scientometrics, v. 102, 2015. 357-364 p.

NONAKA, I.; TAKEUCHI, H. The knowledge-creating company. Oxford: Oxford University Press, 1995.

OECD - ORGANISATION FOR ECONOMIC CO-OPERATION AND DEVELOPMENT. Innovation and growth: chasing a moving frontier. Paris: OECD Publishing, 2010a. 
. Measuring innovation: a new perspective. Paris: OECD Publishing, $2010 \mathrm{~b}$.

OLIVEIRA, S. C. Análise de redes sociais em grupos de pesquisa de gestão do conhecimento da Plataforma Lattes. 2006. 36 f. Trabalho de Conclusão de Curso (Graduação em Biblioteconomia e Ciência da Informação) -Universidade Federal de São Carlos, São Carlos, 2006.

OTTE, E; ROUSSEAU, R. Social network analysis: a powerful strategy, also for information sciences. Journal of Information Science, Cambridge, v. 28, n. 6, p. 441-453, 2002.

PRICE, Derek John de Solla. A ciência desde a Babilônia. Belo Horizonte: Itatiaia, 1976. $189 \mathrm{p}$.

RODRIGUES, L. C.; MUSTARO, P. N. Levantamento de características referentes à análise de redes sociais nas comunidades virtuais brasileiras de jogos on-line. In: V Brazilian Symposium on Computer Games and Digital Entertainment, 2006, Recife.

ROSSONI, L.; HOCAYEN-DA-SILVA, A.; FERREIRA JR, I. Aspectos Estruturais da Cooperação entre Pesquisadores no Campo de Ciência e Tecnologia: análise das redes entre instituições no Brasil In: Anais do XXIX Simpósio de Gestão da Inovação Tecnológica, Gramado: ANPAD, 2006.

SCHEKMAN, Randy. How journals like Nature, Cell and Science are damaging science. The Guardian, Dec. 2013. Disponível em:https://www.theguardian.com/commentisfree/2013/dec/09/how-journals-naturescience-cell-damage-science

SCOTT, J. Social Network Analysis: a handbook. 2a ed., London: Sage Publications, 2000.

SILVA, A. B. de O. [et. al.]. Estudo da rede de coautoria e da interdisciplinaridade na produção científica com base nos métodos de análise de redes sociais: avaliação do caso do programa de pós-graduação em ciência da informação - PPGCI/UFMG. Enc. Bibli: R. Eletr. Bibliotecon. Ci. Inf., Florianópolis, n. esp., $1^{\text {o }}$ sem. 2006 a.

Redes de coautoria dos professores da ciência da informação: um retrato da colaboração científica dessa disciplina no Brasil. In: Encontro Nacional de Pesquisa em Ciência da Informação- ENANCIB, 7., 2006, Marília. Anais... Marília: FFC/UNESP, 2006b. p. 441-452.

SILVEIRA, S. A. Propriedade intelectual, monopólio do conhecimento e software livre. In: Gestão do conhecimento: uma estratégia empresarial. Brasília: JJ, 2006. 348 p.

SINDICATO Nacional dos Docentes das Instituições de Ensino Superior (ANDES-SN). Desvio ideológico na concepção do mérito acadêmico. In. Revista Dossiê Nacional Precarização II. Dez. de 2013.

SPINAK, Ernesto. Diccionario enciclopedico de bibliometria, cienciometria $e$ informetria. Caracas: UNESCO, 1996. 245 p. 
Indicadores cienciométricos. Ciência da Informação, Brasília, v. 27, n. 2, p. 141148, maio/ago. 1998.

STIGLITZ, Joseph E. Economics of the public Sector, (3rd ed.), Norton, 1999.

STUMPF, I. R. C. Passado e futuro das revistas científicas. Ciência da Informação, v.25, n.3, 1996.

Revistas universitárias brasileiras: barreiras na sua produção. Transinformação, Campinas, v. 9, n. 1, p. 45-57, jan./abr. 1997.

.Periódicos científicos. In: Documentos ABEBD 8, 1998, Porto Alegre. Anais. Porto Alegre: Associação Brasileira de Ensino em Biblioteconomia e Documentação, 1998.

Avaliação das revistas de Comunicação pela comunidade acadêmica da área. Em Questão, Porto Alegre, v.9, n.1, p.25-38, jan./jun.2003.

Avaliação de originais nas revistas científicas: uma trajetória em busca do acerto. In: FERREIRA, S; TARGINO, M. Preparação de revistas científicas: teoria e prática. São Paulo: Reichmann \& Autores, 2005. p. 103-122.

VALÉRIO, P. M. O periódico científico. In: Curso de Atualização sobre Avaliação do Trabalho Científico.Petrópolis: ABEC, 2005.

VAN DE SOMPEL, H.; LAGOZE, C. The Santa Fe convention of the Open Archives Iniciative. Dlib Magazine, v. 6, n. 2, Feb. 2000. Disponível em: <http://www.dlib.org/dlib/february00/vandesompel-oai/02vandesompel-oai.html>. Acesso em: jul. 2016.

VELHO, L. Science on the Periphery: a Study of the Agricultural Scientific Community in Brazilian Universities. Tese de Doutorado apresentada a Universidade de Sussex, Inglaterra. 1985.

The meaning of citation in the context of a scientifically peripheral country. Scientometrics, v.9, n.1-2, p.71-89, 1986.

The Author and the Beholder: How Paradigm Commitments Can Influence the Interpretation of Research Results", Scientometrics, vol.11, nº1-2, pp.59-70. 1987.

Indicadores científicos: aspectos teóricos y metodológicos e impactos en la política científica. In: MARTINEZ, E.; ALBORNOZ, M. (Ed.). Indicadores de ciencia y tecnología: estado del arte e perspectivas. Caracas : Nova Sociedad, 1998.

Cuidado com os rankings científicos: por que deve-se temer as avaliações sobre quem produz mais ciência, e como essas avaliações discriminam o Terceiro Mundo.2014. Disponível em: http://www.prometeu.com.br/bb-lea.asp. 
WASSERMAN, S.; FAUST, K. Social network analysis: methods and applications. Cambridge: Cambridge University Press, 1999. 857p.

WEISMAN, Herman M. Information systems, services and centers. New York: Washington : Wiley-Becker-Hayes Publications, 1972. 165p.

WELLMAN, B. An electronic group is virtually a social network. In: KIESLER, S. Culture of the Internet. Hillsdale, NJ: Lawrence Erlbaum, p. 179-205, 1997.

WELLMAN, B. For a social network analysis of computer networks: a sociological perspective on collaborative work and virtual comunity. In: Proceedings of SIGCPR/SIGMIS. Denver, CO: ACM Press, 1-11, 1996. 


\section{APÊNDICES}

\section{APÊNDICE A: TABELA DE CODIFICAÇÃO DE AUTORES}

\begin{tabular}{|c|c|c|}
\hline & Autor & Código \\
\hline 1 & Abrahão, Jorge & 770954 \\
\hline 2 & Abramovay, Ricardo & 515289 \\
\hline 3 & Abreu, Luiz Eduardo & 660593 \\
\hline 4 & Abreu, Marcelo de Paiva & 642405 \\
\hline 5 & Abreu, Maria Aparecida Azevedo & 674154 \\
\hline 6 & Abreu, Rafael & 164875 \\
\hline 7 & Acioly, Luciana & 966730 \\
\hline 8 & Afonso, José Roberto & 502447 \\
\hline 9 & Afonso, Luís Eduardo & 273477 \\
\hline 10 & Aguiais, Edilson Gonçalves de & 957780 \\
\hline 11 & Aguiar, Danilo Rolim Dias de & 497562 \\
\hline 12 & Aguiar, Josiana & 829700 \\
\hline 13 & Alain, Marcelo & 584283 \\
\hline 14 & Albuquerque, Débora de Souza Leão & 167917 \\
\hline 15 & Albuquerque, José Augusto Guilhon & 449152 \\
\hline 16 & Albuquerque, Pedro & 222079 \\
\hline 17 & Albuquerque, Roberto C. de & 453555 \\
\hline 18 & Aldigueri, Daniel Rodrigues & 913069 \\
\hline 19 & Alencar, Ane & 264364 \\
\hline 20 & Alencar, Joana Luiza Oliveira & 266442 \\
\hline 21 & Alexandre, Michel & 566319 \\
\hline 22 & Almeida Junior, Gilberto Rezende de & 184217 \\
\hline 23 & Almeida Neto, Antonio Augusto de & 647430 \\
\hline 24 & Almeida, Acir & 793410 \\
\hline 25 & Almeida, Alexandre Nunes de & 810820 \\
\hline 26 & Almeida, Anna Luiza Ozorio de & 873256 \\
\hline 27 & Almeida, Celia & 102602 \\
\hline 28 & Almeida, Débora Rezende de & 448942 \\
\hline 29 & Almeida, Glaudiane & 155146 \\
\hline 30 & Almeida, Guilherme Bacha de & 391402 \\
\hline 31 & Almeida, Heitor & 649076 \\
\hline 32 & Almeida, Manoel Bosco de & 463216 \\
\hline 33 & Almeida, Mansueto Facundo & 771127 \\
\hline 34 & Almeida, Marcio Wohlers de & 889721 \\
\hline 35 & Almeida, Nathália Filgueiras de & 755747 \\
\hline 36 & Almeida, Raquel Filgueiras de & 539449 \\
\hline 37 & Almeida, Rita & 202043 \\
\hline 38 & Almeida, Vinícius Lima de & 532418 \\
\hline
\end{tabular}




\begin{tabular}{|c|c|c|}
\hline 39 & Almeida, Vivian Vicente de & 740107 \\
\hline 40 & Alvarenga, Gustavo & 551725 \\
\hline 41 & Alves Jr., Antônio José & 597311 \\
\hline 42 & Alves, Adriana Freitas & 404800 \\
\hline 43 & Alves, Edgard Luiz Gutierrez & 841404 \\
\hline 44 & Alves, José Eustáquio Diniz & 549265 \\
\hline 45 & Alves, Paloma Palmieri & 680028 \\
\hline 46 & Alves, Patrick Franco & 347180 \\
\hline 47 & Alves, Yann Le Boulluec & 168696 \\
\hline 48 & Amadeo, Edward J. & 793415 \\
\hline 49 & Amancio, Andrea & 362728 \\
\hline 50 & Amaral Filho, Jair do & 379629 \\
\hline 51 & Amaral Sobrinho, José & 453729 \\
\hline 52 & Amaral, Lucas Alves & 919875 \\
\hline 53 & Amaral, Marcelo Rubens do & 631962 \\
\hline 54 & Amarante, José Carlos Albano do & 824890 \\
\hline 55 & Amendola, Elaine & 159550 \\
\hline 56 & Amitrano, Cláudio Roberto & 203211 \\
\hline 57 & Amorim, Brunu & 108214 \\
\hline 58 & Amorim, Ricardo L. C. & 586859 \\
\hline 59 & Amparo, Paulo Pitanga do & 425134 \\
\hline 60 & Anastasia, Fátima & 362013 \\
\hline 61 & Andersen, Lykke E. & 319656 \\
\hline 62 & Anderson, Patrícia & 677661 \\
\hline 63 & Andrade, Bárbara Caballero de & 454642 \\
\hline 64 & Andrade, Carla Coelho de & 648775 \\
\hline 65 & Andrade, Eron Campos Saraiva de & 565981 \\
\hline 66 & Andrade, Everaldo Gaspar Lopes de & 478956 \\
\hline 67 & Andrade, Israel de Oliveira & 488400 \\
\hline 68 & Andrade, Joaquim & 888682 \\
\hline 69 & Andrade, Sandro Canesso de & 381873 \\
\hline 70 & Andrade, Thompson Almeida & 569541 \\
\hline 71 & Andreazzi, Maria de Fátima Siliansky de & 893050 \\
\hline 72 & Ansiliero, Graziela & 157074 \\
\hline 73 & Aquino, Luseni & 757305 \\
\hline 74 & Araújo Júnior, Ignácio Tavares de & 337467 \\
\hline 75 & Araújo Junior, José Tavares de & 447873 \\
\hline 76 & Araújo, Bruno César & 747496 \\
\hline 77 & Araújo, Débora Cristina & 518112 \\
\hline 78 & Araújo, Eliane & 372709 \\
\hline 79 & Araújo, Emerson Rildo de & 962942 \\
\hline 80 & Araújo, Erika Amorim & 644081 \\
\hline 81 & Araújo, Herton Ellery & 808588 \\
\hline
\end{tabular}




\begin{tabular}{|c|c|c|}
\hline 82 & Araújo, João Lizardo de & 610369 \\
\hline 83 & Araújo, Kátia & 290924 \\
\hline 84 & Araujo, Lucas Speranza & 451184 \\
\hline 85 & Araújo, Maria do Socorro de & 292242 \\
\hline 86 & Araújo, Paulo Fernando Cidade de & 870231 \\
\hline 87 & Araújo, Tatiana Daré & 432436 \\
\hline 88 & Araújo, Thiago Costa & 328710 \\
\hline 89 & Araujo, Victor Leonardo de & 436608 \\
\hline 90 & Arbache, Jorge Saba & 722125 \\
\hline 91 & Arbix, Glauco & 523567 \\
\hline 92 & Ardeo, Vagner & 475755 \\
\hline 93 & Arend, Marcelo & 166108 \\
\hline 94 & Arias, Alfonso Rodrigues & 650015 \\
\hline 95 & Arruda, Rosiclé Batista de & 187768 \\
\hline 96 & Asano, Seki & 790379 \\
\hline 97 & Assis, Lucas Rocha Soares de & 571557 \\
\hline 98 & Assis, Milton & 818717 \\
\hline 99 & Aurea, Adriana Pacheco & 405878 \\
\hline 100 & Aurélio, Marcela Meirelles & 759874 \\
\hline 101 & Austin, Duncan & 338820 \\
\hline 102 & Avellar, Ana Paula & 366183 \\
\hline 103 & Ávila, Marcelo de & 373615 \\
\hline 104 & Avritzer, Leonardo & 187930 \\
\hline 105 & Azeredo, Beatriz & 840848 \\
\hline 106 & Azeredo, Luiz Cezar Loureiro de & 409309 \\
\hline 107 & Azevedo, Heloisa & 419254 \\
\hline 108 & Azevedo, João Pedro & 778764 \\
\hline 109 & Azzoni, Carlos & 938968 \\
\hline 110 & Bacchi, Mirian & 815929 \\
\hline 111 & Bacha, Edmar Lisboa & 801358 \\
\hline 112 & Badin, Michelle Ratton Sanchez & 367986 \\
\hline 113 & Baessa, Adriano & 808378 \\
\hline 114 & Bahia, Lígia & 591431 \\
\hline 115 & Bahia, Luiz Dias & 919857 \\
\hline 116 & Bahia, Mônica & 616379 \\
\hline 117 & Balbim, Renato & 797872 \\
\hline 118 & Baltar, Paulo & 675484 \\
\hline 119 & Bandeira, Pedro & 497418 \\
\hline 120 & Barbosa Filho, Nelson H. & 380479 \\
\hline 121 & Barbosa, Ana Luiza & 194293 \\
\hline 122 & Barbosa, Edvaldo Duarte & 739639 \\
\hline 123 & Barbosa, Eni Maria Monteiro & 601585 \\
\hline 124 & Barbosa, Fernando de Holanda & 439292 \\
\hline
\end{tabular}




\begin{tabular}{|c|c|c|}
\hline 125 & Barbosa, Frederico & 766529 \\
\hline 126 & Barbosa, Klênio & 900860 \\
\hline 127 & Barbosa, Luiz Coimbra & 887826 \\
\hline 128 & Barbosa, Maria Alice Cunha & 909456 \\
\hline 129 & Barciotte, Maria Lúcia & 309203 \\
\hline 130 & Barenboim, Igor & 998060 \\
\hline 131 & Barone, Leonardo & 529103 \\
\hline 132 & Barreto, Ângela Rabelo & 509591 \\
\hline 133 & Barreto, Carlos Maurício Guimarães & 130284 \\
\hline 134 & Barreto, Francisco de Oliveira & 217032 \\
\hline 135 & Barros, Alexandre Lahóz Mendonça de & 224200 \\
\hline 136 & Barros, Ana Flávia Granja e & 409477 \\
\hline 137 & Barros, Ana Paula Borba Gonçalves & 364911 \\
\hline 138 & Barros, Fábio Henrique Granja e & 122700 \\
\hline 139 & Barros, Flávio & 169397 \\
\hline 140 & Barros, Geraldo Santana de Camargo & 254817 \\
\hline 141 & Barros, José Roberto Mendonça de & 117719 \\
\hline 142 & Barros, Maria Elizabeth & 353889 \\
\hline 143 & Barros, Pedro Silva & 117786 \\
\hline 144 & Barros, Ricardo Paes de & 244208 \\
\hline 145 & Barros-Platiau, Ana Flávia & 207204 \\
\hline 146 & Barsted, Leila Linhares & 425888 \\
\hline 147 & Barufi, Ana Maria Bonomi & 487982 \\
\hline 148 & Bassi, Camillo de Moraes & 292075 \\
\hline 149 & Bastos, Eliana Teles & 493028 \\
\hline 150 & Bastos, Estêvão Kopschitz Xavier & 899574 \\
\hline 151 & Bastos, Viviane M. & 267241 \\
\hline 152 & Batista, Analia Soria & 240637 \\
\hline 153 & Batista, Edlamar & 905793 \\
\hline 154 & Batista, Fábio Ferreira & 976649 \\
\hline 155 & Batista, Jorge Chami & 943656 \\
\hline 156 & Baumann, Renato & 357202 \\
\hline 157 & Becker, Maria Fernanda & 344277 \\
\hline 158 & Beiner, Bernhard & 255350 \\
\hline 159 & Belik, Walter & 882142 \\
\hline 160 & Beltrão, Kaizô Iwakami & 101448 \\
\hline 161 & Bernardo, Deisiane Pinheiro & 775437 \\
\hline 162 & Bertasso, Beatriz & 278175 \\
\hline 163 & Besen, Gracia Maria Viecelli & 793748 \\
\hline 164 & Bevilaqua, Afonso Sant'Anna & 888415 \\
\hline 165 & Bezchinsky, Gabriel & 125561 \\
\hline 166 & Bezerra, Generosa Sabino Campelo & 954914 \\
\hline 167 & Bezerra, Maria Lucila & 163028 \\
\hline
\end{tabular}




\begin{tabular}{|c|c|c|}
\hline 168 & Bezerra, Renata A. & 749376 \\
\hline 169 & Bhering, Gustavo & 732722 \\
\hline 170 & Biancareli, André M. & 121798 \\
\hline 171 & Biasoto Júnior, Geraldo & 413271 \\
\hline 172 & Bichir, Renata Mirandola & 776161 \\
\hline 173 & Bielschowsky, Ricardo & 409768 \\
\hline 174 & Biron, Lisa & 779107 \\
\hline 175 & Bittar, Mariana & 441794 \\
\hline 176 & Bittencourt, Mirian & 353327 \\
\hline 177 & Bizarria, José Hamilton de O. & 906431 \\
\hline 178 & Blanco, Fernando A. & 461216 \\
\hline 179 & Bonelli, Regis & 572717 \\
\hline 180 & Bonomo, Marco Antonio Cesar & 715208 \\
\hline 181 & Borges, Clarissa & 972257 \\
\hline 182 & Borges, Eduardo Bizzo de Pinho & 777236 \\
\hline 183 & Borges, Luís Maurício Martins & 829055 \\
\hline 184 & Boschi, Renato & 165002 \\
\hline 185 & Boucekkine, Raouf & 450368 \\
\hline 186 & Boueri, Rogério & 206032 \\
\hline 187 & Braga, Alessandra de Almeida & 252414 \\
\hline 188 & Braga, Helson C. & 757056 \\
\hline 189 & Braga, Hugo do Amaral & 127545 \\
\hline 190 & Braga, Julia de Medeiros & 701401 \\
\hline 191 & Bragança, Gabriel & 113844 \\
\hline 192 & Bragança, Guilherme Lima & 864783 \\
\hline 193 & Brandão, Antonio Salazar Pessoa & 115908 \\
\hline 194 & Brasil, Gutemberg H. & 172339 \\
\hline 195 & Brasil. Instituto de Pesquisa Econômica Aplicada (Ipea) & 856851 \\
\hline 196 & Brasileiro, Iara Lúcia Gomes & 207627 \\
\hline 197 & Brito, Adriana Fernandes de & 964358 \\
\hline 198 & Brito, Alessandra Scalioni & 422349 \\
\hline 199 & Brito, Leandro N. & 293427 \\
\hline 200 & Britto, José Maurício de Mello & 420944 \\
\hline 201 & Britto, Marcelo & 579171 \\
\hline 202 & Britto, Paulo Augusto P. de & 413888 \\
\hline 203 & Britto, Tatiana & 116413 \\
\hline 204 & Brugué, Quim & 619190 \\
\hline 205 & Bruno, Miguel & 239355 \\
\hline 206 & Brustlein, Vilette & 988462 \\
\hline 207 & Buarque, Sérgio C. & 183539 \\
\hline 208 & Bueno, Natália S. & 181199 \\
\hline 209 & Bugarin, Maurício & 527418 \\
\hline 210 & Bugarin, Mirta N. S. & 487293 \\
\hline
\end{tabular}




\begin{tabular}{|c|c|c|}
\hline 211 & Burnquist, Heloisa Lee & 704026 \\
\hline 212 & Buslik, Sérgio Alencar & 906999 \\
\hline 213 & Caballero, Barbara & 606261 \\
\hline 214 & Cabello, Andrea Felippe & 971877 \\
\hline 215 & Caetano, Marcelo Abi-Ramia & 967301 \\
\hline 216 & Caetano, Sidney Martins & 514576 \\
\hline 217 & Cajueiro, Daniel Oliveira & 373711 \\
\hline 218 & Calazans, Fernando Ferreira & 160427 \\
\hline 219 & Calmon, Katya Maria Nasiaseni & 935492 \\
\hline 220 & Camacho, Fernando & 291479 \\
\hline 221 & Câmara, Marcus José Reis & 813373 \\
\hline 222 & Camarano, Ana Amélia & 972396 \\
\hline 223 & Camargo, José Márcio & 173034 \\
\hline 224 & Camillo, Ronaldo & 937469 \\
\hline 225 & Campolina, Bernardo & 175598 \\
\hline 226 & Campos Neto, Carlos & 670853 \\
\hline 227 & Campos, André Gambier & 771648 \\
\hline 228 & Cândido Júnior, José Oswaldo & 943547 \\
\hline 229 & Canuto, Otaviano & 482414 \\
\hline 230 & Cardos, Simone de Souza & 112468 \\
\hline 231 & Cardoso Jr., José Celso & 946122 \\
\hline 232 & Cardoso, Antonio Semeraro Rito & 345846 \\
\hline 233 & Cardoso, Eliana A. & 231748 \\
\hline 234 & Cardoso, Gabriela Ribeiro & 804854 \\
\hline 235 & Cardoso, João Antônio P. & 868135 \\
\hline 236 & Cardoso, Larry C. & 784011 \\
\hline 237 & Cardoso, Simone de Souza & 317790 \\
\hline 238 & Carleial, Liana & 553613 \\
\hline 239 & Carlucci, Fabio Nogueira & 295009 \\
\hline 240 & Carmo, Marco Aurélio Zancanela do & 247032 \\
\hline 241 & Carneiro Netto, Dionísio Dias & 549043 \\
\hline 242 & Carneiro, Flavio Lyrio & 966918 \\
\hline 243 & Carneiro, Francisco Galrão & 986849 \\
\hline 244 & Carneiro, Isabella Gomes & 682283 \\
\hline 245 & Carneiro, Pedro & 976665 \\
\hline 246 & Carneiro, Ricardo & 351254 \\
\hline 247 & Carpena, Luciane & 936511 \\
\hline 248 & Carvalhal, André & 882545 \\
\hline 249 & Carvalho Jr., Pedro Humberto Bruno de & 762280 \\
\hline 250 & Carvalho, Alexandre Xavier Ywata de & 720340 \\
\hline 251 & Carvalho, Ana Paula & 149860 \\
\hline 252 & Carvalho, Angelita Alves de & 723107 \\
\hline 253 & Carvalho, Bruno Eustáquio Ferreira C. de & 790655 \\
\hline
\end{tabular}




\begin{tabular}{|c|c|c|}
\hline 254 & Carvalho, Carlos Eduardo & 690817 \\
\hline 255 & Carvalho, Carlos Henrique Ribeiro de & 878641 \\
\hline 256 & Carvalho, Déa & 609812 \\
\hline 257 & Carvalho, Fabiana Gomes de & 393833 \\
\hline 258 & Carvalho, Fernando J. Cardim de & 368329 \\
\hline 259 & Carvalho, João Carlos de Souza & 572955 \\
\hline 260 & Carvalho, José Alberto Magno de & 141716 \\
\hline 261 & Carvalho, José Carlos Jacob de & 788948 \\
\hline 262 & Carvalho, José Henrique Dias de & 314489 \\
\hline 263 & Carvalho, Kátia & 555177 \\
\hline 264 & Carvalho, Leonardo & 320941 \\
\hline 265 & Carvalho, Luiza & 711730 \\
\hline 266 & Carvalho, Marco Antonio de Sousa & 576653 \\
\hline 267 & Carvalho, Marina Amaral Egydio de & 831142 \\
\hline 268 & Carvalho, Mirela de & 899139 \\
\hline 269 & Carvalho, Paulo Gonzaga M. de & 629656 \\
\hline 270 & Carvalho, Ruy de Quadros & 968032 \\
\hline 271 & Carvalho, Sandro Sacchet de & 506907 \\
\hline 272 & Carvalho, Sergio Medeiros Paulino de & 746876 \\
\hline 273 & Cassiolato, José Eduardo & 188223 \\
\hline 274 & Cassiolato, Maria Martha & 858051 \\
\hline 275 & Castelan, Daniel Ricardo & 844171 \\
\hline 276 & Castelar, Armando & 987234 \\
\hline 277 & Castellana, Fabian & 335764 \\
\hline 278 & Castello Branco, Maria Luisa G. & 917661 \\
\hline 279 & Castello Branco, Tatiana Coimbra & 863934 \\
\hline 280 & Castelo Branco, Flávio; & 108955 \\
\hline 281 & Castilho, Marta dos Reis & 255976 \\
\hline 282 & Castro, Alexandre Samy de & 242135 \\
\hline 283 & Castro, Ana Célia & 597014 \\
\hline 284 & Castro, Bruno Ribeiro de & 543037 \\
\hline 285 & Castro, César Nunes de & 638342 \\
\hline 286 & Castro, Demian & 813190 \\
\hline 287 & Castro, Diego Afonso de & 964846 \\
\hline 288 & Castro, Jorge Abrahão de & 597734 \\
\hline 289 & Castro, Luiza & 507311 \\
\hline 290 & Castro, Newton Rabello de & 411859 \\
\hline 291 & Castro, Paulo Furtado de & 880316 \\
\hline 292 & Cavalcante, Eric Jardim & 438216 \\
\hline 293 & Cavalcante, Luiz Ricardo & 699035 \\
\hline 294 & Cavalcante, Pedro & 282445 \\
\hline 295 & Cavalcanti, Marco Antônio F. H. & 946030 \\
\hline 296 & Cavalini, Luciana Tricai & 227503 \\
\hline
\end{tabular}




\begin{tabular}{|c|c|c|}
\hline 297 & Ceratti, Rubem & 725331 \\
\hline 298 & Cerqueira Junior, Mário José Barbosa & 145709 \\
\hline 299 & Cerqueira, Daniel & 842392 \\
\hline 300 & Cerqueira, Vinícius dos Santos & 750189 \\
\hline 301 & Céspedes, Brisne J. V. & 129565 \\
\hline 302 & Chagas, Ana Maria de Resende & 555519 \\
\hline 303 & Chamon, Marcos & 606954 \\
\hline 304 & Chauvet, Marcelle & 644032 \\
\hline 305 & Chaves, José Valente & 735294 \\
\hline 306 & Chermont, Larissa Steiner & 677832 \\
\hline 307 & Chernavsky, Emilio & 283257 \\
\hline 308 & Chmielewska, Danuta & 945083 \\
\hline 309 & Chomitz, Kenneth M. & 315243 \\
\hline 310 & Cieplinski, André Gaspar & 900202 \\
\hline 311 & Cintra, Marcos Antonio Macedo & 156099 \\
\hline 312 & Clements, Benedict J. & 895768 \\
\hline 313 & Codes, Ana Luiza Machado de & 756846 \\
\hline 314 & Coelho Filho, Osmar & 145461 \\
\hline 315 & Coelho, Allexandro Mori & 849022 \\
\hline 316 & Coelho, Danilo & 695567 \\
\hline 317 & Coelho, Margarida Hatem Pinto & 144027 \\
\hline 318 & Cohn, Amélia & 610202 \\
\hline 319 & Conceição, Júnia Cristina & 667182 \\
\hline 320 & Conceição, Pedro Henrique Zuchi da & 291169 \\
\hline 321 & Considera, Cláudio Monteiro & 756857 \\
\hline 322 & Constantino, Michel & 597429 \\
\hline 323 & Contador, Cláudio R. & 924867 \\
\hline 324 & Corbucci, Paulo Roberto & 280883 \\
\hline 325 & Corder, Solange & 693454 \\
\hline 326 & Corrêa, Angela Maria Cassavia Jorge & 798915 \\
\hline 327 & Corrêa, Ludmila Macedo & 858656 \\
\hline 328 & Corseuil, Carlos Henrique & 934480 \\
\hline 329 & Coslovsky, Salo Vinocur & 455385 \\
\hline 330 & Costa, Alcides Jorge & 949753 \\
\hline 331 & Costa, Alysson & 207776 \\
\hline 332 & Costa, Carlos Eduardo Lampert & 520056 \\
\hline 333 & Costa, Cinthia Cabral da & 102305 \\
\hline 334 & Costa, Daniela Ribeiro da & 475610 \\
\hline 335 & Costa, Fernanda Reginatto & 306956 \\
\hline 336 & Costa, Fernando Nogueira da & 623430 \\
\hline 337 & Costa, Francisco de Assis & 391560 \\
\hline 338 & Costa, Gustavo & 106525 \\
\hline 339 & Costa, Joana Simões & 860164 \\
\hline
\end{tabular}




\begin{tabular}{|c|c|c|}
\hline 340 & Costa, Katarina Pereira da & 902912 \\
\hline 341 & Costa, Manoel Augusto & 905709 \\
\hline 342 & Costa, Nilson do Rosário & 463447 \\
\hline 343 & Costa, Veruska da Silva & 340400 \\
\hline 344 & Costa-Filho, Alfredo & 706582 \\
\hline 345 & Costanzi, Rogério Nagamine & 892283 \\
\hline 346 & Coutinho, Diogo R. & 895595 \\
\hline 347 & Coutinho, Paulo César & 762536 \\
\hline 348 & Couto, Lilia Caiado & 612673 \\
\hline 349 & Couto, Patrícia Brandão & 544615 \\
\hline 350 & Cravo, Tulio Antônio & 431085 \\
\hline 351 & Crespo, Anna & 123188 \\
\hline 352 & Cruxên, Isadora Araujo & 461860 \\
\hline 353 & Cruz Júnior, Samuel César da & 254753 \\
\hline 354 & Cruz, Bruno de Oliveira & 301347 \\
\hline 355 & Cruz, Luiz Eduardo Miranda & 211675 \\
\hline 356 & Cruz, Marcio José Vargas da & 510229 \\
\hline 357 & Cruz, Sebastião C. Velasco e & 273349 \\
\hline 358 & Cruz, Tânia Mara Eller da & 117911 \\
\hline 359 & Cuiabano, Simone Maciel & 735783 \\
\hline 360 & Cunha, Alexandre dos Santos & 510111 \\
\hline 361 & Cunha, Eleonora Schettini M. & 578198 \\
\hline 362 & Cunha, George Henrique & 282124 \\
\hline 363 & Cunha, José Marcos Pinto da & 899045 \\
\hline 364 & Cunha, Lucas & 689569 \\
\hline 365 & Cunha, Paulo Vieira da & 815287 \\
\hline 366 & Cunha, Samantha & 391807 \\
\hline 367 & Cury, Samir & 347804 \\
\hline 368 & Curzel, Rosana & 720845 \\
\hline 369 & Damasceno, Alexandre & 243771 \\
\hline 370 & David, Antonio Carlos de Albuquerque & 688349 \\
\hline 371 & David, Maria Beatriz & 365708 \\
\hline 372 & David, Pedro A. M-S. & 202261 \\
\hline 373 & De Conti, Bruno & 778814 \\
\hline 374 & De Negri, Fernanda & 886230 \\
\hline 375 & De Negri, João Alberto & 526397 \\
\hline 376 & Deboni, Fabio & 685116 \\
\hline 377 & Dedecca, Claudio Salvadori & 170461 \\
\hline 378 & Deichmann, Uwe & 964148 \\
\hline 379 & Del Grossi, Mauro Eduardo & 552764 \\
\hline 380 & Delden, Hedwig Van & 671261 \\
\hline 381 & Delgado, Guilherme Costa & 890044 \\
\hline 382 & Delgado, Ignacio Godinho & 150094 \\
\hline
\end{tabular}




\begin{tabular}{|c|c|c|}
\hline 383 & Demo, Pedro & 496283 \\
\hline 384 & Desiderá Neto, Walter Antonio & 372571 \\
\hline 385 & Devlin, Robert & 995953 \\
\hline 386 & Dezoit, Ana Lúcia & 884139 \\
\hline 387 & Di Benedetto, Roberto & 637872 \\
\hline 388 & Di Sabbato, Alberto & 688185 \\
\hline 389 & Dias, Guilherme A. V. & 933654 \\
\hline 390 & Dias, Guilherme Gomes & 410898 \\
\hline 391 & Dias, Marco Antônio Guimarães & 830752 \\
\hline 392 & Dias, Rodrigo & 397922 \\
\hline 393 & Dias, Ronaldo & 268506 \\
\hline 394 & Diawara, Hawa & 735452 \\
\hline 395 & Diaz, Maria del Carmen Vera & 224591 \\
\hline 396 & Diniz, Clélio Campolina & 249747 \\
\hline 397 & Diniz, Debora & 933129 \\
\hline 398 & Divino, José Ângelo & 376251 \\
\hline 399 & Domingues, Edson Paulo & 730581 \\
\hline 400 & Domingues, Gabriela Bertol & 964758 \\
\hline 401 & Donovan, Michael & 578999 \\
\hline 402 & Dornbusch, Rudiger & 490507 \\
\hline 403 & Dourado, Rodrigo & 515892 \\
\hline 404 & Dowall, David E. & 291858 \\
\hline 405 & Doyle, Hélyo & 511167 \\
\hline 406 & Duarte, Angelo J. M. & 881065 \\
\hline 407 & Duarte, Bruno & 297500 \\
\hline 408 & Duarte, Érico Esteves & 373460 \\
\hline 409 & Duarte, Janete & 506371 \\
\hline 410 & Duarte, Renata Pacheco Nogueira & 213498 \\
\hline 411 & Dweck, Ruth Helena & 439819 \\
\hline 412 & Eberhardt, Isaque Daniel & 641234 \\
\hline 413 & Ehlers, Ricardo Sandes & 253796 \\
\hline 414 & Ehrl, Philipp & 870535 \\
\hline 415 & Ellery Junior, Roberto de Goes & 703946 \\
\hline 416 & El-Moor, Patrícia Dario & 533109 \\
\hline 417 & Emílio, L. A. Bittencourt & 232826 \\
\hline 418 & Erber, Fabio Stefano & 818116 \\
\hline 419 & Eris, Cláudia Cunha Campos & 399042 \\
\hline 420 & Espinal, Mercedes Magdalena Lizardo & 741903 \\
\hline 421 & Esteves, Fernando Henrique de Araújo & 495840 \\
\hline 422 & Esteves, Luiz Alberto & 427755 \\
\hline 423 & Façanha, Luís Otávio & 897731 \\
\hline 424 & Fandinho, Mariana & 503428 \\
\hline 425 & Fantoni, Margarida Maria Souto & 475422 \\
\hline
\end{tabular}




\begin{tabular}{|c|c|c|}
\hline 426 & Farhi, Maryse & 695720 \\
\hline 427 & Faria, Cláudia Feres & 420479 \\
\hline 428 & Faria, João Adelino de & 590710 \\
\hline 429 & Farina, Elizabeth M. M. Q. & 413843 \\
\hline 430 & Faro, Clóvis de & 956406 \\
\hline 431 & Fausto, José Ricardo Brun & 739608 \\
\hline 432 & Féres, José & 438227 \\
\hline 433 & Fernandes, Anna Paola & 654527 \\
\hline 434 & Fernandes, Daniele & 468108 \\
\hline 435 & Fernandes, Marcelo & 724605 \\
\hline 436 & Fernandes, Maria Alice da Cunha & 986373 \\
\hline 437 & Ferrari, Rodrigo & 196699 \\
\hline 438 & Ferraz, Cláudio & 413809 \\
\hline 439 & Ferraz, Galeno & 105210 \\
\hline 440 & Ferraz, Lucas Pedreira do Couto & 792473 \\
\hline 441 & Ferreira Filho, Joaquim Bento de Souza & 375340 \\
\hline 442 & Ferreira, Adriana Nunes & 133828 \\
\hline 443 & Ferreira, Alberto & 484485 \\
\hline 444 & Ferreira, Alessandra dos Santos & 614896 \\
\hline 445 & Ferreira, Ennio & 621615 \\
\hline 446 & Ferreira, Helder & 424027 \\
\hline 447 & Ferreira, Iansã Melo & 553074 \\
\hline 448 & Ferreira, Léo da Rocha & 379457 \\
\hline 449 & Ferreira, Marco A. R. & 116674 \\
\hline 450 & Ferreira, Mônica Guerra & 328310 \\
\hline 451 & Ferreira, Pedro Cavalcanti & 486127 \\
\hline 452 & Ferreira, Rosane Maria Pimentel Magalhães & 436164 \\
\hline 453 & Ferreira, Sergio Guimarães & 271640 \\
\hline 454 & Ferreira, Valéria & 102965 \\
\hline 455 & Fiani, Ronaldo & 327811 \\
\hline 456 & Figueiredo, Adriano M. R. & 832450 \\
\hline 457 & Figueiredo, José Carlos & 384305 \\
\hline 458 & Figueiredo, Lízia de & 309561 \\
\hline 459 & Figueiredo, Marina Morenna Alves de & 158739 \\
\hline 460 & Figueiredo, Nelly Maria Sansígolo de & 421287 \\
\hline 461 & Filgueiras, Fernando & 952946 \\
\hline 462 & Filgueiras, Heloiza Valverde & 561738 \\
\hline 463 & Filgueiras, Marina & 212868 \\
\hline 464 & Fioravante, Dea Guerra & 282529 \\
\hline 465 & Fiorêncio, Antonio & 574991 \\
\hline 466 & Fiori, José Luís & 424490 \\
\hline 467 & Firpo, Sergio & 476919 \\
\hline 468 & Fiuza, Eduardo P. S. & 403577 \\
\hline
\end{tabular}




\begin{tabular}{|c|c|c|}
\hline 469 & Fiuza, Gabriel & 510736 \\
\hline 470 & Fleury, Afonso & 757745 \\
\hline 471 & Florêncio, Sergio Abreu e Lima & 212435 \\
\hline 472 & Fochezatto, Adelar & 803176 \\
\hline 473 & Foguel, Miguel N. & 841791 \\
\hline 474 & Fonseca, Fernanda & 429494 \\
\hline 475 & Fonseca, Francisco & 655274 \\
\hline 476 & Fonseca, Igor Ferraz da & 784025 \\
\hline 477 & Fonseca, Pedro Cezar Dutra & 364664 \\
\hline 478 & Fonseca, Renato & 188131 \\
\hline 479 & Fonseca, Thaís C. & 566812 \\
\hline 480 & Fontes, Patrícia Vivas da Silva & 240877 \\
\hline 481 & Fontoura, Natália de Oliveira & 987058 \\
\hline 482 & Forero Gonzalez, Manuel José & 274436 \\
\hline 483 & Fornazier, Armando & 361322 \\
\hline 484 & Fox, Louise & 507257 \\
\hline 485 & França, Karla & 553602 \\
\hline 486 & Franco, Luiz Gustavo Aversa & 284074 \\
\hline 487 & Franco, Samuel & 210212 \\
\hline 488 & Franklin, Ana Paula & 741482 \\
\hline 489 & Fraquelli, Carlos Antônio & 802041 \\
\hline 490 & Freitas Filho, Roberto & 173591 \\
\hline 491 & Freitas, Fabio & 637288 \\
\hline 492 & Freitas, Fernando & 343384 \\
\hline 493 & Freitas, Lúcia Rolim Santana de & 840393 \\
\hline 494 & Freitas, Maria Cristina Penido de & 727480 \\
\hline 495 & Freitas, Paulo Springer de & 140563 \\
\hline 496 & Freitas, Rogério Edivaldo & 490550 \\
\hline 497 & Frenkel, Jacob & 696589 \\
\hline 498 & Frischtak, Cláudio Roberto & 953576 \\
\hline 499 & Furniel, Ana Cristina da Matta & 379059 \\
\hline 500 & Furtado, André & 939223 \\
\hline 501 & Furtado, Bernardo Alves & 586544 \\
\hline 502 & Furtado, Paulo & 198606 \\
\hline 503 & Gaitán, Flavio & 130089 \\
\hline 504 & Galindo, Ernesto & 546997 \\
\hline 505 & Galvão, Antonio Carlos F. & 244282 \\
\hline 506 & Galvão, Cláudia Andreoli & 934065 \\
\hline 507 & Galvão, Juliana de Castro & 365112 \\
\hline 508 & Gamerman, Dani & 854889 \\
\hline 509 & Garcia, Eduardo Henrique & 925456 \\
\hline 510 & Garcia, Francisco A. Alcaraz & 307229 \\
\hline 511 & Garcia, João Luiz Kuperman & 190610 \\
\hline
\end{tabular}




\begin{tabular}{|c|c|c|}
\hline 512 & Garcia, Junior Ruiz & 891128 \\
\hline 513 & Garcia, Leila Posenato & 702761 \\
\hline 514 & Garcia, Márcio Gomes Pinto & 748836 \\
\hline 515 & Garcia, Ronaldo Coutinho & 619491 \\
\hline 516 & Garrefa, Fernando & 459781 \\
\hline 517 & Gasparini, Carlos Eduardo & 114889 \\
\hline 518 & Gasques, José Garcia & 557261 \\
\hline 519 & Gazel, Ricardo Costa & 870383 \\
\hline 520 & Gazoni, Jefferson Lorencini & 220220 \\
\hline 521 & Gentil, Denise Lobato & 129489 \\
\hline 522 & Gerardo, José Carlos & 456499 \\
\hline 523 & Ghaouri, Solange Kanso El & 495566 \\
\hline 524 & Giambiagi, Fábio & 987037 \\
\hline 525 & Giesteira, Luís Felipe & 595017 \\
\hline 526 & Giffoni, Francisco de Paula & 287533 \\
\hline 527 & Gill, Indermit & 191086 \\
\hline 528 & Gimenez, Denis Maracci & 243348 \\
\hline 529 & Gobetti, Sérgio Wulff & 174769 \\
\hline 530 & Góes, Fernanda Lira & 591547 \\
\hline 531 & Góis, José Ancelmo de & 863346 \\
\hline 532 & Gold, Philip & 577811 \\
\hline 533 & Goldani, Ana Maria & 438704 \\
\hline 534 & Gomes, Cleide de Andrade & 764068 \\
\hline 535 & Gomes, Eduardo R. & 410298 \\
\hline 536 & Gomes, Gustavo Maia & 665704 \\
\hline 537 & Gomes, João Carlos & 381198 \\
\hline 538 & Gomes, Keiti da Rocha & 117494 \\
\hline 539 & Gomes, Leonardo Augusto Vasconcelos & 746822 \\
\hline 540 & Gomes, Luiz Paulo Costa da Silva & 785930 \\
\hline 541 & Gomes, Nayara Lopes & 853486 \\
\hline 542 & Gomes, Victor & 637995 \\
\hline 543 & Gomide, Alexandre de Ávila & 261976 \\
\hline 544 & Gomide, Luiz Henrique Batistuta & 107917 \\
\hline 545 & Gonçalves, Fátima & 565446 \\
\hline 546 & Gonçalves, José Sidnei & 478338 \\
\hline 547 & Gonçalves, Reinaldo & 762919 \\
\hline 548 & Gonçalves, Robson R. & 736816 \\
\hline 549 & Gonçalves, Samo Sérgio & 965527 \\
\hline 550 & Gonzaga, Gilmar & 880325 \\
\hline 551 & Gonzaga, Gustavo & 565373 \\
\hline 552 & Gonzalez, Manuel Jose Forero & 738628 \\
\hline 553 & Gonzalez, Roberto & 345776 \\
\hline 554 & Goretkin Neto, Alexandre & 137526 \\
\hline
\end{tabular}




\begin{tabular}{|c|c|c|}
\hline 555 & Gottschalk, Martim Vicente & 600106 \\
\hline 556 & Gottshalk, Helena & 459972 \\
\hline 557 & Gouvêa, Raphael Rocha & 581109 \\
\hline 558 & Granja, Fábio Henrique & 460521 \\
\hline 559 & Greve, Júlia & 752165 \\
\hline 560 & Grimaldi, Daniel & 841685 \\
\hline 561 & Grossi, Mauro Eduardo Del & 687825 \\
\hline 562 & Guedes, Eduardo Malheiros & 950722 \\
\hline 563 & Guedes, Erivelton Pires & 865420 \\
\hline 564 & Guedes, José Rildo de Medeiros & 100930 \\
\hline 565 & Guedes, Roberta & 704283 \\
\hline 566 & Gueresi, Simone & 171257 \\
\hline 567 & Guerra, Pedro & 799595 \\
\hline 568 & Guilhoto, Joaquim José Martins & 240036 \\
\hline 569 & Guimarães, Edson P. & 709498 \\
\hline 570 & Guimarães, Eduardo Augusto & 967393 \\
\hline 571 & Guimarães, Patrícia Borba Vilar & 633891 \\
\hline 572 & Guimarães, Rafael Dantas & 460840 \\
\hline 573 & Gusmão, Paulo Pereira de & 314726 \\
\hline 574 & Gusso, Divonzir Arthur & 878349 \\
\hline 575 & Guzmán, Rolando M. & 968635 \\
\hline 576 & Haddad, Eduardo & 604124 \\
\hline 577 & Haddad, Sonia & 294073 \\
\hline 578 & Hage, Fábio Augusto Santana & 185115 \\
\hline 579 & Haguenauer, Lia & 498214 \\
\hline 580 & Hahn, Leda & 286833 \\
\hline 581 & Hallack, Michelle Carvalho Metanias & 244493 \\
\hline 582 & Hamann, Eduarda Passarelli & 327926 \\
\hline 583 & Hamasaki, Cláudia Satie & 781241 \\
\hline 584 & Harvey, A. C. & 893954 \\
\hline 585 & Hasenclever, Lia & 406609 \\
\hline 586 & Hauser, Philipp & 768269 \\
\hline 587 & Hay, Donald A. & 773380 \\
\hline 588 & Hecksher, Marcos & 743230 \\
\hline 589 & Helfand, Steven M. & 534938 \\
\hline 590 & Henderson, J. Vernon & 419624 \\
\hline 591 & Henriques, Maria Helena F. T. & 726588 \\
\hline 592 & Henriques, Ricardo & 188677 \\
\hline 593 & Hermann, Jennifer & 644889 \\
\hline 594 & Hernandez, Beatriz Muriel & 543683 \\
\hline 595 & Herrero, Verónica & 269059 \\
\hline 596 & Herrlein Júnior, Ronaldo & 207735 \\
\hline 597 & Hickmann, Ernani & 732623 \\
\hline
\end{tabular}




\begin{tabular}{|c|c|c|}
\hline 598 & Hillebrand, Giovanni & 268051 \\
\hline 599 & Hirata, Helena Sumiko & 695729 \\
\hline 600 & Hiratuka, Célio & 382512 \\
\hline 601 & Hiroi, Taeko & 375138 \\
\hline 602 & Hirst, Monica & 589197 \\
\hline 603 & Hoffmann, Rodolfo & 245783 \\
\hline 604 & Holanda, Antônio Nilson Craveiro & 656143 \\
\hline 605 & Holanda, Frederico Rosa Borges de & 699547 \\
\hline 606 & Hollauer, Gilberto & 310500 \\
\hline 607 & Holzhacker, Denilde & 724393 \\
\hline 608 & Homsy, Guilherme Vampré & 649410 \\
\hline 609 & Horta, Maria Helena & 119871 \\
\hline 610 & Huber, Richard & 750768 \\
\hline 611 & Humphrey, John & 569931 \\
\hline 612 & Hurtienne, Thomas & 145551 \\
\hline 613 & Ibarra, Antonio & 111675 \\
\hline 614 & Igliori, Danilo Camargo & 113853 \\
\hline 615 & Ikeda, Marcelo & 815447 \\
\hline 616 & Ismael, Ricardo & 961074 \\
\hline 617 & Issler, João Victor & 192416 \\
\hline 618 & Izaki, Rejane Sayuri & 527648 \\
\hline 619 & Jaccoud, Luciana & 786357 \\
\hline 620 & Jaguaribe, Anna & 199071 \\
\hline 621 & Jakob, André Codo & 370942 \\
\hline 622 & Jatobá, Jorge & 431669 \\
\hline 623 & Jatobá, Sérgio & 208642 \\
\hline 624 & Jeronymo, Renata & 845944 \\
\hline 625 & Jesus Filho, Jaime de & 482371 \\
\hline 626 & Jorge, Angela & 379844 \\
\hline 627 & Jorge, Caroline Teixeira & 812231 \\
\hline 628 & Jorge, Marina Filgueiras & 655009 \\
\hline 629 & Kacef, Osvaldo & 644623 \\
\hline 630 & Kannebley Júnior, Sérgio & 228317 \\
\hline 631 & Kanso, Solange & 125659 \\
\hline 632 & Kasper, Albrecht & 296755 \\
\hline 633 & Kaufmann, Carla Xavier dos Santos & 853465 \\
\hline 634 & Kenkel, Kai Michael & 835732 \\
\hline 635 & Kipnis, Bernardo & 271575 \\
\hline 636 & Kirschner, Tereza Cristina & 927815 \\
\hline 637 & Koeller, Priscila & 671089 \\
\hline 638 & Kornis, George E. M. & 151984 \\
\hline 639 & Kozak, Jorge Conrado & 364655 \\
\hline 640 & Krause, Cleandro & 696627 \\
\hline
\end{tabular}




\begin{tabular}{|c|c|c|}
\hline 641 & Kubota, Luis Claudio & 649954 \\
\hline 642 & Kume, Honorio & 770131 \\
\hline 643 & Lafetá, Danniel & 376900 \\
\hline 644 & Lall, Somik V. & 112538 \\
\hline 645 & Lam, David & 405531 \\
\hline 646 & Lameirão, Camila Romero & 345127 \\
\hline 647 & Lamy, Philippe & 116298 \\
\hline 648 & Landim, Leilah & 257297 \\
\hline 649 & Lanzara, Arnaldo Provasi & 858589 \\
\hline 650 & Lanzaro, Jorge & 204043 \\
\hline 651 & Laplane, Mariano & 875506 \\
\hline 652 & Lassance, Antonio & 460853 \\
\hline 653 & Lastres, Helena Maria Martins & 544059 \\
\hline 654 & Laureto, Camilo Rey & 626042 \\
\hline 655 & Lavalle, Adrian Gurza & 774538 \\
\hline 656 & Lavalle, Jorge Leiva & 544554 \\
\hline 657 & Lavinas, Lena & 374265 \\
\hline 658 & Lazo, Aída C. G. Verdugo & 251098 \\
\hline 659 & Leal, Ésio Moreira & 995636 \\
\hline 660 & Leal, João Carvalho & 535505 \\
\hline 661 & Leal, João Paulo G. & 188599 \\
\hline 662 & Leal, Ricardo P. Câmara & 372860 \\
\hline 663 & Leal, Rodrigo Lima Verde & 319080 \\
\hline 664 & Leão, Isabela D'loan Silva & 267116 \\
\hline 665 & Leão, Rodrigo Pimentel Ferreira & 630341 \\
\hline 666 & Leite, Cristiane Kerches da Silva & 261936 \\
\hline 667 & Leite, Marcos Vinicius Chiliatto & 258623 \\
\hline 668 & Leite, Phillippe G. & 165155 \\
\hline 669 & Leite, Sabina Kauark & 594283 \\
\hline 670 & Leme, Fernanda Paes & 874167 \\
\hline 671 & Lerda, Sandra & 801827 \\
\hline 672 & Levy, Paulo Mansur & 258152 \\
\hline 673 & Lima Neto, Fernando & 381382 \\
\hline 674 & Lima Neto, Vicente Correia & 930913 \\
\hline 675 & Lima, Adriana Fernandes & 867154 \\
\hline 676 & Lima, Edilberto Carlos Pontes & 841624 \\
\hline 677 & Lima, Elcyon Caiado Rocha & 605962 \\
\hline 678 & Lima, Gilberto Tadeu & 659353 \\
\hline 679 & Lima, Iêda Maria de Oliveira & 936101 \\
\hline 680 & Lima, Lucikelly dos Santos & 368579 \\
\hline 681 & Lima, Marcus Vinícius Magalhães de & 588580 \\
\hline 682 & Lima, Paula Pompeu Fiuza & 260039 \\
\hline 683 & Lima, Renato Sérgio de & 765759 \\
\hline
\end{tabular}




\begin{tabular}{|c|c|c|}
\hline 684 & Lima, Ricardo R. A. & 655569 \\
\hline 685 & Lima, Uallace Moreira & 206382 \\
\hline 686 & Limp, Rodrigo & 276955 \\
\hline 687 & Linke, Clarisse & 373790 \\
\hline 688 & Lino, Luiz Alberto & 562669 \\
\hline 689 & Lins, Isabella L. & 336496 \\
\hline 690 & Lins, Leonardo Melo & 753728 \\
\hline 691 & Lisboa, Marcos de B. & 454931 \\
\hline 692 & Lledó, Victor Duarte & 849414 \\
\hline 693 & Lobão, Evelyn R. & 480635 \\
\hline 694 & Lobão, Waldir & 690274 \\
\hline 695 & Lobo, Thereza & 976110 \\
\hline 696 & Longo, Rose Mary Juliano & 744353 \\
\hline 697 & Lopes, Francisco & 172661 \\
\hline 698 & Lopes, Geovane de Oliveira & 733113 \\
\hline 699 & Lopes, Hedibert Freitas & 379562 \\
\hline 700 & Lopes, Juarez Rubens Brandão & 600058 \\
\hline 701 & Lopes, Márcio Duarte & 663543 \\
\hline 702 & Lopez Júnior, Felix Garcia & 392513 \\
\hline 703 & López-Monti, Rafael M. & 424769 \\
\hline 704 & Lopreato, Francisco Luiz C. & 420179 \\
\hline 705 & Loural, Claudio de Almeida & 441139 \\
\hline 706 & Loureiro, Erica de Castro & 330540 \\
\hline 707 & Loureiro, Maria Rita & 393519 \\
\hline 708 & Loureiro, Paulo R. A. & 614790 \\
\hline 709 & Lourete, Acácio Alvarenga & 114453 \\
\hline 710 & Lucini, Juana Andrade de & 869302 \\
\hline 711 & Lück, Heloísa & 657142 \\
\hline 712 & Luedemann, Gustavo & 866110 \\
\hline 713 & Lui, Roberto & 312015 \\
\hline 714 & Luporini, Viviane & 631238 \\
\hline 715 & Lustosa, Bernardo Junqueira & 519233 \\
\hline 716 & Lustosa, Paulo Roberto Barbosa & 602237 \\
\hline 717 & Luz, Everaldo Manoel & 850960 \\
\hline 718 & Lyra, Diego Mendes & 477226 \\
\hline 719 & Lyra, Flávio Tavares de & 911642 \\
\hline 720 & Mac Dowell, Maria Cristina & 863644 \\
\hline 721 & Macário, Vinicius & 884625 \\
\hline 722 & Macchi, Cibele Andrade & 460847 \\
\hline 723 & Macedo, Debora Maria Borges de & 660577 \\
\hline 724 & Macedo, Guilherme Matoso & 575727 \\
\hline 725 & Macedo, Hildebrando Rodrigues & 351514 \\
\hline 726 & Macedo, Joseli & 329285 \\
\hline
\end{tabular}




\begin{tabular}{|c|c|c|}
\hline 727 & Macedo, Paulo Brígido Rocha & 175898 \\
\hline 728 & Machado, Ana Flávia & 236551 \\
\hline 729 & Machado, Danielle Carusi & 842469 \\
\hline 730 & Machado, João Bosco Mesquita & 328930 \\
\hline 731 & Machado, Laura & 486513 \\
\hline 732 & Maciel, Cláudio S. & 459600 \\
\hline 733 & Maciel, Evandro & 351854 \\
\hline 734 & Maciente, Aguinaldo Nogueira & 421131 \\
\hline 735 & Magalhães, João Carlos Ramos & 443261 \\
\hline 736 & Magalhães, Kepler & 684554 \\
\hline 737 & Magalhães, Luís Carlos Garcia de & 764925 \\
\hline 738 & Magalhães, Luís Carlos Garcia de & 196360 \\
\hline 739 & Magalhães, Ricardo & 438296 \\
\hline 740 & Magina, Manoel Augusto & 909273 \\
\hline 741 & Maka, Alexis & 404403 \\
\hline 742 & Malan, Pedro Sampaio & 469115 \\
\hline 743 & Maldonado, Wilfredo Leiva & 398798 \\
\hline 744 & Mallmann, Marthin Leo & 532261 \\
\hline 745 & Manão, Daniele & 948609 \\
\hline 746 & Manhiça, Félix Antônio & 228738 \\
\hline 747 & Maniero, Leandro Vicente Fernandes & 158658 \\
\hline 748 & Marçal, Emerson Fernandes & 806578 \\
\hline 749 & Marconi, Nelson & 450545 \\
\hline 750 & Margulis, Sergio & 606897 \\
\hline 751 & Mariano, Marcelo Passini & 281545 \\
\hline 752 & Marinho, Alexandre & 192945 \\
\hline 753 & Marinho, Bruno Arruda & 119196 \\
\hline 754 & Marinho, Nyedja da Silva & 459319 \\
\hline 755 & Markwald, Ricardo & 520744 \\
\hline 756 & Marques, Antonio Emílio S. & 103781 \\
\hline 757 & Marques, Hamilton Nonato & 141844 \\
\hline 758 & Marques, Mariano Cesar & 952177 \\
\hline 759 & Marques, Newton & 756191 \\
\hline 760 & Marques, Paulo Marcello Fonseca & 198916 \\
\hline 761 & Marques, Roberta Wanderley da Costa & 878753 \\
\hline 762 & Marques, Sérgio de Azevedo & 318450 \\
\hline 763 & Marques-Pereira, Jaime & 219879 \\
\hline 764 & Marra, Fátima & 879460 \\
\hline 765 & Martine, George & 249523 \\
\hline 766 & Martinez, Thiago Sevilhano & 290855 \\
\hline 767 & Martins, Ana Paula Antunes & 564120 \\
\hline 768 & Martins, Raquel de Fátima & 474005 \\
\hline 769 & Martins, Thiago Guerrera & 440316 \\
\hline
\end{tabular}




\begin{tabular}{|c|c|c|}
\hline 770 & Martins, Wagner de Jesus & 785998 \\
\hline 771 & Mascolo, João Luiz & 375681 \\
\hline 772 & Massena, Rosa M. R. & 671044 \\
\hline 773 & Mata, Daniel da & 538966 \\
\hline 774 & Mata, Milton da & 776561 \\
\hline 775 & Matesco, Virene & 368412 \\
\hline 776 & Mathias, Alexandre & 439870 \\
\hline 777 & Matijascic, Milko & 788978 \\
\hline 778 & Mation, Lucas Ferreira & 815132 \\
\hline 779 & Matos Filho, José Coelho & 629693 \\
\hline 780 & Matos, Mariana Vieira Martins & 920914 \\
\hline 781 & Matsumura, Marco S. & 350989 \\
\hline 782 & Mattos, Fernando Augusto Mansor de & 726008 \\
\hline 783 & Mattos, Roberto Sant'Anna & 484872 \\
\hline 784 & May, Peter Herman & 553089 \\
\hline 785 & McGreevey, William & 103308 \\
\hline 786 & Medeiros, Bernardo Abreu de & 468659 \\
\hline 787 & Medeiros, Cézar Manoel de & 928086 \\
\hline 788 & Medeiros, Marcelo & 714134 \\
\hline 789 & Medeiros, Valério Augusto Soares de & 370102 \\
\hline 790 & Medici, André Cezar & 577095 \\
\hline 791 & Medina, Mérida & 570846 \\
\hline 792 & Medrano, Luis Alberto & 169642 \\
\hline 793 & Meirelles, Maira Beckman & 155057 \\
\hline 794 & Meirelles, Raquel de Lima & 554628 \\
\hline 795 & Mello, Bernardo Assunção & 640265 \\
\hline 796 & Mello, Flávia de Campos & 582152 \\
\hline 797 & Mello, Gisela Vaz de & 426038 \\
\hline 798 & Mello, João Manoel Pinho de & 614875 \\
\hline 799 & Mello, Juliana Leitão e & 786627 \\
\hline 800 & Mello, Juliana Leitão e & 339073 \\
\hline 801 & Mello, Ricardo & 655768 \\
\hline 802 & Melo, Giovani Monteiro & 268096 \\
\hline 803 & Melo, Gustavo Amaral Ferreira de & 467570 \\
\hline 804 & Melo, Hildete Pereira de & 667688 \\
\hline 805 & Melo, Sâmia Rocha de Oliveira & 785667 \\
\hline 806 & Melo, Valdir & 888042 \\
\hline 807 & Mendes, Ana Paula Fernandes & 298090 \\
\hline 808 & Mendes, Constantino Cronemberger & 426824 \\
\hline 809 & Mendes, Francisco Eduardo & 415392 \\
\hline 810 & Mendes, Luiz Carlos & 162224 \\
\hline 811 & Mendonça, Helder Ferreira & 905684 \\
\hline 812 & Mendonça, João Luís & 493954 \\
\hline
\end{tabular}




\begin{tabular}{|c|c|c|}
\hline 813 & Mendonça, Marco Aurélio Alves de & 927784 \\
\hline 814 & Mendonça, Mário & 950403 \\
\hline 815 & Mendonça, Rosane & 962477 \\
\hline 816 & Meneguello, Rachel & 295640 \\
\hline 817 & Meneguin, Fernando B. & 675846 \\
\hline 818 & Menezes, Rafael Terra de & 158236 \\
\hline 819 & Menezes, Raul Miranda & 432286 \\
\hline 820 & Menezes, Ronald do Amaral & 614073 \\
\hline 821 & Menezes, Tatiane Almeida de & 754404 \\
\hline 822 & Menicucci, Telma Maria Gonçalves & 262846 \\
\hline 823 & Mesentier, Allan & 300160 \\
\hline 824 & Mesquita, Ana Cleusa Serra & 476715 \\
\hline 825 & Mesquita, Mário M. C. & 906439 \\
\hline 826 & Messa, Alexandre & 280687 \\
\hline 827 & Meyer, Tiago Rinaldi & 423465 \\
\hline 828 & Migon, Hélio S. & 559786 \\
\hline 829 & Miguez, Thiago & 465852 \\
\hline 830 & Milani, Daniela Nogueira & 109386 \\
\hline 831 & Milhomem, Ethianne Érica Lucena & 686155 \\
\hline 832 & Miranda, Geralda Luiza de & 919920 \\
\hline 833 & Miranda, José Carlos & 218832 \\
\hline 834 & Miranda, Pedro & 316462 \\
\hline 835 & Miranda, Rogério Boueri & 623856 \\
\hline 836 & Miyamoto, Shiguenoli & 612946 \\
\hline 837 & Miyata, Shiyuiti & 198012 \\
\hline 838 & Modenesi, André de Melo & 109151 \\
\hline 839 & Modenesi, Rui Lyrio & 808777 \\
\hline 840 & Moguillansky, Graciela & 865752 \\
\hline 841 & Monasterio, Leonardo & 350210 \\
\hline 842 & Monteiro Neto, Aristides & 606476 \\
\hline 843 & Monteiro, Ana Beatriz S. & 648083 \\
\hline 844 & Monteiro, Marcelo Balloti & 720142 \\
\hline 845 & Montenegro, João Lopes de Albuquerque & 805324 \\
\hline 846 & Montero, Fernando & 659257 \\
\hline 847 & Mora, Mônica & 812238 \\
\hline 848 & Moraes Neto, Manoel Batista de & 723561 \\
\hline 849 & Moraes, Rodrigo Fracalossi de & 145170 \\
\hline 850 & Moraes, Thiago & 557818 \\
\hline 851 & Moraes, Thyago Antônio de & 228598 \\
\hline 852 & Morais, José Mauro de & 493802 \\
\hline 853 & Morais, Maria da Piedade & 201056 \\
\hline 854 & Morais, Rafael Pinho Senra de & 132339 \\
\hline 855 & Morandi, Lucilene & 205302 \\
\hline
\end{tabular}




\begin{tabular}{|c|c|c|}
\hline 856 & Moreira, Ajax R. B. & 858299 \\
\hline 857 & Moreira, Heloiza Camargos & 415043 \\
\hline 858 & Moreira, Rafael Henrique Rodrigues & 231781 \\
\hline 859 & Moreira, Sérvulo Vicente & 226329 \\
\hline 860 & Moreira, Tito Belchior & 947182 \\
\hline 861 & Moreno, Arlinda Barbosa & 265396 \\
\hline 862 & Moriconi, Gabriela Miranda & 761631 \\
\hline 863 & Mostafa, Joana & 965225 \\
\hline 864 & Mota, José Aroudo & 637923 \\
\hline 865 & Motta, Diana & 796925 \\
\hline 866 & Motta, Ronaldo Seroa da & 467337 \\
\hline 867 & Moura, Adriana Maria Magalhães de & 702063 \\
\hline 868 & Moura, Rodrigo Leandro & 448201 \\
\hline 869 & Moura, Rosa & 563102 \\
\hline 870 & Moura, Tatiana Whately de & 783505 \\
\hline 871 & Muchnik, Laura & 699443 \\
\hline 872 & Mueller, Charles Curt & 997035 \\
\hline 873 & Müller, Carolina & 694790 \\
\hline 874 & Murphy, Kevin M. & 273319 \\
\hline 875 & Mussi, Carlos & 948248 \\
\hline 876 & Musumeci, Leonarda & 747210 \\
\hline 877 & Nadalin, Vanessa & 925842 \\
\hline 878 & Nagem, Fernanda Abreu & 467715 \\
\hline 879 & Naidim, Leane C. & 135051 \\
\hline 880 & Nakabashi, Luciano & 453705 \\
\hline 881 & Nascimento, Cynthia Araujo & 478780 \\
\hline 882 & Nascimento, Mabel & 953299 \\
\hline 883 & Nascimento, Paulo A. Meyer M. & 877497 \\
\hline 884 & Natalino, Marco Antonio Carvalho & 840647 \\
\hline 885 & Naticchioni, Paolo & 891680 \\
\hline 886 & Navarro, Cláudio Alexandre & 574283 \\
\hline 887 & Nazareno, Luísa & 409280 \\
\hline 888 & Nepstad, Daniel & 527376 \\
\hline 889 & Neri, Marcelo Côrtes & 742671 \\
\hline 890 & Neves, Cesar das & 488071 \\
\hline 891 & Nguyen, Diep & 543960 \\
\hline 892 & Nitsch, Manfred & 752253 \\
\hline 893 & Nóbrega, Maílson da & 477637 \\
\hline 894 & Nogueira, Mauro Oddo & 377713 \\
\hline 895 & Nogueira, Roberto Passos & 766189 \\
\hline 896 & Nonnenberg, Marcelo José Braga & 830622 \\
\hline 897 & Noronha, Eduardo Garutti & 401542 \\
\hline 898 & Novellino, Maria Salet & 939916 \\
\hline
\end{tabular}




\begin{tabular}{|c|c|c|}
\hline 899 & Nunes, André & 999139 \\
\hline 900 & Nunes, Rubens & 113469 \\
\hline 901 & O’Dell, William J. & 297879 \\
\hline 902 & Ocké-Reis, Carlos Octávio & 730987 \\
\hline 903 & Ohana, Eduardo Felipe & 923507 \\
\hline 904 & Oliveira Filho, Guilhermino & 377900 \\
\hline 905 & Oliveira Filho, Luiz Chrysóstomo de & 478824 \\
\hline 906 & Oliveira Jr., Márcio de & 272068 \\
\hline 907 & Oliveira Junior, Almir de & 226617 \\
\hline 908 & Oliveira Júnior, Márcio de & 597614 \\
\hline 909 & Oliveira Neto, José Carneiro da Cunha & 913678 \\
\hline 910 & Oliveira, Adilson de & 264984 \\
\hline 911 & Oliveira, Alexandre Batista de & 676346 \\
\hline 912 & Oliveira, Amâncio Jorge & 799683 \\
\hline 913 & Oliveira, André Rossi de & 658999 \\
\hline 914 & Oliveira, Carlos Gonçalo de & 314087 \\
\hline 915 & Oliveira, Carlos Wagner de A. & 877046 \\
\hline 916 & Oliveira, Daniel A. Ribeiro de & 993981 \\
\hline 917 & Oliveira, Fabrício Augusto de & 613838 \\
\hline 918 & Oliveira, Francisco Eduardo Barreto de & 228253 \\
\hline 919 & Oliveira, Geraldo Lopes de & 798513 \\
\hline 920 & Oliveira, Gesner & 827203 \\
\hline 921 & Oliveira, Giuliano Contento de & 812266 \\
\hline 922 & Oliveira, Henrique Altemani de & 337125 \\
\hline 923 & Oliveira, Ismael Carlos de & 733587 \\
\hline 924 & Oliveira, Ivan Tiago Machado & 977072 \\
\hline 925 & Oliveira, Jader José de & 337449 \\
\hline 926 & Oliveira, João Barbosa de & 762224 \\
\hline 927 & Oliveira, João Maria de & 806316 \\
\hline 928 & Oliveira, José Arnaldo F. G. de & 789648 \\
\hline 929 & Oliveira, José Marcos Domingues de & 163032 \\
\hline 930 & Oliveira, Liliane Lúcia Nunes de Aranha & 848795 \\
\hline 931 & Oliveira, Luciana Las Casas & 341299 \\
\hline 932 & Oliveira, Luis Felipe Batista de & 157292 \\
\hline 933 & Oliveira, Marcelo Pereira & 627788 \\
\hline 934 & Oliveira, Márcio Augusto de & 417343 \\
\hline 935 & Oliveira, Margarida Maria Sousa de & 924861 \\
\hline 936 & Oliveira, Marília Silva de & 184661 \\
\hline 937 & Oliveira, Michel Ângelo Constantino de & 179636 \\
\hline 938 & Oliveira, Raissa Menezes de & 507851 \\
\hline 939 & Oliveira, Wesley & 368852 \\
\hline 940 & Orair, Rodrigo Octávio & 393984 \\
\hline 941 & Oreiro, José Luis & 672205 \\
\hline
\end{tabular}




\begin{tabular}{|c|c|c|}
\hline 942 & Orrico Filho, Rômulo Dante & 968234 \\
\hline 943 & Ortiz, Ramon Arigoni & 746710 \\
\hline 944 & Osório, Rafael Guerreiro & 180840 \\
\hline 945 & Pacheco, Carlos Américo & 913631 \\
\hline 946 & Pacheco, Fernando Flávio & 497220 \\
\hline 947 & Padula, Raphael & 102953 \\
\hline 948 & Paez, Marina & 237351 \\
\hline 949 & Paiva, Andrea Barreto de & 272790 \\
\hline 950 & Paiva, Luis Henrique & 435626 \\
\hline 951 & Paiva, Maria de Fátima Araújo & 282432 \\
\hline 952 & Panariello, Lúcia Malnati & 116937 \\
\hline 953 & Panariello, Marcos & 229694 \\
\hline 954 & Parente Filho, José & 110830 \\
\hline 955 & Parente, Maria Andreia & 249536 \\
\hline 956 & Parente, Marta & 281259 \\
\hline 957 & Pascom, Ana Roberta Pati & 735341 \\
\hline 958 & Pasinato, Maria Tereza & 758766 \\
\hline 959 & Passos, Maria Cristina & 921245 \\
\hline 960 & Paula, Jean Marlo Pepino de & 859239 \\
\hline 961 & Paula, Luiz Fernando de & 765456 \\
\hline 962 & Paulsen, Sandra Silva & 526474 \\
\hline 963 & Payeras, José Adrian Pintos & 487183 \\
\hline 964 & Pedroso, Ana Cristina de Souza & 154677 \\
\hline 965 & Pedroso, Frederico Ferreira Fonseca & 699453 \\
\hline 966 & Pedroti, Paula Maciel & 579287 \\
\hline 967 & Pêgo Filho, Bolívar & 136286 \\
\hline 968 & Peixoto, Marcus & 421555 \\
\hline 969 & Peliano, Anna Maria Medeiros & 950483 \\
\hline 970 & Pena, Marina Garcia & 585996 \\
\hline 971 & Pereira, Ana Elisa Gonçalves & 653522 \\
\hline 972 & Pereira, Ana Karine & 686986 \\
\hline 973 & Pereira, Edgard Antônio & 656920 \\
\hline 974 & Pereira, Eduardo da Silva & 785760 \\
\hline 975 & Pereira, Francisco & 955578 \\
\hline 976 & Pereira, Juan José & 416680 \\
\hline 977 & Pereira, Lia Alt & 249484 \\
\hline 978 & Pereira, Lia Valls & 519435 \\
\hline 979 & Pereira, Newton Müller & 608048 \\
\hline 980 & Pereira, Pedro L. Valls & 113229 \\
\hline 981 & Pereira, Rafael Henrique Moraes & 572819 \\
\hline 982 & Pereira, Ricardo Mendes & 269557 \\
\hline 983 & Pereira, Rodrigo Mendes & 419447 \\
\hline 984 & Pereira, Thiago Rabelo & 515857 \\
\hline
\end{tabular}




\begin{tabular}{|c|c|c|}
\hline 985 & Pero, Valéria & 908813 \\
\hline 986 & Perobelli, Fernando S. & 673605 \\
\hline 987 & Pessoa, Elisa de Paula & 113726 \\
\hline 988 & Pessoa, Marcelo & 555629 \\
\hline 989 & Pessoa, Ruy Silva & 726315 \\
\hline 990 & Pessôa, Samuel & 289128 \\
\hline 991 & Petinelli, Viviane & 279615 \\
\hline 992 & Peyneau, Fernanda Paes Leme & 922413 \\
\hline 993 & Piancastelli, Marcelo & 855367 \\
\hline 994 & Piani, Guida & 209132 \\
\hline 995 & Pianto, Donald Matthew & 593586 \\
\hline 996 & Pimentel, Débora & 128002 \\
\hline 997 & Pimentel, Márcia & 845830 \\
\hline 998 & Pin, Cedric & 240387 \\
\hline 999 & Pinheiro, Armando Castelar & 288536 \\
\hline 1000 & Pinheiro, Bruno Rodrigues & 686544 \\
\hline 1001 & Pinheiro, Felipe & 916939 \\
\hline 1002 & Pinheiro, Luana & 877447 \\
\hline 1003 & Pinheiro, Maurício Mota Saboya & 437260 \\
\hline 1004 & Pinheiro, Sonoe Sugahara & 272213 \\
\hline 1005 & Pinheiro, Vinicius & 491662 \\
\hline 1006 & Pinkusfeld, Carlos & 222686 \\
\hline 1007 & Pino, Bruno Ayllón & 588242 \\
\hline 1008 & Piñón, Maria & 801498 \\
\hline 1009 & Pinto Junior, Jony & 675962 \\
\hline 1010 & Pinto, Alexandre & 629855 \\
\hline 1011 & Pinto, Eduardo Costa & 797057 \\
\hline 1012 & Pinto, Luiz Fernando Sanná & 362511 \\
\hline 1013 & Pinto, Márcia & 186251 \\
\hline 1014 & Pinto, Marly Santos & 696729 \\
\hline 1015 & Piola, Sérgio Francisco & 481457 \\
\hline 1016 & Piras, Stefania Schimaneski & 583029 \\
\hline 1017 & Pires, Manoel Carlos de Castro & 235857 \\
\hline 1018 & Pires, Murilo José de Souza & 340503 \\
\hline 1019 & Pires, Roberto Rocha C. & 705971 \\
\hline 1020 & Pogrebinschi, Thamy & 331821 \\
\hline 1021 & Pommeret, Aude & 653429 \\
\hline 1022 & Pompermayer, Fabiano Mezadre & 953839 \\
\hline 1023 & Porcaro, Rosa Maria & 616475 \\
\hline 1024 & Portugal, Sérgio S. & 599193 \\
\hline 1025 & Pourchet, Henry & 584574 \\
\hline 1026 & Prates, Daniela Magalhães & 376924 \\
\hline 1027 & Proni, Marcelo Weishaupt & 843320 \\
\hline
\end{tabular}




\begin{tabular}{|c|c|c|}
\hline 1028 & Punzo, Lionello & 362205 \\
\hline 1029 & Puterman, Martin L. & 852266 \\
\hline 1030 & Quandt, Carlos Olavo & 984658 \\
\hline 1031 & Queiroz, Cristina & 547100 \\
\hline 1032 & Queiroz, Glauber Pimentel de & 726373 \\
\hline 1033 & Queiroz, Iuri Vladimir & 647616 \\
\hline 1034 & Querino, Ana Carolina & 763587 \\
\hline 1035 & Quinamo, Tarcísio & 594995 \\
\hline 1036 & Quintaes, Giovani & 137573 \\
\hline 1037 & Rabelo, Flávio & 762162 \\
\hline 1038 & Rabelo, Raquel A. & 167362 \\
\hline 1039 & Rabetti, Matheus dos Santos & 812914 \\
\hline 1040 & Raimundo, Licio da Costa & 415054 \\
\hline 1041 & Ramalho, Joaquim & 851552 \\
\hline 1042 & Ramos, Carlos Alberto & 781167 \\
\hline 1043 & Ramos, Daniel & 956619 \\
\hline 1044 & Ramos, Daniela Peixoto & 864610 \\
\hline 1045 & Ramos, Lauro & 524828 \\
\hline 1046 & Ramos, Roberto Luís Olinto & 857339 \\
\hline 1047 & Ramos, Zuleide do Valle Oliveira & 860020 \\
\hline 1048 & Ramundo, Julio Cesar Maciel & 934801 \\
\hline 1049 & Rangel, Leonardo & 607687 \\
\hline 1050 & Rebelo, Jorge & 205444 \\
\hline 1051 & Rech, Alceu Roque & 107149 \\
\hline 1052 & Reiff, Luis Otávio & 184130 \\
\hline 1053 & Reis, Anna Carolina & 219371 \\
\hline 1054 & Reis, Cristina Fróes de Borja & 182752 \\
\hline 1055 & Reis, Eustáquio J. & 277323 \\
\hline 1056 & Reis, José Guilherme Almeida & 752901 \\
\hline 1057 & Reis, Maurício Cortez & 270937 \\
\hline 1058 & Rennó, Lucio & 281072 \\
\hline 1059 & Resende, André Lara & 895105 \\
\hline 1060 & Resende, Guilherme & 927278 \\
\hline 1061 & Resende, Luis Fernando de Lara & 844035 \\
\hline 1062 & Resende, Marcelo de Moura Lara & 909200 \\
\hline 1063 & Resende, Marco Flávio da Cunha & 375064 \\
\hline 1064 & Reynaud, Arnaud & 191642 \\
\hline 1065 & Rezende, Fernando & 804408 \\
\hline 1066 & Rezende, Gervásio Castro de & 579356 \\
\hline 1067 & Rezende, Raimer Rodrigues & 203401 \\
\hline 1068 & Ribas, Rafael Perez & 590939 \\
\hline 1069 & Ribeiro, Carlos Dimas Martins & 595101 \\
\hline 1070 & Ribeiro, Eduardo Pontual & 254477 \\
\hline
\end{tabular}




\begin{tabular}{|c|c|c|}
\hline 1071 & Ribeiro, Fernando José & 540115 \\
\hline 1072 & Ribeiro, José Aparecido Carlos & 938626 \\
\hline 1073 & Ribeiro, José Mendes & 151932 \\
\hline 1074 & Ribeiro, Leonardo de Lima & 709240 \\
\hline 1075 & Ribeiro, Luis Alberto de L. C. & 459631 \\
\hline 1076 & Ribeiro, Márcio Bruno & 601830 \\
\hline 1077 & Ribeiro, Marco Aurélio de Sá & 723859 \\
\hline 1078 & Ribeiro, Priscila Fernandes & 742650 \\
\hline 1079 & Ribeiro, Uriella Coelho & 271015 \\
\hline 1080 & Rios, Sandra P. & 981814 \\
\hline 1081 & Rivero, Patrícia Silveira & 284599 \\
\hline 1082 & Rocha, Antônio Jorge Ramalho da & 208753 \\
\hline 1083 & Rocha, Carlos Frederico Leão & 161059 \\
\hline 1084 & Rocha, Daniela Barros & 759682 \\
\hline 1085 & Rocha, Denise C. Correa da & 526313 \\
\hline 1086 & Rocha, Frederico & 396091 \\
\hline 1087 & Rocha, Katia & 145459 \\
\hline 1088 & Rocha, Marco Antonio Martins da & 693405 \\
\hline 1089 & Rocha, Marcos & 900134 \\
\hline 1090 & Rocha, Roberto de Rezende & 392223 \\
\hline 1091 & Rocha, Sonia & 365687 \\
\hline 1092 & Rocha, Wanderson Silva & 452987 \\
\hline 1093 & Rodrigues Júnior, Waldery & 345773 \\
\hline 1094 & Rodrigues, Alberto Alves & 420415 \\
\hline 1095 & Rodrigues, Maria da Glória & 877359 \\
\hline 1096 & Rodrigues, Maria Lélia O. F. & 843447 \\
\hline 1097 & Rodrigues, Rute Imanishi & 984357 \\
\hline 1098 & Rolim, Cássio Frederico C. & 396226 \\
\hline 1099 & Roma, Júlio César & 630702 \\
\hline 1100 & Romano, Ricardo & 476379 \\
\hline 1101 & Romminger, Alfredo Eric & 866952 \\
\hline 1102 & Roriz, João Henrique Ribeiro & 687183 \\
\hline 1103 & Rosa, Marco Antonio & 228286 \\
\hline 1104 & Rosalém, Andrezza & 752630 \\
\hline 1105 & Rosenberg, Gerson & 180332 \\
\hline 1106 & Rossi Jr., José Luiz & 451276 \\
\hline 1107 & Rossi, José W. & 247255 \\
\hline 1108 & Rossi, Pedro & 683701 \\
\hline 1109 & Rubens, Mario & 427869 \\
\hline 1110 & Rue, Havard & 538765 \\
\hline 1111 & Ruitenbeek, Jack & 513710 \\
\hline 1112 & Ruiz, Ricardo Machado & 935837 \\
\hline 1113 & Sá, Edvaldo Batista de & 562465 \\
\hline
\end{tabular}




\begin{tabular}{|c|c|c|}
\hline 1114 & Saboia, João & 174154 \\
\hline 1115 & Saccaro Junior, Nilo Luiz & 679564 \\
\hline 1116 & Sachsida, Adolfo & 602864 \\
\hline 1117 & Sadeck, Francisco & 452425 \\
\hline 1118 & Safatle, Leandro Pinheiro & 867460 \\
\hline 1119 & Sakowski, Patrícia A. Morita & 425432 \\
\hline 1120 & Salerno, Mário Sérgio & 193060 \\
\hline 1121 & Salgado, Lucia Helena & 352712 \\
\hline 1122 & Salles, Elder Vieira & 810662 \\
\hline 1123 & Sambuichi, Regina Helena Rosa & 487930 \\
\hline 1124 & Sanchez Badin, Michelle Ratton & 619194 \\
\hline 1125 & Sánchez, Ricardo J. & 183722 \\
\hline 1126 & Sant'Anna, Ana Cláudia & 791295 \\
\hline 1127 & Santana, Carlos Henrique Vieira & 304521 \\
\hline 1128 & Santana, José Paranaguá de & 310540 \\
\hline 1129 & Santana, Ricardo Felix & 511993 \\
\hline 1130 & Santana, Synthia Kariny Silva de & 291079 \\
\hline 1131 & Sant'Anna, José Alex & 284594 \\
\hline 1132 & Sant'Anna, Maristela & 587221 \\
\hline 1133 & Santiago, Priscila Braga & 277714 \\
\hline 1134 & Santos, Adelaide Figueiredo dos & 366259 \\
\hline 1135 & Santos, Angela Moulin S. Penalva & 265761 \\
\hline 1136 & Santos, Carlos Eduardo Meyer dos & 924722 \\
\hline 1137 & Santos, Carolina Fernandes dos & 464784 \\
\hline 1138 & Santos, Charley F. Velloso dos & 927273 \\
\hline 1139 & Santos, Cláudio Hamilton M. dos & 636334 \\
\hline 1140 & Santos, Daniel Domingues & 984582 \\
\hline 1141 & Santos, Diana Leite Nunes dos & 220709 \\
\hline 1142 & Santos, Eleonora & 430909 \\
\hline 1143 & Santos, Fabiano & 115097 \\
\hline 1144 & Santos, Fausto Pereira dos & 649067 \\
\hline 1145 & Santos, Francisco Eduardo de Luna Almeida & 282172 \\
\hline 1146 & Santos, Gesmar Rosa dos & 835612 \\
\hline 1147 & Santos, Iury R. & 343040 \\
\hline 1148 & Santos, José Carlos dos & 107316 \\
\hline 1149 & Santos, Manoel Leonardo & 279875 \\
\hline 1150 & Santos, Márcia Figueira de A. dos & 943325 \\
\hline 1151 & Santos, Maria Paula Gomes dos & 283730 \\
\hline 1152 & Santos, Marília de Barros & 285512 \\
\hline 1153 & Santos, Paula Xavier dos & 181043 \\
\hline 1154 & Saretta, Cássia Barbosa & 528426 \\
\hline 1155 & Sarmento, Viviane & 672502 \\
\hline 1156 & Gutierrez, Maria Bernadete & 587143 \\
\hline
\end{tabular}




\begin{tabular}{|c|c|c|}
\hline 1157 & Sarti, Fernando & 507554 \\
\hline 1158 & Sato, Ademar K. & 155022 \\
\hline 1159 & Sátyro, Natália & 918898 \\
\hline 1160 & Savedoff, William D. & 597311 \\
\hline 1161 & Sawaya Neto, Melchior & 873508 \\
\hline 1162 & Sawyer, Diana & 127181 \\
\hline 1163 & Sayago, Daiane Ely & 912030 \\
\hline 1164 & Schapiro, Mario G. & 269015 \\
\hline 1165 & Scharth, Marcel & 274518 \\
\hline 1166 & Schettini, Bernardo Patta & 108762 \\
\hline 1167 & Schettini, Daniela & 708133 \\
\hline 1168 & Schlittler, João Gabriel Felizardo & 648586 \\
\hline 1169 & Schmidt, Alexandra Mello & 513619 \\
\hline 1170 & Schmidt, Flávia de Holanda & 646994 \\
\hline 1171 & Schmitz, Guilherme de Oliveira & 248890 \\
\hline 1172 & Schneider, Ben Ross & 882646 \\
\hline 1173 & Schutte, Giorgio Romano & 954626 \\
\hline 1174 & Schwanen, Tim & 209716 \\
\hline 1175 & Schwarzer, Helmut & 327991 \\
\hline 1176 & Scofano, André & 163952 \\
\hline 1177 & Sedlacek, Guilherme Luis & 365844 \\
\hline 1178 & Sennes, Ricardo Ubiraci & 751174 \\
\hline 1179 & Serra, Bernardo & 903651 \\
\hline 1180 & Serra, Mozart Vitor & 916533 \\
\hline 1181 & Serra, Rodrigo Valente & 240208 \\
\hline 1182 & Serra, Rodrigo Valente & 760982 \\
\hline 1183 & Servo, Luciana M. Santos & 409000 \\
\hline 1184 & Shleifer, Andrei & 786256 \\
\hline 1185 & Shope, James Alan & 929624 \\
\hline 1186 & Sicsú, João & 201096 \\
\hline 1187 & Sidsamer, Samuel & 269148 \\
\hline 1188 & Silva Filho, Edison Benedito da & 894295 \\
\hline 1189 & Silva Filho, Luís Abel da & 630769 \\
\hline 1190 & Silva Júnior, Gílson Geraldino & 385137 \\
\hline 1191 & Silva, Alexandre Manoel Angelo da & 681599 \\
\hline 1192 & Silva, Alexandre Messa & 834593 \\
\hline 1193 & Silva, Almir Bittencourt da & 874555 \\
\hline 1194 & Silva, Ana Paula Moreira da & 994107 \\
\hline 1195 & Silva, André L. Carvalhal da & 268400 \\
\hline 1196 & Silva, Ângelo Henrique Lopes da & 277062 \\
\hline 1197 & Silva, Antonio Braz de Oliveira e & 991698 \\
\hline 1198 & Silva, Antonio Carlos Macedo e & 352207 \\
\hline 1199 & Silva, Beatriz A. & 278997 \\
\hline
\end{tabular}




\begin{tabular}{|c|c|c|}
\hline 1200 & Silva, Carlos Roberto Paiva da & 191292 \\
\hline 1201 & Silva, Danilo Cláudio da & 473242 \\
\hline 1202 & Silva, Diego Firmino Costa da & 235945 \\
\hline 1203 & Silva, Elaini Cristina Gonzaga da & 947367 \\
\hline 1204 & Silva, Enid Rocha Andrade da & 941310 \\
\hline 1205 & Silva, Fabio de Sá e & 498733 \\
\hline 1206 & Silva, Fernanda Rocha Gomes & 296457 \\
\hline 1207 & Silva, Fernando A. Rezende da & 377382 \\
\hline 1208 & Silva, Frederico A. Barbosa da & 342088 \\
\hline 1209 & Silva, Gabriela Drummond Marques da & 184643 \\
\hline 1210 & Silva, Hilton Leal & 110512 \\
\hline 1211 & Silva, Joelmir Rodrigues da & 466272 \\
\hline 1212 & Silva, Jorge Ferreira da & 964048 \\
\hline 1213 & Silva, José Cláudio F. da & 452296 \\
\hline 1214 & Silva, José Graziano da & 750281 \\
\hline 1215 & Silva, Leandro Valério & 482219 \\
\hline 1216 & Silva, Luciana Acioly da & 780249 \\
\hline 1217 & Silva, Luiz Carlos Eichenberg & 993597 \\
\hline 1218 & Silva, Márcio Francisco da & 976715 \\
\hline 1219 & Silva, Maria da Conceição & 961753 \\
\hline 1220 & Silva, Maria Luiza Falcão & 958123 \\
\hline 1221 & Silva, Marly Matias & 304958 \\
\hline 1222 & Silva, Monica Couto e & 767486 \\
\hline 1223 & Silva, Napoleão Luiz Costa da & 281011 \\
\hline 1224 & Silva, Neuma Benigno da & 796013 \\
\hline 1225 & Silva, Salomão Lipcovith Quadros da & 824168 \\
\hline 1226 & Silva, Sandro Pereira & 460596 \\
\hline 1227 & Silva, Simone Affonso da & 462316 \\
\hline 1228 & Silva, Tatiana Dias & 336731 \\
\hline 1229 & Silva, Wesley de Jesus & 399624 \\
\hline 1230 & Silveira Neto, Raul da Mota & 521334 \\
\hline 1231 & Silveira, Fernando Gaiger & 446305 \\
\hline 1232 & Silveira, José Maria da & 345724 \\
\hline 1233 & Silveira, Marcos Antonio Coutinho da & 986022 \\
\hline 1234 & Simões, Adriano & 349065 \\
\hline 1235 & Simões, Helenne Barbosa & 591735 \\
\hline 1236 & Simón, José & 945485 \\
\hline 1237 & Simonassi, Andrei G. & 514123 \\
\hline 1238 & Siqueira, Raíza & 909459 \\
\hline 1239 & Siqueira, Roberto & 539240 \\
\hline 1240 & Siqueira, Rozane Bezerra de & 952872 \\
\hline 1241 & Smith, Marc T. & 410637 \\
\hline 1242 & Smolka, Martim O. & 328680 \\
\hline
\end{tabular}




\begin{tabular}{|c|c|c|}
\hline 1243 & Soares, Ana Lúcia & 612161 \\
\hline 1244 & Soares, Fábio Veras & 210945 \\
\hline 1245 & Soares, Marcelo & 452595 \\
\hline 1246 & Soares, Mônica da Luz Carvalho & 400711 \\
\hline 1247 & Soares, Ricardo Pereira & 979287 \\
\hline 1248 & Soares, Rodrigo R. & 919269 \\
\hline 1249 & Soares, Rosa Maria Sales de Melo & 154705 \\
\hline 1250 & Soares, Sergei & 913703 \\
\hline 1251 & Sobral, Bruno Leonardo Barth & 394394 \\
\hline 1252 & Sobral, Carlos Cesar Bittencourt & 150514 \\
\hline 1253 & Sochaczewski, Antonio Claudio & 391304 \\
\hline 1254 & Sorj, Bila & 689598 \\
\hline 1255 & Sousa, Alexandre Gervásio de & 499257 \\
\hline 1256 & Sousa, Maria da Conceição Sampaio de & 277936 \\
\hline 1257 & Sousa, Rodrigo Abdalla Filgueiras de & 651682 \\
\hline 1258 & Sousa, Wagner & 104912 \\
\hline 1259 & Souto, Rodrigo Fontes & 802982 \\
\hline 1260 & Souto-Maior, Luis Augusto Pereira & 193685 \\
\hline 1261 & Souza Júnior, José Ronaldo de Castro & 683483 \\
\hline 1262 & Souza, Alberto de Mello e & 196720 \\
\hline 1263 & Souza, André de Mello e & 760607 \\
\hline 1264 & Souza, André Luis & 353389 \\
\hline 1265 & Souza, André Portela & 393346 \\
\hline 1266 & Souza, Carlos Frederico Braz de & 852055 \\
\hline 1267 & Souza, Celina & 753971 \\
\hline 1268 & Souza, Clóvis Henrique Leite de & 491334 \\
\hline 1269 & Souza, Darana & 886566 \\
\hline 1270 & Souza, Edgar Bastos de & 853446 \\
\hline 1271 & Souza, Frederico Hartmann de & 853728 \\
\hline 1272 & Souza, Gustavo Moreira de & 232265 \\
\hline 1273 & Souza, Marcelo Medeiros Coelho de & 554961 \\
\hline 1274 & Souza, Mirian Carvalho de & 421230 \\
\hline 1275 & Souza, Natália Ribeiro de & 151092 \\
\hline 1276 & Souza, Nathalia Almeida de & 474464 \\
\hline 1277 & Souza, Pedro H. G. F. de & 149055 \\
\hline 1278 & Souza, Reinaldo C. & 392761 \\
\hline 1279 & Spécie, Priscila & 608731 \\
\hline 1280 & Spolador, Humberto Francisco Silva & 172836 \\
\hline 1281 & Squeff, Flávia de Holanda Schmidt & 198725 \\
\hline 1282 & Squeff, Gabriel Coelho & 763534 \\
\hline 1283 & Squinca, Flávia & 275871 \\
\hline 1284 & Stivali, Matheus & 226570 \\
\hline 1285 & Studart, Rogério & 317682 \\
\hline
\end{tabular}




\begin{tabular}{|c|c|c|}
\hline 1286 & Sugahara, Tomie & 486149 \\
\hline 1287 & Sumi, Marcelo Colus & 368237 \\
\hline 1288 & Suzigan, Wilson & 976788 \\
\hline 1289 & Tafner, Paulo & 446668 \\
\hline 1290 & Tapia, Jorge Ruben Biton & 558104 \\
\hline 1291 & Tarragó, Daniel & 164690 \\
\hline 1292 & Tasquetto, Lucas da Silva & 382509 \\
\hline 1293 & Tavares, Sônia Maria Goes & 916824 \\
\hline 1294 & Teixeira, Ana Claudia Chaves & 985360 \\
\hline 1295 & Teixeira, Joanílio Rodolpho & 234372 \\
\hline 1296 & Teixeira, José Paulo & 994475 \\
\hline 1297 & Teixeira, Lucas Azeredo da Silva & 693766 \\
\hline 1298 & Teixeira, Luciana & 701064 \\
\hline 1299 & Teixeira, Marco Antonio C. & 663290 \\
\hline 1300 & Teixeira, Moema De Poli & 861341 \\
\hline 1301 & Teixeira, Rodrigo Alves & 384560 \\
\hline 1302 & Teles, Jorge Luiz & 378633 \\
\hline 1303 & Terra, José Cláudio Cyrineu & 563300 \\
\hline 1304 & Theodoro, Mário & 808647 \\
\hline 1305 & Thomas, Alban & 312318 \\
\hline 1306 & Thomé Neto, Cesar & 530723 \\
\hline 1307 & Thorstensen, Vera & 675697 \\
\hline 1308 & Tigre, Paulo Bastos & 876060 \\
\hline 1309 & Tironi, Luís Fernando & 695409 \\
\hline 1310 & Tito, Fabiana F. M. & 936536 \\
\hline 1311 & Toledo, Demétrio & 513496 \\
\hline 1312 & Tomas, Roberta & 403559 \\
\hline 1313 & Tomelin, Leon Faceira & 158905 \\
\hline 1314 & Tomich, Frederico Andrade & 223814 \\
\hline 1315 & Torres Filho, Ernani Teixeira & 121705 \\
\hline 1316 & Torres, Cristian A. C. & 260931 \\
\hline 1317 & Torres, Marcelo de Oliveira & 315488 \\
\hline 1318 & Tourinho, Octávio Augusto Fontes & 303934 \\
\hline 1319 & Tóvolli, Marina Haddad & 377088 \\
\hline 1320 & Tramontin, Raulino & 182585 \\
\hline 1321 & Trindade, Cláudia & 704200 \\
\hline 1322 & Turchi, Lenita Maria & 967643 \\
\hline 1323 & Turgeon, Mathieu & 915467 \\
\hline 1324 & Turolla, Frederico A. & 960176 \\
\hline 1325 & Tyler, William G. & 955961 \\
\hline 1326 & Ulyssea, Gabriel & 208566 \\
\hline 1327 & Urani, André & 569790 \\
\hline 1328 & Urban, Maria Lúcia de Paula & 646197 \\
\hline
\end{tabular}




\begin{tabular}{|c|c|c|}
\hline 1329 & Valadão, Lucília de Fátima Rocha & 563015 \\
\hline 1330 & Valadares, Alexandre Arbex & 870275 \\
\hline 1331 & Valli, Marcos & 199640 \\
\hline 1332 & Varandas, Simone & 230122 \\
\hline 1333 & Varella, Santiago & 593077 \\
\hline 1334 & Varizo, Cláudia & 305775 \\
\hline 1335 & Varsano, Ricardo & 702921 \\
\hline 1336 & Vasconcellos, Eduardo Alcântara de & 425435 \\
\hline 1337 & Vasconcellos, Pedro Gasparinetti & 919768 \\
\hline 1338 & Vasconcellos, Ronaldo & 759397 \\
\hline 1339 & Vasconcelos, Ana Maria Nogales & 996710 \\
\hline 1340 & Vasconcelos, Daniel de Santana & 786889 \\
\hline 1341 & Vasconcelos, José Romeu de & 778806 \\
\hline 1342 & Vasconcelos, Leonardo Fernandes S. & 204278 \\
\hline 1343 & Vasconcelos, Lucas Ferraz & 128182 \\
\hline 1344 & Vasconcelos, Ronaldo R. & 548772 \\
\hline 1345 & Vasquez, Brisne & 900013 \\
\hline 1346 & Vaz, Alexander & 197861 \\
\hline 1347 & Vaz, Fábio & 772169 \\
\hline 1348 & Veiga, José Eli da & 427922 \\
\hline 1349 & Veiga, Pedro da Motta & 828395 \\
\hline 1350 & Velazco, Tatiana & 195078 \\
\hline 1351 & Velez, Carlos Eduardo & 720092 \\
\hline 1352 & Velho, Eduardo & 217701 \\
\hline 1353 & Velloso, Ricardo Cicchelli & 910279 \\
\hline 1354 & Veloso, Fernando & 800570 \\
\hline 1355 & Verde, Carlos Monteiro Villa & 315526 \\
\hline 1356 & Vereda, Luciano & 681414 \\
\hline 1357 & Vergolino, José Raimundo & 479241 \\
\hline 1358 & Versiani, Flávio Rabelo & 296103 \\
\hline 1359 & Veszteg, Róbert & 188784 \\
\hline 1360 & Viacava, Francisco & 645079 \\
\hline 1361 & Viana, João Paulo & 503997 \\
\hline 1362 & Vianna, Ricardo L. L. & 547176 \\
\hline 1363 & Vianna, Salvador Werneck & 167673 \\
\hline 1364 & Vianna, Solon Magalhães & 972647 \\
\hline 1365 & Vieira Filho, José Eustáquio Ribeiro & 394116 \\
\hline 1366 & Vieira, Adriana Carvalho Pinto & 117679 \\
\hline 1367 & Vieira, Andrezza Rosalém & 392026 \\
\hline 1368 & Vieira, Carlos Alberto dos Santos & 628097 \\
\hline 1369 & Vieira, Maria Lucia & 386578 \\
\hline 1370 & Vieira, Nanah Sanches & 430347 \\
\hline 1371 & Vieira, Renato de Alcino & 263676 \\
\hline
\end{tabular}




\begin{tabular}{|c|c|c|}
\hline 1372 & Vieira, Roberta & 922121 \\
\hline 1373 & Vigevani, Tullo & 110319 \\
\hline 1374 & Villa Verde, Carlos Monteiro & 713283 \\
\hline 1375 & Villa, Simone Barbosa & 227797 \\
\hline 1376 & Villela, André & 447081 \\
\hline 1377 & Villela, Annibal V. & 394119 \\
\hline 1378 & Villela, Luiz A. & 411245 \\
\hline 1379 & Villela, Renato & 287240 \\
\hline 1380 & Viotti, Eduardo Baumgratz & 794488 \\
\hline 1381 & Viotti, Renato Baumgratz & 183410 \\
\hline 1382 & Vishny, Robert W. & 214803 \\
\hline 1383 & Vitale, Denise & 775913 \\
\hline 1384 & Volkoff, Serge & 979950 \\
\hline 1385 & Von Doellinger, Carlos & 464711 \\
\hline 1386 & Vonbun, Christian & 151460 \\
\hline 1387 & Waddington, Sérgio da Cruz & 117021 \\
\hline 1388 & Wang, Hyoung G. & 205411 \\
\hline 1389 & Waniez, Philippe & 899567 \\
\hline 1390 & Wavruk, Paulo & 493244 \\
\hline 1391 & Wexler, Sérgio & 839887 \\
\hline 1392 & Whitcomb, John B & 703903 \\
\hline 1393 & Willmore, Larry N. & 143598 \\
\hline 1394 & Wirbiski, Sérgio & 755649 \\
\hline 1395 & Wunder, Sven & 792672 \\
\hline 1396 & Xavier Junior, Carlos Eduardo Ramos & 738552 \\
\hline 1397 & Xavier, Antonio Carlos da R. & 278902 \\
\hline 1398 & Yannick, Kolai Zagbai Joel & 675027 \\
\hline 1399 & Yoshino, Joe Akira & 279457 \\
\hline 1400 & Young, Carlos Eduardo Frickmann & 615690 \\
\hline 1401 & Zackseski, Nelson Fernando & 353643 \\
\hline 1402 & Zaeyen, Adriana & 939878 \\
\hline 1403 & Zamboni, Roberto Aricó & 493322 \\
\hline 1404 & Zeidan, Rodrigo M. & 273786 \\
\hline 1405 & Zepeda, Eduardo & 539967 \\
\hline 1406 & Zockun, Maria Helena & 252061 \\
\hline 1407 & Zucoloto, Graziela Ferrero & 215437 \\
\hline 1408 & Zylberstajn, Eduardo & 322294 \\
\hline 1409 & Zylberstajn, Hélio & 650995 \\
\hline
\end{tabular}


APÊNDICE 2: BLOCOS DO PERÍODO: 1985 a 1994.

\begin{tabular}{|c|c|c|c|c|c|c|c|}
\hline Blocos & & & & & & & \\
\hline 1 & 884139 & 923507 & & & & & \\
\hline 2 & 923507 & 948248 & & & & & \\
\hline 3 & 100930 & 948248 & & & & & \\
\hline 4 & 137526 & 228253 & & & & & \\
\hline 5 & 228253 & 519233 & & & & & \\
\hline 6 & 155022 & 695409 & & & & & \\
\hline 7 & 103781 & 278902 & & & & & \\
\hline 8 & 278902 & 695409 & & & & & \\
\hline 9 & 364655 & 695409 & & & & & \\
\hline 10 & 481457 & 695409 & & & & & \\
\hline 11 & 484872 & 695409 & & & & & \\
\hline 12 & 695409 & 972647 & & & & & \\
\hline 13 & 695409 & 976649 & & & & & \\
\hline 14 & 695409 & 993597 & & & & & \\
\hline 15 & 577095 & 695409 & & & & & \\
\hline 16 & 228253 & 723859 & & & & & \\
\hline 17 & 228253 & 758766 & & & & & \\
\hline 18 & 228253 & 888415 & & & & & \\
\hline 19 & 101448 & 228253 & 577095 & 726588 & & & \\
\hline 20 & 110830 & 647430 & & & & & \\
\hline 21 & 113229 & 375681 & & & & & \\
\hline 22 & 119871 & 288536 & & & & & \\
\hline 23 & 143598 & 757056 & & & & & \\
\hline 24 & 247255 & 269148 & & & & & \\
\hline 25 & 247255 & 488071 & & & & & \\
\hline 26 & 247255 & 587221 & & & & & \\
\hline 27 & 379562 & 605962 & & & & & \\
\hline 28 & 172339 & 392761 & & & & & \\
\hline 29 & 247255 & 895768 & & & & & \\
\hline 30 & 247255 & 961753 & & & & & \\
\hline 31 & 709498 & 757056 & & & & & \\
\hline 32 & 732623 & 757056 & & & & & \\
\hline 33 & 368412 & 987234 & & & & & \\
\hline 34 & 288536 & 391402 & & & & & \\
\hline 35 & 476379 & 656920 & & & & & \\
\hline 36 & 288536 & 476379 & & & & & \\
\hline 37 & 288536 & 478824 & & & & & \\
\hline 38 & 288536 & 882646 & & & & & \\
\hline 39 & 410898 & 987037 & & & & & \\
\hline 40 & 416680 & 987037 & & & & & \\
\hline 41 & 475755 & 987037 & & & & & \\
\hline 42 & 748836 & 987037 & & & & & \\
\hline 43 & 116674 & 569790 & & & & & \\
\hline 44 & 127181 & 244208 & & & & & \\
\hline 45 & 565373 & 793415 & & & & & \\
\hline 46 & 195078 & 244208 & & & & & \\
\hline 47 & 277323 & 606897 & & & & & \\
\hline 48 & 277323 & 968635 & & & & & \\
\hline 49 & 277323 & 572717 & 981814 & & & & \\
\hline 50 & 469115 & 572717 & & & & & \\
\hline 51 & 524828 & 612161 & & & & & \\
\hline 52 & 230122 & 244208 & 365844 & 430909 & 524828 & 572717 & 752901 \\
\hline 53 & 244208 & 405531 & & & & & \\
\hline 54 & 244208 & 507257 & & & & & \\
\hline 55 & 244208 & 655768 & & & & & \\
\hline 56 & 244208 & 704200 & & & & & \\
\hline
\end{tabular}




\begin{tabular}{|c|c|c|c|c|c|c|c|c|c|c|c|c|c|}
\hline 57 & 244208 & 845944 & & & & & & & & & & & \\
\hline 58 & 244208 & 929624 & & & & & & & & & & & \\
\hline 59 & 173034 & 231748 & 244208 & 569790 & 793415 & 908813 & 962477 & & & & & & \\
\hline 60 & 459972 & 569790 & & & & & & & & & & & \\
\hline 61 & 569790 & 858299 & & & & & & & & & & & \\
\hline 62 & 857339 & 858299 & & & & & & & & & & & \\
\hline 63 & 278997 & 377382 & & & & & & & & & & & \\
\hline 64 & 278997 & 804408 & & & & & & & & & & & \\
\hline 65 & 287533 & 411245 & 804408 & & & & & & & & & & \\
\hline 66 & 502447 & 804408 & & & & & & & & & & & \\
\hline 67 & 702921 & 804408 & & & & & & & & & & & \\
\hline 68 & 804408 & 949753 & & & & & & & & & & & \\
\hline 69 & 804408 & 976110 & & & & & & & & & & & \\
\hline 70 & 520744 & 976110 & & & & & & & & & & & \\
\hline 71 & 113229 & 172339 & 247255 & 288536 & 368412 & 520744 & 559786 & 599193 & 605962 & 648083 & 757056 & 858299 & 987037 \\
\hline
\end{tabular}

\begin{tabular}{|l|l|l|}
\hline 72 & 113229 & 893954 \\
\hline 73 & 116298 & 411859 \\
\hline 74 & 116937 & 419447 \\
\hline 75 & 187768 & 936101 \\
\hline 76 & 116937 & 936101 \\
\hline 77 & 312015 & 827203 \\
\hline 78 & 584283 & 827203 \\
\hline 79 & 741482 & 827203 \\
\hline 80 & 827203 & 839887 \\
\hline 81 & 117719 & 827203 \\
\hline 82 & 335764 & 589197 \\
\hline 83 & 125561 & 589197 \\
\hline 84 & 135051 & 906439 \\
\hline 85 & 249523 & 650015 \\
\hline 86 & 141716 & 249523 \\
\hline 87 & 192416 & 870383 \\
\hline 88 & 193060 & 695729 \\
\hline 89 & 265761 & 873256 \\
\hline 90 & 404800 & 873256 \\
\hline 91 & 873256 & 927273 \\
\hline 92 & 201056 & 873256 \\
\hline 93 & 273319 & 786256 \\
\hline 94 & 214803 & 273319 \\
\hline 95 & 863346 & 916824 \\
\hline 96 & 282432 & 863346 \\
\hline 97 & 377900 & 467337 \\
\hline 98 & 415392 & 467337 \\
\hline 99 & 467337 & 478780 \\
\hline 100 & 467337 & 553089 \\
\hline 101 & 467337 & 610369 \\
\hline 102 & 467337 & 615690 \\
\hline 103 & 298090 & 467337 \\
\hline 104 & 303934 & 547176 \\
\hline 105 & 365708 & 459631 \\
\hline 106 & 374265 & 909273 \\
\hline 107 & 379457 & 497562 \\
\hline 108 & 379457 & 704026 \\
\hline 109 & 431669 & 478956 \\
\hline 110 & 558104 & 600058 \\
\hline 111 & 460847 & 600058 \\
\hline 112 & 557261 & 713283 \\
\hline 113 & 562669 & 813373 \\
\hline 114 & 569931 & 757745 \\
\hline 115 & 910279 & 993981 \\
\hline & & \\
\hline
\end{tabular}


APÊNDICE 3: BLOCOS DO PERÍODO: 1995 a 2010

\begin{tabular}{|c|c|c|c|c|c|c|c|c|}
\hline Blocos & & & & & Blocos & & & \\
\hline 1 & 158658 & 228253 & & & 51 & 207776 & 946122 & \\
\hline 2 & 228253 & 328310 & & & 52 & 424027 & 858051 & \\
\hline 3 & 228253 & 688349 & & & 53 & 451276 & 486127 & \\
\hline 4 & 151984 & 758766 & & & 54 & 188131 & 572717 & \\
\hline 5 & 486513 & 758766 & & & 55 & 286833 & 572717 & \\
\hline 6 & 175898 & 605962 & & & 56 & 288536 & 882646 & \\
\hline 7 & 253796 & 605962 & & & 57 & 288536 & 572717 & \\
\hline 8 & 293427 & 605962 & & & 58 & 572717 & 736816 & \\
\hline 9 & 644032 & 900013 & & & 59 & 572717 & 801358 & \\
\hline 10 & 605962 & 644032 & & & 60 & 572717 & 828395 & \\
\hline 11 & 113844 & 231781 & & & 61 & 572717 & 964358 & \\
\hline 12 & 113844 & 145459 & 291479 & & 62 & 113726 & 572717 & \\
\hline 13 & 184130 & 277323 & & & 63 & 113726 & 702921 & \\
\hline 14 & 186251 & 277323 & & & 64 & 271640 & 702921 & \\
\hline 15 & 538765 & 854889 & & & 65 & 169397 & 374265 & \\
\hline 16 & 102305 & 490550 & & & 66 & 368412 & 406609 & \\
\hline 17 & 198606 & 919857 & & & 67 & 374265 & 379844 & \\
\hline 18 & 137573 & 244208 & & & 68 & 374265 & 425888 & \\
\hline 19 & 163952 & 244208 & & & 69 & 374265 & 441794 & \\
\hline 20 & 191086 & 841791 & & & 70 & 374265 & 631962 & \\
\hline 21 & 123188 & 270937 & & & 71 & 374265 & 689598 & \\
\hline 22 & 555177 & 742671 & & & 72 & 374265 & 749376 & \\
\hline 23 & 419447 & 565373 & & & 73 & 374265 & 767486 & \\
\hline 24 & 629855 & 742671 & & & 74 & 374265 & 909273 & \\
\hline 25 & 283257 & 780249 & & & 75 & 374265 & 925456 & \\
\hline 26 & 742671 & 953299 & & & 76 & 374265 & 948609 & \\
\hline 27 & 102965 & 524828 & & & 77 & 413271 & 502447 & \\
\hline 28 & 373615 & 524828 & & & 78 & 502447 & 644081 & 702921 \\
\hline 29 & 386578 & 524828 & & & 79 & 421131 & 515857 & \\
\hline 30 & 524828 & 579171 & & & 80 & 184217 & 720340 & \\
\hline 31 & 524828 & 752901 & & & 81 & 198012 & 720340 & \\
\hline 32 & 116413 & 714134 & & & 82 & 206032 & 588580 & \\
\hline 33 & 275871 & 714134 & & & 83 & 107917 & 640265 & \\
\hline 34 & 460521 & 714134 & & & 84 & 351854 & 373711 & \\
\hline 35 & 301347 & 450368 & & & 85 & 373711 & 467570 & \\
\hline 36 & 452987 & 601830 & & & 86 & 282529 & 922121 & \\
\hline 37 & 498214 & 520744 & & & 87 & 112468 & 192945 & \\
\hline 38 & 498214 & 584574 & & & 88 & 130284 & 192945 & \\
\hline 39 & 222079 & 602864 & & & 89 & 192945 & 227503 & \\
\hline 40 & 255976 & 357202 & & & 90 & 192945 & 265396 & \\
\hline 41 & 255976 & 631238 & & & 91 & 111675 & 446305 & \\
\hline 42 & 209132 & 255976 & 316462 & 770131 & 92 & 226329 & 366259 & \\
\hline 43 & 212868 & 770131 & & & 93 & 226329 & 686155 & \\
\hline 44 & 272068 & 770131 & & & 94 & 424769 & 644623 & \\
\hline 45 & 376251 & 607687 & 888682 & & 95 & 427755 & 644623 & \\
\hline 46 & 157074 & 435626 & & & 96 & 228317 & 427755 & \\
\hline 47 & 157074 & 226570 & & & 97 & 228317 & 747496 & \\
\hline 48 & 107316 & 946122 & & & 98 & 228317 & 834593 & \\
\hline 49 & 282124 & 841404 & & & 99 & 600106 & 834593 & \\
\hline 50 & 628097 & 841404 & & & 100 & 649954 & 834593 & \\
\hline
\end{tabular}




\begin{tabular}{|c|c|c|c|c|c|c|c|c|c|c|}
\hline Blocos & & & Blocos & & & & Blocos & & & \\
\hline 101 & 226329 & 877359 & 151 & 778806 & 813190 & & 201 & 467337 & 912030 & \\
\hline 102 & 188677 & 244282 & 152 & 778806 & 874555 & & 202 & 587143 & 950403 & \\
\hline 103 & 244282 & 704283 & 153 & 514123 & 943547 & & 203 & 258152 & 287240 & \\
\hline 104 & 244282 & 405878 & 154 & 855367 & 937469 & & 204 & 258152 & 830622 & \\
\hline 105 & 405878 & 764925 & 155 & 345724 & 696589 & & 205 & 365708 & 899567 & \\
\hline 106 & 515892 & 764925 & 156 & 345724 & 623856 & & 206 & 365708 & 988462 & \\
\hline 107 & 543037 & 764925 & 157 & 487293 & 703946 & & 207 & 365708 & 830622 & \\
\hline 108 & 676346 & 764925 & 158 & 766189 & 860020 & & 208 & 464784 & 551725 & \\
\hline 109 & 764925 & 887826 & 159 & 297500 & 597734 & & 209 & 551725 & 699035 & \\
\hline 110 & 245783 & 487183 & 160 & 432286 & 597734 & & 210 & 551725 & 921245 & \\
\hline 111 & 245783 & 446305 & 161 & 452425 & 597734 & & 211 & 507554 & 875506 & \\
\hline 112 & 278175 & 446305 & 162 & 509591 & 597734 & & 212 & 875506 & 886230 & \\
\hline 113 & 466272 & 481457 & 163 & 591735 & 597734 & & 213 & 830622 & 902912 & \\
\hline 114 & 481457 & 609812 & 164 & 597734 & 723561 & & 214 & 711730 & 913703 & \\
\hline 115 & 310540 & 766189 & 165 & 597734 & 735294 & & 215 & 867154 & 913703 & \\
\hline 116 & 342088 & 353389 & 166 & 240637 & 533109 & & 216 & 446305 & 938968 & \\
\hline 117 & 555519 & 735783 & 167 & 240637 & 786357 & & 217 & 730987 & 893050 & \\
\hline 118 & 140563 & 781167 & 168 & 240637 & 757305 & & 218 & 192945 & 595101 & \\
\hline 119 & 112538 & 538966 & 169 & 459319 & 986373 & & 219 & 192945 & 740107 & \\
\hline 120 & 205411 & 538966 & 170 & 526313 & 986373 & & 220 & 192945 & 784011 & 897731 \\
\hline 121 & 240387 & 538966 & 171 & 770954 & 986373 & & 221 & 423465 & 590710 & \\
\hline 122 & 167362 & 443261 & 172 & 924861 & 986373 & & 222 & 590710 & 765456 & \\
\hline 123 & 439292 & 443261 & 173 & 527648 & 913703 & & 223 & 235857 & 905684 & \\
\hline 124 & 315243 & 443261 & 174 & 539967 & 913703 & & 224 & 235857 & 913678 & \\
\hline 125 & 419624 & 538966 & 175 & 108762 & 174769 & & 225 & 521334 & 681599 & \\
\hline 126 & 309561 & 927278 & 176 & 174769 & 393984 & & 226 & 456499 & 881065 & \\
\hline 127 & 538966 & 964148 & 177 & 174769 & 581109 & & 227 & 850960 & 881065 & \\
\hline 128 & 392223 & 967301 & 178 & 174769 & 636334 & & 228 & 249536 & 720340 & \\
\hline 129 & 204278 & 670853 & 179 & 306956 & 636334 & & 229 & 351514 & 720340 & \\
\hline 130 & 553074 & 670853 & 180 & 169642 & 950403 & & 230 & 460840 & 720340 & \\
\hline 131 & 670853 & 866952 & 181 & 440316 & 950403 & & 231 & 626042 & 720340 & \\
\hline 132 & 695409 & 709240 & 182 & 163032 & 467337 & & 232 & 720340 & 801827 & \\
\hline 133 & 317682 & 644889 & 183 & 224591 & 467337 & & 233 & 720340 & 852266 & \\
\hline 134 & 317682 & 690817 & 184 & 264364 & 467337 & & 234 & 702921 & 934801 & \\
\hline 135 & 273786 & 709498 & 185 & 338820 & 467337 & & 235 & 540115 & 946030 & \\
\hline 136 & 597311 & 709498 & 186 & 381198 & 467337 & & 236 & 681414 & 946030 & \\
\hline 137 & 597311 & 690817 & 187 & 413809 & 467337 & 746710 & 237 & 946030 & 953576 & \\
\hline 138 & 690817 & 720142 & 188 & 415392 & 467337 & & 238 & 273477 & 987037 & \\
\hline 139 & 690817 & 812266 & 189 & 191642 & 438227 & & 239 & 322294 & 987037 & \\
\hline 140 & 437260 & 690817 & 190 & 312318 & 438227 & & 240 & 393346 & 987037 & \\
\hline 141 & 788948 & 906431 & 191 & 438227 & 467337 & & 241 & 439870 & 987037 & \\
\hline 142 & 207627 & 220220 & 192 & 467337 & 513710 & & 242 & 475755 & 987037 & \\
\hline 143 & 136286 & 841624 & 193 & 467337 & 527376 & & 243 & 477637 & 987037 & \\
\hline 144 & 426038 & 855367 & 194 & 110512 & 606897 & & 244 & 650995 & 987037 & \\
\hline 145 & 673605 & 855367 & 195 & 314726 & 606897 & & 245 & 659257 & 987037 & \\
\hline 146 & 417343 & 778806 & 196 & 467337 & 606897 & & 246 & 447081 & 800570 & \\
\hline 147 & 420415 & 778806 & 197 & 615690 & 739608 & & 247 & 800570 & 987037 & \\
\hline 148 & 463216 & 778806 & 198 & 467337 & 615690 & & 248 & 987037 & 998060 & \\
\hline 149 & 606476 & 665704 & 199 & 467337 & 677832 & & 249 & 320941 & 683483 & \\
\hline 150 & 778806 & 802041 & 200 & 467337 & 750768 & & 250 & 145551 & 327991 & \\
\hline
\end{tabular}




\begin{tabular}{|c|c|c|c|c|c|c|c|c|c|c|c|}
\hline Blocos & & & & Blocos & & & Blocos & & & & \\
\hline 251 & 296755 & 327991 & & 301 & 244208 & 503428 & 351 & 569541 & 824168 & & \\
\hline 252 & 327991 & 752253 & & 302 & 244208 & 548772 & 352 & 277323 & 319656 & & \\
\hline 253 & 327991 & 785760 & & 303 & 244208 & 752630 & 353 & 277323 & 350210 & & \\
\hline 254 & 171257 & 941310 & & 304 & 244208 & 899139 & 354 & 277323 & 362728 & & \\
\hline 255 & 327991 & 941310 & & 305 & 244208 & 954914 & 355 & 277323 & 461216 & & \\
\hline 256 & 327991 & 763587 & 890044 & 306 & 254477 & 934480 & 356 & 277323 & 543683 & & \\
\hline 257 & 337449 & 890044 & & 307 & 397922 & 934480 & 357 & 150514 & 939878 & & \\
\hline 258 & 224200 & 667182 & & 308 & 448201 & 934480 & 358 & 561738 & 939878 & & \\
\hline 259 & 552764 & 750281 & & 309 & 849022 & 934480 & 359 & 563015 & 991698 & & \\
\hline 260 & 687825 & 750281 & & 310 & 730581 & 919857 & 360 & 570846 & 756857 & 939878 & 991698 \\
\hline 261 & 771648 & 890044 & & 311 & 526397 & 958123 & 361 & 277323 & 570846 & & \\
\hline 262 & 869302 & 890044 & & 312 & 526397 & 966730 & 362 & 277323 & 684554 & & \\
\hline 263 & 154677 & 739639 & & 313 & 282172 & 808378 & 363 & 277323 & 845830 & & \\
\hline 264 & 199640 & 398798 & & 314 & 106525 & 290924 & 364 & 277323 & 962942 & & \\
\hline 265 & 303934 & 398798 & & 315 & 106525 & 353327 & 365 & 145459 & 307229 & & \\
\hline 266 & 277936 & 426824 & & 316 & 106525 & 511167 & 366 & 145459 & 438296 & & \\
\hline 267 & 234372 & 426824 & & 317 & 219371 & 239355 & 367 & 145459 & 510736 & & \\
\hline 268 & 295009 & 602864 & & 318 & 219879 & 239355 & 368 & 145459 & 830752 & & \\
\hline 269 & 601830 & 614896 & & 319 & 258623 & 372709 & 369 & 145459 & 916939 & & \\
\hline 270 & 301347 & 653429 & & 320 & 362205 & 672205 & 370 & 159550 & 858299 & & \\
\hline 271 & 291858 & 916533 & & 321 & 672205 & 763534 & 371 & 202261 & 858299 & & \\
\hline 272 & 297879 & 916533 & & 322 & 372709 & 672205 & 372 & 350989 & 858299 & & \\
\hline 273 & 329285 & 916533 & & 323 & 239355 & 372709 & 373 & 559786 & 858299 & & \\
\hline 274 & 410637 & 916533 & & 324 & 239355 & 735452 & 374 & 574991 & 858299 & & \\
\hline 275 & 543960 & 916533 & & 325 & 239355 & 347180 & 375 & 832450 & 858299 & & \\
\hline 276 & 578999 & 916533 & & 326 & 490550 & 810820 & 376 & 438704 & 972396 & & \\
\hline 277 & 796925 & 997035 & & 327 & 384305 & 936101 & 377 & 427922 & 515289 & & \\
\hline 278 & 796925 & 916533 & & 328 & 425432 & 936101 & 378 & 515289 & 972396 & & \\
\hline 279 & 547100 & 860164 & & 329 & 577811 & 936101 & 379 & 682283 & 972396 & & \\
\hline 280 & 860164 & 877447 & & 330 & 752165 & 936101 & 380 & 696729 & 972396 & & \\
\hline 281 & 714134 & 860164 & & 331 & 425435 & 936101 & 381 & 735341 & 972396 & & \\
\hline 282 & 714134 & 873508 & & 332 & 425435 & 565446 & 382 & 972396 & 996710 & & \\
\hline 283 & 714134 & 933129 & & 333 & 294073 & 565446 & 383 & Final & & & \\
\hline 284 & 695567 & 724605 & & 334 & 294073 & 557261 & 384 & 101448 & 421230 & & \\
\hline 285 & 778764 & 841791 & & 335 & 315526 & 557261 & 385 & 101448 & 473242 & & \\
\hline 286 & 211675 & 244208 & & 336 & 493028 & 557261 & 386 & 101448 & 577095 & & \\
\hline 287 & 213498 & 244208 & & 337 & 557261 & 572955 & 387 & 101448 & 762162 & & \\
\hline 288 & 244208 & 347804 & & 338 & 557261 & 713283 & 388 & 101448 & 785930 & & \\
\hline 289 & 244208 & 353643 & 843447 & 339 & 557261 & 789648 & 389 & 101448 & 786627 & & \\
\hline 290 & 403559 & 454931 & & 340 & 254817 & 815929 & 390 & 101448 & 810662 & & \\
\hline 291 & 194293 & 274518 & & 341 & 557261 & 815929 & 391 & 101448 & 861341 & & \\
\hline 292 & 403577 & 606261 & & 342 & 579356 & 952177 & 392 & 101448 & 874167 & & \\
\hline 293 & 194293 & 403577 & & 343 & 115908 & 878753 & 393 & 101448 & 922413 & & \\
\hline 294 & 194293 & 952872 & & 344 & 119196 & 569541 & 394 & 101448 & 939916 & & \\
\hline 295 & 194293 & 790379 & & 345 & 265761 & 569541 & 395 & 105210 & 328930 & & \\
\hline 296 & 403559 & 790379 & & 346 & 569541 & 627788 & 396 & 161059 & 667688 & & \\
\hline 297 & 244208 & 403559 & & 347 & 569541 & 663543 & 397 & 378633 & 667688 & & \\
\hline 298 & 244208 & 452595 & & 348 & 637995 & 703903 & 398 & 396091 & 667688 & & \\
\hline 299 & 244208 & 475610 & & 349 & 569541 & 703903 & 399 & 439819 & 667688 & & \\
\hline 300 & 244208 & 476919 & & 350 & 569541 & 775437 & 400 & 667688 & 688185 & & \\
\hline
\end{tabular}




\begin{tabular}{|c|c|c|c|c|c|c|c|}
\hline Blocos & & & & & Blocos & & \\
\hline 401 & 105210 & 667688 & & & 451 & 451184 & 843320 \\
\hline 402 & 109151 & 808777 & & & 452 & 493244 & 793748 \\
\hline 403 & 113469 & 413843 & & & 453 & 646197 & 793748 \\
\hline 404 & 113853 & 925842 & & & 454 & 755649 & 793748 \\
\hline 405 & 886566 & 945083 & & & 455 & 478338 & 793748 \\
\hline 406 & 114453 & 945083 & & & 456 & 482414 & 566319 \\
\hline 407 & 116298 & 411859 & & & 457 & 482414 & 659353 \\
\hline 408 & 119871 & 852055 & & & 458 & 491662 & 911642 \\
\hline 409 & 117021 & 119871 & & & 459 & 650015 & 909456 \\
\hline 410 & 151932 & 463447 & & & 460 & 493322 & 909456 \\
\hline 411 & 180332 & 976649 & & & 461 & 496283 & 848795 \\
\hline 412 & 278902 & 744353 & 879460 & 976649 & 462 & 549265 & 723107 \\
\hline 413 & 497220 & 976649 & & & 463 & 549265 & 786889 \\
\hline 414 & 563300 & 976649 & & & 464 & 924722 & 986022 \\
\hline 415 & 976649 & 984658 & & & 465 & 555629 & 986022 \\
\hline 416 & 162224 & 976649 & & & 466 & 775913 & 947367 \\
\hline 417 & 292242 & 808647 & & & 467 & 608731 & 947367 \\
\hline 418 & 594995 & 808647 & & & 468 & 720845 & 803176 \\
\hline 419 & 163028 & 808647 & & & 469 & 760607 & 965527 \\
\hline 420 & 174154 & 629656 & & & 470 & 760607 & 977072 \\
\hline 421 & 337125 & 449152 & & & 471 & 762224 & 936511 \\
\hline 422 & 449152 & 699443 & & & & & \\
\hline 423 & 449152 & 724393 & & & & & \\
\hline 424 & 449152 & 751174 & & & & & \\
\hline 425 & 449152 & 799683 & & & & & \\
\hline 426 & 449152 & 945485 & & & & & \\
\hline 427 & 204043 & 449152 & & & & & \\
\hline 428 & 261976 & 594283 & & & & & \\
\hline 429 & 205444 & 261976 & & & & & \\
\hline 430 & 591431 & 645079 & & & & & \\
\hline 431 & 591547 & 645079 & & & & & \\
\hline 432 & 226617 & 591547 & & & & & \\
\hline 433 & 415043 & 493802 & & & & & \\
\hline 434 & 229694 & 415043 & & & & & \\
\hline 435 & 249484 & 519435 & & & & & \\
\hline 436 & 268096 & 345773 & & & & & \\
\hline 437 & 268400 & 372860 & & & & & \\
\hline 438 & 269059 & 572819 & & & & & \\
\hline 439 & 281259 & 453729 & & & & & \\
\hline 440 & 281259 & 657142 & & & & & \\
\hline 441 & 319080 & 441139 & & & & & \\
\hline 442 & 352712 & 777236 & & & & & \\
\hline 443 & 394119 & 459600 & & & & & \\
\hline 444 & 394119 & 976788 & & & & & \\
\hline 445 & 510229 & 649410 & & & & & \\
\hline 446 & 396226 & 510229 & & & & & \\
\hline 447 & 401542 & 967643 & & & & & \\
\hline 448 & 421287 & 798915 & & & & & \\
\hline 449 & 425134 & 935492 & & & & & \\
\hline 450 & 586859 & 843320 & & & & & \\
\hline
\end{tabular}




\begin{tabular}{|c|c|c|c|c|c|c|c|c|c|c|}
\hline Blocos & & & & & & & & & & \\
\hline $\mathbf{3 8 3}$ & 101448 & 103308 & 106525 & 108214 & 115908 & 125659 & 129565 & 136286 & 145459 & 151092 \\
\hline & 154677 & 165155 & 167673 & 168696 & 172836 & 173034 & 175598 & 180840 & 188784 & 192416 \\
\hline & 192945 & 193060 & 201056 & 206032 & 208566 & 210212 & 210945 & 217701 & 220220 & 223814 \\
\hline & 226329 & 226570 & 228253 & 234372 & 235857 & 236551 & 240208 & 242135 & 244208 & 270937 \\
\hline & 272213 & 277323 & 281011 & 282172 & 285512 & 289128 & 301347 & 303934 & 304958 & 310500 \\
\hline & 314489 & 315243 & 317790 & 320941 & 342088 & 343384 & 345776 & 347180 & 353889 & 368412 \\
\hline & 373711 & 374265 & 375064 & 379562 & 404403 & 409000 & 424027 & 437260 & 446305 & 446668 \\
\hline & 451276 & 467337 & 479241 & 481457 & 486149 & 490550 & 493954 & 495566 & 498214 & 513619 \\
\hline & 515857 & 523567 & 524828 & 526397 & 527418 & 534938 & 535505 & 538966 & 539240 & 551725 \\
\hline & 555519 & 557261 & 565373 & 566812 & 569541 & 579356 & 590710 & 590939 & 593077 & 597734 \\
\hline & 601830 & 602864 & 605962 & 607687 & 614790 & 616379 & 623856 & 629693 & 630341 & 636334 \\
\hline & 637923 & 640265 & 665704 & 667182 & 670853 & 671089 & 675846 & 677661 & 681599 & 687825 \\
\hline & 690274 & 695409 & 695567 & 701064 & 702921 & 703946 & 714134 & 720092 & 720340 & 722125 \\
\hline & 730987 & 742671 & 757305 & 758766 & 759397 & 764925 & 766189 & 770131 & 771127 & 772169 \\
\hline & 778806 & 779107 & 780249 & 781167 & 788948 & 788978 & 801498 & 808588 & 812238 & 830622 \\
\hline & 834593 & 841404 & 841791 & 842392 & 854889 & 855367 & 858299 & 863644 & 867460 & 877046 \\
\hline & 880316 & 881065 & 886230 & 890044 & 913703 & 916533 & 918898 & 919857 & 922121 & 927278 \\
\hline & 927784 & 934480 & 938626 & 943325 & 943547 & 946030 & 946122 & 950403 & 955578 & 962477 \\
\hline & 967301 & 972396 & 972647 & 979287 & 984357 & 984582 & 986373 & 986849 & 987037 & 987058 \\
\hline
\end{tabular}

